UNIVERSIDADE DE SÃO PAULO

ESCOLA DE ARTES, CIÊNCIAS E HUMANIDADES

PROGRAMA DE PÓS-GRADUAÇÃO EM TÊXTIL E MODA

MARCIA CRISTINA SILVA

Análise da inflamabilidade de têxteis de uniformes de aeronautas

São Paulo

2018 


\section{Análise da inflamabilidade de têxteis de uniformes de aeronautas}

Dissertação apresentada à Escola de Artes, Ciências e Humanidades da Universidade de São Paulo para obtenção do título de Mestre em Ciências pelo Programa de Pós-graduação em Têxtil e Moda.

Versão corrigida contendo as alterações solicitadas pela comissão julgadora em dia de mês de ano. A versão original encontra-se em acervo reservado na Biblioteca da EACH/USP e na Biblioteca Digital de Teses e Dissertações da USP (BDTD), de acordo com a Resolução CoPGr 6018, de 13 de outubro de 2011.

Área de Concentração:

Materiais e Processos têxteis

Orientador:

Profa. Dra. Júlia Baruque Ramos

São Paulo 
Autorizo a reprodução e divulgação total ou parcial deste trabalho, por qualquer meio convencional ou eletrônico, para fins de estudo e pesquisa, desde que citada a fonte.

CATALOGAÇÃO-NA-PUBLICAÇÃO

(Universidade de São Paulo. Escola de Artes, Ciências e Humanidades. Biblioteca) CRB 8- 4936

Silva, Marcia Cristina

Análise da inflamabilidade de têxteis de uniformes de aeronautas / Marcia Cristina Silva ; orientadora, Júlia Baruque Ramos. - 2018 $213 \mathrm{f}$. : il

Dissertação (Mestrado em Ciências) - Programa de PósGraduação em Têxtil e Moda, Escola de Artes, Ciências e Humanidades, Universidade de São Paulo Versão corrigida

1. Tecidos (Indústria têxtil). 2. Uniformes - Análise físicoquímica. 3. Inflamabilidade. 4. Aeronautas. 5. Aviação. I.

Baruque-Ramos, Júlia, orient. II. Título.

CDD 22.ed. -. 677.02 
Nome: SILVA, Marcia Cristina

Título: Análise da inflamabilidade de têxteis de uniformes de aeronautas

Dissertação apresentada à Escola de Artes, Ciências e Humanidades da Universidade de São Paulo para obtenção do título de Mestre em Ciências do Programa de Pós-Graduação em Têxtil e Moda.

Aprovado em: 06 / 09 / 2018

Área de Concentração:

Materiais e Processos têxteis

\section{Banca Examinadora}

Profa. Dra. Júlia Baruque Ramos

Universidade de São Paulo. Escola de Artes, Ciências e Humanidades

Prof. Dr. Eduardo de Senzi Zancul

Universidade de São Paulo. Escola Politécnica

Prof. Dr. Marcelo Silva Oliveira

Universidade de São Paulo. Faculdade de Arquitetura e Urbanismo

Prof. Dr. Fernando Gasi

Universidade Federal do ABC 
Dedico este trabalho ao meu amado marido Rui Vagner Pereira dos Santos por toda ajuda, tornando a jornada mais suave. 


\section{Agradecimentos}

Ao meu marido, Rui Vagner Pereira dos Santos, cúmplice na minha vida, pelo apoio incondicional em todas as horas.

À minha filha, Ana Cristina Silva dos Santos, pelo desafio de ser mãe e pesquisadora.

À minha mãe, Dirce Previsto Silva, aos meus irmãos, sobrinhos, primos e amigos que, de diferentes maneiras, participaram incentivando e colaborando com a realização da minha pesquisa.

À Profa. Dra. Júlia Baruque Ramos, que com conhecimento e paciência me mostrou o caminho a ser trilhado.

Ao Prof. Dr. Raul Fangueiro e ao Engenheiro Joaquim Jorge Peixoto pela receptividade durante meu estágio na Universidade do Minho na cidade de Guimarães, Portugal.

Ao Prof. Dr. Marcelo Silva Oliveira pela confiança e grande ajuda na obtenção de material para a realização deste trabalho.

Ao Prof. Dr. Eduardo de Senzi Zancul pelas considerações feitas no exame de qualificação que contribuíram muito para o aprimoramento desta dissertação.

Ao Prof. Dr. Fernando Gasi, pela verificação da abordagem estatística.

Aos Professores: Dra. Francisca Dantas Mendes, Dra. Silgia Aparecida da Costa, Dra. Sirlene Maria da Costa, Dr. Antônio Takao Kanamaru, Dra. Isabel Cristina Italiano, Dr. Mauricio de Campos Araújo, Dr. Dib Karam Júnior pela contribuição na realização deste trabalho.

Às minhas alunas e aluno das oficinas da Universidade Aberta a Terceira Idade (UNATI), com quem compartilhei o que sabia e aprendi muito daquilo que não sabia.

À Bárbara Leonardi pela gentileza em realizar os testes de FTIR na empresa Golden Technology.

Aos funcionários da Escola de Artes, Ciências e Humanidades da Universidade de São Paulo por todo o apoio recebido para a realização do presente Mestrado.

Às colegas da USP: Kelly Cristina de Acêncio Kumagai, Gisele Brandão Kanda e Priscila Baracho, que deram ouvidos às minhas inquietações ainda na graduação. No mestrado tive a companhia de Mariana Laktim e Patrícia Muniz colaborando na caminhada e em especial a Alessandra Maria Giacomin pelas longas conversas e reflexões.

Agradeço também o apoio financeiro, através do processo no 2016/01331-9, Fundação de Amparo à Pesquisa do Estado de São Paulo (FAPESP). 
Vejo os outros

Todos estão tentando

E é tão certo quanto calor do fogo

Eu já não tenho escolha

E participo do seu jogo, participo.

(BARRETI; PRETO, 1988) 


\section{RESUMO}

SILVA, Marcia Cristina. Análise da inflamabilidade de têxteis de uniformes de aeronautas. 2018. 213 f. Dissertação (Mestrado em Ciências) - Escola de Artes, Ciências e Humanidades, Universidade de São Paulo, São Paulo, 2018. Versão corrigida.

As condições de inflamabilidade estabelecidas nas normas aeronáuticas aplicadas aos têxteis integrantes da cabine de passageiros do avião, não são requeridas para aplicação aos uniformes dos aeronautas. No entanto, uma vez que faz parte da função da tripulação, notadamente os comissários de voo, o combate de fogo a bordo, mesmo que esse tipo de acidente não seja frequente em relação à totalidade dos acidentes em geral desse setor, esse fato direcionou o presente estudo para conhecer os limites dos materiais têxteis dos uniformes dos aeronautas com relação à inflamabilidade. Deste modo, foram objetivos: determinar a inflamabilidade (velocidade de queima) de amostra de tecidos profissionais e de amostras de peças de uniformes de aeronautas; caracterizar os tecidos profissionais e os que constituem peças de uniformes de aeronautas, através de testes de: composição, gramatura, número de fio por trama e urdume, ligamento, espessura do tecido, diâmetro de fios, densidade linear e torção; calcular o diâmetro do fio e fator de cobertura e correlacionar os valores obtidos de inflamabilidade com os valores da caracterização dos tecidos e parâmetros calculados. Os experimentos foram realizados em três tecidos profissionais e em oito peças de uniformes de aeronautas de companhias diferentes, doadas para este estudo, além de entrevistas semiestruturadas e visita técnica. A interpretação dos resultados obtidos foi realizada com aplicação de testes de normalidade de dados, igualdade de variâncias, ANOVA, teste T e teste não paramétrico de Kruskall-Wallis. Os resultados encontrados no presente estudo não se enquadram nos limites preconizados pela FAR25 para que o material seja qualificado auto extinguível. O menor valor de inflamabilidade foi de $\mathbf{0 , 7 4 2} \pm 0,140(\mathrm{~cm} / \mathrm{s})$. Este resultado trata-se da média obtida da velocidade de queima das 10 amostras ensaiadas do tecido da peça P7 (calça masculina) na direção da trama. A composição

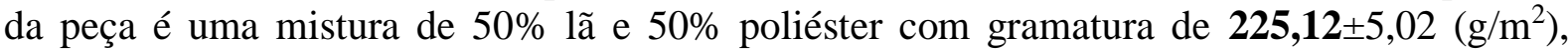
densidade linear do fio de $\mathbf{3 6 , 6 1} \pm 1,48$ (tex) e torção de $\mathbf{5 9 8 , 0 0 \pm 4 5 , 3 4 ( t o r c ̧ o ̃ e s ~} / \mathrm{m}$ ). O diâmetro do fio calculado pelo modelo de Peirce foi de $\mathbf{0 , 2 1 9} \mathrm{mm}$. O maior valor de inflamabilidade foi $\mathbf{3 , 6 9 8} \pm 1,806(\mathrm{~cm} / \mathrm{s})$. Este resultado trata-se da média obtida da velocidade de queima das 10 amostras ensaiadas do tecido da peça P5 (camisa masculina) na direção da trama. A composição da peça é uma mistura de $67 \%$ poliéster e $33 \%$ algodão com gramatura de $\mathbf{1 0 8 , 7 2} \pm 2,39\left(\mathrm{~g} / \mathrm{m}^{2}\right)$,

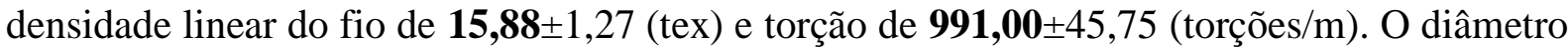
do fio calculado pelo modelo de Peirce foi de $\mathbf{0 , 1 4 8} \mathrm{mm}$. Influência da direção na velocidade de queima. A análise de variância com todos os fatores, não foi validada pela análise dos resíduos., entretanto a verificação da relação entre as variáveis explicativas "direção", "material" e "ligamento" com a variável resposta "velocidade de queima" realizada com o agrupamento por características físicas específicas, resultou em análises validadas por seus resíduos.Influência da "direção" na "velocidade de queima" para grupo "material 100\% CO, ligamento tela", a velocidade de queima é estatisticamente igual na direção de trama e urdume, grupo "material 100\% PES, ligamento sarja", a velocidade de queima é estatisticamente diferente, sendo menor na direção da trama, grupo "material 100\% PES, ligamento tela", a velocidade de queima é estatisticamente diferente, sendo menor na direção do urdume, grupo "material 67\% PES/33\% CO, ligamento sarja" e "material 67\% PES/33\% CO, ligamento tela", a velocidade de queima é estatisticamente igual na direção de trama e urdume e grupo "material $50 \% \mathrm{WO} / 50 \%$ PES, ligamento tela", a elocidade de queima é igual na direção de trama e urdume. Influência do "material" na "velocidade de queima": grupo "ligamento sarja, direção trama" a velocidade de queima é estatisticamente diferente, sendo menor para a composição 
algodão (100\% CO), grupo "ligamento sarja, direção urdume" a velocidade de queima é estatisticamente diferente, sendo menor para o material algodão $(\mathbf{1 0 0 \%} \mathbf{C O})$, grupo "ligamento tela,direção trama" a velocidade de queima é estatisticamente igual para os materiais $100 \%$ CO, 100\%PES, 67\%PES/33\% CO e 50\%WO/50\%PES, grupo " ligamento tela, direção urdume a velocidade de queima é estatisticamente igual para o material $67 \%$ PES/33\% CO. Assim sugestões para estudos futuros podem levar em conta construções mais fechadas de tecidos; construção de tecidos com fibras de origem vegetal ou animal ou misturas com fibras sintéticas (com ou sem aditivação de retardantes de chamas) para agregação de funcionalidade; mudanças na modelagem das peças; e estudar alteração na gramatura dos tecidos e da torção dos seus fios constituintes.

Palavras-chave: Inflamabilidade. Uniforme. Aviação civil. Material têxtil. Análise estatística dos fatores. 


\begin{abstract}
SILVA, Marcia Cristina. Analysis of textile flammability of the flight crew uniform. 2018. 213 p. Dissertation (Master of Science) - School of Arts, Sciences and Humanities, University of São Paulo, São Paulo, 2018. Corrected version.
\end{abstract}

The flammability conditions laid down in the aeronautical standards applied to the textiles forming part of the passenger cabin of the aircraft. But these standards are not required for application to crew uniforms. However, since it is part of the function of the crew, notably flight attendants, the fire fighting on board, even if this type of accident is not frequent in relation to all accidents in general in this sector, this fact directed the present study to know the limits of the textile materials of the uniforms of the aeronauts with respect to the flammability. Thus, the objectives were: to determine the flammability (burning rate) of professional fabric samples and samples of aeronaut uniform pieces; characterize the professional fabrics and those that constitute parts of uniforms of aeronauts, through tests of: composition, weights, number of threads per weft and warp, weaving, fabric thickness, yarn diameter, linear density and torsion; calculate the yarn diameter and coverage factor and correlate the values of flammability obtained with the tissue characterization values and calculated parameters. The experiments were carried out in three professional fabrics and in eight pieces of uniforms of aeronauts from different companies donated for this study, in addition to semi-structured interviews and technical visits. The interpretation of the obtained results was carried out with application of tests of normality of data, equality of variances, ANOVA and response surface. The results found in the present study do not fit within the limits recommended by FAR25 for the material to be qualified self-extinguishing. The lowest flammability value was $0.742 \pm 0.140(\mathrm{~cm} / \mathrm{s})$. This result is the mean obtained from the burning rate of the 10 samples tested from the fabric of the P7 piece (male trousers) in the direction of the weft. The composition of the piece is a mixture of $50 \%$ wool and $50 \%$ polyester with a weight of $225.12 \pm 5.02(\mathrm{~g} / \mathrm{m} 2)$, linear yarn density of $36.61 \pm 1.48$ (tex) and a twist of $598.00 \pm 45.34$ (torsions $/ \mathrm{m}$ ). The yarn diameter calculated by the Peirce model was $0.219 \mathrm{~mm}$. The highest flammability value was $3.698 \pm$ $1.806(\mathrm{~cm} / \mathrm{s})$. This result is the mean obtained from the burning rate of the 10 samples tested from the fabric of the piece P5 (male shirt) in the direction of the weft. The composition of the piece is a mixture of $67 \%$ polyester and $33 \%$ cotton with weights of $108.72 \pm 2.39(\mathrm{~g} / \mathrm{m} 2)$, linear yarn density of $15.88 \pm 1.27$ (tex) and twisting of $991.00 \pm 45.75$ (torsions $/ \mathrm{m}$ ). The wire diameter calculated by the Peirce model was $0.148 \mathrm{~mm}$. The analysis of variance with all the factors was not validated by the residue analysis. However, the relationship between the explanatory variables "direction", "material" and "ligament" with the variable "burning rate" grouping by specific physical characteristics, resulted in analyzes validated by their residues. Influence of the "direction" on the "burning rate" for group "material 100\% CO, plain weave", the burning speed is statistically equal in the direction of warp and weft, group " material 100\% PES, twill weave", burning rate is a statistically different one, being smaller in the direction of the weft, group "material 100\% PES, plain weave", the burning speed is statistically different, being smaller in the direction of the warp, group "material 67\% PES / 33\% CO, twill weave" and "material $67 \%$ PES / 33\% CO, plain weave", the burning speed is statistically equal in the direction of warp and warp and group "material 50\% WO / 50\% PES, plain weave", the speed of burn is equal in the direction of warp and warp. Influence of the "material" on the "burning rate": group "twill weave, direction weft" burning rate is statistically different, being smaller to material $100 \% \mathrm{CO}$, group "twill weave, direction warp" burning rate is statiscally different, being smaller to material $100 \% \mathrm{CO}$, group "plain weave, direction weft", burning rate is statiscally equal to material $100 \% \mathrm{CO}, 100 \% \mathrm{PES}, 67 \% / 33 \% \mathrm{CO}$ and $50 \% \mathrm{WO} / 50 \% \mathrm{PES}$, group "plain weave, direction warp" burning rate is statiscally equal to material $67 \% \mathrm{PES} / 33 \% \mathrm{CO}$. 
Thus suggestions for future studies may take into account more closed constructions of tissues; fabric construction with fibers of vegetable or animal origin or mixtures with synthetic fibers (with or without additives of flame retardants) for aggregation of functionality; changes in the modeling of parts; and to study alteration in the weight of the tissues and the torsion of their constituent yarns.

Keywords: Flammability. Uniform. Civil aviation. Textile materials. Statistical analysis of factors. 


\section{LISTA DE ILUSTRAÇÕES}

Figura 1 - Comissária de Voo - Enxoval Completo..................................................................4

Figura 2 - Estrutura da Cadeia produtiva e de distribuição Têxtil e Confecção........................49

Figura 3 - Classificação das fibras têxteis ......................................................................51

Figura 4 - Secção Transversal das fibras. (a) Circular, (b) "dog bone", (c) Trilobal, (d)

Multilobal, (e) Serrilhado, (f) Oco...................................................................................54

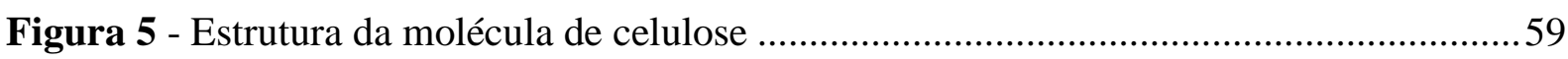

Figura 6 - (a) Capulho de algodão maduro; (b) Algodão colorido, BRS Rubi........................59

Figura 7 - Microscopia da fibra de algodão (a) Secção Transversal (b) vista longitudinal ....61

Figura 8 - Linum usitatissimum. (a) caule e (b) plantação comercial.

Figura 9 - Fibra de lã. (a) Secção longitudinal da fibra. (b) Secção transversal: (A). Bainha exterior ou epicutícula; (B) Camada de escamas; (C) Córtex e (D) Medula.

Figura 10 - Aramida (a) PMPI - poly (m-phenylene isophthalamide), nomes comerciais Nome ${ }^{\circledR}$ (DuPont), Phenylon ${ }^{\circledR}$ (Rússia), Teijinconex ${ }^{\circledR}$ (Teijin Aramid), (b) (p-phenylene terephthalamide), PPPT, nomes comerciais $\operatorname{Kevlar}^{\circledR}$ (DuPont), Twaron ${ }^{\circledR}$ (Teijin Aramid).....71

Figura 11 - (a) Triângulo do Fogo, (b) Tetraedro do Fogo .....................................................75

Figura 12 -Evolução do fogo em uma sala na ausência de controle de fogo. ...........................79

Figura 13 - Cabine Airbus A320 - Mapa de Assentos ..............................................................89

Figura 14 - Esquema para medição de camisa e blusa ...............................................................97

Figura 15 - Esquema para medição de calça ………………………………………………...97

Figura 16 - Ligamento ou Debuxo: (a) Tela ou Tafetá; (b) Sarja; (c) Cetim. .........................99

Figura 17 - Lente conta fios com base graduada de $1 \mathrm{~cm}$ e aumento de 10 vezes, Intex Brasil

Figura 18 - Crimp Tester marca Maillemetre ....................................................................... 102

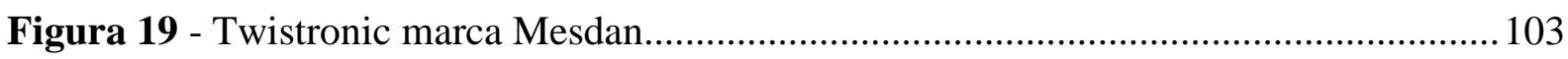

Figura 20 - Encapsulamento dos fios têxteis: (a) Esquema do fio em cápsula de resina; (b)

Esquema de corte transversal. 104 
Figura 21 - Micrótomo semi-automatizado rotacional (Leica, modelo RM 2245, Alemanha)

Figura 22 - Métodos para medição do diâmetro de fios têxteis por microscopia óptica do fio de urdume de T1 (100\% CO). (a) medida linear na vista transversal com aumento de 128 vezes (escala $100 \mu \mathrm{m}$ ); (b) medida de raio na vista transversal com aumento de 128 vezes (escala $100 \mu \mathrm{m})$ e (c) medida linear na vista longitudinal com aumento de 80 vezes (escala 1 $\mathrm{mm})$.

Figura 23 - Modelo de Peirce para tecidos planos. (d) diâmetro do fio, (D) soma dos diâmetros de fios de urdume e trama, (p) espaçamento entre os fios de trama, (h) deslocamento perpendicular máximo da linha central do fio em relação ao plano do tecido, $(\theta)$ ângulo de inclinação do eixo do fio em relação ao plano do tecido, (1) comprimento do eixo do fio entre as intersecções. Os sufixos 1 e 2 representam urdume e trama, respectivamente.

Figura 24 - Cabine de teste de inflamabilidade (“Cabine UMINHO”) conforme Norma NF G07-182:1985. Posição do corpo-de-prova a $45^{\circ}$.

Figura 25 - Montagem do corpo de prova no quadro. As linhas verdes marcam o comprimento queimado.

Figura 26 - Cabine USP para teste de inflamabilidade.

Figura 27 - Aparelho STA 7000

Figura 28 - Peças de Uniforme da Linha Aérea A. (a) Peça P1 - Camisa feminina com pregas, (b) peça P2 - Camisa Feminina Xadrez, (c) Peça P3 - Camisa Masculina de Serviço. Indicação de escala de $10 \mathrm{~cm}$

Figura 29 - Peças de Uniforme da Linha Aérea B. (a) (b) Peças P4 e P5 - Camisas masculinas, (c) Peça P6 - Paletó de 4 botões, (d) Peça P7 - Calça, formando conjunto de terno com a P6, (e) Peça P8 - Paletó de 1 botão. Indicação de escala de $10 \mathrm{~cm}$.

Figura 30 - Resultados da determinação do FTIR da análise dos tecidos em comparação ao padrão da biblioteca do equipamento Thermo Avatar 370 FTIR: (a) padrão 100\% Algodão CO (vermelho) e para o tecido profissional T1 (verde); (b) padrão 100\% Poliéster - PES (vermelho) e para o tecido profissional T3 (lilás).

Figura 31 - Resultados da determinação do FTIR da análise dos tecidos em comparação ao padrão da biblioteca do equipamento Thermo Avatar 370 FTIR: (a) padrão 50\% Algodão - 
CO e 50\% Poliéster PES (vermelho) e para o tecido profissional T2 (azul claro); (b) padrão $50 \%$ Algodão - CO e 50\% Poliéster PES (preto) e para o tecido da peça P1 (azul), peça P2 (verde), peça P3 (vermelho).

Figura 32 - Resultados da determinação do FTIR da análise dos tecidos em comparação ao padrão da biblioteca do equipamento Thermo Avatar 370 FTIR: (a) padrão 100\% Poliéster PES (vermelho) e 100\% Lã WO (verde) para o tecido da peça P6 (laranja), peça P7 (azul); (b) padrão 100\% Poliéster PES (verde escuro) e 100\% Lã WO (verde claro) para o tecido da peça P8 (vermelho).

Figura 33 - Médias da variável resposta "velocidade de queima" com relação a variável explicativa "direção" no grupo de material "algodão $(100 \% \mathrm{CO})$ e ligamento sarja":(a) Gráfico de efeitos; (b)Médias com respectivos de intervalos de confiança (95\%).

Figura 34 - Resultados da análise dos resíduos da ANOVA relacionando a variável resposta "velocidade de queima" com a variável explicativa "direção" para o grupo de dados relativos ao "material algodão (100\%CO), ligamento sarja": (a) Histograma dos resíduos; (b) Papel de probabilidade; (c) Resíduos por valores ajustados; (d) Resíduos por Ordem de coleta 145

Figura 35 - Teste de Bartlett para Análise de Variância dos resíduos relacionando a variável resposta "velocidade de queima" com a variável explicativa "direção" no grupo de dados relativos ao "material algodão $(100 \% \mathrm{CO})$, ligamento sarja":

Figura 36 - Médias da variável resposta "velocidade de queima" com relação a variável explicativa "direção" para grupo de material "poliéster (100\% PES) e ligamento sarja": (a) Gráfico de efeitos; (b) Médias com respectivos de intervalos de confiança (95\%).

Figura 37 - Resultados da análise dos resíduos da ANOVA relacionando a variável resposta "velocidade de queima" com a variável explicativa "direção" no grupo de dados relativos ao "material poliéster (100\%PES) com ligamento sarja": (a) Histograma dos resíduos; (b) Papel de probabilidade; (c) Resíduos por valores ajustados; (d) Resíduos por Ordem de coleta.... 148 Figura 38 - Teste de Bartlett para Análise de Variância dos resíduos relacionando a variável resposta "velocidade de queima" com a variável explicativa "direção" no grupo de dados relativos ao "material poliéster $(100 \% \mathrm{PES})$ com ligamento sarja":

Figura 39 - Teste de múltiplas comparações de Hsu relacionando a variável resposta "velocidade de queima" com a variável explicativa "direção" no grupo de dados relativos ao "material poliéster (100\%PES) com ligamento sarja": 
Figura 40 - Médias da variável resposta "velocidade de queima" com relação a variável explicativa "direção" para o grupo de material "poliéster (100\% PES) e ligamento tela": (a) Gráfico de efeitos; (b) Médias com respectivos de intervalos de confiança (95\%).

Figura 41 - Resultados da análise dos resíduos da ANOVA relacionando a variável resposta "velocidade de queima" com a variável explicativa "direção" no grupo de dados relativos ao "material poliéster (100\%PES) com ligamento tela": (a) Histograma dos resíduos; (b) Papel de probabilidade; (c) Resíduos por valores ajustados; (d) Resíduos por Ordem de coleta.... 151 Figura 42 - Teste de Bartlet para Análise de Variância dos resíduos relacionando a variável resposta "velocidade de queima" com a variável explicativa "direção" no grupo de dados relativos ao "material poliéster $(100 \% \mathrm{PES})$ com ligamento tela":

Figura 43 - Teste de múltiplas comparações de HSU relacionando a variável resposta "velocidade de queima" com a variável explicativa "direção" no grupo de dados relativos ao "material poliéster (100\%PES) com ligamento tela":

Figura 44 - Médias da variável resposta "velocidade de queima” para “67\%poliéster $/ 33 \%$ algodão e ligamento sarja" (a) Gráfico de efeitos; (b) Médias com respectivos de intervalos de confiança $(95 \%)$

Figura 45 - Resultados da análise dos resíduos da ANOVA relacionando a variável resposta "velocidade de queima" com a variável explicativa "direção" no grupo de dados relativos ao "material 67\%poliéster/33\% algodão e ligamento sarja": (a) Histograma dos resíduos; (b) Papel de probabilidade; (c) Resíduos por valores ajustados; (d) Resíduos por Ordem de coleta.

Figura 46 - Teste de Levene para Análise de Variância dos resíduos relacionando a variável resposta "velocidade de queima" com a variável explicativa "direção" no grupo de dados relativos ao "material $67 \%$ poliéster/33\% algodão e ligamento sarja":

Figura 47 - Médias da variável resposta "velocidade de queima" com relação a variável explicativa "direção" para o grupo de "material 67\%poliéster $/ 33 \%$ algodão e ligamento tela" (a) Gráfico de efeitos; (b) Médias com respectivos de intervalos de confiança (95\%).

Figura 48 - Resultados da análise dos resíduos da ANOVA relacionando a variável resposta "velocidade de queima" com a variável explicativa "direção" no grupo de dados relativos ao "material 67\%poliéster/33\% algodão e ligamento tela" (a) Histograma dos resíduos; (b) Papel de probabilidade; (c) Resíduos por valores ajustados; (d) Resíduos por Ordem de coleta.... 158 
Figura 49 - Teste de Bartlett para Análise de Variância dos resíduos relacionando a variável resposta "velocidade de queima" com a variável explicativa "direção" no grupo de dados relativos ao "material $67 \%$ poliéster $/ 33 \%$ algodão e ligamento tela":

Figura 50 - Médias da variável resposta "velocidade de queima" com relação a variável explicativa “direção" para o grupo de "material 50\% lã(WO)/ 50\% poliéster(PES) e ligamento tela": (a) Gráfico de efeitos; (b) Médias com respectivos de intervalos de confiança $(95 \%)$

Figura 51 - Resultados da análise dos resíduos da ANOVA relacionando a variável resposta "velocidade de queima" com a variável explicativa "direção" no grupo de dados relativos ao "material 50\% lã(WO)/ 50\% poliéster(PES) e ligamento tela": (a) Histograma dos resíduos; (b) Papel de probabilidade; (c) Resíduos por valores ajustados; (d) Resíduos por Ordem de coleta.

Figura 52 - Teste de Levene para Análise de Variância dos resíduos relacionando a variável resposta "velocidade de queima" com a variável explicativa "direção" no grupo de dados relativos ao "material 50\% lã(WO)/ 50\% poliéster(PES) e ligamento tela":

Figura 53 - Médias da variável resposta "velocidade de queima" com relação a variável explicativa "material" para o grupo para "ligamento sarja, direção trama": (a) Gráfico de efeitos; (b) Médias com respectivos de intervalos de confiança (95\%).

Figura 54 - Resultados da análise dos resíduos da ANOVA relacionando a variável resposta "velocidade de queima" com a variável explicativa "material" no grupo de dados relativos ao "ligamento sarja, direção trama":(a) Histograma dos resíduos; (b) Papel de probabilidade; (c) Resíduos por valores ajustados; (d) Resíduos por Ordem de coleta. 164

Figura 55 - Teste de Levene para Análise de Variância dos resíduos relacionando a variável resposta "velocidade de queima" com a variável explicativa "material" no grupo de dados relativos ao "ligamento sarja, direção trama".

Figura 56 - Teste de múltiplas comparações de HSU relacionando a variável resposta "velocidade de queima" com a variável explicativa "material" no grupo de dados relativos ao "ligamento sarja, direção trama".

Figura 57 - Médias da variável resposta "velocidade de queima" para "ligamento sarja, direção urdume": (a) Gráfico de efeitos; (b) Médias com respectivos de intervalos de confiança (95\%) 
Figura 58 - Resultados da análise dos resíduos da ANOVA relacionando a variável resposta "velocidade de queima" com a variável explicativa "material" no grupo de dados relativos ao "ligamento sarja, direção urdume":(a) Histograma dos resíduos; (b) Papel de probabilidade; (c) Resíduos por valores ajustados; (d) Resíduos por Ordem de coleta 168

Figura 59 - Teste de múltiplas comparações de HSU variável resposta "velocidade de queima" com a variável explicativa "material" no grupo de dados relativos ao "ligamento sarja, direção urdume

Figura 60 - Médias da variável resposta "velocidade de queima" por "material" para grupo "ligamento tela, direção trama": (a) Gráfico de efeitos; (b) Médias com respectivos de intervalos de confiança (95\%).

Figura 61 - Resultados da análise dos resíduos da ANOVA relacionando a variável resposta "velocidade de queima" com a variável explicativa "material" no grupo de dados relativos ao "ligamento tela, direção trama":(a) Histograma dos resíduos; (b) Papel de probabilidade; (c) Resíduos por valores ajustados; (d) Resíduos por Ordem de coleta. 171

Figura 62 - Médias da variável resposta "velocidade de queima" para "ligamento tela, direção urdume": (a) Gráfico de efeitos; (b) Médias com respectivos de intervalos de confiança $(95 \%)$

Figura 63 - Resultados da análise dos resíduos da ANOVA relacionando a variável resposta "velocidade de queima" com a variável explicativa "material" no grupo de dados relativos ao "ligamento tela, direção urdume":(a) Histograma dos resíduos; (b) Papel de probabilidade; (c) Resíduos por valores ajustados; (d) Resíduos por Ordem de coleta.

Figura 64 - Teste de Bartlett para Análise de Variância dos resíduos relacionando a variável resposta "velocidade de queima" com a variável explicativa "material" no grupo de dados relativos ao "ligamento tela, direção urdume"

Figura 65 - Teste de múltiplas comparações de HSU relacionando a variável resposta "velocidade de queima" com a variável explicativa "material" no grupo de dados relativos ao "ligamento tela, direção urdume"

Figura 66 - Curvas DSC para (a) T1(100\%CO) e (b) T2 (67\%PES/33\%CO).Velocidade de aquecimento $10^{\circ} \mathrm{C} / \mathrm{min}$.

Figura 67 - Curvas STA para (a) T1(100\%CO) e (b) T2 (67\%PES/33\%CO).Temperatura de $30^{\circ} \mathrm{C}$ a $600^{\circ} \mathrm{C}$ e velocidade de aquecimento $10^{\circ} \mathrm{C} / \mathrm{min}$. 


\section{LISTA DE GRÁFICOS}

Gráfico 1 - Produção Mundial de Algodão em 2016............................................................60

Gráfico 2 - Produção Mundial de Linho, 2016.

Gráfico 3 - Valores de velocidade de queima $(\mathrm{cm} / \mathrm{s})$ do Tecido T1 na Cabine UMINHO direção trama (azul) e direção urdume (vermelho) e Cabine USP.na direção da trama (verde) e na direção do urdume (amarelo). Os valores estão expressos em velocidade de queima para cada observação.

Gráfico 4 - Valores de velocidade de queima $(\mathrm{cm} / \mathrm{s})$ do Tecido T2 na Cabine UMINHO direção trama (azul) e direção urdume (vermelho) e Cabine USP.na direção da trama (verde) e na direção do urdume (amarelo). Os valores estão expressos em velocidade de queima para cada observação. 


\section{LISTA DE QUADROS}

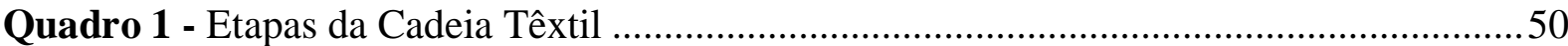

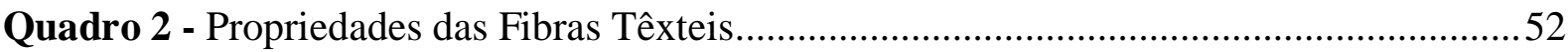




\section{LISTA DE TABELAS}

Tabela 4.1 - Movimentação do Aeroporto Internacional de Guarulhos em 2017 ...................37

Tabela 4.2 - Movimentação do Aeroporto de Congonhas em 2017 ........................................37

Tabela 4.3 - Movimentação do Aeroporto Internacional de Viracopos em 2017 ...................38

Tabela 4.4 - Movimentação do Aeroporto do Campo de Marte em 2017...............................38

Tabela 4.5 - Movimentação do Aeroporto Internacional de São José dos Campos em 2017 .39

Tabela 4.6 - Transição Térmica das fibras têxteis mais comuns ...........................................58

Tabela 4.7 - Composição Química do algodão.....................................................................62

Tabela 4.8 - Componente Químicos de diferentes materiais de fibra de caule ......................62

Tabela 4.9 - Comparação das propriedades mecânicas e térmicas entre fibras de para-

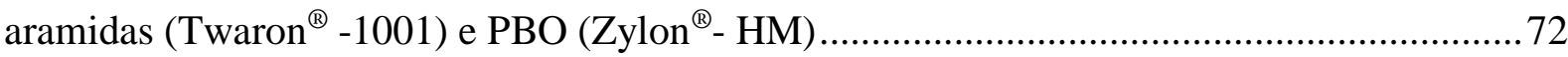

Tabela 4.10 - Classificação de LOI frente a inflamabilidade ............................................... 82

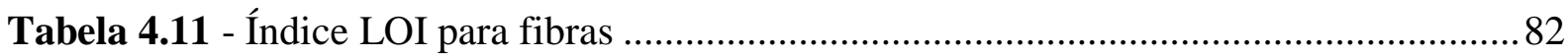

Tabela 4.12 - Resumo dos critérios de teste para classificação das amostras em termos de tempo de queima em segundos (s)

Tabela 5.1 - Faixas de gramatura $\left(\mathrm{em} \mathrm{g} / \mathrm{m}^{2}\right)$ definindo têxteis como de gramatura leve, média,

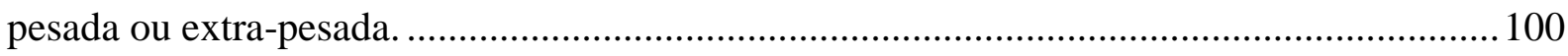

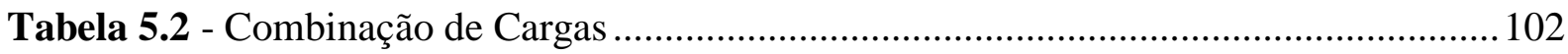

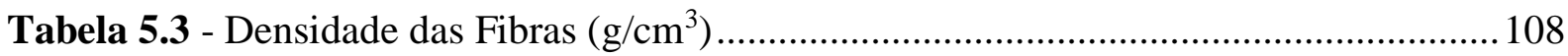

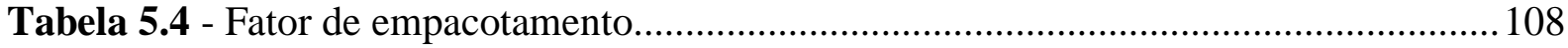

Tabela 5.5 - Fator de correlação de Pearson como medida de associação linear entre as variáveis.

Tabela 6.1 - Dimensões das Peças de Uniforme - Camisas e Paletós................................... 126

Tabela 6.2 - Dimensões das Peças de Uniforme - Calça .................................................... 126 
Tabela 6.3 - Características dos Tecidos dos Uniformes de Aeronautas e Tecidos adquiridos no mercado, expressos em tipo fibra (composição do material, sendo CO - algodão, PES poliéster e WO - lã), ligamento, densidade de fios (TR, número de fios por cm na trama e UR, número de fios por $\mathrm{cm}$ no urdume), espessura e gramatura. Estes dois últimos, expressos em termos de média e desvio padrão de 10 medições e entre parênteses é indicado o coeficiente de variação.

Tabela 6.4 - Características de densidade linear e torções dos fios de trama e urdume retirados dos tecidos adquiridos no mercado e dos Uniformes de Aeronautas. Os valores estão expressos em termos de média e desvio padrão de 10 medições e entre parênteses é indicado o coeficiente de variação.

Tabela 6.5 - Valores de diâmetro em mm, determinados para os fios de trama e urdume, nos três modos de medição (largura, por eixos perpendiculares e por circunferência) dos tecidos adquiridos no mercado e dos uniformes de aeronautas. Os valores estão expressos em termos de média e desvio padrão de 10 medições e entre parênteses é indicado o coeficiente de variação

Tabela 6.6 - Valores de diâmetro $(\mathrm{mm})$, calculados para os fios de trama e urdume considerando o fio com seção circular (Equação 6) e calculados pelo modelo de Peirce (Equação 7)

Tabela 6.7 - Valores de fator de cobertura determinados para os tecidos profissionais adquiridos no mercado e dos uniformes de aeronautas.

Tabela 6.8 - Valores de velocidade de queima $(\mathrm{cm} / \mathrm{s})$, determinados para dois tecidos adquiridos no mercado (T1 e T2) na Cabine UMINHO e Cabine USP. Os valores estão expressos em termos de média e desvio padrão de 10 medições e entre parênteses é indicado o coeficiente de variação.

Tabela 6.9 - Valores de velocidade de queima $\mathrm{em} \mathrm{cm} / \mathrm{s}$, determinados para dois tecidos adquiridos no mercado (T1 e T2) e peças de uniformes (P1 a P8) na Cabine USP, nos sentidos de trama e urdume. Os valores estão expressos em termos de média e desvio padrão de 10 medições e entre parênteses é indicado o coeficiente de variação.

Tabela 6. 10 - ANOVA - variável resposta "velocidade de queima" com relação as variáveis explicativas "fios de trama", "fios de urdume", "fator de cobertura”, "torção", "gramatura”, "espessura", "diâmetro do fio" e "densidade" 
Tabela 6. 11 - ANOVA - variável resposta "velocidade de queima" com relação a variável explicativa "direção" entre grupos de material "algodão $(100 \% \mathrm{CO})$ e ligamento sarja" ..... 143

Tabela 6. 12 - ANOVA - variável resposta "velocidade de queima" com relação a variável explicativa "direção" entre grupos de material "poliéster (100\% PES) e ligamento sarja".. 146

Tabela 6. 13 - ANOVA - variável resposta "velocidade de queima" com relação a variável explicativa "direção" para o grupo "material poliéster (100\% PES) e ligamento tela"

Tabela 6. 14 - ANOVA - variável resposta "velocidade de queima" com relação a variável explicativa "direção" para o grupo "material 67\%poliéster/33\% algodão e ligamento sarja"

Tabela 6. 15 - ANOVA - variável resposta "velocidade de queima" com relação a variável explicativa "direção" entre grupos de material " $67 \%$ poliéster $/ 33 \%$ algodão e ligamento tela"

Tabela 6. 16 - ANOVA - variável resposta "velocidade de queima" com relação a variável explicativa “direção" entre grupos de "material 50\% lã(WO)/ 50\% poliéster(PES) e ligamento tela",

Tabela 6. 17 - ANOVA - variável resposta "velocidade de queima" com relação a variável explicativa "material" para o grupo "ligamento sarja, direção trama

Tabela 6. 18 - ANOVA - variável resposta "velocidade de queima" com relação a variável explicativa "material" entre grupos de "ligamento sarja, direção urdume".

Tabela 6. 19 - Teste Kruskal-Wallis para a variável resposta "velocidade de queima" com a variável explicativa "material" no grupo de dados relativos ao "ligamento sarja, direção urdume".

Tabela 6. 20 - ANOVA - variável resposta "velocidade de queima" com relação a variável explicativa "material" entre grupos de "ligamento tela, direção trama".

Tabela 6. 21 - Teste Kruskal-Wallis para a variável resposta "velocidade de queima" com a variável explicativa "material" no grupo de dados relativos ao "ligamento tela, direção trama".

Tabela 6. 22 - ANOVA - variável resposta "velocidade de queima" com relação a variável explicativa "material" entre grupos de "ligamento tela, direção urdume". 
Tabela 6. 23 - Resumo da análise estatística para variável resposta "velocidade de queima" com relação as três variáveis explicativas ("direção", "material”, "ligamento").. 


\section{LISTA DE EQUAÇÕES}

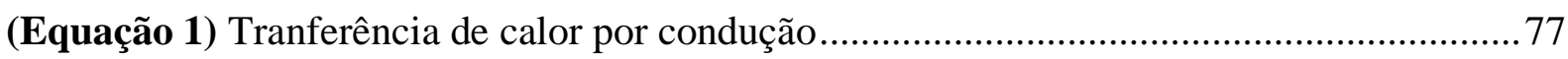

(Equação 2) Tranferência de calor por convecção ........................................................... 78

(Equação 3) Transferência de calor por radiação ............................................................. 78

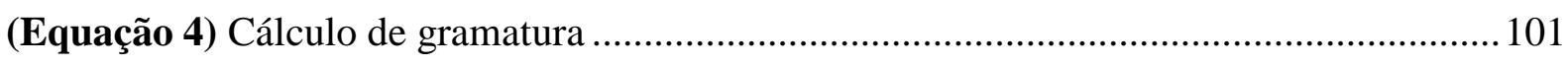

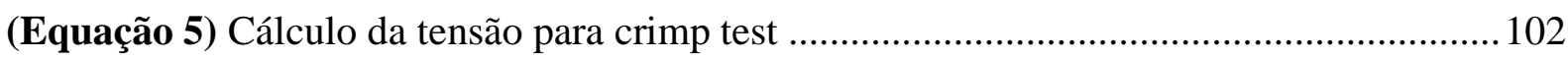

(Equação 6) Modelo de Peirce - secção circular................................................................. 108

(Equação 7) Modelo de Peirce - secção alongada ........................................................... 108

(Equação 8) Cálculo densidade de fibras misturadas ........................................................ 109

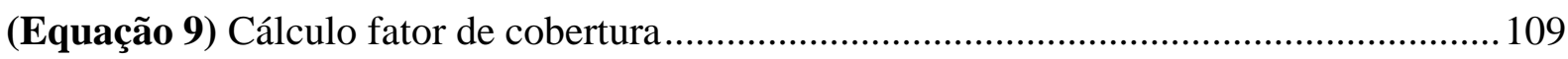

(Equação 10) Cálculo da velocidade de queima............................................................. 109

(Equação 11) Variação do erro de medição ...................................................................... 113

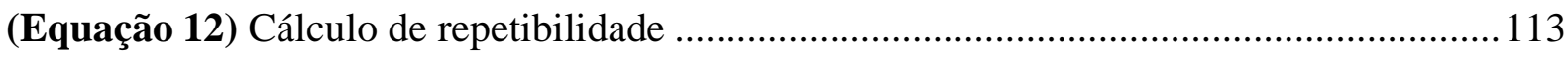

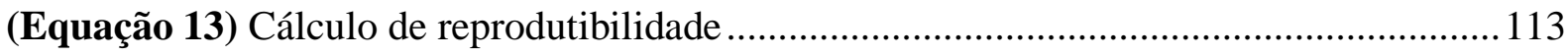

(Equação 14) Capacidade do sistema de medição: R\&R ................................................. 114

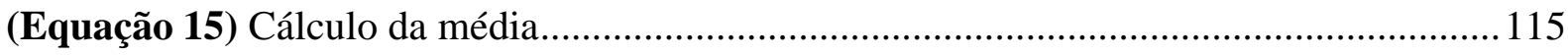

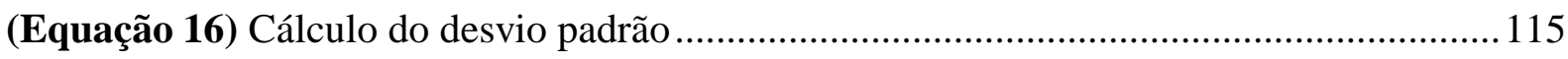

(Equação 17) Cálculo do coeficiente de variação .......................................................... 115

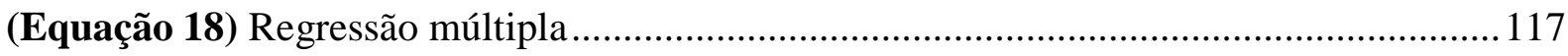




\section{SUMÁRIO}

4.1.1 Importância do setor no Brasil .....................................................................36

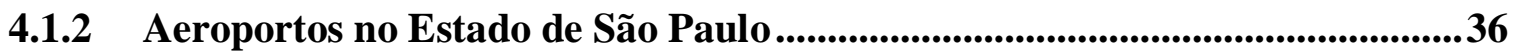

4.1.3 Aeronaves: Integridade do Produto e do Processo...............................................39

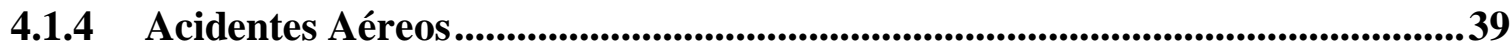

ATRIBUIÇÕES DOS AERONAUTAS …..............................................

4.2.1 Profissão de comissário de voo e suas atribuições .................................................41

4.2.2 Início da profissão de comissários de voo no Brasil .........................................43

4.2.3 Treinamento e qualificação................................................................................................43

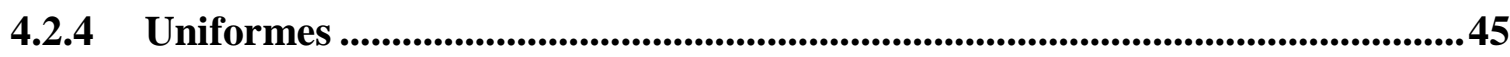

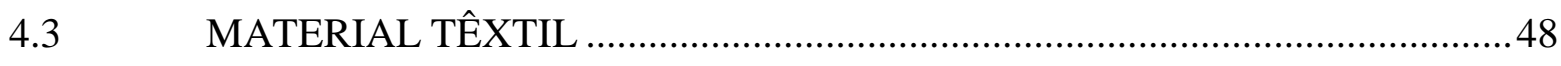

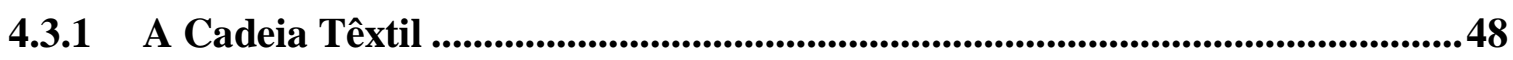

4.3.2 Fibras Têxteis...........................................................................................50

4.3.2.1 Propriedades das Fibras Têxteis ..................................................................52

4.3.2.2 Propriedades Dimensionais das Fibras ..............................................52

4.3.2.3 Propriedades Mecânicas das Fibras ......................................................55

4.3.2.4 Ensaio Tênsil de Tração ................................................................................55

4.3.2.5 Propriedades de absorção das Fibras ..........................................................56 
4.3.2.6 Propriedades Químicas das Fibras ........................................................56

4.3.2.7 Propriedades Térmicas das Fibras...............................................................57

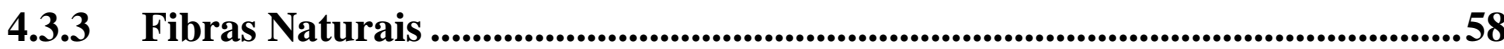

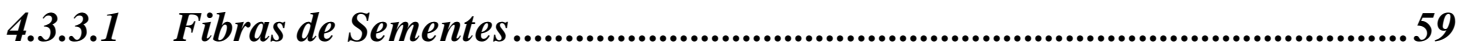

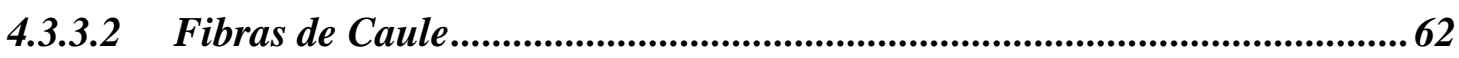

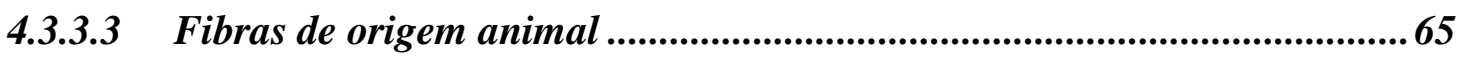

4.3.4 Fibras Manufaturadas .....................................................................................69

4.3.4.1 Conceitos básicos sobre polímeros .......................................................69

4.3.4.2 Decomposição térmica de um polímero........................................................70

4.3.4.3 Fibras de alto desempenho ............................................................................71

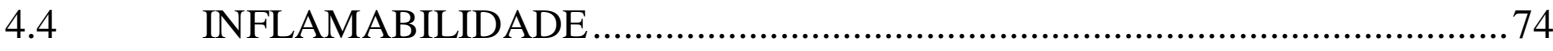

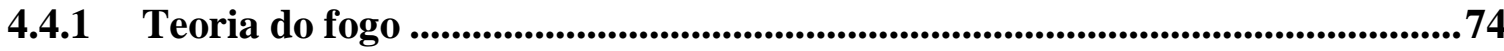

4.4.2 Inflamabilidade dos materiais e seus elementos. ….............................................75

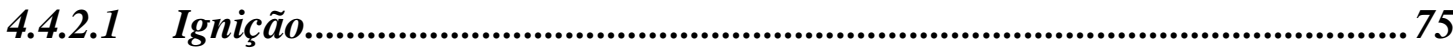

4.4.2.2 Propagação superficial da chama...........................................................75

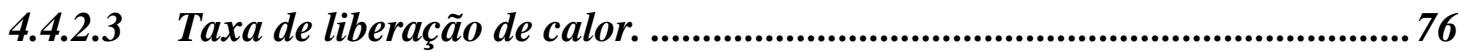

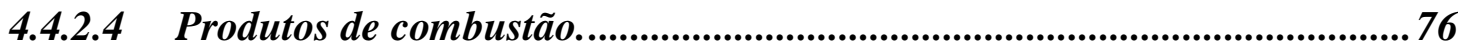

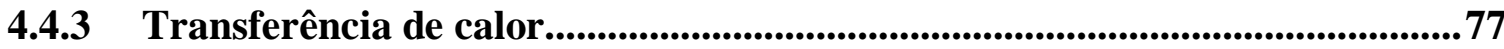

4.4.3.1 Transferência de calor por condução. ....................................................77

4.4.3.2 Transferência de calor por convecção...................................................78

4.4.3.3 Transferência de calor por radiação.......................................................78

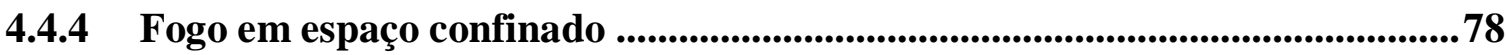

4.4.5 Fatores de influência da inflamabilidade de têxteis ..........................................80

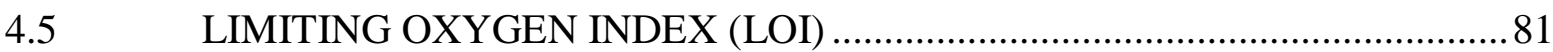

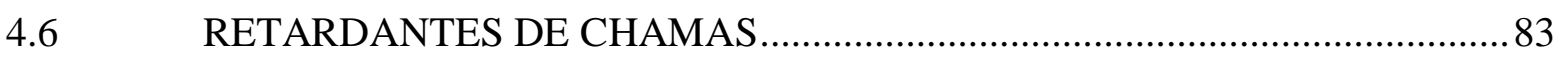

4.6.1 Modo de ação dos retardantes de chamas ....................................................83 


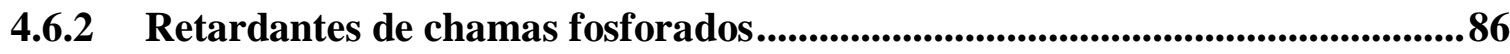

4.6.3 Retardantes de chamas com compostos halogenados .....................................87

4.6.4 Hidróxidos Inorgânicos ................................................................................................87

4.7 NORMAS DE INFLAMABILIDADE DOS MATERIAIS TÊXTEIS NA

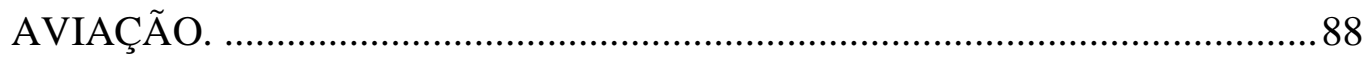

4.8 TESTES DE INFLAMABILIDADE EM TÊXTEIS ......................................90

5

MATERIAIS E MÉTODOS ...........................................................................93

5.1 LEVANTAMENTO BIBLIOGRÁFICO E DOCUMENTAL E

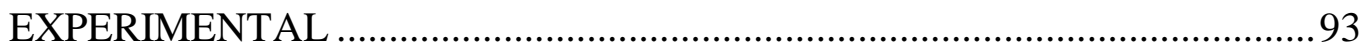

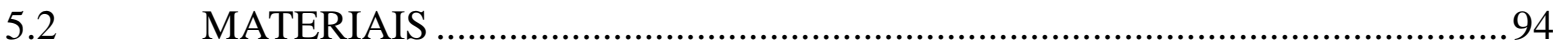

5.2.1 Uniforme de Aeronautas. ..................................................................................94

5.2.2 Tecidos comerciais para uniformes..............................................................94

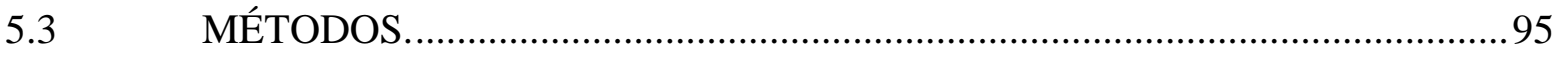

5.3.1 Contato com as Linhas Aéreas. ......................................................................................95

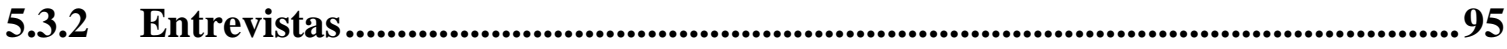

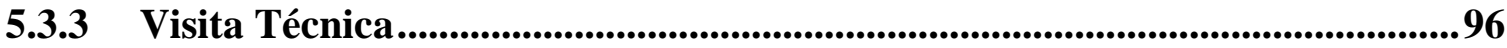

5.3.4 Características dos uniformes de aeronautas ............................................96

5.3.4.1 Registro Fotográfico dos uniformes dos aeronautas. ...............................96

5.3.4.2 Dimensionamento dos uniformes dos aeronautas.......................................97

5.3.5 Caracterização do material têxtil aplicado aos uniformes dos aeronautas e tecidos profissionais.....................................................................................98

5.3.5.1 Composição da Fibra Têxtil: Etiqueta e por FTIR (Fourier Transform Infrared Spectroscopy) ................................................................................98

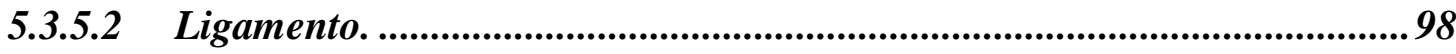

5.3.5.3 Determinação número de fios por trama e urdume ...................................99

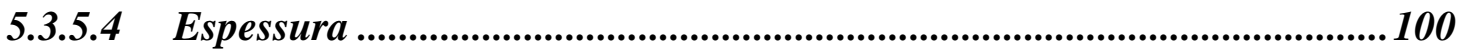

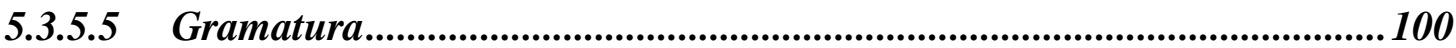


5.3.5.6 Determinação da densidade linear......................................................101

5.3.5.7 Determinação da contração ........................................................................ 101

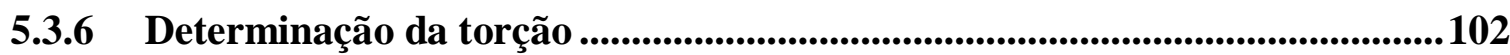

5.3.6.1 Medição do Diâmetro dos fios por microscopia ótica. .............................103

5.3.6.2 Cálculo do diâmetro dos fios com aplicação de modelo geométrico. ...... 107

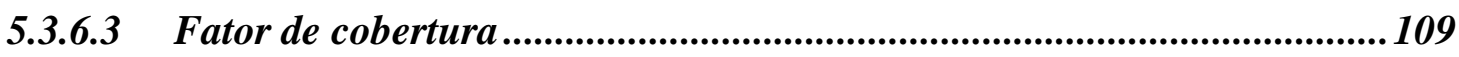

5.3.7 Ensaio de Inflamabilidade na Universidade do Minho - Portugal ................ 109

5.3.8 Ensaio de Inflamabilidade na Universidade de São Paulo- USP...................111

5.3.9 Análise do sistema de medição da Cabine USP. .........................................112

5.3.10 Determinação da velocidade de queima dos tecidos dos uniformes dos aeronautas ..................................................................................................................................... 114

5.3.11 Digital Scanning Calorimetry (DSC): .......................................................114

5.3.12 Simultaneous Thermogravimetric analysis (STA) ...........................................115

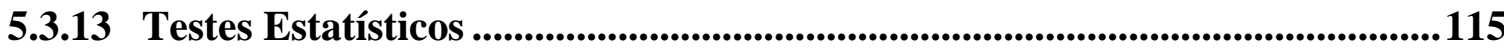

5.3.13.1 Cálculo de média, desvio-padrão e coeficiente de variação.....................115

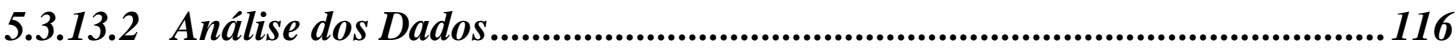

5.3.13.3 Análise de variância (ANOVA) e Regressão Múltipla ............................116

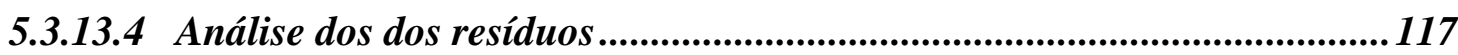

5.3.13.5 Método de comparação múltipla de Hsu ..............................................118

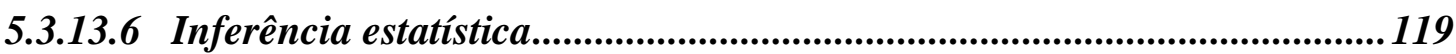

5.3.13.7 Teste de Hipóteses...........................................................................119

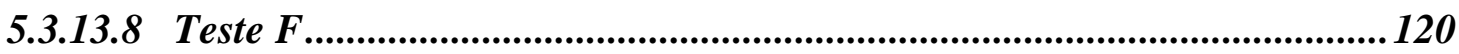

5.3.13.9 Teste não paramétrico de Kruskal- Wallis...................................................120

5.3.13.10 Coeficiente de Correlação de Pearson .....................................................120

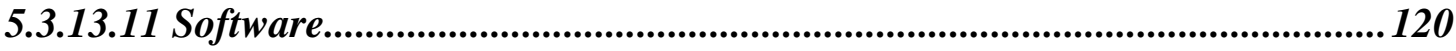


6.1 AUSÊNCIA DE RESPOSTA DAS LINHAS AÉREAS

6.2 ENTREVISTAS.

6.3 VISITA TÉCNICA AO CITEVE - FAMALICÃO, PORTUGAL....................122

6.4 CARACTERIZAÇÃO DOS UNIFORMES DOS AERONAUTAS

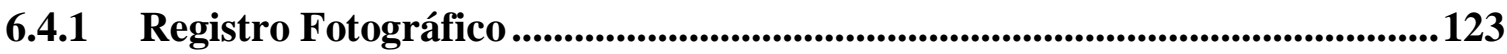

6.4.2 Dimensionamento das Peças de Uniforme .......................................................125

6.5 CARACTERIZAÇÃO DOS MATERIAIS TÊXTEIS DOS UNIFORMES DOS AERONAUTAS E TECIDOS PROFISSIONAIS

6.5.1.1 Confirmação da composição das fibras dos tecidos por FTIR (Fourier Transform Infrared Spetroscopy) ........................................................127

6.5.1.2 Ligamento, fios de trama e urdume, espessura e gramatura................... 129

6.5.1.3 Densidade Linear e Torções do Fio ......................................................... 130

6.5.2 Diâmetro do fio ..................................................................................................................... 132

6.5.3 Fator de Cobertura ......................................................................................... 134

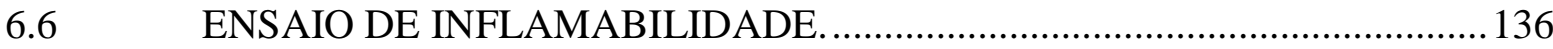

6.6.1 Validação do Sistema de Medição - Cabine USP ...........................................136

6.6.2 Comparação velocidade de queima - Cabine UMINHO e Cabine USP .....136

6.6.3 Velocidade de Queima dos Tecidos dos Uniformes dos Aeronautas na cabine USP.

6.7 ANÁLISE DE ESTATÍSTICA

6.7.1 Análise das variáveis 141

6.7.2 Influência da variável "direção" (trama e urdume) na variável resposta "velocidade de queima".

6.7.2.1 ANOVA - variável resposta "velocidade de queima" com relação a variável explicativa "direção" para o grupo "material algodão (100\%CO) e ligamento sarja”. 
6.7.2.2 ANOVA - variável resposta "velocidade de queima" com relação a variável explicativa "direção" no grupo " material poliéster (100\% PES) e ligamento sarja”.

6.7.2.3 ANOVA - variável resposta "velocidade de queima" com relação a variável explicativa “direção” para grupo ”material poliéster (100\% PES) e ligamento tela”.

6.7.2.4 ANOVA - variável resposta "velocidade de queima” com relação a variável explicativa "direção" para grupo "material 67\%poliéster/33\% algodão e ligamento sarja”.

6.7.2.5 ANOVA - variável resposta "velocidade de queima" com relação a variável explicativa “direção" entre grupos de "material 67\%poliéster/33\% algodão e ligamento tela”.

6.7.2.6 ANOVA - variável resposta "velocidade de queima" com relação a variável explicativa “direção” entre grupos de “material 50\% lã(WO)/ $50 \%$ poliéster(PES) e ligamento tela".

6.7.3 Influência do material dos tecidos na velocidade de queima 162

6.7.3.1 ANOVA - variável resposta "velocidade de queima" com relação a variável explicativa "material” para o grupo "ligamento sarja, direção trama”.

6.7.3.2 ANOVA - variável resposta "velocidade de queima” com relação a variável explicativa "material” entre grupos de "ligamento sarja, direção urdume". 166

6.7.3.3 ANOVA - variável resposta "velocidade de queima" com relação a variável explicativa "material" entre grupos de "ligamento tela, direção trama”.

6.7.3.4 ANOVA - variável resposta "velocidade de queima" com relação a variável explicativa "material” entre grupos de "ligamento tela, direção urdume.

6.7.4 Síntese da Análise Estatística.....................................................................

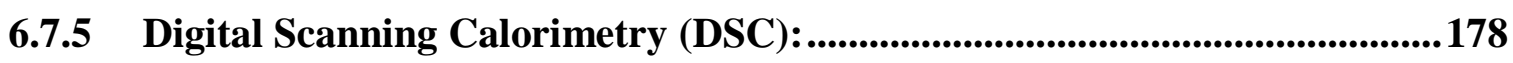


6.7.6 STA (Simultaneous Thermogravimetric analysis)

APÊNDICE A - FICHA DE IDENTIFICAÇÃO DAS PEÇAS DE UNIFORMES DE AERONAUTAS

APÊNDICE B - CARACTERÍSTICAS DO MATERIAL TÊXTIL DOS UNIFORMES DOS AERONAUTAS (P1 A P8) E TECIDOS PROFISSIONAIS (T1 A T3) 


\section{INTRODUÇÃ̃O}

A atividade aeronáutica passa por mudanças que vão desde o aperfeiçoamento dos aviões em suas características de capacidade e tecnologia como também no desenvolvimento dos projetos, processos de fabricação, certificação e manutenção. Tais mudanças contribuíram e continuam contribuindo para a redução significativa dos índices de acidentes aéreos (SANTOS; ALMEIDA; FARIAS, 2018).

Em adição, a inflamabilidade dos materiais têxteis utilizados na cabine de passageiros das aeronaves comerciais é uma parcela importante no planejamento das rotinas de segurança, uma vez que iniciada uma emergência com fogo ou fumaça a bordo, o tempo torna-se crítico e toda a tripulação deve estar envolvida na solução do evento (McKENZIE, 2009).

Nos Estados Unidos, o órgão responsável pela emissão e manutenção das normas para o setor Aeronáutico e Espacial é o Federal Aviation Administration-Department of Transportation. A normativa de interesse para este trabalho é a Federal Aviation Regulation (FAR) part25-Airwothiness Standards transport category airplane, subpart D - Design and Construction $\S 25853$ - Fire Protection - Compartment Interior, a qual aborda as propriedades de reação e resistência ao fogo necessário a um material têxtil que pode fazer parte do compartimento de passageiros de uma aeronave (U.S. DEPARTMENT OF TRANSPORTATION; FEDERAL AVIATION ADMINISTRATION, 2016).

No Brasil a atividade regulatória para aeronaves é feita pela ANAC - Agência Nacional de Aviação Civil, que adota integralmente na língua inglesa o mesmo regulamento Federal Aviation Regulation Part. 25, com o título de RBAC-Regulamento Brasileiro da Aviação Civil n॰ 25 - Requisitos de Aeronavegabilidade: Aviões categoria transporte (ANAC, 2014).

As condições de inflamabilidade estabelecidas nas normas citadas são aplicadas aos têxteis integrantes da cabine de passageiros do avião, não sendo requerida a sua aplicação aos uniformes dos aeronautas.

As roupas profissionais geralmente são feitas de poliéster e suas misturas com algodão por se tratar de um material relativamente barato para a indústria de vestuário, proporcionando o conforto e a respirabilidade do algodão, com a força e durabilidade do poliéster (LEISTNER et al., 2015). Entretanto estas fibras e misturas apresentam baixa estabilidade térmica e alta inflamabilidade (ATTIA; MORSY, 2016). Ao receberem o seu 
conjunto de peças de uniforme, a imagem do comissário passa a ser a marca da empresa (UNITED, 2013).

Tendo em vista uma análise simples de falha potencial, considerando fatores como gravidade, frequência da ocorrência e facilidade em detectar a falha, uma hipótese plausível poderia estar relacionada à raridade dos acidentes que envolvem a questão da inflamabilidade de seus uniformes, ou seja, um risco muito baixo.

O presente estudo consiste em analisar o comportamento de têxteis que compõem as peças de uniforme da tripulação de voo, observando variáveis tais como: velocidade de queima, gramatura, densidade linear, diâmetro do fio, espessura dos tecidos, fator de cobertura, composição de fibras dos tecidos, direção dos fios de trama e urdume em peças de uniformes das Linhas Aéreas brasileiras.

A revisão bibliográfica desenvolvida foi baseada em oito tópicos, com conceitos fundamentais à compreensão do estudo na qual são abordados os seguintes temas: (i) aviação civil; (ii) atribuições dos aeronautas; (iii) material têxtil; (iv) inflamabilidade; (v) Limiting Oxygen Index (LOI); (vi) retardantes de chamas; (vii) normas de inflamabilidade dos materiais têxteis na aviação; e (viii) testes de inflamabilidade em têxteis.

Após apresentar a revisão bibliográfica e a metodologia utilizada, no item "Resultados e Discussão", são apresentados e discutidos os resultados relacionados a: (i) ausência de resposta das linhas aéreas; (ii) entrevistas realizadas com o Sr. Lucas Corvacho da Empresa Retalhar e com o Prof. Dr. Donizeti de Andrade do ITA; (iii) visita técnica ao CITEVE - Famalicão, Portugal; (iv) caracterização dos uniformes dos aeronautas através de registro fotográfico e dimensionamento das peças de uniforme; (v) caracterização dos materiais têxteis dos uniformes dos aeronautas e tecidos profissionais através de: confirmação da composição das fibras dos tecidos por FTIR (Fourier Transform Infrared Spetroscopy), determinação de Ligamento, fios de trama e urdume, espessura e gramatura, densidade linear e torções do fio, cálculo do diâmetro do fio e do Fator de Cobertura; (vi) realização dos ensaios de inflamabilidade na Cabine UMINHO e Cabine USP; (vii) correlação das variáveis através de determinação de modelo para as variáveis independentes na velocidade de queima do material dos uniformes dos aeronautas, análise dos efeitos dos principais fatores na velocidade de queima do material dos uniformes dos aeronauta; (viii) determinação das superfícies de resposta de: gramatura e torção, gramatura e fator de cobertura, e fator de cobertura e torção.

Ao final são apresentadas as principais conclusões e, em base destas sugestões para ensaios futuros. 


\section{JUSTIFICATIVA}

A Lei 7.183/1984 (BRASIL, 1984) que regula o exercício da profissão de aeronauta, na sua seção IV - artigo 46 estabelece que: “o aeronauta receberá gratuitamente da empresa, quando não forem de uso comum, as peças de uniforme e os equipamentos exigidos para o exercício de sua atividade profissional, estabelecidos por autoridade competente".

Também existe a preocupação da apresentação pessoal do funcionário associado ao nome da empresa. Em entrevista publicada pela Revista Atual, Hugo Aspromonte, responsável pelo treinamento dos comissários de voo da empresa TAM na época declarou que: "Os funcionários são o cartão de visitas da empresa. Eles representam a TAM aos olhos do cliente. Portanto, tem de refletir o padrão da empresa”" (ESTILO TAM, 2011).

No Estado de São Paulo operam mais de oitenta aeroportos, que alternam as suas atividades entre transporte de passageiros e carga, da aviação comercial e executiva respondendo por aproximadamente $30 \%$ da movimentação mensal de pousos e decolagens das aeronaves no Brasil (AGÊNCIA NACIONAL DE AVIAÇÃO - ANAC, 2016a).

Tanto a Lei, quanto o treinamento interno da organização não abordam a necessidade do tratamento retardante de chamas em seus uniformes. No entanto, uma vez que faz parte da função da tripulação, notadamente os comissários de voo, o combate de fogo a bordo, mesmo que esse tipo de acidente não seja frequente em relação à totalidade dos acidentes em geral desse setor, esse fato direciona o presente estudo para conhecer os limites dos materiais têxteis dos uniformes dos aeronautas com relação à inflamabilidade, para que atenda a legislação, a estética e a funcionalidade necessária para o combate de incêndios de forma segura. 


\section{OBJETIVOS}

\subsection{GERAL}

Análise da inflamabilidade (velocidade de queima) dos materiais têxteis utilizados na confecção de uniformes de aeronautas (tripulação de voo) de linhas aéreas brasileiras.

\subsection{ESPECÍFICOS}

Como objetivos específicos desta pesquisa:

- Determinar a inflamabilidade (velocidade de queima) de amostra de tecidos profissionais e de amostras de peças de uniformes de aeronautas.

- Caracterizar os tecidos profissionais e os que constituem peças de uniformes de aeronautas, através de testes de: composição, gramatura, número de fio por trama e urdume, ligamento, espessura do tecido, diâmetro de fios, densidade linear e torção.

- Calcular o diâmetro do fio e fator de cobertura.

- Correlacionar os valores obtido de inflamabilidade com os valores da caracterização dos tecidos e parâmetros calculados. 


\section{REVISÃO DA LITERATURA}

\subsection{AVIAÇÃO CIVIL}

A movimentação mundial de passageiros aéreos segundo o relatório do Airport Council International (ACI), o qual divulga anualmente o tráfego aéreo de 2446 aeroportos em 175 países, o total de passageiros que circularam pelo mundo em 2016 foi de 7,7 bilhões, registrando um aumento de 6,5\% sobre os números de 2015.

O ACI divide as operações aéreas em seis grandes regiões, sendo Ásia - Pacífico, Europa, América do Norte, Oriente Médio, África e a região América Latina - Caribe, na qual o Brasil está inserido. A movimentação nesta área foi de 588 milhões de passageiros no ano de 2016 (AIRPORTS COUNCIL INTERNATIONAL, 2017).

\subsubsection{Importância do setor no Brasil}

Nos aeroportos brasileiros, foi registrada em 2016 uma movimentação de 104.793.000 de passageiros, o que representa 1,4\% da movimentação mundial (PERINI et al., 2017).

No Estado de São Paulo, a operação dos cinco principais aeroportos alterna as suas atividades entre transporte de passageiros e carga, da aviação comercial e executiva e respondem por aproximadamente $42 \%$ da movimentação mensal de pousos e decolagens das aeronaves no Brasil. Nestes aeroportos passaram em 2017 cerca de 69.000.000 de passageiros (GRU AIRPORT, 2018; INFRAERO, 2017; PERINI et al., 2017; VIRACOPOS AEROPORTOS BRASIL, 2017).

\subsubsection{Aeroportos no Estado de São Paulo}

O Estado de São Paulo possui aproximadamente 80 aeroportos, porém, os principais para atendimento de passageiros em viagens internacionais e nacionais são: Aeroporto Internacional de Viracopos/Campinas, Aeroporto Internacional de São Paulo/Guarulhos - Governador André Franco Montoro e o Aeroporto de São Paulo/Congonhas. O Aeroporto Internacional de São José dos Campos - Professor Urbano Ernesto Stumpf, atende principalmente o transporte de cargas e o Aeroporto de São Paulo/Campo de Marte opera com a aviação geral, executiva, táxi aéreo, escolas de pilotagem, assim como o Serviço Aerotático das Polícias Civil e Militar, tornando-se o aeroporto que abriga a maior frota de helicópteros dos Brasil (INFRAERO, 2017). A administração dos aeroportos é de responsabilidade da INFRAERO, parcial nos 
aeroportos de Guarulhos e o de Campinas, onde tem participação acionária minoritária e total nos demais aeroportos (INFRAERO, 2017).

\section{- Aeroporto Internacional de São Paulo - Guarulhos}

Inaugurado em 1985, na cidade de Guarulhos, Região Metropolitana de São Paulo, para atender aos passageiros dos voos comerciais internacionais, é administrado desde 2012 pelo consórcio formado pelas empresas Invepar e Airports Company South Africa (ACSA) que detém 59\% de participação acionária e a INFRAERO com $41 \%$ de participação nas ações. Para atender a demanda para viagens aéreas no país, o aeroporto passa por continuas transformações e seus resultados em 2017 podem ser observados na Tabela 1 (GRU AIRPORT, 2018)

Tabela 4.1 - Movimentação do Aeroporto Internacional de Guarulhos em 2017.

\begin{tabular}{|l|r|}
\hline Passageiros & $\mathbf{3 7 . 7 4 4 . 0 0 0}$ \\
\hline Pousos e Decolagens & 263.326 \\
Carga (toneladas) & 479.340 \\
\hline
\end{tabular}

Fonte: Compilado de GRU AIRPORT (2018); GRU AIRPORT CARGO (2017)

\section{- Aeroporto de São Paulo - Congonhas}

O aeroporto de Congonhas foi inaugurado em 1936, após o governo do Estado de São Paulo realizar um estudo técnico e verificar que a região da Vila Congonhas apresentava boas condições de visibilidade e drenagem. Desde 1990 configura-se como o aeroporto mais movimentado do Brasil e com a transferência de voos comerciais internacionais para o Aeroporto Internacional de São Paulo / Guarulhos, Congonhas passa a receber apenas internacionais da aviação executiva (INFRAERO, 2017). A movimentação do Aeroporto de Congonhas pode ser verificada na Tabela 4.2.

Tabela 4.2 - Movimentação do Aeroporto de Congonhas em 2017

Fonte: INFRAERO (2017)

\begin{tabular}{l|r}
\hline Passageiros & $\mathbf{2 1 . 8 5 9 . 4 5 3}$ \\
\hline Pousos e Decolagens & 217.918 \\
Carga (toneladas) & 35.981 \\
\hline
\end{tabular}

\section{- Aeroporto Internacional de Viracopos}

O Aeroporto Internacional de Viracopos está situado na cidade de Campinas, São Paulo, conhecida por abrigar grandes centros universitários, polo científico, tecnológico, industrial, com acesso às melhores rodovias do país e possui um grande parque industrial instalado na sua região metropolitana. A administração de Viracopos é realizada pelo 
Consórcio Aeroportos Brasil com 51\% de participação acionária e a INFRAERO com 49\% de participação acionária, após leilão promovido pelo governo federal. A concessão está prevista para 30 anos, divididas em cinco ciclos de investimentos. É o segundo principal terminal de cargas do Brasil, e com o crescimento e melhoria, o transporte de passageiros vem aumentando de maneira significativa (VIRACOPOS AEROPORTOS BRASIL, 2017). A atividade do aeroporto em 2017 pode ser observada na Tabela 4.3.

Tabela 4.3 - Movimentação do Aeroporto Internacional de Viracopos em 2017

\begin{tabular}{l|r}
\hline Passageiros & 9.332 .631 \\
\hline Pousos e Decolagens & 108.635 \\
Carga(toneladas) & 198.876 \\
\hline
\end{tabular}

Fonte: Viracopos Aeroportos Brasil (2017)

\section{- Aeroporto de São Paulo - Campo de Marte}

Localizado na Zona Norte da cidade de São Paulo, iniciou o seu funcionamento em 1920, com a construção da pista para atender a Escola de Aviação da Força Pública do Estado (INFRAERO, 2017). Hoje opera com aviação geral, executiva, taxi aéreo e escolas de pilotagem. O Aeroporto atende também o Serviço Aerotático das Polícias Civil e Militar. Sua administração é compartilhada pelo Comando da Aeronáutica e a INFRAERO e mesmo não possuindo linhas regulares, é um dos maiores em movimento operacional, principalmente de helicópteros (INFRAERO, 2017). Na Tabela 4 é possível verificar a movimentação ocorrida em 2017 neste aeroporto.

Tabela 4.4 - Movimentação do Aeroporto do Campo de Marte em 2017.

Fonte: INFRAERO, (2017)

\begin{tabular}{l|r}
\hline Passageiros & $\mathbf{1 1 8 . 9 8 4}$ \\
\hline Pousos e Decolagens & 69.137 \\
Carga (toneladas) & 0 \\
\hline
\end{tabular}

- Aeroporto Internacional de São José do Campos - Professor Urbano Ernesto Stumpf

Situado na Região do Vale do Paraíba, atende o transporte de carga para as indústrias locais. O tráfego de passageiros atende a demanda turística do Santuário de Nossa Senhora Aparecida, na cidade de Aparecida e as cidades do Litoral Norte de São Paulo (INFRAERO, 2017). No Tabela 4.5, é possível verificar a movimentação do Aeroporto de São José do Campos. 
Tabela 4.5 - Movimentação do Aeroporto Internacional de São José dos Campos em 2017

\begin{tabular}{l|l|r}
\hline Passageiros & $\mathbf{2 7 . 5 5 9}$ \\
\hline Pousos e Decolagens & 10.365 \\
Carga (toneladas) & 0 \\
\hline
\end{tabular}

Fonte: (INFRAERO, 2017)

\subsubsection{Aeronaves: Integridade do Produto e do Processo}

Aeronavegabilidade continuada consiste em um arranjo sistemático de ações para manter os níveis de segurança obtidos durante o processo de certificação de tipo do produto aeronáutico. O fluxo de processo da Aeronavegabilidade Continuada começa na certificação de tipo inicial, e continua na manutenção, na regulamentação operacional e aprovação obtida pela da Autoridade. Em outras palavras, significa manter a aeronave de acordo com seu projeto aprovado e estar em condições de operação segura (POSSI JÚNIOR; PASSOS; OLIVEIRA FILHO, 2010).

A abordagem do assunto aviação gera algumas dúvidas sobre sua abrangência. De acordo com a classificação explorada por Mistura e Silva Filho (2010), a aviação comercial implica na utilização da tecnologia aeronáutica e o seu emprego no transporte de pessoas e mercadorias; transporte aéreo é aquele que envolve todas as atividades de deslocamento de passageiros e cargas de um local para outro por via aérea e a aviação civil incorpora todo transporte aéreo comercial, aviação desportiva, agrícola excluindo as atividades aéreas militares.

Além disso, a Aviação Geral abrange todas as operações da Aviação Civil, excluindo os serviços aéreos regulares e não regulares que operam mediante remuneração ou locação. Abrange a aviação executiva, serviços aéreos, instruções, lazer e outros voos. A importância deste tipo de transporte ganha importância, principalmente em países com territórios vastos e de economia em desenvolvimento, assim como em áreas remotas e com poucas vias de acesso. Este meio de transporte atendem as atividades de operações empresariais, serviços aeromédicos, entre outros (CINTRA; MACHADO, 2016).

\subsubsection{Acidentes Aéreos}

Os acidentes no setor da aviação são extremamente raros e mais raros ainda são os acidentes fatais, porém o envolvimento de vidas humanas e na impossibilidade de zerar os acidentes aéreos, as companhias aéreas trabalham fortemente nas suas rotinas de operação uma vez que a segurança da aviação comercial depende de parcerias, troca de informações e normas globais (TYLER, 2014). A "International Air Transport 
Association" (IATA), entidade que reúne as 250 maiores companhias aéreas mundiais e responsáveis por $84 \%$ do tráfego aéreo global, divulgou em seu relatório de 2016 que foram registrados 65 acidentes com aeronaves de transporte de passageiros, sendo 10 acidentes com vítimas fatais, totalizando 268 fatalidades (JUNIAC, 2017). Com relação aos acidentes ocorridos no Brasil, é responsabilidade do "Centro de Investigação e Prevenção de Acidentes Aeronáutico" (CENIPA) investigar toda ocorrência com qualquer tipo de aeronave homologada com matrícula brasileira, o que inclui aviões de qualquer porte e tipo de atividade, helicópteros, planadores, ultraleves e aeronaves experimentais. Em 2014 ocorreram 115 acidentes, sendo 23 acidentes com vítimas fatais, totalizando 75 fatalidades. Deste total de acidentes 19,9\% aconteceram no estado de São Paulo (SANTOS; ALMEIDA; FARIAS, 2018). O último acidente aéreo registrado na aviação comercial brasileira com vítimas fatais em território nacional foi o avião da NOAR Linhas aéreas em 13 de julho de 2011, no aeroporto de Guararapes, em Recife, que caiu logo após a decolagem. Quando é feito um recorte de 10 anos, além do avião da NOAR, foram registrados o acidente do voo JJ3054 da TAM Linhas Aéreas em 17 de julho de 2007 no aeroporto de Congonhas em São Paulo, e o voo 1907 da Gol Linhas Aéreas Inteligentes em 29 de setembro de 2006 na rota Manaus-Brasília, totalizando 388 vítimas fatais (RIBEIRO, 2014). Cada operação de decolagem ou aterrissagem envolvem uma média de cento e quinze (115) passageiros e para atender o Regulamento Brasileiro da aviação Civil (RBAC) no 121, § 121.391, são necessários no mínimo três comissários para aeronaves com mais de 100 assentos e mais um comissário para cada grupo de cinquenta assentos ou parte. Cada um deles equipados com seus uniformes e treinados entre outras atribuições, para atuarem em emergências com fogo a bordo. De acordo com as informações estatísticas da ANAC em 2017 ocorreram nos aeroportos paulistas 669.381 operações, envolvendo no mínimo 1.800 .000 aeronautas que podem ser beneficiados com a melhoria do material de seus uniformes, tornando o combate de fogo a bordo mais seguro e eficiente, contribuindo para as ações de segurança na aviação comercial.

A coleta de informação durante a análise de acidentes contribui para o desenvolvimento das rotinas de prevenção. Trata-se da identificação de riscos e ocorrências através da coleta de dados e da sua análise (WILKE; MAJUMDAR; OCHIENG, 2014).

Devido à grandeza e ao alcance do setor de transporte aéreo, a segurança é caracterizada como um elemento chave e na busca de melhorias, as empresas aéreas 
passam por uma abordagem proativa, o qual utiliza monitoramento diário de voo, identificando os riscos envolvidos e antecipando as ações de segurança (LI et al., 2016).

O impacto das abordagens de segurança é refletido no Global Accident Rate. Este índice mostra que o número de acidentes por milhão de decolagens. O resultado em 2016 foi de 1,61 acidentes por milhão de decolagem (JUNIAC, 2017).

\subsection{ATRIBUIÇÕES DOS AERONAUTAS}

A presença feminina na aviação inicialmente foi vista como excentricidade com os voos de Amelia Earhart nos anos de 1930 e totalmente rejeitada em 1934 quando os pilotos masculinos associados à Airline Pilots Association (ALPA) encerraram a carreira de Helen Richey, a primeira mulher piloto documentada, que trabalhou apenas um ano para a Central Airline. Esta restrição para a contratação de mulheres piloto nos Estados Unidos perdurou até a década de 1970 (WHITLEGG, 2007).

No imaginário popular o avião era mais que um marco no progresso tecnológico, mas sim um catalisador para uma nova sociedade utópica, democracia pelo mundo e a paz mundial. Era vista como uma atividade para aventureiros (VANTOCH, 2013).

A primeira função dos voos era o transporte de correspondências com aviões sem pressurização ou isolamento acústicos (NERY, 2009). Caso houvesse um passageiro ocasional, a experiência de voo era desconfortável, ocupando um lugar sobre os malotes. O conjunto de itens de segurança disponíveis era composto de capacete, óculos de segurança e paraquedas (NERY, 2009; WHITLEGG, 2007).

Acompanhando o sucesso e da exposição midiática do voo solo atravessando o Atlântico de Nova Iorque à Paris, completado por Charles Lindbergh em 1927, houve um aumento no interesse pela aviação e os mais descrentes começaram a pensar na real possibilidade em realizar suas viagens voando. Várias empresas aéreas se estabeleceram nos Estados Unidos no período de 1927 a 1929 e contratavam homens como atendentes de bordo, conforme o modelo já utilizado na Europa (WHITLEGG, 2007).

\subsubsection{Profissão de comissário de voo e suas atribuições}

Ellen Church, nascida em 1904, cresceu em um momento especial da aviação. Os modelos e testes iniciais reforçavam o fascínio pelos voos, algo muito diferente para as pessoas. $\mathrm{O}$ ato de voar expressava sentimentos muito diferentes, passando pela descrença total até a certeza do sucesso absoluto dos inventores americanos. Naquele contexto, 
Ellen Church vai até o escritório da Boeing Air Transport e se encontra com Steve Stimpson (VANTOCH, 2013).

No momento da abordagem de Ellen Church sobre conseguir um emprego na aviação, ela conta sobre a sua habilidade em pilotar um avião, mas ciente de que as companhias aéreas eram bastante resistentes à contratação de mulheres piloto (NERY, 2009).

Naquele momento, Steve Stimpson estava desenvolvendo o processo para criar uma sensação de conforto e cuidado a bordo dos voos com a utilização de um maître ou mordomo e redesenhando suas cabines para torná-las mais familiar para quem usava o transporte sobre trilhos (WHITLEGG, 2007).

A competição pelos passageiros não era entre as companhias aéreas, mas sim com as companhias ferroviárias, que já tinham seus serviços bem estabelecidos, ofereciam segurança e faziam parte da cultura americana para viagens de longa distância (NERY, 2009). Os tempos de voo ainda eram longos, pouco menores que o tempo da viagem de trem e como descrito anteriormente, sem conforto (WHITLEGG, 2007).

Church então a sugere Stimpson que a Boeing contrate enfermeiras formadas como atendentes de cabine durante o voo, criando um efeito psicológico positivo sobre os passageiros. (VANTOCH, 2013; WHITLEGG, 2007).

O primeiro requisito para se candidatar ao cargo de atendente de cabine era ser enfermeira registrada. Outros critérios de seleção exigiam candidatas solteiras, no máximo 25 anos de idade, altura máxima de 1,60 m e peso máximo de 52 quilos devido às dimensões da cabine (NERY, 2009).

Na abordagem de Vantoch (2013), as empresas aéreas contratavam enfermeiras como comissárias de voo, pois preenchiam a necessidade da indústria que estava nascendo em refletir a imagem respeitável de mulher trabalhadora da década de 1930. A Imagem das enfermeiras transmitia trabalho duro, cuidado com as pessoas e disciplina.

Em 1931 Ellen Church, já funcionária da Boeing desenvolve a descrição do trabalho e o programa de treinamento para as comissárias de voo, descrevendo suas atribuições que incluía limpar as cabines, aquecer o café, fazer relatórios de passageiros e equipamentos, verificar os tíquetes, cuidar dos passageiros enjoados, arrumar os travesseiros, material de leitura, cigarros e goma de mascar. Também ajudavam com a bagagem, reabastecer os aviões e empurrar as aeronaves para o hangar (VANTOCH, 2013). 
Atualmente, a presença dos comissários de bordo vai muito além de suas atribuições de cuidar e servir aos passageiros. Eles são profissionais de segurança de voo e muitas vezes a única interação física entre o cliente e a companhia aérea (NERY, 2009). Os aeronautas tem a particularidade em sua função que é o treinamento de combate às emergências de fogo a bordo (FEDERAL AVIATION ADMINISTRATION, 2018), em um ambiente restrito em que a ação deve ser muito rápida e assertiva.

\subsubsection{Início da profissão de comissários de voo no Brasil}

No Brasil a aviação de iniciativa privada tem sua exploração concedida pelo governo federal em 1927 para duas empresas estrangeiras, a Condor Syndikat e a Aèropostale de origem francesa (MALAGUTTI, 2001).

Também em 1927 a Viação Aérea Rio-Grandense - VARIG e a Sindicato Condor, produto nacionalizado da Condor Syndikat, registram-se como empresas de aviação e obtém suas concessões para operação de suas linhas. A VARIG realiza o seu voo inaugural de Porto Alegre a Pelotas. Somente evolui com a compra de aviões excedentes de guerra após o final da Segunda Guerra Mundial. (NERY, 2009).

A Sindicato Condor, devido às restrições governamentais com empresas de origem alemã durante a Segunda Guerra Mundial, realiza a troca de nome para Serviços Aéreos Cruzeiro do Sul (MALAGUTTI, 2001).

A VARIG e a Sindicato Condor, eram as duas empresas aéreas nacionais oficializadas no ano de 1927. O Brasil, na aviação, equiparava-se como pioneiro junto aos demais países na formação da frota internacional (OLIVEIRA, 2011).

Em meio à abertura de nova rota para os Estados Unidos, na qual novas aeronaves passariam a ser utilizadas, começa a surgir à necessidade de novos profissionais para $\mathrm{o}$ atendimento dos passageiros e segurança de voo (CASTELLITTI, 2014).

Sempre à frente em suas operações, a VARIG inicia em 1954 o recrutamento de mulheres para a função de comissárias de bordo para seus voos internacionais. A frota seria reforçada por modelos Constellation e a decisão por contratar mulheres veio do presidente da companhia Ruben Martim Berta, para atender com maior elegância o público feminino, em voos longos, em poltronas-leito, muitas vezes com os passageiros usando pijamas (CASTELLITTI, 2014).

\subsubsection{Treinamento e qualificação}

O Manual de Normas da IATA - International Air Transport Association (2015) define a função dos comissários de bordo da seguinte forma: 


\begin{abstract}
"O comissário de bordo é designado para realizar tarefas de segurança na cabine de passageiros de acordo com os requerimentos do operador e da Autoridade; qualificado para realizar as funções da cabine em situação de emergência e decretar procedimentos para garantir a segura e ordenada evacuação dos passageiros quando necessário."
\end{abstract}

As atividades laborais exercidas pelos comissários de voo são inúmeras. Além do serviço de bordo, que é sua atividade mais conhecida pelos passageiros, existem funções relacionadas à segurança do voo que são desempenhadas pelos comissários, quase sempre de forma discreta ou oculta aos olhares dos passageiros (FLIGHT ATTENDANT MANUAL, 2014).

Os integrantes da tripulação incluindo os comissários de bordo devem passar por um processo de qualificação para a obtenção de licença específica para o exercício da profissão (IATA, 2015).

No Brasil, a carreira dos comissários de voo se inicia em uma escola de preparação de pessoal para aviação civil brasileira, que deve ser regulamentada pela RBHA-141 Escolas de Aviação Civil. A escola dever obter o certificado de autorização para o funcionamento e homologação dos cursos ao DGAC - Diretor- Geral do Departamento de Aviação Civil (AGÊNCIA NACIONAL DE AVIAÇÃO - ANAC, 2016b).

Após ser aprovado no teste de conhecimento com avaliação superior a 70\%, e receber o Certificado de Capacidade Física (CCF), o candidato deve solicitar sua Licença e Certificado de Habilitação técnica, pois nenhuma pessoa pode trabalhar como comissário de voo sem tais acreditações (AGÊNCIA NACIONAL DE AVIAÇÃO ANAC, 2006).

As escolas de aviação civil homologadas devem ministrar curso para a cobertura dos requisitos de conhecimento teórico que serão testados para a obtenção da Licença e do CHT (Certificado de Habilitação Técnica), devidamente descritos no RBHA-63 Requisitos para a concessão de licenças de Mecânico de Voo e de Comissário de voo (2006), em sua subparte C - Comissário de Voo (Anexo A), Seções 63.67- Requisitos de Conhecimento, os quais entre outros assuntos abordados estão a regulamentação aeronáutica, aspectos fisiológicos e psicológicos da atividade dos comissários, emergência, etc. Também a seção 63.69 - Requisito de Experiência e Treinamento que trata de validar as horas de voo dos comissários e a seção 63.71 - Requisitos de Perícia que se trata da verificação de competência aplicada pelos inspetores da aviação civil ou examinadores credenciados. 
Após a obtenção da Licença e do CHT o comissário de voo está apto para atender a demanda de pessoal das companhias aéreas e deve portar tais documentos sempre que estiver exercendo a sua atividade e apresentá-los para inspeção, caso requerido (AGÊNCIA NACIONAL DE AVIAÇÃO - ANAC, 2006).

Anualmente, os comissários de voo passam por treinamentos de emergência e evacuação da aeronave, além de primeiros socorros e combate ao fogo. O Comandante, que representa a maior autoridade a bordo, é o principal responsável pela segurança do voo e os comissários se reportam a ele. De acordo com a RBAC - 121 - Requisitos operacionais: Operações Domésticas, de bandeira e suplementares, o comandante também deve verificar o uniforme e a identificação pelo crachá na apresentação da tripulação para o voo (AGÊNCIA NACIONAL DE AVIAÇÃO - ANAC, 2010).

\subsubsection{Uniformes}

O uso do uniforme pelos funcionários de uma empresa é um fato corriqueiro, objetivando organização do trabalho, apresentação da empresa junto ao público, a imagem corporativa e seus objetivos comerciais. Também, desde que conste do contrato de trabalho, o uso do uniforme pode ser obrigatório (B_FONSECA, 2014).

Nesse contexto, o uniforme carrega em si as funções práticas, as quais correspondem às características estruturais, materiais, métodos de confecção, cores e modelos, assim como as funções diacríticas, que são propriedades distintivas dos uniformes com uso de modelos diferenciados, brasões ou sinais, possibilitando a visualização da hierarquia. Por fim as funções simbólicas, as quais representam os valores, princípios, expectativas, produção de sentidos e representações que recaem sobre o usuário do uniforme (ALMEIDA, 2003; EL SARRAF, 2004; FARIAS, 2010).

Uma definição para uniforme o trata como uma vestimenta com denotação de aparência similar, distinção do grupo ou uniformidade. Entretanto eles dizem muito mais. A função dos uniformes através de seu delineamento de hierarquia, status, autoridade e valores também carrega a representação daquilo que não é permitido realizar quando o indivíduo estiver vestido com o uniforme. O uniforme passa a ser um indicador da codificação de regras de condutas apropriadas e sua internalização (CRAIK, 2007).

Para Almeida (1999), a substituição de mercenários na formação de tropas europeias demandou a concepção de indumentárias e equipamentos com características homogêneas, período em que o termo uniforme começa a ser utilizado para este tipo de 
vestuário. Uma característica dos uniformes, em especial é a sua detalhada regulamentação.

Historicamente os operários brasileiros passaram pela uniformização sob as ideologias do governo ditatorial de Getúlio Vargas. Os operários uniformizados da Companhia Siderúrgica Nacional (CSN) faziam parte da campanha "soldado operário", que exigia dos operários em seus macacões de serviço, todo o esforço para promover o país em tempos de guerra. Este modelo segue até o final da década de 1980, quando se inicia a abertura econômica, a concorrência globalizada e as empresas buscam agregar mais valor à sua imagem empresarial (FARIAS, 2010).

O valor simbólico de um uniforme pode ser observado no estudo antropológico de Farias (2010), que aborda o comportamento dos usuários do uniforme da USIMINAS e o tratamento social percebido pelos habitantes de Ipatinga - MG, sede da empresa. Adotado na década de 1970 para equilibrar as tensões entre os operários semianalfabetos e os engenheiros, sutilmente a empresa criou benesses para quem usava o uniforme para chegar à empresa e após o expediente. Facilidades de crédito e a percepção da adoção total dos princípios éticos da empresa transferiam ao usuário do uniforme cinza, o status de provedor, bom pagador e até boa opção para casamento.

Do ponto de vista da legislação, a Norma Reguladora - NR 6 (BRASIL, 2015), não relaciona o uniforme como Equipamento de Proteção Individual (EPI), pois possuem apenas características de uniformização e padronização dos funcionários e não são direcionados para proteger os trabalhadores de acidentes ou exposição a agentes nocivos.

Ademais, existem profissões em que as vestimentas de trabalho são regulamentadas para atender as condições de segurança como um equipamento de proteção individual, específico e adequado às atividades envolvidas. Exemplos de vestimentas regulamentadas são os uniformes dos eletricitários, que de acordo com a Norma Reguladora NR 10 (BRASIL, 2016a) estabelece que as vestimentas devam ser adequadas às atividades, e contemplar a condutibilidade, inflamabilidade e influências eletromagnéticas. Mais recentemente, em uma alteração na Norma Regulamentadora NR 9 (BRASIL, 2016b) os funcionários de Postos Revendedores de Combustível conquistaram o direito de receber de forma gratuita, uniformes adequados aos riscos do ambiente laboral. Os postos também ficarão responsáveis pela higienização dos uniformes e deixar a disposição dos funcionários conjuntos de uniformes extras, para a troca em situações de contaminação por benzeno. 
A uniformização pode refletir a imagem que a empresa deseja transmitir (EL SARRAF, 2004) e as empresas atuais, buscam cores, tendências inovadoras, estampas e modelos para simbolizarem seus valores nos uniformes de suas equipes, inclusive com a participação de estilistas nacionais e internacionais no desenvolvimento de suas coleções de uniformes (RUBBO, 2012). Os critérios para a seleção dos uniformes estão se modificando, passando pela abordagem estética e padronizante e seguindo para a funcionalidade, segurança e conforto de quem vão usá-lo (EL SARRAF, 2004).

As roupas profissionais geralmente são feitas de poliéster e suas misturas com algodão. Trata-se de um material relativamente barato para a indústria de vestuário, proporcionando o conforto e a respirabilidade do algodão, com a força e durabilidade do poliéster (LEISTNER et al., 2015). Entretanto estas fibras e misturas apresentam baixa estabilidade térmica e alta inflamabilidade (ATTIA; MORSY, 2016).

As empresas aéreas de todo o mundo adotam o uniforme para a apresentação pessoal de seus tripulantes. Entende-se por tripulação a equipe que trabalha a bordo da aeronave e é composta por pilotos (comandantes e copilotos) e comissários de voo (chefe de Cabine e comissários auxiliares).

De acordo com a Resolução 121 - Requisitos operacionais: Operações Domésticas, de bandeira e suplementares (ANAC, 2010), o comandante deve verificar o uniforme e a identificação pelo crachá na apresentação da tripulação para o voo.

Um exemplo de uniforme recebido pelas comissárias de voo pode ser observado na Figura 1, que mostra as novas peças que a companhia Gol Linhas Aéreas lançou em 2014 para tripulação e pessoal de terra, com grande divulgação na imprensa. O conjunto completo para as comissárias de voo é composto por: camisa de manga curta, saia, vestido, camisa de manga longa, calça, cardigã tipo cachecouer, blazer, lenço, cinto, meias, sapatos e sapatilha (GALLO, 2014).

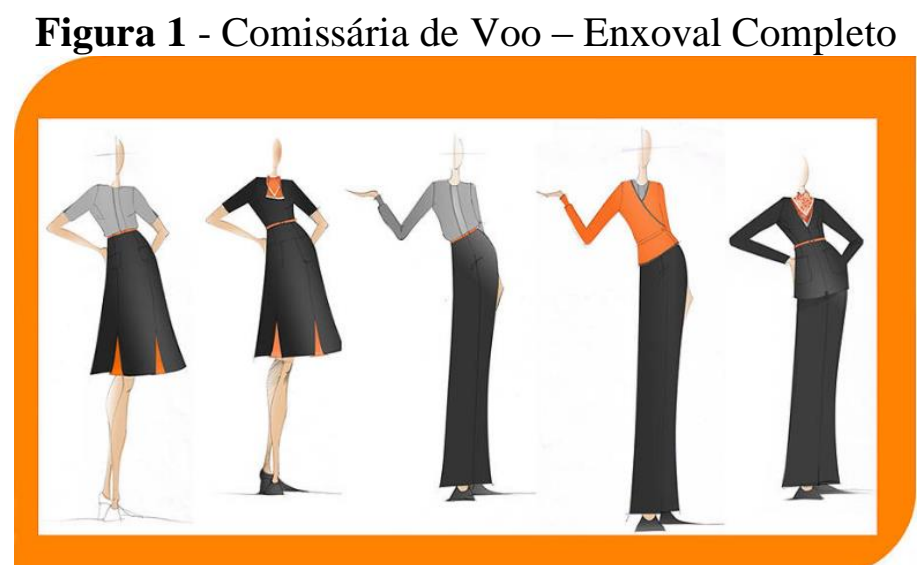

Fonte: Gallo (2014) 
A portaria n॰ 6 de 7 de janeiro de 1963 do Ministério de Trabalho e Emprego (BRASIL, 1963), obriga as empresas de aviação civil a fornecer aos seus funcionários, sem ônus para os mesmos, as peças de uniforme em quantidade necessária para cumprimento de suas tarefas, com durabilidade variando de seis meses a dois anos, dependendo da peça e do prazo determinado para troca.

Ao receberem o seu conjunto de peças de uniforme, a imagem do comissário passa a ser a marca da empresa. Neste contexto, os funcionários são vistos como representantes das Linhas Aéreas, pois causam a primeira impressão percebida pelos clientes. As empresas aéreas estabelecem normas criteriosas e detalhadas sobre postura pessoal dirigida aos seus funcionários para quando estiverem usando o uniforme (UNITED, 2013).

São regras que vão desde a combinação das peças, questões de higiene, cor de cabelo e até a conduta pessoal do comissário enquanto estiver usando o uniforme. Também são destacadas as regras para descarte das peças usadas, com orientação para cortar qualquer identificação que possa relacionar o uniforme à Linha Aérea. Os uniformes não podem ser vendidos em loja físicas ou virtuais e nem distribuídos para quaisquer pessoas de fora da empresa, sem a devida autorização (QUATAR, 2007).

\subsection{MATERIAL TÊXTIL}

\subsubsection{A Cadeia Têxtil}

A indústria têxtil e de vestuário do Brasil, posiciona-se globalmente de forma representativa como produtor têxtil. De acordo com as informações da Associação Brasileira da Indústria Têxtil (ABIT), o setor apresentou em 2016 um faturamento de US\$ 45 bilhões, contando com 1,5 milhões de empregos diretos dos quais, 75\% foram ocupados por mulheres (ASSOCIAÇÃO BRASILEIRA DA INDUSTRIA TÊXTILE DE CONFECÇÃO, 2017a).

Trata-se de um setor relevante para a economia brasileira, sendo o segundo maior gerador do primeiro emprego. Fazendo um recorte na indústria de transformação, o segmento de têxtil e vestuário é o segundo maior empregador, responsável por 16,7\% das vagas ocupadas e 5,7\% do faturamento deste segmento. Trata-se de uma extensa e complexa cadeia (Figura 2). 
Figura 2 - Estrutura da Cadeia produtiva e de distribuição Têxtil e Confecção

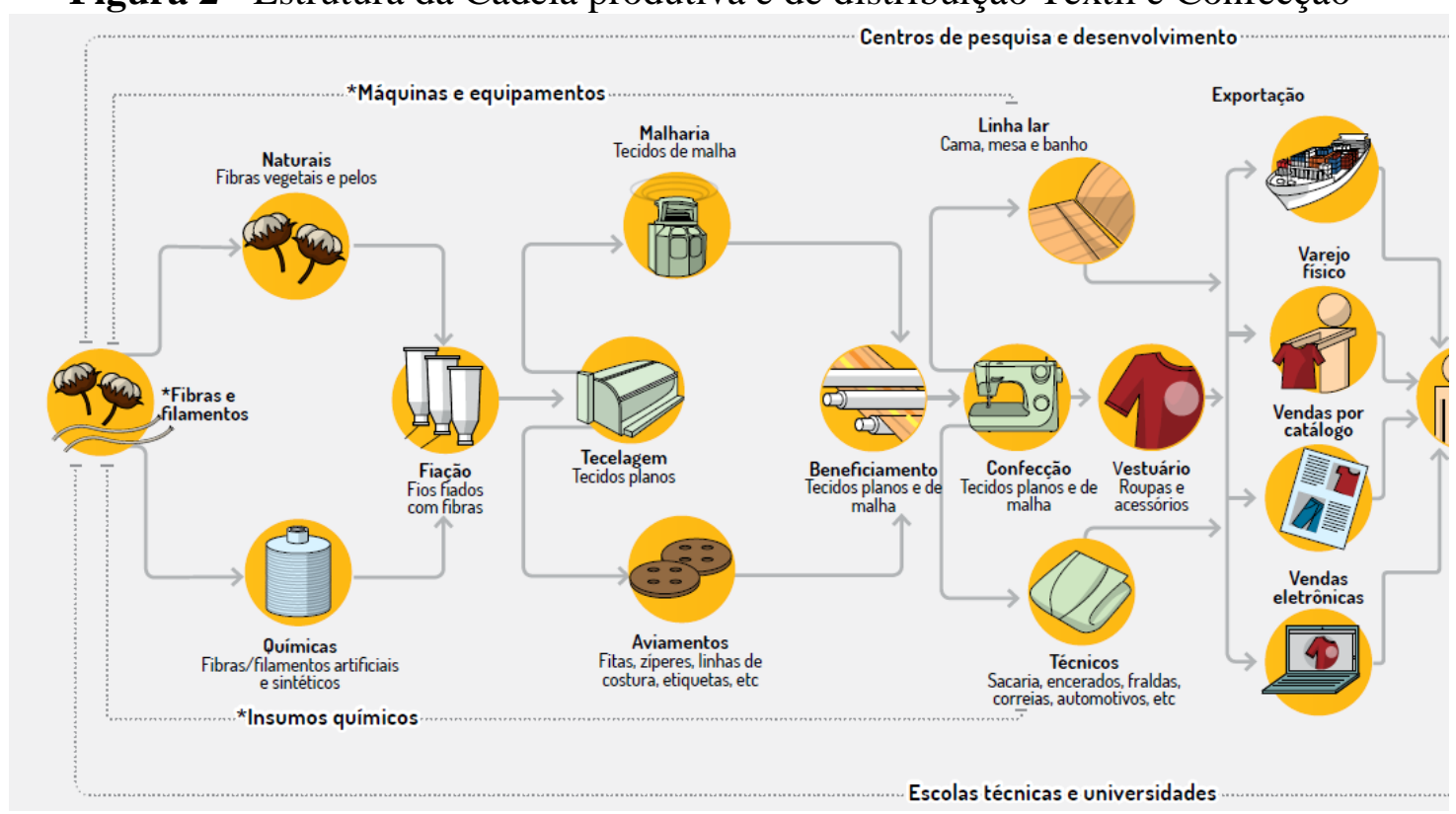

Fonte: ABIT - Associação Brasileira da Indústria Têxtil e de Confecção (2017b)

De forma simplificada, o processo se inicia com a obtenção das fibras. Para as fibras naturais, existe o caminho do cultivo das espécies vegetais ou da criação de animais. Para as fibras manufaturadas, o processo de obtenção é realizado na indústria química. Em seguida, as fibras obtidas passam pelo processo de fiação para a obtenção do fio, tecelagem para a obtenção do tecido plano ou malha. Caso necessário, segue para o beneficiamento que visa melhorar as características físico-químicas do tecido. $\mathrm{O}$ material é enviados para confecção das peças de vestuário as quais chegam ao consumidor final (FEDERAÇÃO DAS INDÚSTRIAS ESTADO MINAS GERAIS, 2014; LOPES, Guilherme Bretz; FREIRE, 2013).

Como caracterizam os autores Bastian e Rocco (2009) e FIEMG (2014) em seu Guia Técnico Ambiental da Indústria Têxtil as principais etapas da indústria têxtil e de confecção em seu processo são demonstradas na Quadro 1. 
Quadro 1 - Etapas da Cadeia Têxtil

\begin{tabular}{|c|l|}
\hline Processo & Atividade \\
\hline Fiação & $\begin{array}{l}\text { Transformação das fibras em fios. As propriedades das fibras } \\
\text { definem o processo de fiação e o título (dimensão relacionada ao } \\
\text { diâmetro do fio) definindo o conjunto de operações necessárias } \\
\text { para a produção. Pode ser enviado para o beneficiamento ou } \\
\text { diretamente para tecelagem ou malharia. }\end{array}$ \\
\hline Tecelagem & $\begin{array}{l}\text { Tecido plano é uma estrutura com entrelaçamento de fios em } \\
\text { estruturas lineares, utilizando teares de pinça, de ar ou de água, etc. }\end{array}$ \\
\hline Malharia & $\begin{array}{l}\text { O tecido de malha é formado por laçadas e fios, utilizando teares } \\
\text { circulares ou retilíneos. }\end{array}$ \\
\hline Beneficiamento & $\begin{array}{l}\text { Processos parra melhorar as características dos substratos têxteis de } \\
\text { acordo com a especificação do produto final. Alguns exemplos são } \\
\text { a desengomagem, tingimento, estamparia, impregnação, } \\
\text { amaciamento, etc. }\end{array}$ \\
\hline
\end{tabular}

Fonte: Adaptado de ABIT - Associação Brasileira da Indústria Têxtil e de Confecção (2017b)

Na cadeia produtiva têxtil do Estado de São Paulo, verifica-se a distribuição das indústrias têxteis e de confecção organizadas em polos têxteis, que agregam várias cidades e têm características bem definidas, como por exemplo, a Região de Americana (com uma cadeia têxtil integrada desde fibras até confecção), passando pela Região das Águas, (voltada à malharia retilínea), chegando à Região de São Paulo, Zona Leste e Zona Sul, com foco nas confecções e exploração do uso de marcas (BASTIAN; ROCCO, 2009).

Uma grande segmentação desta cadeia é a indústria de confecção ou de vestuário, caracterizando-se pela massiva utilização de mão de obra, fazendo um contraponto com o baixo aporte financeiro necessário para se iniciar a operação do negócio (LOPES, Guilherme Bretz; FREIRE, 2013). Some-se a isto a característica de terceirização das etapas de produção por outras empresas, sendo que essas oficinas de costura são instaladas em locais pequenos, muitas vezes improvisados nas residências dos proprietários para prestarem os serviços necessários às grandes confecções (BASTIAN; ROCCO, 2009).

\subsubsection{Fibras Têxteis}

As fibras se apresentam como a principal matéria-prima para os diversos materiais têxteis disponíveis para uso. São os insumos da fiação, onde são transformadas em fỉos e posteriormente utilizadas na tecelagem de forma manual e artesanal ou industrial (COOK, 2001). Constituem a base para todos os produtos têxteis e podem ser de origem natural 
ou manufaturada (Figura 3) (LORD, 2003). Também podem ser separadas por sua origem química: celulósicas, proteicas, poliamida, poliéster, poli vinil (acrílico) e poliolefinas (polipropileno), etc. (HEARLE, 2009).

Figura 3 - Classificação das fibras têxteis.

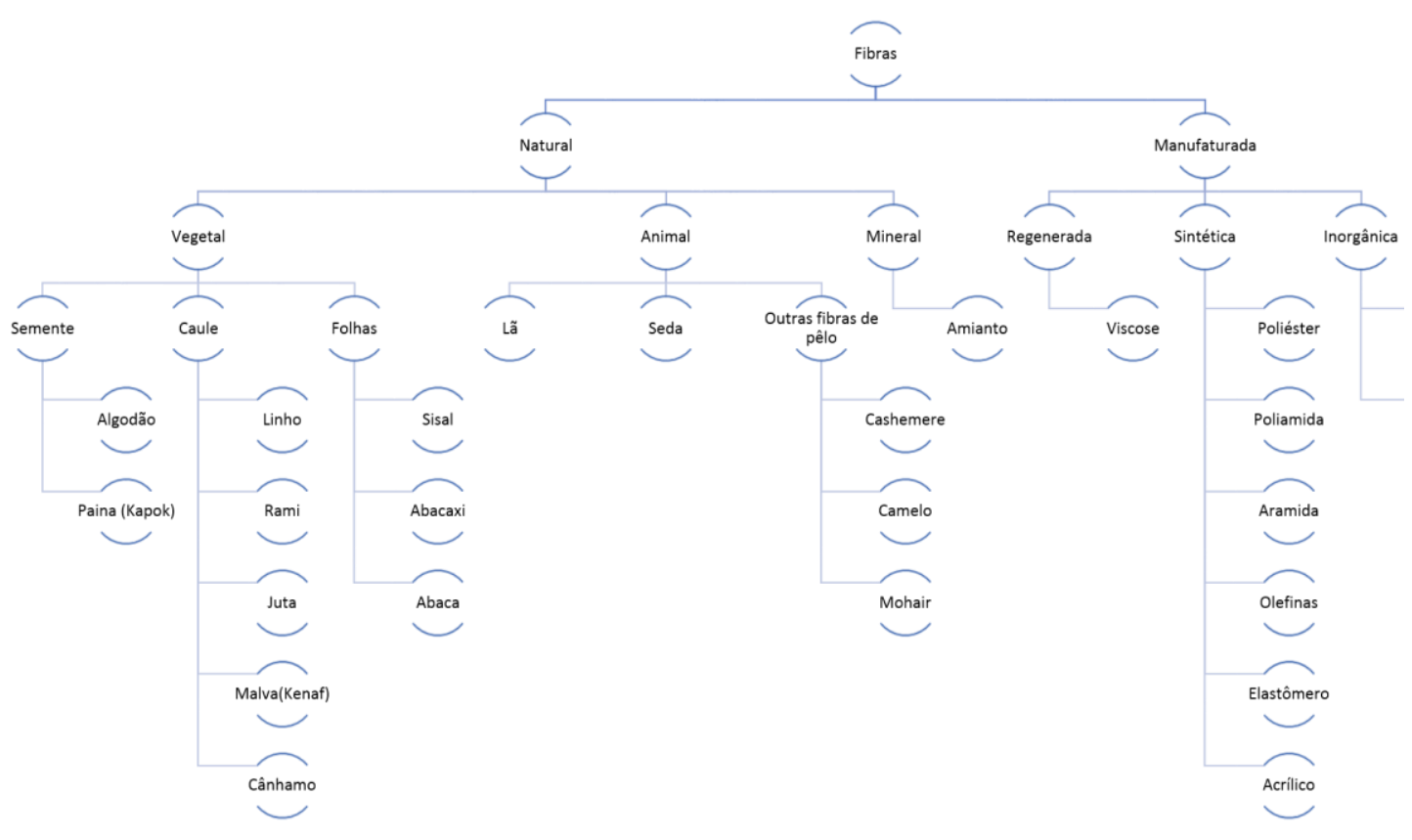

Fonte: Adaptado de Lord (2003)

A história da humanidade apresenta muitas referências sobre os materiais têxteis, pois foram e ainda são os componentes dos tecidos usados para cobrir e proteger os corpos (LADCHUMANANANDASIVAM, 2006; HEARLE, 2009). Até o século XVII as principais fibras utilizadas nas produções domésticas eram as de origem natural, como a lã, o algodão, a seda, o cânhamo e o linho. A primeira fibra manufaturada, chamada de fibra de celulose regenerada (raiom ou raiom viscose), foi desenvolvida no final do século $\mathrm{XIX}$, mas apenas no século $\mathrm{XX}$ a teve início a sua produção industrial. $\mathrm{O}$ desenvolvimento das fibras químicas com base nos produtos derivados de petróleo iniciou-se no final da década de 1930 e a produção industrial começou durante a Segunda Guerra Mundial (LORD, 2003).

As principais características da fibra como a matéria-prima têxtil são a sua flexibilidade, finura e grande razão entre comprimento e finura (HEARLE, 2009). Assim a definição da fibra é um material de espessura diminuta em relação ao seu comprimento, flexível e de diâmetro de 10-20 $\mu \mathrm{m}$, podendo chegar a $50 \mu \mathrm{m}$. A média de diâmetro para fibra da seda é de 10 a $13 \mu \mathrm{m}$ e para a lã até $40 \mu \mathrm{m}$. As fibras sintéticas podem ser produzidas desde diâmetros de $6 \mu \mathrm{m}$ (microfibras) até fibras para aplicações pesadas 40 
$\mu \mathrm{m}$, como, por exemplo, para carpetes. Para cada aplicação as fibras precisam de uma combinação de força e estabilidade (LORD, 2003).

\subsubsection{Propriedades das Fibras Têxteis}

As fibras têm várias propriedades físicas, químicas e mecânicas, cada qual com a sua importância, visando possíveis aplicações. Entender tais aspectos proporcionam assertividade na escolha da melhor matéria-prima para o produto têxtil final. O Quadro 2 indica a categorização de algumas propriedades das fibras relacionadas ao seu desempenho, que serão detalhadas em seguida (ELMOGAHZY, 2009a; SINCLAIR, 2015).

Quadro 2 - Propriedades das Fibras Têxteis

\begin{tabular}{|c|c|}
\hline Categoria & Propriedade \\
\hline Dimensional & $\begin{array}{l}\text { Comprimento } \\
\text { Finura } \\
\text { Secção transversal } \\
\text { Título }\end{array}$ \\
\hline Mecânica & Tração e alongamento \\
\hline Absorção & Recuperação de umidade - Regain \\
\hline Química & $\begin{array}{l}\text { Resistência alcalina } \\
\text { Resistência ácida } \\
\text { Resistência a agentes oxidantes }\end{array}$ \\
\hline Térmica & $\begin{array}{l}\text { Condutividade } \\
\text { Amolecimento e derretimento } \\
\text { Combustibilidade } \\
\text { Decomposição }\end{array}$ \\
\hline
\end{tabular}

\subsubsection{Propriedades Dimensionais das Fibras}

\section{- Comprimento}

O comprimento é um fator importante na avaliação do valor comercial de uma fibra. As maiorias das fibras naturais são de comprimento limitado, variando de milímetros a centímetros. A seda é uma exceção, que pode apresentar filamentos de até 2000 metros. Fibras sintéticas são produzidas como filamentos contínuos, os quais podem ser usados como tal ou cortados em fibras mais curtas para fiação por processos similares aos usados na fiação de fibras naturais cortadas, como o algodão ou a lã (COOK, 2001). Por serem contínuos, os fios de filamento podem ser feitos com pouca ou nenhuma torção, produzindo uma aparência lisa e brilhante, particularmente quando não há crimpagem (também chamada de ondulação) (SINCLAIR, 2015). 
Em geral um comprimento de fibra (notadamente natural) mais longo proporciona vantagens em seu processamento, necessidade de menor quantidade de fibras por comprimento de fio e um fio de maior resistência produzido com o mesmo nível de torção, gerando um fio mais suave (SAVILE, 2002). As fibras naturais ou staple (cortadas no caso das químicas) precisam ser torcidas para formar o fio fazendo com que as fibrilas da superfície da fibra se entrelacem umas com as outras de forma coesa. A coesão é um fator importante na fiação bem-sucedida de fibras cortadas e pode produzir fios muito fortes.

Os comprimentos das fibras naturais, bem como a sua finura, não são constantes. Para cada tipo de fibra de origem animal ou vegetal, existe uma média de valores de comprimento aceitáveis. A definição do comprimento das fibras é feita para cada lote através da análise de uma amostra. As fibras artificiais, por outro lado, podem ser cortadas durante a produção com qualquer comprimento que seja necessário. Desta forma, quando fibras naturais e artificiais são misturadas, todas as fibras apresentam o mesmo comprimento ou diferentes comprimentos misturados em proporção conhecida (SAVILE, 2002).

\section{- Finura}

Uma característica das fibras é a finura, que se refere à espessura (COOK, 2001). As fibras mais finas, com menor espessura, apresentam uma grande razão entre a superfície e o peso e são muito flexíveis. A finura na indústria têxtil é medida de várias formas, escolhida a partir do elemento que se quer medir, podendo ser fibra, fio ou tecido (SINCLAIR, 2015).

A finura é uma das propriedades importante das fibras, pois a sua escolha se reflete nos produtos têxteis, nos efeitos nas propriedades do fio e, portanto, no tecido que é feito a partir dele. Quanto mais fina a fibra, mais fino será o fio que pode ser fiado. Fibras muito finas são mercadorias altamente valorizadas. Para os materiais naturais tais como o algodão, a seda, a lã e outras fibras de origem animal, as variedades mais finas são reservadas para o vestuário mais caro e, portanto, com de preços mais elevados. A finura da fibra afeta a forma como ocorre o drapejamento e a maciez percebida em contato com a pele do usuário (SAVILE, 2002). Também pode ser medida de duas formas, sendo uma aplicada às fibras de lã ou pelo de animais que apresentam secção transversal com formato próximo a um círculo, pode-se considerar o diâmetro da fibra de uma amostra e fazendo a média em mícron $(\mu \mathrm{m})(\mathrm{COOK}, 2001)$. 


\section{- Secção Transversal}

As fibras fundidas mais simples são extrudadas através de uma fieira circular, gerando uma fibra com secção transversal circular. A utilização de fieiras mais trabalhadas permitiu a fabricação de filamentos com diferentes formatos de secção transversal. A lã tem a sua secção ligeiramente elíptica, embora alguns fios, quando vistos em escalas maiores e com maior resolução é possível determinar o perímetro. A seda tem uma secção transversal triangular e o algodão têm uma forma característica de "dog bone" ou feijão (MORTON; HEARLE, 2009b).

As fibras naturais apresentam uma variedade de formas, enquanto as fibras sintéticas podem ser fabricadas em quase qualquer formato para atender as especificações solicitadas no projeto. Alguns tipos comuns de seção transversal de fibra são: circular, "dog bone", o trilobal, multilobal e serrilhado e oco ilustrados na Figura 4. Embora exista uma maior flexibilidade na seleção e produção de uma determinada secção transversal para fibras manufaturadas, algumas tendem a ter a mesma forma básica, principalmente redonda ou serrilhada (SINCLAIR, 2015).

Figura 4 - Secção Transversal das fibras. (a) Circular, (b) "dog bone", (c) Trilobal, (d) Multilobal, (e) Serrilhado, (f) Oco.

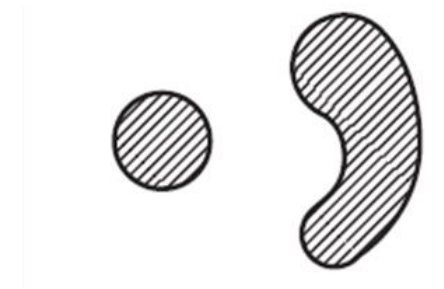

(a) (b)

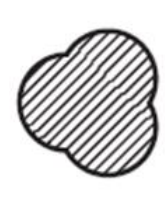

(c)

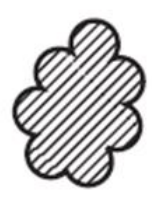

(d)

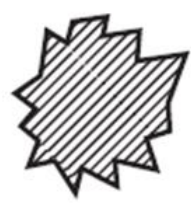

(e)

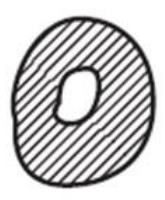

(f)

Fonte: Adaptado de Sinclair (2015)

\section{- Título de fibras e fios}

Para os materiais têxteis, uma medida mais útil do que a dos diâmetros de fibras e fios, é densidade linear (ou título), em termos da massa por unidade de comprimento (HEARLE, 2009).

Trata-se da mensuração estimada do diâmetro. A unidade primária é o tex que representa o peso em gramas para 1.000 metros de fibra ou fio. As variações decimais são o dtex para o peso em gramas de 10.000 metros de fibra e o militex para o peso em miligramas para 1.000 metros de fibras. Quando aplicado aos filamentos, tais como a seda ou fibras sintéticas, o título é expresso em tex ou denier. O denier representa o peso em gramas de 9.000 metros de fibras ou fios (LORD, 2003). 
Para medir a massa por unidade de comprimento de fibras, um grande número de fibras ou fios devem ser cortados com precisão, em comprimentos curtos e pesados em uma balança sensível a pequenas variações de massa. Portanto, para um mesmo material, havendo seu comprimento de fibra ou fio conhecido, sua massa estará diretamente relacionada com a área de sua secção transversal. (SAVILE, 2002).

\subsubsection{Propriedades Mecânicas das Fibras}

A grande parte das fibras pertence à categoria de materiais poliméricos, sendo que suas estruturas e comportamento de deformação estabelecem valores de resistência. Considerando esta variação, é possível dividir as fibras em duas categorias principais: as fibras convencionais e as fibras especiais. A primeira categoria representa as fibras que são comumente usadas em produtos têxteis tradicionais, incluindo fibras naturais e fibras sintéticas comuns, como o náilon, poliéster, polipropileno e fibras acrílicas. A segunda categoria representa as fibras que são usadas em materiais com foco na função do produto, como por exemplo, as fibras de aramida, de carbono e a de vidro (EL MOGAHZY, 2009b).

\subsubsection{Ensaio Tênsil de Tração}

O ensaio tênsil de tração mede o comportamento dos materiais têxteis quando uma força de deformação é aplicada ao longo do eixo em termos de tenacidade ou resistência tênsil, percentual de alongamento e elasticidade. Define-se tenacidade para fibras e fios como o estresse específico, ou seja, corresponde ao máximo da razão de carga por densidade linear (título) da fibra ou fio, em uma curva tenacidade-alongamento, que pode suportar antes que quebre. Normalmente, as fibras naturais têm uma tenacidade maior, associada a um menor alongamento, ou vice-versa (REEDY; YANG, 2005).

A resistência à ruptura ou tenacidade é expressa em g/tex ou mN/tex, onde: i) $\mathrm{mN}$ é uma medida de força significando "miliNewton"; ii) tex significa o título da fibra ou fio representando gramas por 1000 metros de fibra ou fio; e iii) $(1 \mathrm{mN} / \mathrm{tex})=(9,81 \mathrm{x} 1 \mathrm{~g} / \mathrm{tex})$. A tenacidade trata-se de um valor intrínseco ao material independente de suas dimensões. Fibras com maior resistência permitirão a produção de fios com boa tenacidade a altas velocidades e taxas de estiragem (SAVILLE, 2007; KASWELL, 1963).

O “Módulo de Young” é a razão da variação da tensão na variação do alongamento dentro do limite elástico do material. A razão é calculada pela tensão, expresso em força por unidade de área de seção transversal, e o alongamento, expresso como uma fração do comprimento original. O engenheiro e o tecnólogo têxtil podem usar essa razão, mas 
devido ao fato dos diagramas de carga-alongamento de têxteis não serem geralmente lineares em sua inteira faixa de uso, o "módulo tensional" de uma fibra não é constante e deve ser usado somente em condições onde é propriamente definido. O Módulo de Young também pode ser relacionado à resistência e rigidez da fibra têxtil (KASWELL, 1963). Assim, quanto maior o módulo de um material, menos ele se estende em função de aplicação de determinada força. Algodão tem módulo menor que linho e juta e, portanto, é mais flexível e macio (REEDY; YANG, 2005).

\subsubsection{Propriedades de absorção das Fibras}

\section{- Recuperação de umidade - Regain}

A quantidade de umidade natural encontrada nos materiais têxteis pode variar conforme o tipo de fibra usada na confecção do produto. A propriedade de absorver a umidade é uma característica dos materiais têxteis (MORTON; HEARLE, 2009a). As variações de umidade encontradas nas fibras estão diretamente relacionadas à umidade do ar no ambiente. A fibra tende a adaptar-se e, como consequência, podem ocorrer alterações no seu peso (SILVEIRA, 2011).

Também a absorção altera as propriedades das fibras, provoca inchaço, o que altera as suas dimensões, e isto, por sua vez, causará mudanças no tamanho, forma, rigidez e permeabilidade de fios e tecidos. Para medir o regain, que é a recuperação percentual de umidade de uma fibra seca, é necessário pesar a amostra de material, realizar a secagem e pesar novamente a amostra seca (SAVILE, 2002).

\subsubsection{Propriedades Químicas das Fibras}

\section{- Resistência alcalina, ácida e agente oxidante.}

As fibras serão expostas a muitos produtos químicos durante o seu processamento e a sua utilização, que podem afetar as suas propriedades. Por um lado, álcalis podem quebrar e danificar fibras de proteína, como a seda e a lã, mas são menos prejudiciais às fibras celulósicas naturais. Em alguns casos, e podem até ser utilizado para melhorar a sua resistência e aparência, como no caso do algodão, no processo de acabamento utilizando hidróxido de sódio, conhecido por mercerização. Álcalis também podem ser usados para alterar as propriedades de algumas fibras sintéticas, como por exemplo, melhorando a finura do poliéster pelo processo de causticação. Os ácidos irão quebrar e danificar fibras celulósicas, enquanto que as fibras proteicas são mais resistentes aos ácidos. Algumas fibras são vulneráveis à oxidação, quer seja por produtos químicos 
durante o processamento ou pelo oxigênio presente no ambiente, particularmente quando combinado com luz solar (FAN; LAU, 2009).

\subsubsection{Propriedades Térmicas das Fibras}

\section{- Condutividade Térmica}

A condutividade térmica é a capacidade de uma fibra conduzir calor. A maioria das fibras apresenta baixa condutividade térmica, tornando-as bons isolantes térmicos (FAN; LAU, 2009).

A condutividade térmica de um tecido depende muito mais do ar preso na sua estrutura do que da condutividade da fibra. Mudanças dimensionais nos tecidos devido ao inchaço reversível pela absorção da umidade são maiores do que aquelas resultantes da expansão térmica reversível (MORTON; HEARLE, 2009b).

De acordo com Saville (2002a), as principais propriedades para o vestuário manter o calor balanceado do corpo durante vários níveis de atividades são: a condutividade térmica das fibras, responsável pelo transporte de calor, a resistência ao vento, à permeabilidade do vapor de umidade e resistência à água, as quais são partes integrantes do conforto térmico de uma roupa. Além disso, El Mogahzi (2009), lista quatro fatores ambientais básicos para determinar o conforto térmico, sendo a temperatura do ar, a umidade relativa, a velocidade do ar e calor radiante.

\section{- Decomposição, amolecimento e derretimento.}

A resposta das fibras ao calor depende principalmente e sua composição química e pode ser divididas em termoplástica, as quais amolecem e derretem acima de certas temperaturas e as fibras não termoplásticas, que tendem a carbonizar e fragilizar-se em altas temperaturas (FAN; LAU, 2009).

O comportamento de queima de algumas fibras têxteis pode ser observado na Tabela 4.6, é determinado pelas temperaturas de transição térmica e parâmetros termodinâmicos. A primeira transição é do estado endurecido ou relativamente frágil para um estado viscoso, chamado de transição vítrea $(\mathrm{Tg})$, quando acontece o amolecimento das fibras. Continuando o aquecimento, chega-se a temperatura de derretimento ( $\mathrm{Tm}) \mathrm{e}$ depois a pirólise (Tp), momento em que a decomposição térmica do material se inicia. A temperatura para se iniciar a chama é maior que a temperatura de pirólise, sendo denominada de temperatura de ignição (Tc). Também uma forma de medição das condições de queima é o Índice de Limite de Oxigênio (LOI) que classifica a 
inflamabilidade dos materiais através do valor necessário de oxigênio para o material manter a chama depois de retirada sua fonte (HORROCKS, 2001).

Tabela 4.6 - Transição Térmica das fibras têxteis mais comuns

\begin{tabular}{cllrrrrr}
\hline Classificação & Fibra & $\begin{array}{c}\text { Tg, }{ }^{\mathbf{0}} \mathbf{C} \\
\text { Amolece }\end{array}$ & $\begin{array}{r}\text { Tm, }{ }^{\mathbf{0}} \mathbf{C} \\
\text { Derrete }\end{array}$ & $\begin{array}{c}\text { Tpp, }{ }^{\mathbf{0}} \mathbf{C} \\
\text { Pirólise }\end{array}$ & $\begin{array}{c}\text { Tc, }{ }^{\mathbf{0}} \mathbf{C} \\
\text { Ignição }\end{array}$ & \multicolumn{1}{c}{ LOI } \\
\hline Natural & Lã & - & - & 245 & 600 & 25 \\
& Algodão & - & - & 350 & 350 & 18,4 \\
Regenerada & Viscose & - & - & 350 & 420 & 18,9 \\
Sintética & Náilon 6 & 50 & 215 & 431 & 450 & $20-21,5$ \\
& Náilon 6.6 & 50 & 265 & 403 & 530 & $20-21,5$ \\
& Poliéster & $80-90$ & 255 & $420-447$ & 480 & $20-21$ \\
& Acrílico & 100 & $>220$ & 290 & $>250$ & 18,2 \\
& Polipropileno & 20 & 165 & 470 & 550 & 18,6 \\
Alto desempenho & Meta-aramida & 275 & 375 & 410 & $>500$ & $29-30$ \\
& Para-aramida & 340 & 560 & $>590$ & $>550$ & 29 \\
\hline
\end{tabular}

Fonte: Adaptado de Horrocks (2001)

\subsubsection{Fibras Naturais}

A fibra é uma entidade elementar e linear, com características longitudinais e transversais, constituídas de elementos químicos primários (MUSSIG; SLOOTMAKER, 2010).

Acredita-se que na busca de elementos para a produção de vestes destinadas ao aquecimento corporal, centenas de fibras foram coletadas e examinadas como potencial matéria-prima. Tal busca incluiu pelo de animais, as partes fibrosas das plantas, desde as mais grosseiras como as urtigas, até as mais finas como a pluma de algodão. Também os filamentos formados por insetos, como a teia de aranha e o fio do casulo do bicho da seda, foram testados para torção e formação de fios (COOK, 2001).

As fibras naturais crescem em múltiplas altitudes geográficas. Várias partes dessas plantas lignocelulósicas como madeiras, haste, folhas, cana, palha, grama e semente são fontes de fibras viáveis, disponíveis não somente para aplicações têxteis, mas também para materiais de construção, alimento animal e humano, químico, cosméticos amigáveis ao meio ambiente e fontes para biopolímeros e energia (KOZLOWSKI; MACKIEWICZTALARCZYK, 2012b).

A variação das propriedades básicas com a finura, flexibilidade, resiliência e formato das fibras naturais, proporcionam uma grande diversidade de fios que satisfazem as solicitações nos dias atuais de resistência e conforto das roupas ofertadas aos consumidores. No contexto atual, as fibras naturais mais importantes são o algodão, a lã, a juta, o linho e a seda. Também o sisal e o rami são bastante utilizados e outras fibras de origem vegetal têm sido exploradas com a paina e o abacaxi (COOK, 2001). 
As fibras naturais de origem vegetal são extraídas das plantas e a celulose é o principal componente desta fibra. As categorias de celulose natural incluem fibras de sementes, fibras de caule, fibras de folhas e até fibras de cascas como de coco. Celulose caracteriza-se por ser um polímero linear de cadeia longa e não é solúvel em água devido ao seu tamanho. Trata-se de um hidrato de carbono composto por 44,4\% de carbono; $6,2 \%$ de hidrogênio e 49,4\% de oxigênio e o diagrama na molécula de celulose, formada por unidades básicas de celobiose pode ser observado na Figura 5. Celobiose $\left(\mathrm{C}_{11} \mathrm{H}_{22} \mathrm{O}_{11}\right)$ é formada por duas unidades de glicose $\left(\mathrm{C}_{6} \mathrm{H}_{12} \mathrm{O}_{6}\right)$ e muitas unidades de celobiose formam a celulose (COOK, 2001).

Figura 5 - Estrutura da molécula de celulose

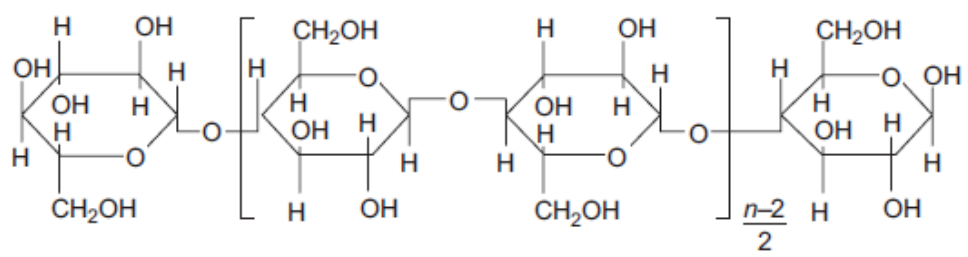

Fonte: Cook (2001)

\subsubsection{Fibras de Sementes}

\section{- Algodão}

A fibra de algodão é retirada das sementes da planta Gossypium. Depois de florescer, uma cápsula alongada é formada, na qual as fibras crescem. Ao completar o ciclo de crescimento as cápsulas se abrem e as fibras emergem. Uma cápsula de algodão aberta é chamada de capulho, a qual pode ser observada na Figura 6. Cada um contém cerca de 30 sementes e cada semente contém de duas mil a sete mil fibras. As condições de crescimento influenciam na cor da fibra, a qual se caracteriza por um fator determinante para o seu preço (DOCHIA et al., 2012).

Figura 6 - (a) Capulho de algodão maduro; (b) Algodão colorido, BRS Rubi.

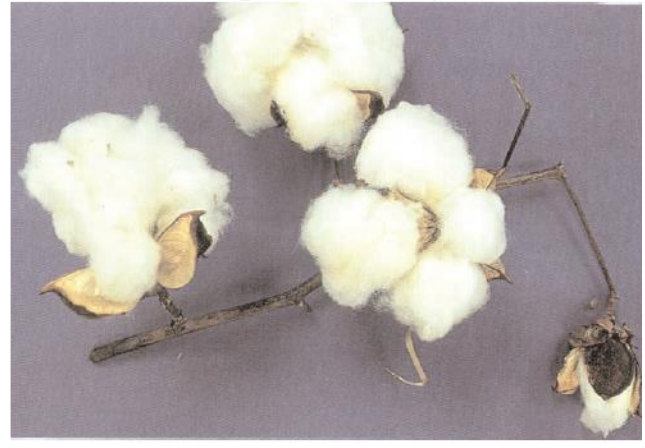

(a)

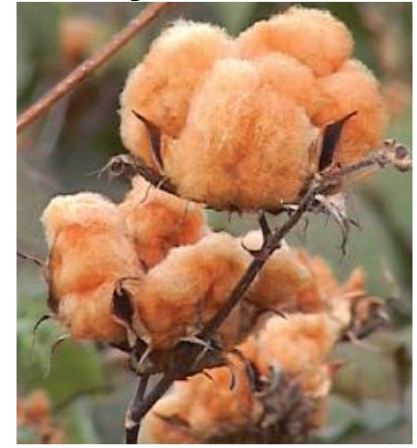

(b)

Fonte: (a) Hargrave (1997); (b) -Empresa Brasileira de Pesquisa Agropecuária - EMBRAPA (2017) 
O gênero Gossypium abrange cinquenta espécies distribuídas nas regiões tropicais e subtropicais no mundo e somente quatro espécies produzem fibras fiáveis (MANSOOR; PATERSON, 2012). As quatro principais espécies são a G. hirsutum com aproximadamente $90 \%$ da produção mundial de algodão. As outras espécies são a $G$. hebaceum (África), a G. arboreum (Ásia e Índia) e a G. barbadense (América) (ZHANG et al., 2014).

O cultivo de algodão para fins comerciais é feito em base anual, sendo necessário clima quente. O período entre a plantação e colheita varia de cinco a sete meses, sendo os principais produtores a China e a Índia (COOK, 2001). De acordo com informações da Food and Agriculture Organization of the United Nation (FAO), em 2016 a produção mundial foi de 65 milhões de toneladas (Gráfico 1).

Gráfico 1 - Produção Mundial de Algodão em 2016.

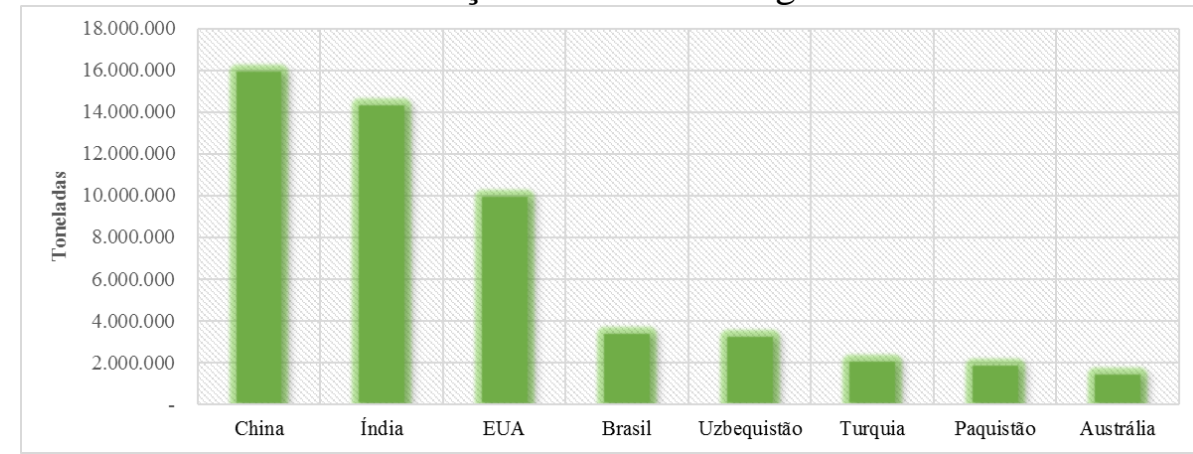

Fonte: Adaptado de Food and Agriculture Organization of the United Nations - FAO, (2018)

\section{- Classificação do Algodão}

Os cuidados com a produção da fibra de algodão se inicia na colheita, a qual se conduzida de forma inadequada compromete a qualidade da fibra e o preço final (JERÔNIMO et al., 2014).

A classificação inicial das fibras de algodão é feita pelo seu comprimento. As fibras de 30 a $40 \mathrm{~mm}$ são classificadas como fibras extralongas, apresentando de alta qualidade. Exemplos são o algodão Egípcio e o Pima. O cultivo destas plantas é difícil e com produção limitada. São fibras mais caras e usadas em tecidos finos e produtos de luxo. As fibras produzidas em maior quantidade, caracterizando-se como padrão, são aquelas com comprimento entre 25 a $33 \mathrm{~mm}$, ultrapassando $90 \%$ da produção mundial de algodão. Trata-se de uma fibra muito utilizada para roupas, mobílias e produtos industriais. Já as fibras curtas menores que $25 \mathrm{~mm}$ tornam o processo para transformação em tecido muito difícil e somente utilizada para produtos de baixo custo (COSTA et al., 2006). 
A cor varia de branco puro até amarelado. Entretanto a classificação normalizada para cores é o branco, ligeiramente creme, creme, avermelhado e amarelado (JERÔNIMO et al., 2014). A forma para determinar as características da fibra de algodão para determinação de sua classificação e valor comercial é com o uso do equipamento HVI (High Volume Instrument). O algodão em pluma tem as seguintes determinações realizadas pelo HVI: Mic $=$ Micronaire em $\mu \mathrm{g} / \mathrm{in}$; $\mathrm{STR}=$ Resistência a ruptura em gf/tex; Len $=$ Comprimento em polegadas, Unf = Índice de Uniformidade, SFI = Índice de fibras curtas em \%; Elg = Alongamento em \%; T = Leaf (folhas); Área = área de impureza em $\%$; CSP = Índice de Fiabilidade; C.G = Grau de cor; $+b=$ grau de amarelecimento e; finalmente, $\mathrm{Rd}=$ Unidade de medida da refletância (quantidade de luz refletida pela fibra, em \%) (COSTA et al., 2006).

\section{- Características físicas, químicas e morfológicas do algodão.}

Como uma representante significativa das fibras de celulose, a fibra de algodão é uma semente de célula viva, a molécula de celulose cresce pela adição de moléculas de glicose em um complexo de enzimas. Estruturalmente a característica importante é a polimerização virgem, com as moléculas preenchendo a estrutura conforme são formados. Trinta moléculas formam um complexo enzimático e se agrupam em fibrilas que são os blocos de construção.

As camadas vão se depositando de forma helicoidal até a maturação da fibra, que ao ser cortada longitudinalmente apresenta um secção oca no centro da fibra em formato de rim (HEARLE, 2009) conforme Figura 7.

Figura 7 - Microscopia da fibra de algodão (a) Secção Transversal (b) vista longitudinal

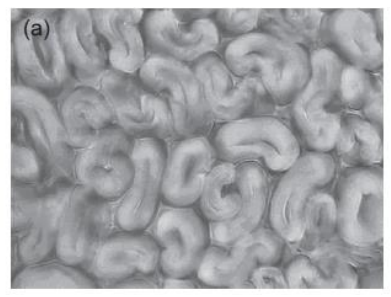

(a)

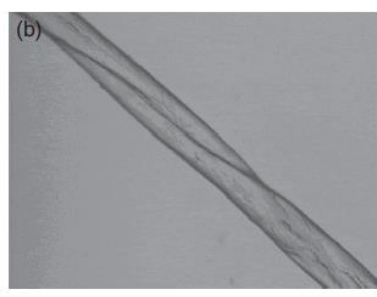

(b)

Fonte: Hearle (2009)

O algodão é um material altamente cristalino, que se queima ou carboniza antes de derreter e quando exposto a água ou vapor ele incha, mas depois de seco, retorna a sua configuração inicial (HARGRAVE, 1997). Na composição química do algodão prevalece a celulose com índices maiores que $90 \%$. As constituintes químicas da fibra de algodão podem ser observadas na Tabela 4.7. 
Tabela 4.7 - Composição Química do algodão

\begin{tabular}{l|rr}
\hline Constituinte & \% (seco) & \multicolumn{1}{c}{ Faixa } \\
\hline Celulose & 94,00 & $88,00-96,00$ \\
Proteína & 1,30 & $1,10-1,90$ \\
Pectinas & 0,90 & $0,70-1,20$ \\
Cinzas & 1,20 & $0,70-1,60$ \\
Cera & 0,60 & $0,40-1,00$ \\
Ácidos orgânicos & 0,80 & $0,50-1,00$ \\
Açúcar total & 0,30 & $0,10-1,00$ \\
Outros compostos orgânicos & 0,90 & $0,50-1,00$ \\
\hline
\end{tabular}

Fonte: Adaptado de COOK (2001) e Maluf; Kolbe (2003)

Dessa forma, as variações nos constituintes químicos da fibra de algodão intensificam as diferenças na maturidade das fibras, variedade do algodão e nas condições ambientais, tais como o tipo de solo, clima e as práticas de cultura (JERÔNIMO et al., 2014).

\subsubsection{Fibras de Caule}

As fibras de caule formam feixes ou cordões que atuam como calhas na camada fibrosa situada sob a casca de plantas dicotiledôneas, que são aquelas que contêm dois cotilédones envolvidos pela semente. Cotilédone é a substância de reserva energética transferida ao desenvolvimento do embrião durante a germinação. Eles ajudam a manter a planta ereta e são fibras construídas de longas células de paredes espessas que se sobrepõem uma à outra, cimentados em conjunto por materiais não celulósicos para formar fios contínuos (COOK, 2001).

As principais plantas para extração de fibras de caule são o linho, rami, juta, kenaf, cânhamo. As fibras estão localizadas no floema, sendo necessário separar as fibras do xilema. Cada planta apresenta uma composição química conforme demonstrado na

\section{Tabela 4.8.}

Tabela 4.8 - Componente Químicos de diferentes materiais de fibra de caule

\begin{tabular}{l|ccccr}
\hline Variedade de Fibra & $\begin{array}{c}\text { Celulose } \\
(\mathbf{\%})\end{array}$ & $\begin{array}{c}\text { Hemi-celulose } \\
(\mathbf{\%})\end{array}$ & $\begin{array}{c}\text { Pectina } \\
(\mathbf{\%})\end{array}$ & $\begin{array}{c}\text { Lignina } \\
(\mathbf{\%})\end{array}$ & $\begin{array}{r}\text { Gordura } \\
\text { cera (\%) }\end{array}$ \\
\hline Linho & $62-71$ & $16-18$ & $1,8-2,0$ & $3,0-4,5$ & 1,5 \\
Cânhamo & $67-75$ & $16-18$ & 0,8 & $3,0-5,0$ & 0,7 \\
Rami & $68-76$ & $13-14$ & $1,9-2,1$ & $0,6-2,0$ & 0,3 \\
Juta & $59-71$ & $12-13$ & $0,2-4,4$ & $11,8-12,9$ & 0,5 \\
Kenaf & - & - & - & $12,0-15,0$ & - \\
\hline
\end{tabular}

Fonte:(COOK, 2001) 


\section{- Linho (Linum usitatissimum)}

A fibra de caule mais popular e mais difundia é o linho, seguido de perto pelo cânhamo, a partir do qual as roupas são feitas. Linho (Linum usitatissimum) é conhecido por ter sido domesticada e cultivada a cerca de 5000 anos atrás. Sua versatilidade para cultivo em climas e tipos de solo proporcionou que a cultura se espalhasse rapidamente e dentro de 2000 anos podia ser encontrada na Síria, Egito, Suíça e Alemanha. As fibras para fiação são obtidas dos feixes de células ao longo do comprimento da haste e que formam um anel ao redor do córtex (MARTIN et al., 2013; MCDONALDS, 2011).

O linho é uma planta com dupla finalidade, fibras e sementes. A principal utilização é da fibra na indústria têxtil, assim como aplicações técnicas em biopolímeros, indústria automotiva ou aeroespacial, isolamento, material de construção. Pode ser aplicado ainda em remédios, cosméticos e produtos de nutrição. As fibras menores são destinadas à fabricação de polpa, filtro de cigarro, embalagens, laminados, revestimentos, painéis de partículas e nãotecidos (KOZLOWSKI; MACKIEWICZ-TALARCZYK, 2012a). Caracterizam-se por ser uma cultura anual de verão que cresce em climas temperados, áreas subtropicais em uma ampla gama de condições do solo e de clima. (KREITSCHITZ; KOVALEV; GORB, 2015) e a sua aparência pode ser verificada na

\section{Figura 8.}

Figura 8 - Linum usitatissimum. (a) caule e (b) plantação comercial.

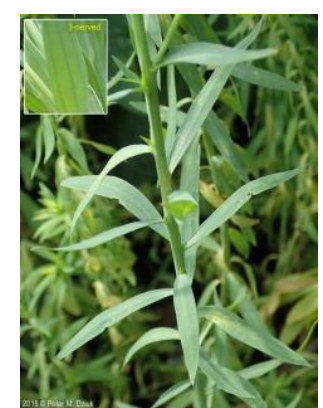

(a)

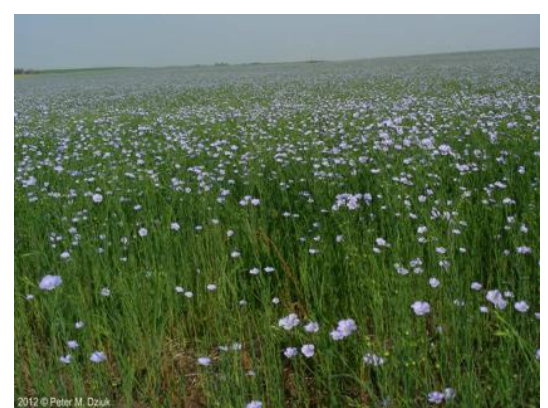

(b)

Fonte: Dziuk; Chayka (2015)

Algumas plantas fibrosas como o salgueiro, provavelmente foram utilizadas por suas excelentes propriedades para confecção de cestas. Os longos e flexíveis ramos jovens podiam ser tecidos e retorcidos na forma desejada. A descoberta da utilização da fibra interna ainda mais flexível pode ter ocorrido quando esses ramos foram deixados ao relento. A fibra exterior apodreceu expondo os feixes com fibras internas mais flexíveis (MCDONALDS, 2011). 
A parte útil do linho para fibras têxteis está na estrutura do talo da planta. As fibras de linho são a parte interna da casca ou das paredes das células do floema dentro do caule. As fibras são tubos ocos, formado principalmente de celulose. Eles crescem como feixes, unidos por carboidratos complexos tais como pectinas, gomas e ceras. Estes feixes de fibras sustentam a planta e, como as fibras são ocas, transportam o material fotosintetizado das folhas por ação de capilaridade (VAISEY-GENSER; MORRIS, 2003).

A origem da fibra é no floema, região da haste a qual provê um importante tecido de condução de alimentos para a planta. A planta do linho contém aproximadamente $25 \%$ de fibra têxtil e $75 \%$ de material não fibroso, muito bem ligado ao caule da planta (SINCLAIR, 2015).

\section{- Produção}

Economicamente dois tipos de linho são conhecidos na agroindústria: o linho para produção de fibras e o linho oleaginoso para produção de semente. A plantação destinada à sementes é mais lucrativa que o linho para têxteis, pois não necessitam de processos complexos e a demanda por sementes de linho no mercado internacional (KOZLOWSKI; MACKIEWICZ-TALARCZYK, 2012a).

Muitas áreas de terra no mundo são destinadas ao plantio do linho tanto para fibras como para sementes. Tais áreas estão distribuídas pelas zonas de clima temperado, sendo que a produção aumenta ou diminui de acordo com as condições do mercado mundial e políticas de subsídio nacional (MARCHENKOV et al., 2003). Além de roupas e estofados, outra aplicação tem sido desenvolvido nas últimas décadas, envolvendo o uso de fibras de linho como reforço para materiais compósitos (GOUDENHOOFT; BOURMAUD; BALEY, 2018).

A área destinada à plantação de linho no mundo é de 221 mil hectares e produção total de 809 mil toneladas no ano de 2016. As plantações estão distribuídas na França, Bélgica, China, Bielorrússia e a Rússia e outras áreas da Europa, sendo que a produção dos cinco maiores produtores mundiais totaliza 772 mil toneladas ano demonstrado no Gráfico 2. (FOOD AND AGRICULTURE ORGANIZATION OF THE UNITED NATIONS - FAO, 2018). 
Gráfico 2 - Produção Mundial de Linho, 2016.

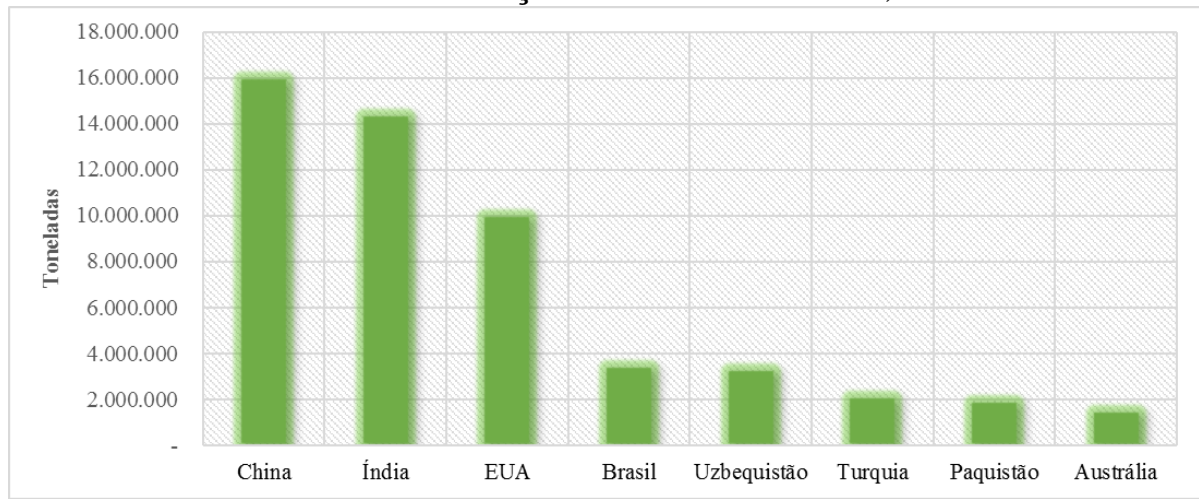

Fonte: Adaptado de Food and Agriculture Organization of the United Nations - FAO, (2018)

No momento existe uma demanda para fibra de linho de alta qualidade para indústria têxtil, adequado para a produção de fios finos e sem os maiores problemas de fiação o que inclui filamentos homogêneos de mesma espessura, força e flexibilidade (KOZLOWSKI; MACKIEWICZ-TALARCZYK, 2012a).

\subsubsection{Fibras de origem animal}

\section{- Lã}

Dentre as fibras naturais, a lã apresenta o melhor comportamento de resistência à queima. É uma fibra que apresenta um LOI de $25 \%$ e sua atividade retardante de chamas pode ser associada com a formação de carbono e que pode ser aumentada quando associado a outros elementos químicos (BOURBIGOT, 2008).

É uma fibra composta de aminoácidos ligados por um peptídeo. As unidades peptídicas são reticuladas por ligações dissulfídicas com grupos reativos tais como amido hidroxilo, imidazol e guanido ligados a eles. Mostra que a estrutura reticulada da queratina não pode ser modificada facilmente como outras fibras de proteínas (KOZLOWSKI; MUZYCZEK, 2012).

A domesticação das ovelhas foi orientada para suprir a necessidade de vestimentas. Era necessário um animal que ao mesmo tempo fornecesse uma pele para ser usada como veste e ao mesmo tempo um animal para fornecer uma fibra macia e confortável. A raça Merino, a mais importante de todas as ovelhas usadas como fonte de lã, praticamente não possuem a camada externa e produz uma lã fina e macia e forma a base da produção na Austrália (COOK, 2001).

A cobertura pilosa da pele de alguns mamíferos, sendo o principal representante a família dos Ovinos, é utilizada historicamente para a obtenção de fibra têxtil. A fibra de lã é de origem proteica e sua principal componente química é a queratina. Independente 
da raça da ovelha, entre elas a Merino, Lincoln ou Sussex, as propriedades químicas e sua morfologia são similares (KUFFNER; POPESCU, 2012; SINCLAIR, 2015).

Entretanto em outras famílias de mamíferos existem animais com potencial para a extração da lã. Alguns deles são: a Família dos camelídeos (alpacas, camelos e vicunha); Família dos Caprinos (mohair, cashmere); Família dos Bovinos (Yak) e os coelhos para obtenção do angorá (NAYAK; PADHYE; FERGUSSON, 2012; TRIDICO, 2009).

De acordo com Tridico (2009), todas as fibras de cabelo de mamíferos são similares em sua estrutura química e comportamento físico, diferenciando-se em pequenos detalhes entre as espécies. Suas características físicas e morfológicas diferem no comprimento e finura e nas formas de suas estruturas.

Comparada com outros mamíferos, a relação da produção de lã de ovelha com a área de pasto é bastante positiva e melhor que de qualquer outro animal produtor de lã. As ovelhas comem a pastagem sem arrancar as raízes, possibilitando que o pasto se regenere rapidamente. A produção aproximada é de um quilo de lã por ano a partir de um hectare de pastagem (KUFFNER; POPESCU, 2012).

\section{- Morfologia da Fibra de Lã.}

Ao se fazer uma análise da fibra de lã, no sentido de seu crescimento será evidenciada duas porções distintas: o folículo e a haste. Quando uma fibra de cabelo começa a se desenvolver, uma série de mudanças ocorre sob a superfície da pele e uma pequena bolsa, chamada folículo se forma. $\mathrm{O}$ folículo é um órgão dinâmico no qual ocorre a divisão, diferenciação e migração das células. Quando a fibra começa a crescer e amadurecer é possível identificar dois tipos de células, a cutícula e o córtex central (TRIDICO, 2009).

Outra maneira de entender a estrutura morfológica de uma fibra de lã é através de um corte transversal da fibra madura. A Figura 9(a) demonstra quatro regiões distintas na fibra de lã. Na região mais externa está uma membrana formando a bainha exterior, que repele água, mas é permeável ao vapor de água, o qual passa pelos poros microscópicos da bainha (A). Em seguida formam-se as cutículas da fibra em uma camada de escamas epiteliais irregulares as quais cobrem a fibra (B). A porção central é o córtex. Ele é construído de forma acumulativa a partir de células longas em forma de fuso que proporcionam a resistência e elasticidade da fibra de lã (C). Por fim, A medula das fibras de lã é por vezes um canal oco, e em fibras mais grossas pode consistir numa rede tubular oca (D) (COOK, 2001). 
Figura 9 - Fibra de lã. (a) Secção longitudinal da fibra. (b) Secção transversal: (A). Bainha exterior ou epicutícula; (B) Camada de escamas; (C) Córtex e (D) Medula.

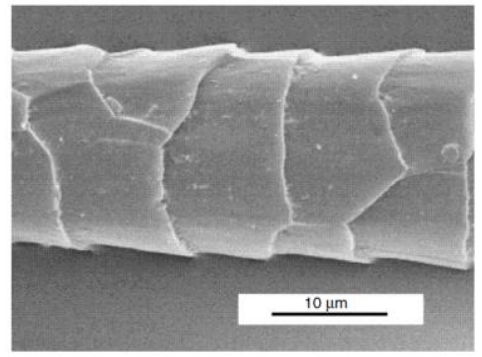

(a)

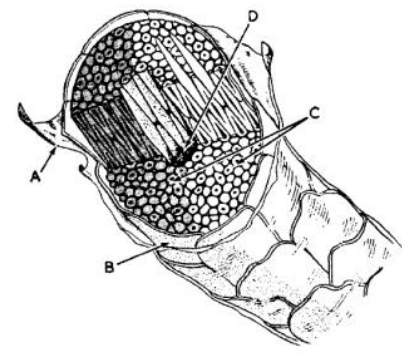

(b)

Fonte: Kuffner; Popescu (2012)

Outra vista é a secção longitudinal ligeiramente elíptica com seu córtex protegido por cutículas em formato de escamas dispostas em sua superfície, observada na Figura 9(b) (NAYAK; PADHYE; FERGUSSON, 2012).

O córtex contém células corticais e o complexo de membrana celular. Em resumo, o córtex é formado de micro fibrilas ou proteínas de queratina e proteínas associadas à queratina que compõem a matriz intermicrofibrilar contendo remanescentes citoplasmáticos e nucleares (MUSSIG; SLOOTMAKER, 2010).

A estrutura das proteínas da lã difere entre as várias regiões da fibra. Algumas das proteínas no micro fibrilas são helicoidais, como uma mola, que confere à lã sua flexibilidade, elasticidade, resiliência e boas propriedades de recuperação de rugas. Também existem outras proteínas, particularmente na matriz que envolve as micro fibrilas, tem uma estrutura mais amorfa permitindo que a lã absorva quantidades relativamente grandes de água (até cerca de 30\% da massa da fibra seca). As proteínas da matriz são também responsáveis pela capacidade da lã de absorver e reter grandes quantidades de corante (SINCLAIR, 2015).

\section{- Características químicas e físicas da fibra de lã.}

A proteína que compõe a fibra de lã é a queratina. As proteínas são formadas pela união de $\alpha$-aminoácidos com peptídeos o qual retém um grupo terminal amino $(\mathrm{NH}+)$ e um terminal de ácido carboxílico (CO-) resultante da eliminação da água. O arranjo químico da fibra de lã é reticulado (crosslinked) de proteínas de queratina, feito a partir de 19 diferentes aminoácidos. O aminoácido mais importante é a cistina, o qual contém enxofre e formas de ligações cruzadas entre cadeias adjacentes através das ligações dissulfeto (TRIDICO, 2009). 
A queratina difere da maioria das outras proteínas devido ao seu alto teor de enxofre de cerca de 3-4\%. Além disso, a composição da lã são proteínas, consistindo nos elementos carbono, hidrogênio, oxigênio e azoto (SINCLAIR, 2015).

Dessa forma a resistência da lã a ação do fogo, pode ser creditada a grande quantidade de nitrogênio contido em sua fibra. O material de lã apresenta dificuldade para ignição, tem uma propagação lenta da chama e uma vez extinta a fonte de fogo ela para de queimar. Em alguns casos, quando a gramatura for maior que $800 \mathrm{~g} / \mathrm{m}^{2}$, a lã é considerada um material não combustível (KOZLOWSKI; MUZYCZEK, 2012).

Por sua vez, o comportamento térmico da lã contribui para torná-la uma fibra segura. Quando a lã é aquecida no ambiente, a perda de água começa em $105^{\circ} \mathrm{C}$. A fibra torna-se fraca e perde a sua suavidade quando aquecida à temperatura de água fervente por longos períodos de tempo (COOK, 2001).

Quando o a temperatura se aproxima dos $200^{\circ} \mathrm{C}$ e até $400^{\circ} \mathrm{C}$ inicia-se a perda de massa com processo endotérmico, no momento em que as cadeias de proteínas se decompõem em produtos mais leves e compostos voláteis como $\mathrm{CO}, \mathrm{NH}_{3}$ e $\mathrm{H}_{2} \mathrm{~S}$. Na segunda fase de queima, já com a temperatura na faixa de $450^{\circ} \mathrm{C}$ a $600^{\circ} \mathrm{C}$, o processo exotérmico se inicia e alguns produtos da pirólise reagem com o oxigênio por meio de várias reações na fase gasosa, levando a produtos a oxidação (KUFFNER; POPESCU, 2012). A lã não continua a queimar quando a chama é removida (COOK, 2001). Também, lã necessita de mais oxigênio para queimar do que está disponível no ar. Ela não derrete, goteja ou cola no corpo do usuário quando queimada (KUFFNER; POPESCU, 2012).

Um processo para aumentar a propriedade de retardar as chamas no tecido feito de fibra de lã é bastante conhecido e designado Zirpro. Trata-se da exaustão de complexos carregados negativamente de zircônio ou titânio sobre as fibras de lã carregadas positivamente em solução ácida em temperatura de $60^{\circ} \mathrm{C}$. O efeito retardante de chamas é atribuído ao aumento da formação de uma de barreira contra calor e chamas. Recentemente no mercado para atender os assentos fabricados com lã, principalmente aqueles usados pelas companhias aéreas estão disponíveis retardantes de chamas com base fosforada sob o nome comercial de Noflan da empresa Firestop Chems. Ltd., um retardante organo fosfórico que pode ser uma alternativa moderna para o Zirpro com o mesmo modo de ação (BOURBIGOT, 2008). 


\subsubsection{Fibras Manufaturadas}

As fibras químicas podem ser divididas em artificiais produzidas a partir da celulose (raiom e raiom viscose) e sintéticas produzidas a partir de produtos petroquímicos (acrílico, o náilon, poliéster, polipropileno, etc.).

É possível encontrar fibras químicas em três formas distintas. O monofilamento (único fio contínuo), multifilamento (um ou mais monofilamentos unidos por torção) ou a fibra cortada para mistura com outras fibras no processo de fiação.

São fibras produzidas por extrusão de uma solução de polímero ou com o polímero fundido, fazendo passar o material líquido através da fieira, num ambiente que provoca a solidificação ou coagulação das fibras.

\subsubsection{Conceitos básicos sobre polímeros}

A principal matéria prima da indústria petroquímica é a nafta, que gera os petroquímicos básicos como as olefinas e os aromáticos. Após o processo de reforma catalítica é obtidas a gasolina com elevado índice de octanagem e os produtos rico em hidrocarbonetos aromáticos nobres (benzeno, tolueno e xileno) usados como matéria prima em indústria químicas e petroquímica (GOMES, 2007).

Com o desenvolvimento do plástico na metade do século XX, começa o entendimento sobre a verdadeira natureza de um polímero, um material feito pelo homem que começa a permear muitas atividades da vida cotidiana (EBEWELE, 2000). Conforme Depaoli (2008) polímeros são macromoléculas que entram na composição de plásticos e borrachas. Acrescente-se que os materiais poliméricos contribuem para a qualidade de vida, servindo de vestuário, embalagem, peças de automóveis ou equipamentos de comunicação.

Os estudos orgânicos e físicos levaram ao primeiro entendimento do conceito estrutural de polímero como uma longa cadeia ou uma rede de moléculas ligadas de forma covalente (EBEWELE, 2000).

A palavra polímero origina-se do grego poli (muitos) mais meros (iguais), significa que são macromoléculas formadas pela repetição de muitas unidades químicas iguais. Usa-se o nome do monômero que foi utilizado na síntese e não o nome químico da unidade repetida (DEPAOLI, 2008).

Os polímeros são classificados também por sua origem: natural, sintético ou seminatural, que seria um polímero natural modificado sinteticamente. A classificação mais usual baseia-se na propriedade física, no módulo de elasticidade e grau de 
alongamento. De acordo com este critério, os polímeros podem ser elastômeros, plásticos ou fibras (BEYLER; HIRSCHLER, 2002).

Elastômeros ou borrachas são caracterizados pela larga escala de "extensibilidade", que torna sua deformidade completamente reversível à temperatura ambiente. Os plásticos revertem sua deformidade parcialmente. Também podem ser classificados por sua composição química, a qual indica suas reações incluindo seu mecanismo de decomposição térmica (BEYLER; HIRSCHLER, 2002).

\subsubsection{Decomposição térmica de um polímero}

Os materiais poliméricos sólidos sofrem transformação química e física quando o calor é aplicado e que geralmente tais mudanças não são desejáveis e acorrem nas propriedades do material (BEYLER; HIRSCHLER, 2002).

Neste ponto, é necessário fazer a distinção entre decomposição térmica e degradação térmica, e de acordo com a descrição Depaoli (2008):

Decomposição Térmica: Um processo de grande mudança química causada pelo calor.

Degradação Térmica: Alteração na qualidade de interesse de um polímero, (flexibilidade, resistência elétrica, aspecto visual, resistência mecânica, dureza), causada por qualquer reação química de diversos tipos que podem ser intra ou intermolecular. Trata-se de um processo pelo qual a ação do calor ou alta temperatura em um material ou produto provoca a perda das propriedades físicas, mecânicas ou elétricas.

No estudo do fogo, a mudança importante é a ocorrida durante a decomposição térmica, pela qual a decomposição química de um material sólido gera vapor de combustíveis gasosos, podendo queimar abaixo do material sólido. Para o processo ser autossuficiente, é necessário que os gases de combustão retroalimentem o calor para o material continuar a produção de vapor de combustíveis gasosos voláteis. Neste caso, o calor transferido para o polímero causa a geração de voláteis inflamáveis, que reage com o oxigênio no ar abaixo do polímero. Como consequência, gera calor e uma parte deste calor é transferida de volta para o polímero continuar o processo de queima (BEYLER; HIRSCHLER, 2002). 


\subsubsection{Fibras de alto desempenho}

\section{- Aramidas}

Muitas fibras manufaturadas são modificadas para atender usos específicos com melhoria em sua tenacidade, finura, perfil de superfície, acabamento e outras combinações (BYRNE, 2000). As aramidas mais conhecidas são a poli (p-fenileno tereftalamida), PPPT e a poli (m-fenileno isoftalamida) PMPI (GARCÍA et al., 2010).

As poliamidas aromáticas, chamadas de aramidas são consideradas materiais de alto desempenho por suas excelentes características em resistência mecânica e térmica. Essas propriedades são resultados de sua estrutura aromática com pelo menos $85 \%$ dos grupos aminas ligada diretamente a dois anéis aromáticos ilustrados na Figura 10 (GARCÍA et al., 2010) a qual apresenta uma estrutura molecular aromática regular conferindo as moléculas uma grande isotropia longitudinal (ALFIERI, 2011).

Figura 10 - Aramida (a) PMPI - poly (m-phenylene isophthalamide), nomes comerciais Nomex $^{\circledR}$ (DuPont), Phenylon ${ }^{\circledR}$ (Rússia), Teijinconex ${ }^{\circledR}$ (Teijin Aramid), (b) (p-phenylene terephthalamide), PPPT, nomes comerciais $\operatorname{Kevlar}^{\circledR}$ (DuPont), Twaron ${ }^{\circledR}$ (Teijin Aramid).

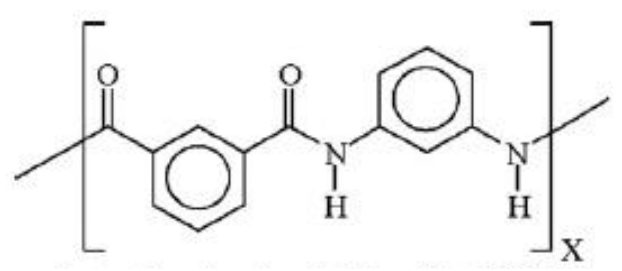

(a)

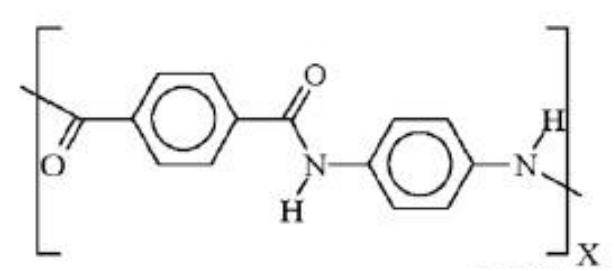

(b)

Fonte: García et al.( 2010)

As aramidas são uma classe particular de poliamidas em que todos os grupos amida são separados por grupos n-Fenil, ou seja, os grupos amida ligam aos anéis fenil opostos uns aos outros, nos carbonos 1 e 4 .

A para-aramida é geralmente utilizada para aplicações que exigem alta resistência e alto módulo, tais como materiais compósitos para aplicações aeroespaciais ou como reforçadores de concreto (CANAL; GINEBRA, 2011). As propriedades da fibra de aramida ou poliamida aromática são determinadas pela microestrutura química e física.

As marcas comerciais de fibras de para-aramida são o Kevlar ${ }^{\circledR}$ da Dupont ${ }^{\mathrm{TM}}$ e o Twaron ${ }^{\circledR}$ da $A \mathrm{kzo}^{\mathrm{TM}}$. A série de Kevlar® é projetada com orientação progressivamente mais elevada das moléculas de polímeros e cristalinidade. As meta-aramidas tem com marcas comerciais o Nomex ${ }^{\circledR}$ da Dupont ${ }^{\mathrm{TM}}$, Teijinconex ${ }^{\circledR}$ da Teijin ${ }^{\mathrm{TM}}$, Newstar ${ }^{\circledR}$ da Yantai Tayho $^{\text {TM }}$, X-Fiber ${ }^{\circledR}$ da SRO ${ }^{\mathrm{TM}}$ e o Kermel ${ }^{\circledR}$ da Kermel ${ }^{\mathrm{TM}}$ (MAO, 2014). 
A estrutura aromática com a substituição de toda ligação para pelos grupos metafenil, ou seja, os grupos amida estão ligados ao anel fenil nas posições 1 e 3. Cria uma haste rígida como macromoléculas com uma elevada energia coesiva e alta tendência de cristalização devido ao efeito favorável de ligações intramoleculares de hidrogênio (GARCÍA et al., 2010). A transformação por fiação úmida em fibras sintéticas resistentes a chamas, cortes e com alta resistência à tração, formando as fibras por coagulação em meio aquoso ou de ácido sulfúrico diluído e não há estiragem no processo (ALFIERI, 2011).

Para aplicações que exigem alta resistência e módulo a recomendação é a paraaramida, utilizada em coletes a prova de balas, reforço de pneus, mangueiras, cordas e compósitos avançados (BYRNE, 2000). Poliamida aromática com orientação meta no anel fenile, tem menor estrutura linear e redução na energia coesiva e tendência à cristalização e continua sendo um polímero de alto rendimento com alta resistência térmica e mecânica (GARCÍA et al., 2010).

\section{- PBO}

PBO (Polyphenylenebenzobisoxazole) é classificada como fibra de alto desempenho e está disponível com o nome comercial de Zylon® fabricado pela Toyobo $^{\mathrm{TM}}$. Possuem propriedades térmicas superiores as demais fibras de alto desempenho e duas vezes mais forte que as para-aramidas convencionais que pode ser observado na Tabela 4.9. Sua aplicação pode atender as áreas de vestes balísticas e capacetes (GONG; CHEN, 2000) e também materiais compósitos para isolamento térmico (GAO et al., 2010).

Tabela 4.9 - Comparação das propriedades mecânicas e térmicas entre fibras de paraaramidas (Twaron ${ }^{\circledR}$-1001) e PBO (Zylon ${ }^{\circledR}$ - HM)

\begin{tabular}{l|cc}
\hline Propriedades & Aramida & PBO \\
\hline Fornecedor & $\begin{array}{c}\text { Teijin Co. } \\
\text { Japão }\end{array}$ & $\begin{array}{c}\text { Toyobo Co. } \\
\text { Japão }\end{array}$ \\
Nome comercial & Twaron ${ }^{\circledR}-1001$ & Zylon $®-$ HM \\
Resistência à tração $(\mathrm{GPa})$ & 3,0 & 5,8 \\
Módulo de tensão $(\mathrm{GPa})$ & 125 & 280 \\
Alongamento na quebra $(\%)$ & 2,3 & 2,5 \\
Densidade $\left(\mathrm{g} / \mathrm{m}^{-3}\right)$ & 1,44 & 1,56 \\
LOI $($ Limiting Oxygen Index $) \%$ & 29 & 68 \\
Temperatura de Pirólise $\left({ }^{\circ} \mathrm{C}\right)$ & 550 & 675 \\
\hline
\end{tabular}

Fonte: Adaptado de Gao et al.(2010)

O PBO é um polímero lítico de haste rígida, característica lhe confere uma cristalinidade líquida em uma solução em função da concentração do polímero. $\mathrm{O}$ 
polímero é sintetizado usando 2,5-diamino-1,3-benzenediol (DABDO) e ácido tereftálico (TA) ou derivados. A fiação é realizada sem precipitação polimérica e re-dissolução. Por seu comportamento líquido cristalino, as moléculas de polímero alcançam orientação durante o fluxo na fieira com maior desenvolvimento de orientação nas lacunas de ar. $\mathrm{O}$ polímero com baixa viscosidade é coagulado com água em temperatura ambiente. A velocidade de coagulação pode ser alterada mudando a temperatura do banho ou o meio de coagulação. As condições de coagulação podem afetar a estrutura da fibra. Continuando o processo, a fibra coagulada é lavada, seca e temperada sob pressão para fortalecer a orientação molecular e alto valor de módulo (CHAE; KUMAR, 2006).

As fibras de alto desempenho têm propriedades físico-químicas superiores em força, módulo, resistência às cortes e altas temperaturas, porém as resistências à flexão, ao cisalhamento e módulo de cisalhamento são relativamente baixas. Tais características podem limitar o uso da fibra em algumas aplicações (CAI et al., 2014). Duas fraquezas do PBO foram detectadas como a forte sensibilidade a luz e a umidade que podem afetar suas propriedades. Um exemplo é o uso de camadas externas protetoras em cordas para barcos a vela feitas de fibras de PBO (DAVIES; BUNSELL; CHAILLEUX, 2010).

\section{- Texteis Técnicos.}

Os têxteis técnicos foram definidos pelo Instituto Têxtil de Manchester em sua publicação Textiles and Fashion: Materials, Design and Technology, como materiais têxteis e produtos fabricados principalmente por suas propriedades técnicas e de desempenho, ao invés de suas características estéticas ou decorativas. Em outras palavras, esses têxteis são utilizados principalmente em função de seu desempenho ou propriedades funcionais, e não pela sua aparência estética como ocorre muitas vezes com os têxteis convencionais (MADRZYKOWSKI; STROUP, 2008).

Têxteis técnicos incluem aqueles destinados a aplicações automotivas, têxteis médicos (implantes), geotêxteis (reforço de taludes), agro têxteis (tecidos para proteção de cultivos) e vestuário de proteção. Não apenas uma grande variedade de matérias primas, mas também muitos processos comuns na fabricação de têxteis convencionais, como tecelagem, malharia, nãotecidos, também são empregados na fabricação de têxteis técnicos (HARROCKS; ANAND, 2000).

Uma grande parte das fibras têxteis utilizadas no mundo industrializado é direcionada para têxteis técnicos, com ênfase em equipamentos de segurança e roupas de proteção. Uma das mais importantes propriedades para este tipo de roupa é a sua 
resistência a pequenos focos de fogo, mas também combinada com a facilidade de limpeza para que a roupa chegue ao final da vida útil ainda mantendo suas características especiais (HALL, 2000).

\subsection{INFLAMABILIDADE}

\subsubsection{Teoria do fogo}

Na definição de Drysdale (2011), o fogo é um processo que pode tomar várias formas e todas envolvem reações químicas entre um combustível e o oxigênio presentes no ar e que gera calor e luz.

A representação mais simples e fundamental da inflamabilidade é o triângulo do fogo (Figura 11a) indicando três componentes: o combustível, o comburente ou agente oxidante e o calor. Tais elementos são necessários para iniciar o fogo (MADRZYKOWSKI; STROUP, 2008).

O combustível é a substância que queima ou ainda o material que alimenta o fogo e compreende uma vasta gama de materiais que podem ser sólidos (papel, madeira, tecidos), líquidos (gasolina, óleo diesel, querosene) ou gasosos (gás natural, metano, butano) (DRYSDALE, 2011).

Os materiais orgânicos, como madeira, itens de mobília, vazamento de gás, caracterizam-se como combustíveis em um incêndio. A reação é rápida, geralmente levando poucos centésimos de segundo. A velocidade da queima e, portanto a intensidade do fogo é geralmente orientada pela taxa na qual o vapor do combustível e ar entram nas chamas, onde as temperaturas são altas o suficiente para iniciar sua reação (DUBOIS et al., 1986).

Comburente é o elemento ativador do fogo, isto é, reage com o combustível, sendo o oxigênio o principal comburente. Por fim, o calor é o elemento necessário para iniciar a reação química entre o combustível e o comburente (DRYSDALE, 2011).

Entretanto, o triângulo não pode descrever todas as condições para a chama, pois não inclui a reação química em cadeia e a reação das moléculas nos gases da chama. Atualmente, o modelo foi ligeiramente atualizado para o tetraedro do fogo (Figura 11b) incluindo um a reação em cadeia, a qual confere as condições para a manutenção da chama. Essas condições incluem a disponibilidade de combustível gasoso e vapores de combustível, os quais só podem ser gerados se houver calor suficiente de fontes externas ou calor retroativo da própria chama do material queimado (MADRZYKOWSKI; STROUP, 2008). 
Figura 11 - (a) Triângulo do Fogo, (b) Tetraedro do Fogo

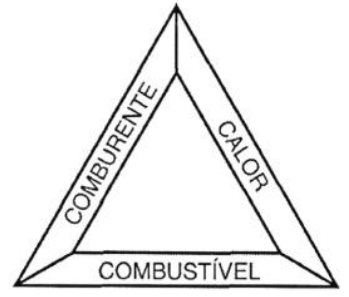

(a)

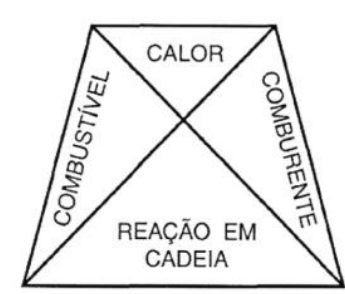

(b)

Fonte: Souza (2012)

Ainda de acordo com Dubois et al. (1986) o vapor de combustível é produzido quando o calor irradiado das chamas volta para a superfície do combustível. O vapor quente sobe, mistura-se com o ar que entra na base das chamas e o alimenta. Esta expansão flutuante cria turbulência, a qual causa maior entrada de ar. Uma fração do calor produzido pela combustão aparece como energia radiante, onde algumas são absorvidas pela camada inferior de combustível e então a evolução dos vapores de combustível continua.

Se o combustível for um líquido volátil, é necessária pouca energia para vaporizálo. Entretanto os combustíveis da maioria dos incêndios são poliméricos, materiais sólidos e geralmente podem ser decompostos (pirolisados) e produzir vapores inflamáveis (DUBOIS et al., 1986).

\subsubsection{Inflamabilidade dos materiais e seus elementos.}

\subsubsection{Ignição}

Processo pelo qual uma reação rápida e exotérmica é iniciada e em seguida se propaga. Requer que a energia suficiente seja suprida de uma forma adequada, como uma faísca elétrica, para iniciar o processo de combustão. Causa mudança no material, produzindo temperatura maior que a do ambiente (DRYSDALE, 2011).

Quando um material é exposto a um fluxo externo e constante de calor (radioativo, convectivo ou uma combinação), a temperatura na superfície começa a subir. A temperatura interna do sólido também aumenta com o tempo, mas em uma taxa mais lenta. Desde que o fluxo de calor dentro do material seja suficientemente alto, a temperatura de superfície eventualmente alcança um nível no qual a pirólise começa (JANSSENS, 2005).

\subsubsection{Propagação superficial da chama.}

Outro importante parâmetro para determinar o risco de inflamabilidade de um material é a sua propensão a suportar a propagação das chamas, sendo que o avanço de 
uma chama induzida por um fluxo de ar natural pode ajudar na propagação ou impedi-la (MADRZYKOWSKI; STROUP, 2008) .

Quando o fluxo de ar no ambiente estiver no mesmo sentido de propagação das chamas, as chamas se espalharão neste sentido e de forma rápida. Quando houver um fluxo de ar no ambiente contrário à propagação das chamas, desacelerará o avanço do fogo (JANSSENS, 2005).

$\mathrm{O}$ risco de inflamabilidade de um material pode ser estimado sabendo-se a velocidade de propagação da chama em sua superfície, sendo mais preciso no ensaio com a ventilação em direção oposta à chama (MADRZYKOWSKI; STROUP, 2008).

\subsubsection{Taxa de liberação de calor.}

Outra variável a ser considerada no estudo de risco de incêndios (JANSSENS, 2005) e usada com frequência para caracterizar os riscos de inflamabilidade de um material específico, é a taxa de liberação de calor. Expressa a energia química liberada durante a queima de um material por unidade de área de superfície exposta $\left(\mathrm{kW} / \mathrm{m}^{2}\right)$. Sob condições controladas para testes de laboratório, uma taxa de liberação de calor inferior à faixa de 50 a $100 \mathrm{~kW} / \mathrm{m}^{2}$ geralmente indica um baixo risco de inflamabilidade (MADRZYKOWSKI; STROUP, 2008) .

\subsubsection{Produtos de combustão.}

O fogo gera materiais particulados, os quais reduzem a intensidade de luz transmitida através da fumaça. (JANSSENS, 2005) e também se caracteriza como o maior risco para as pessoas durante um incêndio (DRYSDALE, 2011). A distância para visualização dos sinais de saída de emergência através da camada de fumaça é diretamente relacionada com a concentração dos particulados na fumaça.

Neste sentido, a geração da fumaça e de outros produtos de combustão dependem do cenário do incêndio, como o tipo e a configuração do material queimado, combustão com chamas ou sem, nível do fluxo de calor externo (MADRZYKOWSKI; STROUP, 2008).

Uma situação agravante é que durante os incêndios, podem-se gerar produtos tóxicos de combustão, principalmente na forma gasosa, sendo dois tipos de gases tóxicos. Os gases tóxicos na forma de monóxido de carbono (CO) e ácido cianídrico (HCN) e os gases irritantes, ácido clorídrico (HCl) e ácido bromídrico (HBr) (JANSSENS, 2005).

Os gases tóxicos são absorvidos na corrente sanguínea e reduzem a condução de oxigênio, que pode levar a perda de consciência e à morte. Os gases irritantes causam 
desconforto respiratório, contribuem para a incapacitação e letalidade durante a exposição à gases do fogo. Inflamação do trato respiratório pode resultar em morte depois de dias e até semanas do evento com fogo. Gases ácidos também causam corrosão em aparelhos eletrônicos e computadores (JANSSENS, 2005).

\subsubsection{Transferência de calor.}

De acordo com Rockett e Milke (2008), o calor ou energia térmica são transferidos para outro objeto por três mecanismos diferentes: por radiação, por convecção e por condução. Também para Drysdale (2011), é provável que todos os três contribuam em caso de incêndio, mas geralmente é encontrado um que predomina em um estágio ou local.

A energia térmica contida em um objeto e sua temperatura são grandezas que se relacionam de forma direta, pois ao aplicar uma caloria em um grama de água à $0{ }^{\circ} \mathrm{C}$, sua temperatura irá aumentar um grau Celsius (ROCKETT; MILKE, 2002).

\subsubsection{Transferência de calor por condução.}

O fenômeno de condução de calor é observado quando um objeto quente é colocado em contato físico com um objeto frio: o objeto quente esfria e o objeto frio esquenta (ROCKETT; MILKE, 2002).

Além disso, a condução determina a taxa do fluxo de calor dentro e através dos sólidos. Torna-se uma característica importante em problemas relativos à ignição e propagação de chamas em combustíveis sólidos e também a resistência ao fogo, quando for necessário conhecer a taxa de transferência de calor entre compartimentos ou no interior de elementos de uma estrutura (DRYSDALE, 2011).

O processo foi estudado por Newton, mas, foi quantificado pela primeira vez por Fourier (Equação 1) em 1812. Em sua equação, Fourier estabelece que a quantidade de calor transferida por unidade de tempo por uma área específica, é proporcional ao gradiente de área e temperatura. O fluxo de calor vai do material mais quente para o material mais frio (ROCKETT; MILKE, 2002).

$$
q_{c d^{\prime \prime}=k \cdot \frac{T_{1}-T_{2}}{L} \quad \text { (Equação 1) }} \begin{aligned}
& \text { Onde: } \\
& \mathrm{q} c d "=\text { Calor transferido } \\
& \mathrm{K}=\text { Condutividade térmica em W/m.K } \\
& \\
& \mathrm{T}_{1}=\text { Temperatura da face } 1 \text { do sólido em K } \\
& \mathrm{T}_{2}=\text { Temperatura da face } 2 \text { do sólido em } \mathrm{K}
\end{aligned}
$$




\subsubsection{Transferência de calor por convecção.}

A transferência de calor por convecção ocorre por uma combinação dos efeitos de condução e o movimento do meio de transmissão, que pode ser líquido ou gasoso (ATREYA, 2002).

Na abordagem de Drysdale (2011), a transferência está associada com a troca de calor entre um gás ou líquido com um sólido (Equação 2). Envolve o movimento do meio fluído. O fenômeno ocorre em todos os estágios do fogo, mas particularmente no começo, quando os níveis de radiação térmica estão baixos.

Também a convecção realiza um papel importante em um evento com fogo, transportando uma grande quantidade de energia química liberada durante a queima para o ambiente através do movimento dos gases quentes que ficam mais leve e sobem. $\mathrm{O}$ ar do ambiente, rico em oxigênio toma o seu lugar e alimenta as chamas (ATREYA, 2002).

$$
\begin{array}{cl} 
& \text { Onde: } \\
& q_{c v^{\prime \prime}}=\text { Calor transferido } \\
& h=\text { Coeficiente de convecção em W/m² } / \mathrm{K} \\
& T_{\text {sup }}=\text { Temperatura da superfície em K } \\
& T \infty=\text { Temperatura do meio em K }
\end{array}
$$

\subsubsection{Transferência de calor por radiação.}

A transferência térmica por radiação não requer a intervenção do meio para ocorrer. É a transferência de energia por ondas eletromagnéticas, sendo a luz visível o exemplo mais conhecido (DRYSDALE, 2011).

Radiação térmica em incêndios envolve a troca de energia entre superfícies (Equação 3) e também a emissão e absorção por vários gases e partículas de fuligem. Dentre estes gases estão os vapores de água e dióxido de carbono, que são absorventes e emitentes dentro do espectro de radiação térmica (TIEN; LEE; STRETTON, 2002).

Drysdale (2011) também estabelece que a radiação em todo o espectro eletromagnético pode ser absorvida, transmitida ou refletida em uma superfície.

$$
\begin{aligned}
& \text { Onde: } \\
& q_{r d^{\prime \prime}=\varepsilon \sigma T_{\text {sup }}^{4} \quad(\text { Equação 3) }} \begin{array}{l}
q_{r d^{\prime \prime}}=\text { Calor transferido, } \\
\varepsilon=\text { Emissividade, }
\end{array} \\
& \sigma=\text { Constante de Steffan-Boltzmann } \mathrm{W} / \mathrm{m}^{2} . \mathrm{K}^{4} \\
& T=\text { Temperatura da superfície em K }
\end{aligned}
$$

\subsubsection{Fogo em espaço confinado}

Quando se trata da abordagem de segurança, os incêndios em locais fechados são considerados os mais importantes. Áreas fechadas ou compartimentos em edifícios, navios e aviões quando se incendeiam, mantêm preso o calor e os produtos de combustão, 
aumentando a severidade do incêndio, tanto física como o impacto daquilo que está exposto (DUBOIS et al., 1986).

Também os eventos com fogo em compartimentos são discutidos em termo de fases. A Figura 12 ilustra o crescimento ou fase inicial, flashover, pleno desenvolvimento ou queima livre e o declínio ou queima lenta. Os eventos de flashover e postflashover ocorrem durante as fases (WALTON; THOMAS, 2002).

Figura 12 -Evolução do fogo em uma sala na ausência de controle de fogo.

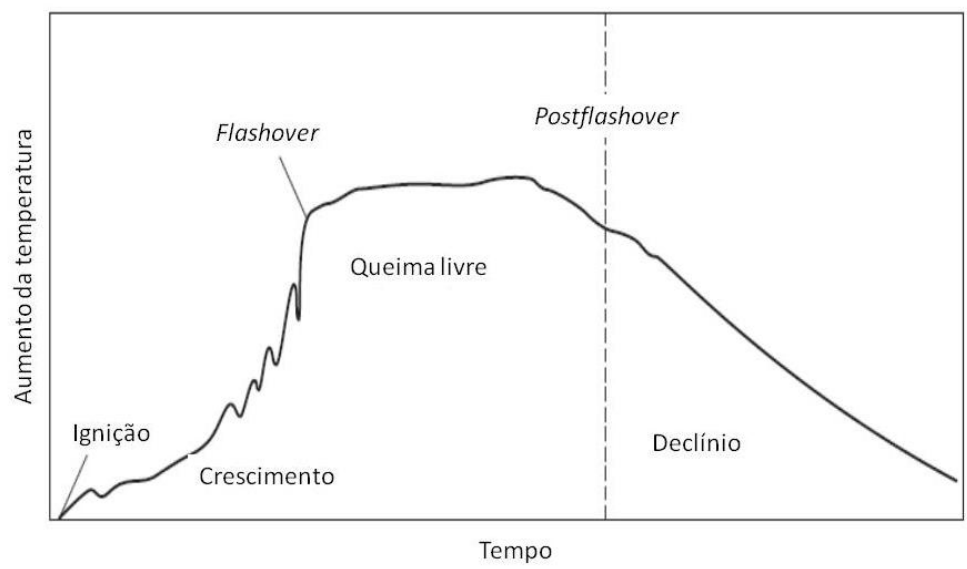

Fonte: Adaptado de Walton; Thomas (2002)

As fases do incêndio em local confinado são descritas por Janssens (2005) e Walton e Thomas (2002) conforme segue:

Ignição: Período no qual o fogo se inicia.

Crescimento ou fase inicial: Seguindo a ignição, o fogo cresce e se mantém em função do combustível e a um tamanho limitado por algum tempo e somente uma pequena área é envolvida. $\mathrm{O}$ fogo pode ser descrito em termos de sua taxa de energia e a geração de produtos de combustão. Se houver combustível e oxigênio suficiente, o fogo irá continuar crescendo, causando o aumento da temperatura no compartimento. À medida que o fogo aumenta, uma camada de fumaça quente se acumula a temperatura aumenta gradativamente.

Flashover: É definido como a transição do estágio de crescimento do fogo para o desenvolvimento total, no qual todos os itens combustíveis no compartimento são envolvidos pelo fogo. O fluxo de calor da chama e da camada de fumaça quente na parte de baixo do compartimento aumenta o suficiente para queimar o material combustível comum. A partir deste ponto, uma rápida transição ocorre para o total desenvolvimento do fogo. Esta transição geralmente leva apenas um minuto. As temperaturas citadas na literatura variam de 300 a $650 \circ \mathrm{C}$ ou 500 a $600{ }^{\circ} \mathrm{C}$. Quando 
ocorre não é possível sobreviver no compartimento, pois a temperatura da camada de fumaça chega aos $600^{\circ} \mathrm{C}$ e um fluxo de calor de $20 \mathrm{~kW} / \mathrm{m}^{2}$.

Pleno desenvolvimento ou queima livre: Leva ao pleno desenvolvimento do fogo no qual todo combustível exposto no compartimento é consumido. A temperatura nesta fase fica entre $800-1000^{\circ} \mathrm{C}$ e fluxo térmico de $75-150 \mathrm{~kW} / \mathrm{m}^{2}$.

Postflashover: Uma vez atingido o estágio de postflashover, a estrutura do edifício fica comprometida. Sem intervenção, o fogo irá consumir todo o combustível do compartimento.

Declínio ou queima lenta: Ocorre quando o combustível for totalmente consumido e a taxa de liberação de calor declina.

Um evento mínimo pode ser fatal. Geralmente começa pequeno, como por exemplo, um cigarro que cai em uma cesta de papel ou a faísca de uma conexão elétrica. Uma vez espalhada, envolve uma grande fonte de combustível, como por exemplo, um item da mobília. Como o fogo vai exaurir rapidamente o oxigênio disponível em uma sala normal, o ar para continuar a queima será alimentado através de passagem por uma porta ou janela. Os produtos de combustão quentes surgem do fogo, quando entra o ar adicional, forma uma camada de fumaça quente e distinta logo abaixo do teto, a qual depende do ar para continuar queimando. Quando a camada quente abaixa para uma porta ou janela aberta, a fumaça começará a sair da sala e espalhar pelo prédio (DUBOIS et al., 1986).

\subsubsection{Fatores de influência da inflamabilidade de têxteis}

A resposta das fibras ao calor depende principalmente e sua composição química e pode ser divididas em termoplástica, as quais amolecem e derretem acima de certas temperaturas que depende da fibra e as fibras não termoplásticas, que tendem a carbonizar e fragilizar-se em altas temperaturas (SINCLAIR, 2015).

Todas as fibras são afetadas de uma forma ou outra quando são aquecidas. Cada fibra reage de acordo com a sua composição química. A lã começa a se decompor sem derreter, outras como o poliéster ou acetato amolecem e derretem antes de se decomporem. São informações importantes para estabelecer os métodos de lavanderia e passadoria. Na presença do ar muitas fibras podem queimar causando vários acidentes todos os anos, tornando os estudos para aumentar a inflamabilidade dos tecidos muito importante (COOK, 2001).

A tendência de um material de se acender e queimar com uma chama criando uma situação de risco de incêndio é explicada por Lewin (1985) e Sinclair (2015) como 
inflamabilidade, ressaltando que em materiais têxteis representa a facilidade com que o tecido é capaz de ser inflamado e como efetivamente ele queima.

Existem também, mercados específicos como uniformes profissional e roupas dos bombeiros, cortinas, carpetes e estofados de ambientes institucionais, comerciais e de transporte, principalmente os regulamentados como de transporte aéreo que geram demanda para têxteis com retardantes de chamas (WEIL; LEVCHIK, 2009).

Além disso, a combustibilidade do tecido está relacionada com a taxa em que a chama é capaz de se propagar. Já a ignição é descrita como um fenômeno mais complexo, que envolve a transferência de calor. As reações exotérmicas são acionadas quando a temperatura de ignição do tecido é atingida. $\mathrm{O}$ alto risco de incêndio atribuído aos tecidos é consequência de sua superfície de grande área e a facilidade de acesso ao oxigênio do ambiente (BOURBIGOT, 2008).

Tanto a forma de construção (tecido plano, malharia e nãotecido) quanto à natureza química de suas fibras, influenciam muito na variação das características de inflamabilidade dos tecidos. Tais características oscilam de muito inflamável no caso de fibras celulósicas e fibras sintéticas comuns, até fibras inerentemente retardantes de chamas (WEIL; LEVCHIK, 2009).

\subsection{LIMITING OXYGEN INDEX (LOI)}

A resposta de uma fibra ao calor depende da sua composição química, uma vez que as manufaturadas sintéticas amolecem e depois derretem e as fibras não termoplásticas tendem a carbonização, tornando-se frágil quando expostas a altas temperaturas (SINCLAIR, 2015).

Uma das medidas de inflamabilidade é o Limiting Oxygen Index (LOI), que representa a porcentagem de oxigênio mínima necessária para permitir a queima. Quanto mais baixo o LOI, mais facilmente a fibra pode queimar. Para efeito de comparação experimental, Younis (2016) agrupa os valores de LOI das amostras e as classifica de acordo com o percentual de oxigênio conforme a Tabela 4.10. O ar contém 20,9\% de oxigênio, portanto se um material possuir um LOI menor que este valor, ele irá se queimar facilmente quando exposto ao ar, portanto, o valor do oxigênio de 20,90\% pode ser considerado como um limite para agrupamento dos materiais 
Tabela 4.10 - Classificação de LOI frente a inflamabilidade

\begin{tabular}{l|c}
\hline LOI & Classificação \\
\hline LOI $<\mathbf{2 0 , 9 5}$ & Inflamável \\
LOI $=\mathbf{2 0 , 9 5}$ & Marginalmente estável \\
$\mathbf{2 1}<$ LOI $<\mathbf{2 8}$ & Queima Lenta \\
$\mathbf{2 8}<$ LOI $<\mathbf{1 0 0}$ & Auto-extinguível \\
$\mathbf{1 0 0}<$ LOI & Intrinsecamente não inflamável \\
\hline
\end{tabular}

Fonte: YOUNIS, 2016

Fibras naturais como algodão e algumas fibras sintéticas, como o poliéster e náilon têm LOI relativamente baixo entre 18 e 21 . Entretanto, outra fibra natural de origem animal como a lã tem o LOI de $25 \%$ ou fibras sintéticas como as aramidas aromáticas com LOI de 29 - 30\% é mais resistência a chamas (SINCLAIR, 2015) e podem ser observadas na Tabela 4.11.

Tabela 4.11 - Índice LOI para fibras

\begin{tabular}{l|r}
\hline Fibra & \multicolumn{1}{c}{ LOI } \\
\hline Linho & 17.4 \\
Algodão & 18.4 \\
Poliéster & $20.0-21,0$ \\
Seda & 23.0 \\
Lã & 25.2 \\
Trevira CS® & $29.0-30.0$ \\
Para-Aramida & 29.0 \\
Meta-Aramida & $29.0-30.0$ \\
\hline
\end{tabular}

Fontes:Compilado de: Bajaj (2000); Kozlowski; Muzyczek (2012); Sinclair (2015)

Dentre as fibras naturais, a lã apresenta o melhor comportamento de resistência à queima. É uma fibra que apresenta um LOI de $25 \%$ e sua atividade retardante de chamas pode ser associada com a formação de carbono e que pode ser aumentada quando associado a outros elementos químicos (BOURBIGOT, 2008). Como já citado anteriormente, é uma fibra composta de aminoácidos ligados por um peptídeo. As unidades peptídicas são reticuladas por ligações dissulfídicas com grupos reativos tais como amido hidroxilo, imidazol e guanido ligados a eles (KOZLOWSKI; MUZYCZEK, 2012).

A representante das fibras manufaturas é a poliamida aromática com orientação meta no anel fenil, tem menor estrutura linear e redução na energia coesiva e tendência a cristalização PMPI continua sendo um polímero de alto rendimento com alta resistência térmica e mecânica (GARCÍA et al., 2010) e também o PBO caracterizado como uma fibra de alto desempenho, com propriedades físico-químicas superiores em força, módulo, resistência à cortes e altas temperaturas, porém a resistência a flexão, ao 
cisalhamento e módulo de cisalhamento são relativamente baixos. Tais características podem limitar o uso da fibra em algumas aplicações (CAI et al., 2014).

\subsection{RETARDANTES DE CHAMAS}

A abordagem de Weil e Levchik (2009) acompanha a terminologia da ASTM (American Society for Testing and Materials) na qual um elemento retardante de chamas é um produto químico que quando adicionado a um material combustível, retarda a ignição e reduz a propagação das chamas do material resultante quando exposto às chamas. Para os materiais têxteis, o retardante de chamas pode ser um tratamento superficial realizado na fase de beneficiamento ou acabamento (BOURBIGOT, 2008).

A maioria dos materiais, naturais ou sintéticos queima quando expostos a altas temperaturas e a resposta de um polímero a esta exposição depende de sua formulação e a configuração de sua finalidade de uso (EBEWELE, 2000).

Geralmente são adicionados produtos químicos na composição dos polímeros para melhorar as características de inflamabilidade e atender a requerimentos de desempenho específicos (JANSSENS, 2005). A principal finalidade de um retardante de chamas é a preservação da vida e minimizar os danos à propriedade (EBEWELE, 2000)

Também a comercialização de retardantes de chamas torna-se emergente com a necessidade dos fabricantes de plásticos, têxteis e outros materiais atenderem as normas e regulamentos governamentais para melhorar as características de reação às chamas de seus produtos (FINK; TROITZSCH, 2004).

\subsubsection{Modo de ação dos retardantes de chamas}

A abordagem do fogo é bastante sensível, especialmente quando se trata de ambientes fechados como navios ou aeronaves com reduzidas possibilidades de fuga. Também os riscos de incêndio provocados pelos têxteis são consequência de sua grande área de superfície e facilidade de acesso ao oxigênio do ar (BOURBIGOT, 2008).

Para Kozlowski e Muzyczek (2012), as propriedades necessárias para um retardante de chamas ideal são os listados abaixo, embora seja muito difícil encontrar todas usando apenas um produto. Frequentemente um sistema retardante de chamas consiste de vários componentes:

- Alta efetividade na proteção do fogo;

- Estabilidade química quando submetido ao fogo;

- Sem efeito na força mecânica ou estética do material protegido;

- Sem emissão de substancias tóxica ou corrosiva durante o seu uso; 
- Sem aumento na emissão de gases tóxicos ou corrosivos produzidos pela decomposição térmica e combustão;

- Fácil aplicação;

- Se possível, efetivo contra insetos e fungos;

- Resistente à água

- Custo relativamente baixo.

Neste sentido, o comportamento de inflamabilidade dos polímeros e têxteis é definido por vários parâmetros como: a taxa de queima na forma de degradação sólida, a taxa de liberação de calor, taxa de propagação de chamas e características de ignição (BOURBIGOT, 2008).

Para a redução dos riscos de inflamabilidade de um material têxtil, Bourbigot (2008) considera três abordagens: (i) usar têxteis inerentemente retardante de chamas como as fibras de alto desempenho; (ii) usar têxteis modificados quimicamente e (iii) incorporar retardantes de chamas em fibras sintéticas ou fazer tratamento superficial, podendo ser aplicados também em fibras naturais.

Entretanto, tornar um tecido resistente a chamas é um processo complexo, incluindo os tipos de tratamento químicos e a finalidade de uso do produto final. $\mathrm{O}$ produto deverá atender normas de inflamabilidade, as expectativas do cliente quanto ao desempenho, custo, estética e cuidados para a manutenção (WAKELYN, 2008).

Além disso, a maioria das fibras de origem natural é inflamável e os processos listados abaixo foram desenvolvidos para melhorar o comportamento em situação de fogo dos materiais construídos com fibras naturais ou suas misturas com fibras sintéticas. De acordo com Bourbigot (2008):

- Cobertura ou acabamento aplicado para criar uma camada no tecido para proteção da fonte de calor e prevenir a volatilização dos materiais inflamáveis. Forma uma cobertura protetora, tratando o tecido com sais inorgânicos que derretem e formam uma camada vítrea quando exposto a uma fonte de ignição.

- Químicos instáveis termicamente, geralmente carbonatos ou hidratos inorgânicos que são incorporados no material para preservar as características da superfície de carpete ou tecido. Quando exposto a uma fonte de ignição, estes químicos liberam $\mathrm{CO}_{2}$ e/o $\mathrm{H}_{2} \mathrm{O}$, que inicialmente 
diluem e esfriam a chama até a sua extinção e em seguida forma uma camada protetora cerâmica em volta das fibras carbonizadas.

- Materiais que são capazes de dissipar valores significativos de calor são colocados em camadas no tecido ou incorporado em uma estrutura de compósito. Pode ser uma folha de metal ou outro condutor de calor ou um material de mudança de fase (PCM) capaz de absorver uma grande quantidade de calor na medida em que ele decompõe ou volatiliza, fazendo com que o calor seja removido do ponto de exposição e as condições para ignição não é atingida.

- Tratamentos químicos que promovem a formação de carbono, podendo ser reativos ou não reativos, para produzir retardantes de chamas laváveis ou não respectivamente.

- Agentes químicos que liberam sequestradores de radicais livres, geralmente os componentes organo-bromados ou organoclorados que podem ser incorporados no tecido. Estes químicos com o $\mathrm{Br}$ e o $\mathrm{Cl}$ podem interferir na reação de oxidação das chamas e quebrar a cadeia de reação necessária para continuar com a propagação das chamas.

Um retardante de chamas pode inibir ou até suprimir um processo de combustão. Dependendo de sua natureza, a ação pode ser química ou física. Podem ocorrer nas fases sólidas, líquida ou gasosa da combustão. Interferem na combustão durante qualquer estágio, tais como durante a queima, decomposição, ignição ou propagação das chamas (LE BRAS; BOURBIGOT, 2004)

Podem-se classificar os retardantes de chamas em aditivos, reativos e intumescentes. Os aditivos típicos são os halogenados usados sozinhos ou em combinação sinérgica com o óxido de antimônio com o polipropileno, poliéster e o náilon. Ésteres de fosfato, hidratos minerais, ácido bórico, tetraborato de sódio e brometo de amônia. O uso de retardantes de chamas aditivo envolve a adição de materiais inorgânicos de alta fusão para reduzir a inflamabilidade (EBEWELE, 2000).

\section{- Têxteis modificados quimicamente}

Um retardante de chamas pode inibir ou até suprimir um processo de combustão. Dependendo de sua natureza, a ação pode ser química ou física. Interferem na combustão durante qualquer estágio, tais como durante a queima, decomposição, ignição ou propagação das chamas (LE BRAS; BOURBIGOT, 2004) 
A ação química está relativizada com a reação que interferem com o processo de combustão nas fases condensada e gasosa. A reação na fase condensada ocorre com a quebra do polímero acelerada pelo retardante de chamas, retirando sua influência sob a chama (EBEWELE, 2000).

Uma abordagem comum para melhorar a inflamabilidade de um polímero envolve o uso de múltiplos monômeros que são "cross-linked" na matriz do polímero. A decomposição térmica deste copolímero tende a favorecer a formação de carbono, o qual resulta em uma melhor característica de ignição e/ou taxa de liberação de calor (JANSSENS, 2005).

A fibra de poliéster é a mais utilizada em produção industrial em diversas áreas de aplicação. Pode ser utilizada em peças de vestuário, roupas de proteção, tapeçarias, roupas de cama e mesa e cobertura de pisos. Também se caracteriza por ser uma fibra altamente inflamável e uma solução clássica para melhorar as características de reação às chamas é a incorporação de unidade co-monomérica de ácido fosfínico na cadeia do PET (BOURBIGOT, 2008).

Ilustrando esta abordagem, as fibras Trevira CS® e Trevira FR (desenvolvidas por Hoechst $\mathrm{GmbH}$ e comercializadas pela Trevira $\mathrm{GmbH}$ ) são constituídas por um poliéster em que é utilizado um co-monômero retardador de chama (um composto bifuncional organo-fosfórico) na sua copolimerização. A fibra de poliéster com adição de 0,6\% de fósforo apresenta uma LOI de $28 \%$ (superior aos $21 \%$ na atmosfera) e o tecido amolecido pela temperatura não goteja na pele do usuário (BAJAJ, 2000). O mecanismo de ação do fósforo é minimizar a disponibilidade de combustível fresco através da formação de uma camada que limita a transferência de calor e de massa necessária para a propagação da chama e/ ou diminuindo a temperatura da massa fundida do polímero (EBEWELE, 2000).

\subsubsection{Retardantes de chamas fosforados}

O fósforo é conhecido por promover a formação de uma camada carbônica na superfície pela desidratação dos aditivos com base fósforo. O carbono isola o polímero da transferência de calor das chamas. O fósforo também retém alguns radicais nas chamas (JANSSENS, 2005).

Além disso, o fósforo e o boro operam nas fases condensadas e sólidas, minimizando o combustível novo. Eles formam uma camada que limita a transferência 
de calor e massa necessária para a propagação das chamas e abaixa a temperatura de fusão do polímero (EBEWELE, 2000).

De forma geral, o uso de retardantes de chamas não permanente vem causando preocupações ambientais, uma vez que desprendido do artigo em minúsculas partículas, pode ser inalado, ingerido ou até absorvido através da pele humana (BEEN; BASTIAENSEN; LAI; LIBOUSI; THOMAIDIS; BENAGLIA; ESSEIVA; DELE; NUIJS; COVACI, 2018).

\subsubsection{Retardantes de chamas com compostos halogenados}

Retardantes de chamas com compostos halogenados é o maior grupo de aditivos na indústria plástica. Os compostos de bromo e cloro geralmente são os retardantes halogenados mais utilizados (JANSSENS, 2005).

Também se trata do grupo de retardantes de chamas mais utilizados por sua eficiência e baixo custo. Entretanto, alguns produtos halogenados podem ser fontes de dibenzodioxinas tóxicas e dibenzofuranos, razão que tem limitado o seu uso (WANG, 2008).

Tais agentes retardantes de chama com compostos halogenados atuam primeiro na fase gasosa como haletos de hidrogênio inibindo as reações de oxidação da cadeia de radicais na chama. Vários metais, tais como antimônio, bismuto ou estanho são usados como agentes sinérgicos em combinação com os retardantes halogenados, pois os haletos metálicos são inibidores de chamas mais eficientes que os haletos de hidrogênio. Os retardantes de chama bromados vem causando preocupações ambientais nos últimos anos, o qual diminuiu o seu uso (BEEN; BASTIAENSEN; LAI; LIBOUSI; THOMAIDIS; BENAGLIA; ESSEIVA; DELE; NUIJS; COVACI; et al., 2018; JANSSENS, 2005; KHAIRY; LOHMANN, 2018).

\subsubsection{Hidróxidos Inorgânicos}

Cerca de $50 \%$ dos retardantes de chamas vendidos no mundo são hidróxidos inorgânicos, sendo que o tri-hidróxido de alumínio - ATH $\left(\mathrm{Al}(\mathrm{OH})_{3}\right.$ é o mais utilizado, seguido pelo tri-hidróxido de magnésio $\left(\mathrm{Mg}(\mathrm{OH})_{2}\right)$. Uma quantidade significante de energia é necessária para decompor os hidróxidos inorgânicos, gerando uma grande quantidade de água no processo, a qual dilui a concentração dos outros produtos da decomposição gasosa e reduz a temperatura das chamas e reduz significativamente a quantidade de fumaça gerada durante a combustão. (JANSSENS, 2005). 
Com essa abordagem, as características de queima de um polímero podem ser modificadas com alguns compostos, como o tri-hidrato de alumínio, compostos de bromo, parafina clorada, compostos de fósforo e óxidos de antimônio, os quais são usados em conjunto com os compostos de bromo ou cloro (EBEWELE, 2000).

Em alguns casos, o uso de revestimentos contendo retardantes de chamas pode ser usado para proteger produtos como a madeira que não podem passar por tratamento com pressão, ou podem em instalações já existentes e sem tratamento. (JANSSENS, 2005).

\subsection{NORMAS DE INFLAMABILIDADE DOS MATERIAIS TÊXTEIS NA AVIAÇÃO.}

A aviação civil é um setor altamente regulado por leis, padrões, procedimentos, entre outros documentos. Para a segurança do sistema de aviação, os regulamentos são considerados elementos críticos que trazem benefícios para a empresa e seus clientes, pois promovem clareza e certeza das atividades para todos (TYLER, 2015).

Alinhadas para atingir a conformidade com a regulamentação, as características de inflamabilidade dos materiais têxteis empregados na cabine de passageiros da aeronave estão bem definidas na norma CFR 14 e são realizados testes rígidos para avaliar o tempo de propagação da chama. Os materiais que compõem o compartimento de passageiros de uma aeronave em conformidade com o parágrafo $\S 25.853$ - Compartment Interior of CFR 14 - Part 25, deverão apresentar pelo menos os seguintes requisitos: (i) Os materiais devem ser pelo menos resistentes a faíscas (descargas estáticas); (ii) paredes, forros de teto, revestimentos de estofados, pisos e móveis devem ser pelo menos resistentes à chama; (iii) cada receptáculo para toalhas, papel ou resíduos deve ser pelo menos resistente ao fogo e deve restringir o fogo. No entanto, tais regulamentos não citam as matérias têxteis dos uniformes da tripulação (FEDERAL AVIATION ADMINISTRATION, 2018).

As indústrias possuem um moderno sistema de prevenção de incêndios, que seguem extensas regulamentações direcionadas para cada tipo de atividade. No segmento aeronáutico, as regulamentações versam sobre alguns componentes da aeronave, tais como: painéis, carpetes e pisos (TROITZSCH, 1998). As aeronaves com mais de 20 lugares devem ser certificadas de acordo com as normas da regulação "Federal Aviation Regulation (FAR) part. 25" (FEDERAL AVIATION ADMINISTRATION, 2018) emitida pelo órgão "Federal Aviação Administration" (FAA) ou outros órgãos acreditadores dos países de origem ou de atividades da aeronave. Tomando como 
parâmetro uma aeronave Airbus 320, com capacidade de 156 a 180 passageiros, a FAR 25 será o regulamento de referência a ser utilizado neste estudo. A FAR 25 é reconhecida pelas principais agências de aviação civil do mundo, inclusive a ANAC - Agência Nacional de Aviação Civil. Os requisitos de proteção ao fogo como extintores de incêndio, sensores de fumaça e materiais são tratados na "Subpart D - Design and Construction", do FAR 25 e as especificações de ensaios são descritas no seu Apêndice F com a divisão da aeronave em cinco partes. Estas, referentes a compartimentos interiores, são: cabine de passageiros, cabine dos pilotos - cockpit, galley, área de descanso da tripulação, lavatórios e compartimento de carga (Figura 13).

Figura 13 - Cabine Airbus A320 - Mapa de Assentos

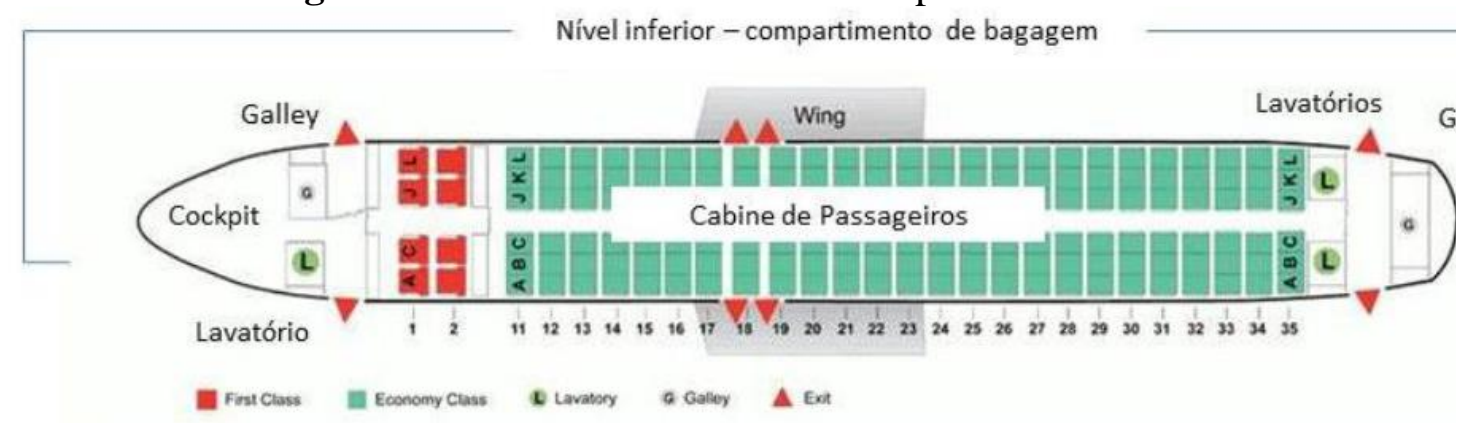

Fonte: Aviation Explorer (2015)

Os materiais têxteis utilizados no compartimento de passageiros das aeronaves Airbus A320 integram os componentes do conceito de "Cabin Interior Crashworthiness", que neste contexto denota a incorporação no projeto básico de considerações pertinentes a proteção dos ocupantes do avião em um ambiente de sobrevivência ao desastre.

Este ambiente prevê que quando o ocupante da cabine (o passageiro) for o objeto das forças durante um desastre, estas fiquem dentro do nível humano aceitável de segurança e a integridade estrutural do espaço do passageiro se mantenha intacto, enquanto o ocupante é rapidamente evacuado da aeronave (U.S. DEPARTMENT OF TRANSPORTATION; FEDERAL AVIATION ADMINISTRATION, 2016). Historicamente, os testes estáticos para aprovação das estruturas e componentes das aeronaves foram privilegiados até o período do pós-Segunda Guerra Mundial, quando o conceito de crash worthiness, ou seja, um ambiente que absorva a energia do impacto durante um desastre, começou a ter maior atenção e expandiu nos anos seguintes. Uma mudança significativa acorreu em 1967, quando a "Federal Aviation Administration" (FAA), editou uma série de normas para crashworthiness para o setor aeronáutico, 
abordando três áreas (U.S. DEPARTMENT OF TRANSPORTATION; FEDERAL AVIATION ADMINISTRATION, 2016)

- Proteção dos ocupantes do avião em caso de impacto;

- Minimizar a evolução e severidade de potencial fogo a bordo;

- Evacuação rápida dos ocupantes do avião em caso de desastre.

Os materiais que irão compor o compartimento de passageiros de uma aeronave buscando a conformidade com o "§ 25.853 - Compartment Interior" da FAR 25 devem apresentar no os seguintes requisitos (FEDERAL AVIATION ADMINISTRATION, 2018):

- Os materiais devem ser no mínimo resistentes à faísca (descarga de eletricidade estática);

- As paredes, forro de teto, cobertura dos estofados, pisos e mobília devem ser no mínimo resistentes à chama;

- Cada receptáculo para toalhas, papel ou resíduo deve ser no mínimo resistente ao fogo e deve conter o fogo.

\subsection{TESTES DE INFLAMABILIDADE EM TÊXTEIS}

A preocupação com com a inflamabilidade dos materiais têxteis, inicia-se com a edição do Flammable Fabrics Act (FFA) em 1953 pelo governo norte americano. Especificava um testes, uma norma comercial voluntária chamada de Flammability of Clothing Textile, Commercial Standard (CS) usado para determinar se um tecido ou roupa é altamente inflamável para ser usados pelo consumidor (STEVENSON, 2008).

Hoje com o nome de Standard for the Flammability of Clothing Textiles, 16 CFR part 1610 (ELETRONIC CODE OF FEDERAL REGULATIONS, 2018) permite classificação dos materiais têxteis em relação ao tempo de queima, que é influenciado pelo tipo de fibra (natural ou manufaturada) e o tipo de construção, envolvendo ligamento, gramatura e densidade do tecido (SPEECE, 1974). Também o acabamento e o design da peça podem afetar a inflamabilidade da roupa ou produto têxtil (BOURBIGOT, 2008).

Os resultados obtidos com este ensaio, possibilita classificar os materiais têxteis em acceptable flammability e not acceptable flammability, testando cinco amostras, submetendo-as às chamas por tempo determinado. O teste é realizado com corpo de prova de 50x150 mm, em um gabinete com dispositivos para posicionamento das amostras, registro do tempo de queima e sistema de parada do cronômetro. Os requisitos da parte 
1610 são aplicáveis aos produtos têxteis ou material relacionado, no estado pronto para uso em um artigo de vestuário, incluindo roupas e trajes acabados para utilização pelos consumidores e um resumo da classificação está demonstrado na Tabela 4.12. (ELETRONIC CODE OF FEDERAL REGULATIONS, 2018).

Tabela 4.12 - Resumo dos critérios de teste para classificação das amostras em termos de tempo de queima em segundos (s)

\begin{tabular}{c|cc}
\hline \multicolumn{1}{c}{ Classe } & $\begin{array}{c}\text { Tecido com superfície } \\
\text { Plana }\end{array}$ & $\begin{array}{c}\text { Tecido com superfície elevada } \\
\text { (Texturas e Relevos) }\end{array}$ \\
\hline 1 - ACEITÁ VEL & Tempo de queima $\geq 3,5 \mathrm{~s}$ & $\begin{array}{c}\text { Tempo de queima }>7,0 \mathrm{~s} \\
\text { ou tempo de queima de } 0-7,0 \mathrm{~s} \text { sem } \\
\text { queimadura na base do tecido. }\end{array}$ \\
2 - ACEITÁ VEL & $\begin{array}{c}\text { Classe } 2 \text { não é aplicável a } \\
\text { tecidos com superfície plana }\end{array}$ & $\begin{array}{c}\text { Tempo de queima de } 4,0-7,0 \mathrm{~s} \mathrm{com} \\
\text { queimadura na base do tecido. }\end{array}$ \\
3 - NÃO & Tempo de queima $<3,5 \mathrm{~s}$ & $\begin{array}{c}\text { Tempo de queima }>4,0 \mathrm{~s} \text { com queimadura na } \\
\text { base do tecido. }\end{array}$ \\
\hline
\end{tabular}

Fonte: Adaptado de U.S. Department of transportations (2016); Federal Aviation Administration (2016)

Outra abordagem para testes de inflamabilidade é a verificação do comportamento de queima, utilizando as normas ISO 6940:2004 - Textile Fabrics - Burning behaviour Determination of ease of ignition of vertically oriented specimens e ABNT NBR ISO 15025: 2016 - Vestimentas de Proteção contra calor e chamas - Método de ensaio para a propagação limitada de chamas. No procedimento A, a ignição é realizada na superfície e no procedimento $\mathrm{B}$, a ignição é realizada na borda inferior da amostra.

Este teste é utilizado para estudar o padrão de propagação da chama até a borda do corpo de prova. Também é possível determinar o tempo de pós chama, tempo e expansão da incandescência residual, se os resíduos inflamam o papel filtro e no caso de aplicação da chama horizontal, se é suficiente para fazer um furo. Permite detectar dois grupos de tecidos, aqueles que produzem pouco ou nenhum pós-chama e tecidos que queimam em toda a sua extensão. Os corpos de prova têm dimensões de 70x190mm para a ISO 6940:2004 e 150x190 mm para a NBR ISO 15025:2016.

Também é possível medir a velocidade de propagação das chamas no material têxtil. A norma ISO 6941:2003 - Textile Fabrics - Burning behaviour - Measument of flame spread properties of vertically oriented specimens. Este método é usado para comparar os tempos de propagação da chama de diferentes materiais têxteis inflamáveis.

O ensaio é realizado em corpos-de-prova de 170x560mm. Aplica-se a chama por 10 segundos e após retirada a fonte, registra-se o tempo de queima entre os três marcadores. A precisão do método dependente do tipo de material a ser testado, pois não 
se pode garantir taxas de propagação de chamas constantes. A ignição exige um tempo mínimo, no qual não há propagração e após a ignição há um período de crescente intensidade e aceleração da chama.

Caso a chama se espalhe por toda a largura da amostra, a taxa de propagação tornase aproximadamente constante. O material termoplástico das fibras sintéticas pode derreter e cair fazendo com que a propagação da chama diminua ou pare. Quando isso acontece, as linhas de marcação não são atingidas e a velocidade não pode ser calculada.

Já a norma francesa NF G07-182 - Textiles - Comportement au feu Détermination des propriétés de propagation de flamme sur éprouvettes orientées à 45 degrés - Mesurage de la vitesse de propagation de flamme. O corpo-de-prova é de 160x600mm. A ignição é iniciada através de um pavio feito de tecido misto 67\%PES e $33 \%$ CO. A distância de $500 \mathrm{~mm}$ é marcada por duas linhas, que ao serem queimadas iniciam e terminam a contagem de tempo. Com os valores de espaço percorrido pela chama e o tempo que levou, é possível calcular a velocidade de propagação da chama. 


\section{MATERIAIS E MÉTODOS}

\subsection{LEVANTAMENTO BIBLIOGRÁFICO E DOCUMENTAL E EXPERIMENTAL}

A realização do presente estudo utilizou uma abordagem conceitual exploratória que de acordo com Gil (2002), constrói maior familiaridade com o problema, aprimorando as ideias e tornando-o mais explícito objetivando contextualizar o uso de uniformes na aviação civil. Também será utilizada a abordagem explicativa, cuja preocupação fundamental é identificar os fatores que contribuem ou agem como causa para a ocorrência de determinados fenômenos.

As informações de fontes primárias como as leis, normas e procedimentos aplicados ao tema contribuíram para a análise documental vigente na aeronáutica, atividade cuja característica é a alta regulamentação.

Outras informações foram obtidas por meio de entrevista informal, com estrutura flexível a qual possibilita ao entrevistador adequar-se às pessoas e as circunstâncias (GIL, 2008). Conforme Marconi e Lakatos (2007): "É uma forma de poder explorar mais amplamente uma questão. Em geral, as perguntas são abertas e podem ser respondidas dentro de uma conversação informal".

Em adição, Marconi e Lakatos (2003), indicam as peças de uniforme (vestuário) como itens a serem considerados como objetos documentais, pois demonstram o significado dos materiais, técnicas de confecção, adornos e cores, entre outras características.

Outro procedimento para coleta de dados foi a pesquisa experimental, a qual busca verificar a relação de causalidade estabelecida entre as variáveis independentes e a resposta (GIL, 2002). Para tanto, os experimentos foram realizados em condições controladas.

Some-se a isto a abordagem bibliográfica, coletando dados secundários e situando as discussões acadêmicas sobre o problema e também as definições de tópicos comuns. Tal abordagem, como descrito por Gil (2002) propõe uma análise das diversas posições sobre o tema, abrindo as possibilidades para o pesquisador direcionar seus passos. 


\subsection{MATERIAIS}

\subsubsection{Uniforme de Aeronautas.}

Durante o período de fevereiro de 2016 até março 2017, foi realizada a coleta de uniformes de comissários de voo e de amostras de tecidos com o objetivo de caracterizar os materiais utilizados na confecção dos uniformes. Após a documentação fotográfica e caracterização das peças de uniforme, elas foram descosturadas e os seus materiais submetidos a experimentos laboratoriais para a caracterização físico-química.

Em visita a uma confecção situada na cidade de São Paulo, atualmente fornecendo uniformes para serviços aeronáuticos e regaste, foi abordado o histórico dos seus clientes antigos. Foi constatado que no começo das suas atividades no final da década de 1990 a empresa forneceu os uniformes para os comissários de Voo de uma Linha Aérea, atuante no mercado brasileiro, que será denominada como Linha Aérea A, nas abordagens do presente estudo. A confecção doou duas camisas femininas doravante denominadas P1 e P2 assim como uma camisa masculina nomeada P3.

De igual maneira, foi doado um conjunto de peças por um ex-funcionário de outra Linha Aérea, a qual encerrou as suas atividades em meados dos anos 2000 e que será identificada como a letra "A". Trata-se de um conjunto completo de uniforme de comissário de voo masculino composto de duas camisas (P4 e P5), um paletó (P6) que combina com as calças (P7) e um paletó avulso (P8).

Para garantir a fiel identificação do material têxtil, foi desenvolvido o método para registro das amostras, documentando as informações em uma ficha (Apêndice A). Os campos a serem preenchidos são: foto da peça, a identificação com código numérico (P1 a P8), uma breve descrição do modelo, Linha Aérea do uniforme, tamanho, o material descrito na etiqueta e o estado das peças.

\subsubsection{Tecidos comerciais para uniformes.}

Para a preparação dos ensaios destrutivos e validação do protótipo para testes de chamas foram necessárias quantidades maiores de material têxtil e para tanto foi conduzida uma análise preliminar das amostras obtidas dos uniformes dos aeronautas. Tal abordagem indicou a utilização de: (i) tecido de algodão com gramatura pesada; (ii) tecido misto de algodão e poliéster com gramatura leve para as camisas e (iii) tecido $100 \%$ poliéster para os casacos masculinos e femininos. Assim, foram adquiridos de tecidos similares, correspondentes respectivamente a T1, T2 e T3 com o propósito para realizações preliminares dos testes destrutivos e validação de protótipo para teste de 
chamas de modo que material escasso dos uniformes profissionais seja preservado. As suas características básicas estão descritas a seguir:

- T1 - Fornecedor Constâncio Vieira, Linha Profissional Sarja Work, material $100 \%$ algodão, gramatura $264 \mathrm{~g} / \mathrm{m}^{2}$, largura: $1,62 \mathrm{~m}$ e ligamento sarja $3 \times 1$;

- T2 - Fornecedor: Focus Têxtil, Linha Profissional, utilizado para confecção de jalecos de médicos, enfermeiros, roupas, saias, calças, vestidos e blazers, material100\% Poliéster, gramatura $173 \mathrm{~g} / \mathrm{m}^{2}$, largura $1,50 \mathrm{~m}$ e ligamento sarja $3 \times 1$;

- $\quad$ T3 - Fornecedor Toyobo do Brasil, Linha Profissional - Worker New, material: $67 \%$ poliéster $33 \%$ algodão, gramatura $112 \mathrm{~g} / \mathrm{m}^{2}$, largura: 1,60 $\mathrm{m}$, ligamento tela.

\subsection{MÉTODOS.}

\subsubsection{Contato com as Linhas Aéreas.}

$\mathrm{Na}$ tentativa de se estabelecer contato institucional com as Linhas Aéreas que atuam no Brasil, nos meses de agosto e setembro de 2016, foi solicitada por meio do canal virtual disponível no site de cada Linha Aérea, a oportunidade de expor o estudo sobre os uniformes em uma reunião, conhecer o processo de desenvolvimento dos uniformes e escolha dos materiais têxteis e também solicitar uma amostra do uniforme.

Durante o processo, surgiu a oportunidade para envio de uma carta da Direção da EACH para uma das empresas, via o setor de Gestão de Resíduos, porém desde outubro de 2016 e após diversos telefonemas pedindo informações não se obteve resposta.

Novamente em novembro de 2017 e abril de 2018, foram enviadas mensagens eletrônicas solicitando novamente a oportunidade de contato, com o objetivo de se estabelecer contato institucional e novamente solicitando uma visita e entrevista com as pessoas responsáveis pelas especificações e compra dos uniformes dos aeronautas. Tais reuniões poderiam contribuir na compreensão da abordagem técnica do material dos uniformes e como ela contribui para a atuação dos aeronautas em situação de combate de fogo a bordo e reforçando a ideia de trazer para a pesquisa acadêmica a visão das empresas.

\subsubsection{Entrevistas}

Durante o levantamento documental e bibliográfico, as regras de usos e cuidado com o uniforme, inclusive os procedimentos de troca se configuraram como um elemento importante para as Companhias Aéreas. Para compreensão do assunto, foi realizada uma entrevista no dia 18/11/2016 com Sr. Lucas Corvacho da empresa Retalhar, a qual oferece 
soluções para descarte de uniformes profissionais e entre seus clientes estão as principais Linhas Aéreas operando no estado de São Paulo.

Em adição, foi realizada entrevista em 26/01/2017 com o Prof. Dr. Donizete de Andrade do Instituto Tecnológico da Aeronáutica (ITA), especialista em segurança de voo com o propósito de estabelecer a probabilidade de ocorrência de acidentes com fogo a bordo e danos semelhantes aos estabelecidos no presente estudo.

Em ambos os casos houve autorização para a divulgação das informações e nomes dos entrevistados. As entrevistas foram gravadas e transcritas. Uma cópia da transcrição foi enviada ao entrevistado para verificação e comentários.

\subsubsection{Visita Técnica}

Com o objetivo de adquirir mais informações sobre ensaios de inflamabilidade, no dia 19 de junho de 2017 foi realizada a visita técnica ao laboratório de Física Têxtil do CITEVE Tecnologia Têxtil, localizada na cidade de Vila Nova de Famalicão, em Portugal, visita essa organizada pela Sra. Manuela Pereira (CITEVE) e o Engenheiro Joaquim Jorge Peixoto (UMINHO). A Engenheira Suzana Blattman apresentou os equipamentos e os testes realizados com objetivo de certificação de produtos inclusive as normativas ABNT NBR ISO 15025: 2016 - Vestimentas de Proteção contra calor e chamas - Método de ensaio para a propagação limitada de chamas e 16CFR Part 1610 - Standards for the flammability of clothing textile, assim como outras instalações e equipamentos daquele renomado centro.

Foram apresentados os equipamentos de teste de chamas que atendem a mais de quinze normativas atualmente em vigência, inclusive com uma cabine para atender várias normas com as suas especificidades de tamanhos de amostras.

\subsubsection{Características dos uniformes de aeronautas}

\subsubsection{Registro Fotográfico dos uniformes dos aeronautas.}

Os registros fotográficos foram obtidos por meio de fotografias digitais realizadas pela autora. Foram utilizados os seguintes equipamentos e ajustes: Câmera EOS 60D Canon, tempo de exposição 1/100 s, velocidade ISO-1000, distância focal 50 mm. Iluminação por dois focos de luz difusa (soft box). 


\subsubsection{Dimensionamento dos uniformes dos aeronautas.}

A caracterização das peças dos uniformes iniciou-se com o dimensionamento adotado pela norma ABNT NBR 12071:2002 - Artigos Confeccionados para vestuário Determinação das dimensões (ASSOCIAÇÃO BRASILEIRA DE NORMAS TÉCNICAS, 2002). De acordo com a norma, cada peça foi disposta em uma superfície plana e horizontal e com uma régua metálica foram verificadas as onze medidas ilustradas na Figura 14 para camisas e blusas, sendo (1) comprimento do ombro, (2) tórax/busto, (3) cintura externa, (4) cava, (5) comprimento total manga, (6) abertura da barra da manga - incluindo o punho - se houver, (6) abertura da barra da manga, (7) gola, (8) largura de ombro a ombro, (9) largura das costas, (10) comprimento total traseiro, (11) comprimento total dianteiro.

Figura 14 - Esquema para medição de camisa e blusa
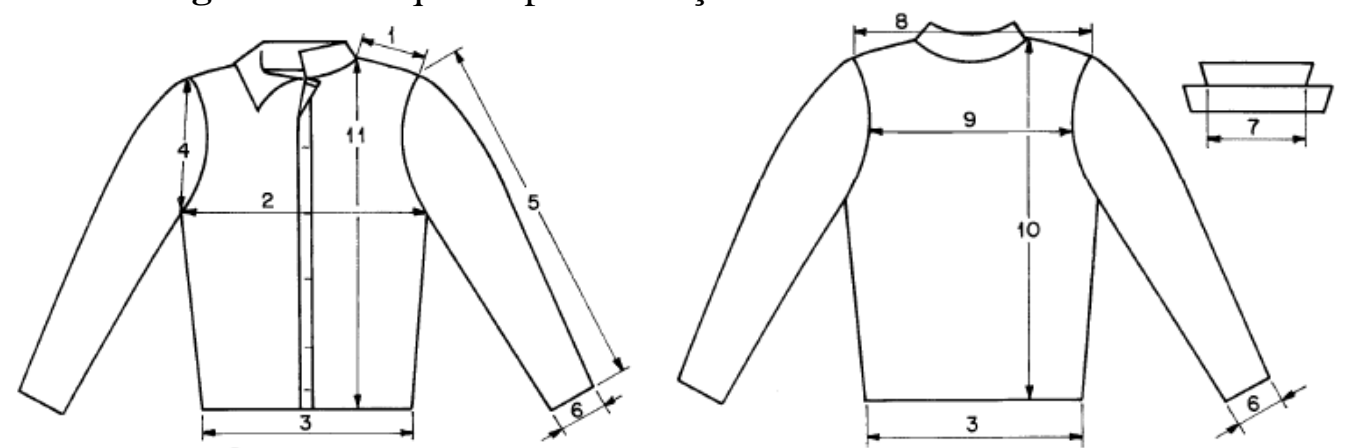

Fonte: Associação Brasileira de Normas Ténicas (2002)

Para a calça (Figura 15), as medidas indicadas na norma são: (1) cintura externa, (2) quadril - $7 \mathrm{~cm}$ acima da junção do gancho, (3) comprimento entre pernas, (4) comprimento do gancho dianteiro, (5) quadril alto $-3 \mathrm{~cm}$ abaixo do cós, excluindo-o, (6) comprimento do gancho traseiro, (7) coxa $-2 \mathrm{~cm}$ abaixo da junção do gancho, (8) abertura da barra, (9) comprimento total - excluindo o cós.

Figura 15 - Esquema para medição de calça
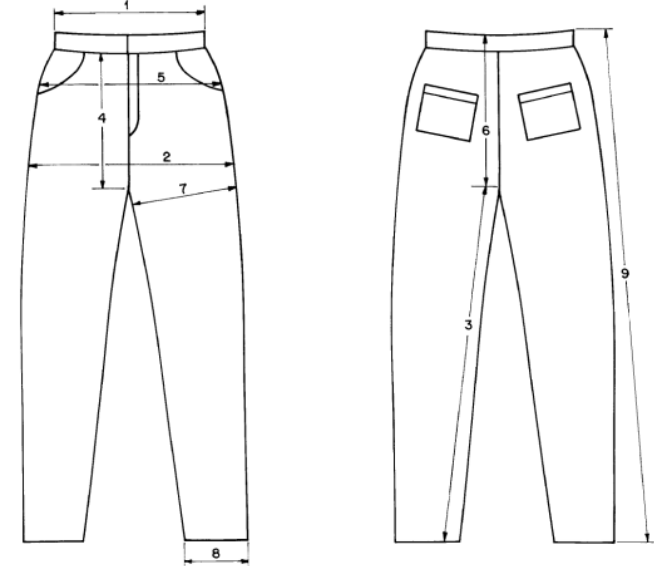

Fonte: Associação Brasileira de Normas Ténicas (2002) 


\subsubsection{Caracterização do material têxtil aplicado aos uniformes dos aeronautas e tecidos profissionais}

\subsubsection{Composição da Fibra Têxtil: Etiqueta e por FTIR (Fourier Transform Infrared Spectroscopy)}

Os uniformes e os tecidos passaram por uma análise visual e informação da composição têxtil foi obtida da etiqueta do produto, uma vez que tal informação é obrigatória para artigos confeccionados têxteis no Brasil conforme norma ABNT NBR NM IS 3758:2013 (ASSOCIAÇÃO BRASILEIRA DE NORMAS TÉCNICAS, 2013).

A fim de confirmar as composições declaradas nas etiquetas, uma amostra de no mínimo cinco gramas do tecido de cada uniforme (P1 a P8) e dos tecidos adquiridos no mercado (T1 a T3) foi analisada pela técnica de espectroscopia na região do infravermelho médio (700 a $4000 \mathrm{~cm}^{-1}$ ). O equipamento utilizado de marca Thermo, modelo Avatar 370 FTIR, utilizando célula de ATR/ Germânio (Ge) (Nicolet, EUA) e software Omnic, versão 4.1 para comparação com os padrões armazenados na biblioteca do equipamento (THERMO ELECTRO CO., 2004).

\subsubsection{Ligamento.}

A determinação do ligamento, ou seja, a forma de entrelaçamento dos fios de trama e urdume dos tecidos (T1 a T3) e das peças dos uniformes (P1 a P8), seguiu o protocolo estabelecido pela Norma ABNT 12996:1993 - Materiais Têxteis; Determinação dos ligamentos fundamentais de tecidos planos (ASSOCIAÇÃO BRASILEIRA DE NORMAS TÉCNICAS, 1993). Com uma lente conta-fios, aumento de 10 vezes e a ajuda de agulhas para separação dos fios, foi possível identificar as construções dos tecidos. Cada tecido foi avaliado com o objetivo de encontrar o padrão de repetição de trama e urdume. Os ligamentos fundamentais para tecidos planos são: tela ou tafetá $(1 \times 1)$, sarja $(2 \times 1$ ou $3 \times 1)$ e cetim ( $4 \times 1$ ou superior) conforme ilustrado na Figura 16 e suas variações. 
Figura 16 - Ligamento ou Debuxo: (a) Tela ou Tafetá; (b) Sarja; (c) Cetim.

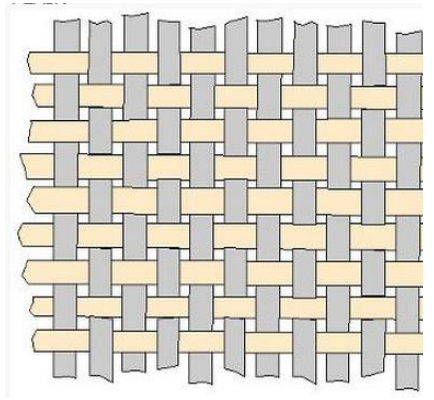

(a)

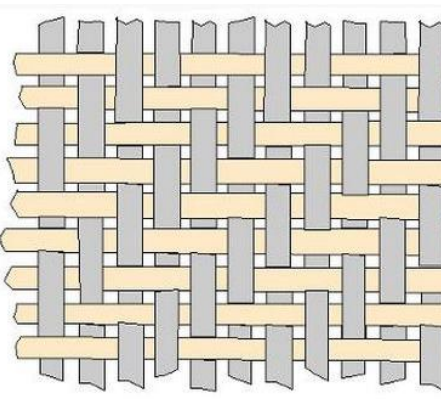

(b)

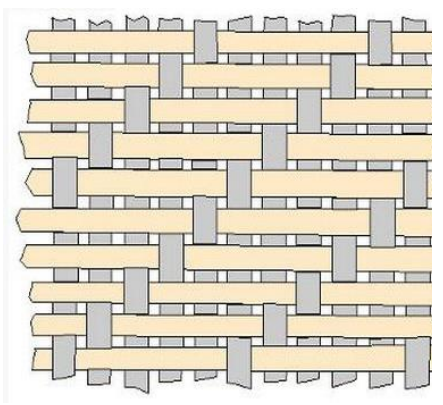

(c)

Fonte: Carbon E.E. (2015)

O corpo-de-prova foi desfiado até formar uma franja de aproximadamente $2 \mathrm{~mm}$ e, com o auxílio de uma lente conta-fios e de um estilete ou agulha, o primeiro fio de urdume foi retirado e a evolução foi anotada em papel quadriculado, considerando os pontos tomados e os deixados. Subsidiariamente foram utilizadas nesta análise a Norma Portuguesa NP 4114:1991 (INSTITUTO PORTUGUÊS DA QUALIDADE, 1991) e Norma ISO 7211-1:1984 (INTERNATIONAL ORGANIZATION FOR STANDARDIZATION, 1984a).

\subsubsection{Determinação número de fios por trama e urdume}

A densidade de fios indica quantos fios foram alinhados por centímetro no tecido para a sua formação. O ensaio foi realizado de acordo com a norma NBR ABNT 10588:2015 - Tecidos planos - Determinação da densidade de fios (ASSOCIAÇÃO BRASILEIRA DE NORMAS TÉCNICAS, 2015). Esta é uma informação necessária para cálculo do fator de cobertura do tecido. Uma lente conta-fios com base graduada em 1 $\mathrm{cm}$, fabricante Intex (Figura 17), foi utilizada para contar os fios de trama e urdume de cada amostra de tecido em cinco lugares diferentes.

Figura 17 - Lente conta fios com base graduada de $1 \mathrm{~cm}$ e aumento de 10 vezes, Intex Brasil

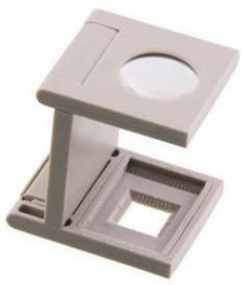


Subsidiariamente foram utilizadas nesta análise a Norma Portuguesa NP EM 1049-2: 1995 e Norma ISO 7211-2:1984 (INTERNATIONAL ORGANIZATION FOR STANDARDIZATION, 1984b).

\subsubsection{Espessura}

A medição de espessura foi realizada conforme determinado na norma $\mathrm{ABNT}$ NBR 13371:2005 - Materiais têxteis - Determinação da espessura (ASSOCIAÇÃO BRASILEIRA DE NORMAS TÉCNICAS, 2005). Foram utilizadas as amostras dos tecidos retiradas dos uniformes dos aeronautas e dos tecidos profissionais. Por se tratar de amostras pequenas, a medição de cada amostra foi feita em dez lugares diferentes sem destruí-las. Foi utilizado o medidor de espessura analógico portátil, aparelho também conhecido como espessímetro (modelo 7321, Mitutoyo, Japão) com precisão 0,01mm e pressão das garras pré-estabelecida em $18 \mathrm{~Pa}$.

\subsubsection{Gramatura}

A gramatura de um tecido é expressa em massa por unidade de área. Para o presente estudo a obtenção da gramatura seguiu os protocolos da norma ABNT NBR 10591:2008 - Determinação da gramatura de superfícies têxteis (ASSOCIAÇÃO BRASILEIRA DE NORMAS TÉCNICAS, 2005). Também é possível fazer uma classificação por atributo para as faixas de gramatura conforme a Tabela 5.1.

Tabela 5.1 - Faixas de gramatura $\left(\mathrm{em} \mathrm{g} / \mathrm{m}^{2}\right)$ definindo têxteis como de gramatura leve, média, pesada ou extra-pesada.

\begin{tabular}{c|c}
\hline Gramatura & Valores $\mathbf{( g / \mathbf { m } ^ { 2 }}$ \\
\hline Leve & $0-129,9$ \\
Média & $130,0-204,9$ \\
Pesada & $205,0-273,9$ \\
Extrapesada & Acima de 274 \\
\hline
\end{tabular}

Fonte: Adaptado de Aldrich (2013)

Os ensaios de gramatura foram realizados em duas etapas. A primeira foi conduzida no Laboratório de Física Têxtil do Departamento de Engenharia Têxtil da Universidade do Minho, com cinco corpos-de-prova retirados dos tecidos comprados (T1 a T3). As amostras foram colocadas em sala climatizada e posteriormente pesadas na balança Kern 770, carga máxima 120 g e divisão de 0,0001g.

A segunda etapa foi realizada no Laboratório de Laboratório de Caracterização Têxtil da Escola de Artes, Ciências e Humanidade da Universidade de São Paulo, com 10 
corpos-de-prova retirados das peças de uniforme (P1 a P8). As amostras foram climatizadas conforme normas (i) ABNT NBR ISO 139:2005 - Têxteis - Atmosferas Padrão para condicionamento de ensaios (ASSOCIAÇÃO BRASILEIRA DE NORMAS TÉCNICAS, 2008) e (ii) ABNT NBR 12331:1991 - Fibras Têxteis - Taxa convencional de acondicionamento - Padronização (ASSOCIAÇÃO BRASILEIRA DE NORMAS TÉCNICAS, 1991). Desta forma, o período mínimo de climatização constituiu em 48 horas a $20^{\circ} \mathrm{C}$ e umidade relativa de $65 \%$ em climatizadora (Mesdan, modelo Climatest M250 - RH, Itália).

Retirados da climatizadora, os corpos-de-prova foram imediatamente pesados em balança analítica de 4 casas (Sartorius, modelo ED 1245, Alemanha) e a gramatura individual calculada conforme Equação 4.

$$
\begin{array}{lll}
\text { Gramatura }=\bar{M} \times 100 & \text { (Equação 4) } & \begin{array}{l}
\text { Onde: } \\
\dot{M}=\text { Média das massas das amostras } \\
\text { determinadas em amostras de } 100 \mathrm{~cm}^{2}(\mathrm{~g})
\end{array}
\end{array}
$$

\subsubsection{Determinação da densidade linear}

Conforme norma ISO 7211/5: 1984 (INTERNATIONAL ORGANIZATION FOR STANDARDIZATION, 1984e) Este teste foi realizado junto com o teste de contração ou Crimp Test ISO 7211/3: 1984 (INTERNATIONAL ORGANIZATION FOR STANDARDIZATION, 1984c). Foram extraídos 11 fios de trama e 11 fios de urdume de cada tecido. Houve uma variação na largura dos tecidos de acordo com a disponibilidade da amostra, com $50 \mathrm{~cm}$ ou $30 \mathrm{~cm}$. Após conduzir o teste de pré-tensão e determinar a carga, cada fio foi pesado e o valor de sua densidade linear em tex, o qual significa gramas por 1.000 metros de fio.

\subsubsection{Determinação da contração}

Determinações do crimp de um fio retirado de um tecido conforme ISO 7211/3: 1984.(INTERNATIONAL ORGANIZATION FOR STANDARDIZATION, 1984c). Utiliza-se o aparelho de Crimp Tester Maillemetre, ilustrado na Figura 18. Tal aparelho permite determinar a contração de um fio retirado de um tecido. A contração é a diferença entre a largura do tecido e o comprimento medido do fio retirado do tecido após aplicação de uma carga estabelecida. 
Figura 18 - Crimp Tester marca Maillemetre

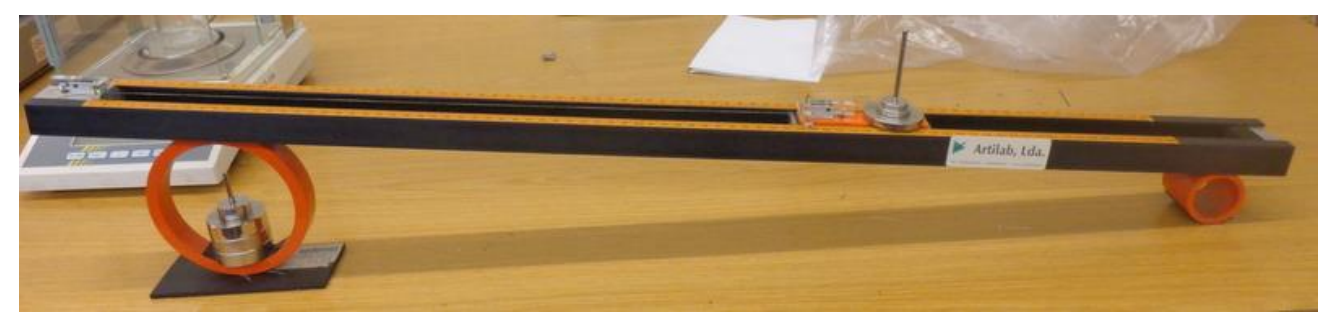

Fonte: Marcia Cristina Silva (2017).

De cada tecido foram retirados 11 fios de trama e 11 fios de urdume, na largura de $50 \mathrm{~cm}$ ou $30 \mathrm{~cm}$, dependendo do material disponível para teste, sendo que um fio é utilizado para cálculo da pretensão a ser utilizada no ensaio. A recomendação no catálogo do fabricante é uma combinação de cargas 8 e 2 a qual aplica uma tensão de $15 \mathrm{gf}$. Com o comprimento do fio e o peso é possível calcular o título do fio. Com o valor do título calcula-se a tensão que será aplicada durante o teste, de acordo com a Equação 5.

$$
\text { Tensão }=(0,2 \times \text { título })+4
$$

(Equação 5)

Com o valor da tensão calculado, os valores de carga utilizados no aparelho foram selecionados de acordo com a Tabela 5.2.

Tabela 5.2 - Combinação de Cargas

\begin{tabular}{rrrrrrrrr}
\hline Cargas & $\mathbf{0}$ & $\mathbf{1}$ & $\mathbf{2}$ & $\mathbf{1 + 2}$ & $\mathbf{4}$ & $\mathbf{1 + 4}$ & $\mathbf{2 + 4}$ & $\mathbf{1 + 2 + 4}$ \\
\hline $\mathbf{0}$ & 5 & 6 & 7 & 8 & 9 & 10 & 11 & 12 \\
$\mathbf{8}$ & 13 & 14 & 15 & 16 & 17 & 18 & 19 & 20 \\
$\mathbf{1 6}$ & 21 & 22 & 23 & 24 & 25 & 26 & 27 & 28 \\
$\mathbf{8 + 1 6}$ & 29 & 30 & 31 & 34 & 33 & 34 & 35 & 36 \\
$\mathbf{1 6 + 1 6}$ & 37 & 38 & 39 & 40 & 41 & 42 & 43 & 44 \\
$\mathbf{8 + 1 6 + 1 6}$ & 45 & 46 & 47 & 48 & 49 & 50 & 51 & 52 \\
$\mathbf{1 6 + 1 6 + 1 6}$ & 53 & 54 & 55 & 56 & 57 & 58 & 59 & 60 \\
$\mathbf{8 + 1 6 + 1 6 + 1 6}$ & 61 & 62 & 63 & 64 & 65 & 66 & 67 & 68 \\
\hline
\end{tabular}

Fonte: Catálogo do Fabricante Maillemetre (s.d.)

\subsubsection{Determinação da torção}

Conforme ISO 7211/4: 1984 (INTERNATIONAL ORGANIZATION FOR STANDARDIZATION, 1984d). Para os fios open end e quando foi possível retirar uma amostra de $70 \mathrm{~cm}$, foi utilizado o equipamento Twistronic do Fabricante Mesdan (Figura 19). O fio é colocado nas mandíbulas do equipamento que exercem a distorção e a torção do fio e o valor é apresentado no painel eletrônico. 
Figura 19 - Twistronic marca Mesdan

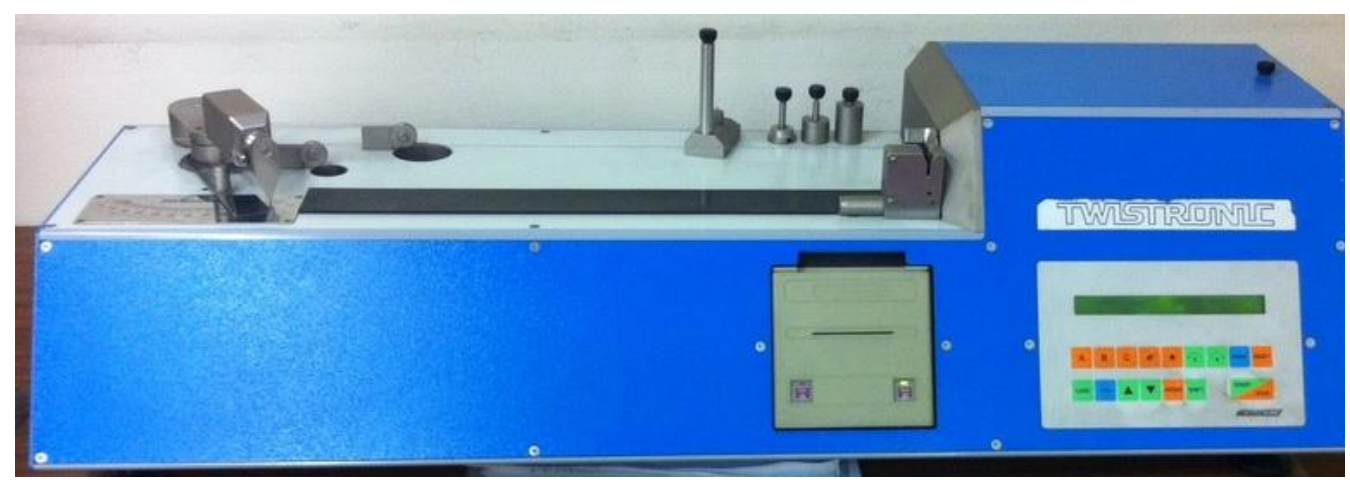

Fonte: Marcia Cristina Silva , 2017.

Para as amostras menores que $70 \mathrm{~cm}$, fomos utilizados o equipamento Torciômetro ou Torcímetro do Fabricante James H. Heal \& Co Ltda.

O comprimento utilizado e padronizado para os demais testes foi de $20 \mathrm{~cm}$. O fio é preso no fixador e em seguida adicionado um peso. A primeira etapa do teste serve para identificar o sentido da torção se "Z" ou "S". Também se verifica a posição na qual o fio se rompe e coloca-se o limitador. Para fios comuns, ao acionar o aparelho ele distorce o fio até o limite de quebra e então começa a torcer novamente. Quando o indicador chega ao ponto zero, é feita a leitura no contador de voltas.

Para os fios retorcidos, ao distorcer e separar os fios, com a ajuda de uma agulha entre os cabos, continua-se até que os cabos fiquem paralelos. Neste momento, a leitura do contador demonstra o valor de torções por $20 \mathrm{~cm}$.

\subsubsection{Medição do Diâmetro dos fios por microscopia ótica.}

\section{- Vista Longitudinal}

As vistas longitudinais foram realizadas com os fios retirados no sentido da trama e do urdume de cada peça de uniforme, presas por uma cartolina devidamente recortada, colada e identificada, com aproximadamente $40 \mathrm{~mm}$ por $25 \mathrm{~mm}$ (medidas externas) e $30 \mathrm{~mm}$ por $15 \mathrm{~mm}$ (medidas internas). A análise foi realizada em estéreomicroscópio (Leica, modelo MS5, Alemanha) acoplado a videocâmara de captação digital de imagens (Vista, Protos IV, modelo VPC 122/CH, 1/2'" CCD, Grã-Bretanha). As ampliações correspondem a 20, 32, 51, 80 e 128 vezes. As imagens foram captadas e processadas pelo sistema Vídeo Analyser 2000 code 250 (Mesdan, Itália). 


\section{- Corte Transversal}

Para o corte transversal dos fios retirados dos tecidos dos uniformes, foi necessário preparar um suporte de cartolina e utilizar resina para encapsular cada uma das fibras (junto ao suporte), de modo a deixá-las bem esticadas e centralizadas para realização do corte transversal propriamente dito, conforme demonstrado na Figura 20. Para cada fio foram preparadas quatro cápsulas.

Figura 20 - Encapsulamento dos fios têxteis: (a) Esquema do fio em cápsula de resina; (b) Esquema de corte transversal.

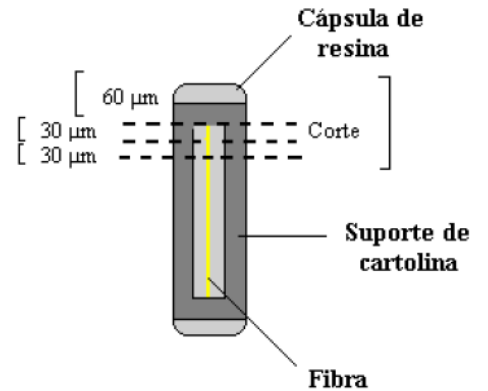

(a)

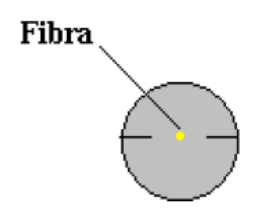

(b)

Fonte:Zonatti (2013)

\section{- Encapsulamento da Fibra}

A metodologia descrita abaixo para encapsulamento das fibras é usada rotineiramente no laboratório do Centro Tecnológico de Têxtil e Moda do Instituto de Pesquisas Tecnológicas (CETIM - IPT), do qual se apresenta o protocolo abaixo.

O seguinte processo foi adaptado da metodologia citada e realizado para preparação da secção transversal do corpo-de- prova:

- Foi marcada em cartolina recortada nas dimensões de (56x18) mm, uma sequência de oito pequenos retângulos de 7x18 mm. Essas dimensões do retângulo podem variar conforme o tamanho da cápsula. O retângulo deve ter dimensões tais que seja possível sua inserção na cápsula de gelatina;

- Vazaram-se os retângulos maiores, recortando os retângulos menores com o auxílio de uma charneira número 6. Com um estilete foi feito um pequeno corte para a fixação dos fios.

- Foram separados, por corte, os oito retângulos de 7x18 mm;

- Em cada retângulo foi montado, entre os cortes de fixação, uma amostra do fio, mantidas sob pequena tensão, no centro da parte vazada, paralelamente ao eixo maior do retângulo; 
- Para a identificação dos suportes para os corpos-de-prova necessitavam, foram recortadas uma das quatro pontas do suporte para o corpo-de-prova 1, duas pontas para o corpo-de-prova 2, três pontas para o corpo-de-prova 3 e nenhuma para o corpo-de-prova 4, nas linhas indicadas.

- Foi preparada sobre um vidro de relógio, uma pequena quantidade de solução constituída de 0,5 $\mathrm{ml}$ de base resina Technovit 7100 (Heraeus, Alemanha) e 0,5 $\mathrm{ml}$ de álcool etílico a 96\% P.A. Os corpos-de-prova foram imersos nesta solução, onde ficaram por $1 \mathrm{~h} 30 \mathrm{~min}$, para intumescer completamente;

- Nos últimos minutos do período de intumescimento, foi preparada em um béquer de $10 \mathrm{ml}$, uma segunda solução constituída de 0,0375 g do endurecedor I (pó) (reagente que acompanha a resina) e 3,75 $\mathrm{ml}$ de base Technovit 7100, misturada até dissolução completa do pó;

- Imediatamente depois de terminada a preparação da solução acima, retiraram-se os suportes da primeira solução e foram imersos nesta segunda solução, na qual deviam permanecer imersos por mais $1 \mathrm{~h} 30 \mathrm{~min}$, em temperatura ambiente;

- Retiraram-se os suportes da segunda solução, foram adicionados 0,25 ml do endurecedor II (líquido) (reagente que acompanha a resina) e se misturou até completa homogeneização.

- Esta nova solução foi vertida para dentro de uma cápsula de gelatina (Capsugel Pfizer, Cápsula Gel no 00 incolor, Brasil) e, em seguida, foi introduzido o suporte dentro da cápsula. Foi centralizado com cuidado o suporte para que as fibras ficassem perfeitamente perpendiculares à abertura da cápsula. $\mathrm{O}$ material foi deixado em repouso por no mínimo de um dia para outro (“overnight"), à temperatura ambiente;

- Após o endurecimento da resina, a cápsula de gelatina foi dissolvida (Figura) com água morna para posteriormente ser cortada, obtendo-se fatias transversais para os ensaios de microscopia.

\section{- Corte das Amostras}

Para a obtenção das secções transversais, coloca-se a cápsula de resina endurecida com a fibra no apoio do micrótomo semi-automatizado rotacional (Leica, modelo RM 2245, Alemanha) equipado com cutelo tipo "C" (Figura 21). 
Figura 21 - Micrótomo semi-automatizado rotacional (Leica, modelo RM 2245, Alemanha)

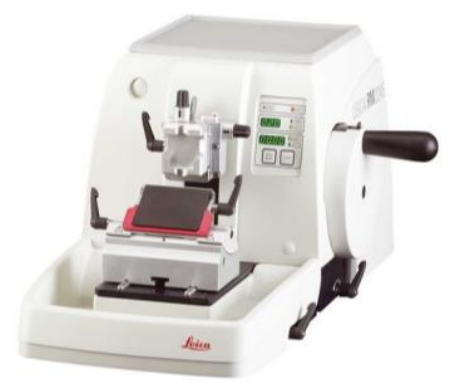

Fonte: Leica (2018)

Iniciou-se o processo de corte com espessura de $70 \mu \mathrm{m}$, para eliminar o topo, onde não há fibra e, a partir daí, com $35 \mu \mathrm{m}$ de espessura. Feitos os cortes, duas secções transversais de um mesmo corpo-de-prova foram depositadas sobre lâminas de microscopia espalmada com uma gota de óleo mineral petrolato líquido (Nujol, Mantecorp, Brasil), cobertas com lamínulas e identificadas com o número da amostra.

Os materiais foram analisados em microscópio biológico (Leica, modelo BME, Alemanha) acoplado a vídeo-câmera de captação digital de imagens (Sony, Color Video Camera ESWAVEHAD, modelo 55C-DC93-P, China). As ampliações corresponderam a 128, 320, 640, 1280 e 2016 vezes. As imagens foram captadas e processadas pelo sistema Video Analyser 2000 code 250 (Mesdan, Itália).

O diâmetro dos fios foi medido através de microscopia óptica. Na vista longitudinal, foi realizada a medição da largura do fio e no corte transversal, a medição foi feita por eixos perpendiculares e pela circunferência. A Figura 22 demonstra 0 método de cada abordagem para medição. 
Figura 22 - Métodos para medição do diâmetro de fios têxteis por microscopia óptica do fio de urdume de T1 (100\% CO). (a) medida linear na vista transversal com aumento de 128 vezes (escala $100 \mu \mathrm{m}$ ); (b) medida de raio na vista transversal com aumento de 128 vezes (escala $100 \mu \mathrm{m}$ ) e (c) medida linear na vista longitudinal com aumento de 80 vezes (escala $1 \mathrm{~mm}$ ).

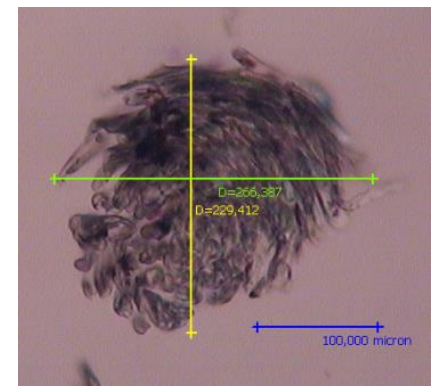

(a)

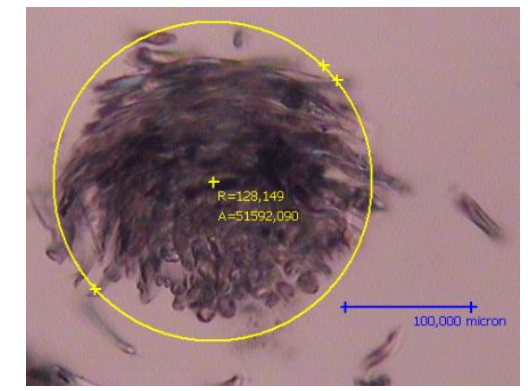

(b)

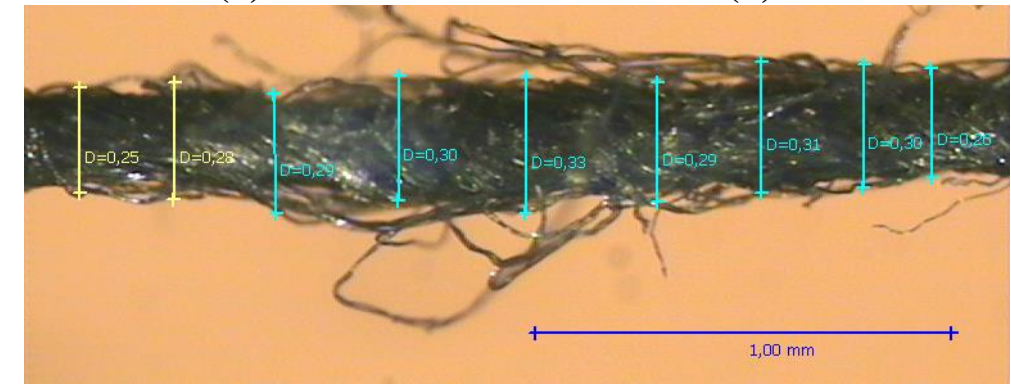

(c)

Fonte: Marcia Cristina Silva, 2018

\subsubsection{Cálculo do diâmetro dos fios com aplicação de modelo geométrico.}

As propriedades dos tecidos são regidas pelas propriedades dos fios e pelos critérios geométricos tais como seu tecimento, número de fios por polegada, grau de empacotamento do fio na estrutura e crimpagem do fio. O modelo geométrico de Pierce (Figura 23) correlaciona os fatores estruturais que controlam a construção do tecido (KASWELL, 1963).

Figura 23 - Modelo de Peirce para tecidos planos. (d) diâmetro do fio, (D) soma dos diâmetros de fios de urdume e trama, (p) espaçamento entre os fios de trama, (h) deslocamento perpendicular máximo da linha central do fio em relação ao plano do tecido, $(\theta)$ ângulo de inclinação do eixo do fio em relação ao plano do tecido, (1) comprimento do eixo do fio entre as intersecções. Os sufixos 1 e 2 representam urdume e trama, respectivamente.

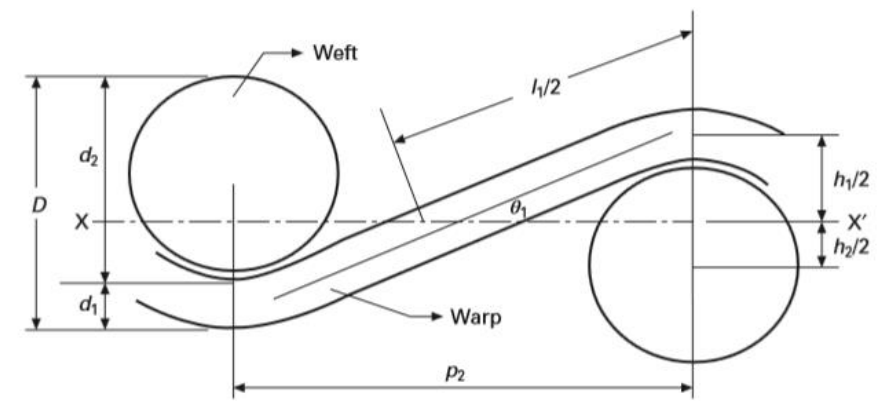

Fonte: Adaptado de KASWELL, 1963 e BEHERA, 2010 
A partir deste modelo foram estabelecidas sete equações conectando as variáveis. Nota-se que o modelo considera os fios com secção transversal circular, sem ação de compressão. Entretanto, as secções transversais dos fios apresentam formatos diferenciados, devido ao sistema de forças que atuam entre trama e urdume. Considerando-se esta hipótese (diâmetro perfeitamente circular, se aplicaria a Equação 6 para cálculo do diâmetro do fio.

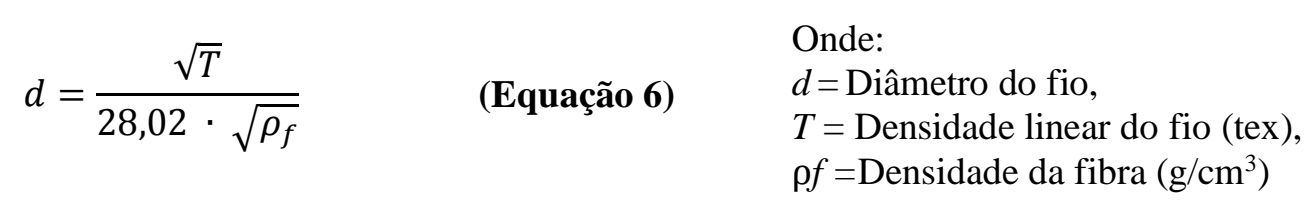

Considerando que os fios sofrem o achatamento, se faz necessária a correção pelo modelo de Peirce. O cálculo do diâmetro dos fios considerando sua densidade linear (peso por unidade de comprimento) em tex, a densidade das fibras e o fator de empacotamento dos fios seguiu a Equação 7. Conforme Behera (2010), esta equação é aplicável para muitos tipos de fios com diferentes tipos de fibras. Os valores tabelados de densidade das fibras e o fator de empacotamento do fio podem ser encontrados nas

Tabelas 5.3 e 5.4 .

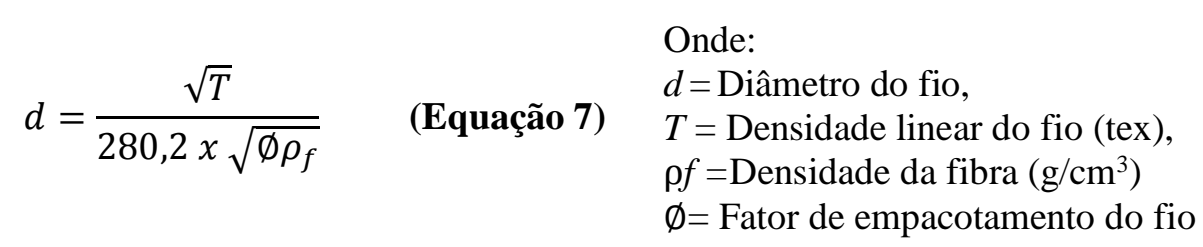

Tabela 5.3 - Densidade das Fibras $\left(\mathrm{g} / \mathrm{cm}^{3}\right)$

Fonte: Behera; Hari (2010)

\begin{tabular}{c|c}
\hline \multicolumn{1}{c}{ Fibra } & $\mathbf{P}_{\boldsymbol{F}}$ \\
\hline Algodão & 1,52 \\
Poliéster & 1,38 \\
Lã & 1,32 \\
\hline
\end{tabular}

Tabela 5.4 - Fator de empacotamento

Fonte: Behera; Hari (2010)

\begin{tabular}{l|l}
\hline Processo & $\emptyset$ \\
\hline Filatório de Anel & 0,60 \\
Open end & 0,55 \\
Fio fiado penteado & 0,60 \\
Lã fiada & 0,55 \\
Filamento contínuo & 0,65 \\
\hline
\end{tabular}

Para os fios feitos com mistura de fibras, é necessário fazer o cálculo da densidade das fibras (proporcional) de acordo com a Equação 8. 


$$
\frac{1}{\bar{\rho}}=\sum_{1}^{n} \frac{p_{i}}{p_{f t}}
$$

Onde:

$\rho=$ Média da densidade das fibras,

(Equação 8) $\quad p_{i=}$ Fração do peso do enésimo componente,

$p_{f t}=$ Densidade da fibra $\left(\mathrm{g} / \mathrm{cm}^{3}\right)$,

$\mathrm{n}=$ Número de componentes na mistura.

\subsubsection{Fator de cobertura}

Para o cálculo do fator de cobertura são necessárias a quantidade de fios de trama e urdume, densidade linear, assim como o diâmetro dos fios. Para cada conjunto de fios, o produto da contagem de fios (por polegada) e o diâmetro de fio (em polegadas) é menor que um, havendo teoricamente espaços abertos existentes entre os fios. Esta razão da superfície do tecido ocupada pelo fio em relação à superfície total do tecido é chamada de Fator de Cobertura do Tecido, cujo cálculo é demonstrado na Equação 9 (KASWELL, 1963; MALUF; KOLBE, 2003):

$$
\begin{array}{cl}
C=W \cdot d_{w}+F \cdot d_{f}-W \cdot F \cdot d_{w} \cdot d_{f} \quad \text { (Equação 9) } & \text { Onde: } \\
& \mathrm{C}=\text { fator de cobertura do tecido; } \\
\mathrm{W}=\text { número de fios de urdume por polegada; } \\
\mathrm{F}=\text { número de fios de trama por polegada; } \\
\\
\mathrm{d}_{\mathrm{w}}=\text { diâmetro do fio de urdume (em polegadas); } \\
\mathrm{d}_{\mathrm{f}}=\text { diâmetro do fio de trama (em polegadas) }
\end{array}
$$

\subsubsection{Ensaio de Inflamabilidade na Universidade do Minho - Portugal}

A primeira aproximação com os ensaios de inflamabilidade foi realizada de acordo com a Norma NF G07-182 - Textiles - Comportement au feu - Détermination des propriétés de propagation de flamme sur éprouvettes orientées à 45 degrés - Mesurage de la vitesse de propagation de flamme (ASSOCIATION FRANÇAISE DE NORMALISATION - AFNOR, 1985). O método proporciona a medição da velocidade de propagação da chama de acordo com a Equação 10.

$$
V=\frac{E}{t} \quad \text { (Equação 10) } \begin{aligned}
& \begin{array}{l}
\text { Onde: } \\
\mathrm{E}=\text { Velocidade de queima do material têxtil }(\mathrm{cm} / \mathrm{s}) ; \\
\mathrm{t}=\text { Tempo de queima entre os marcadores }(\mathrm{s})
\end{array}
\end{aligned}
$$

A cabine utilizada pertence ao Departamento de Engenharia Têxtil, Laboratório de Ensino, da Universidade do Minho, Portugal, a qual será chamada neste estudo de “Cabine UMINHO”, mostrada na Figura 24. 
Figura 24 - Cabine de teste de inflamabilidade ("Cabine UMINHO") conforme Norma NF G07-182:1985. Posição do corpo-de-prova a 45.

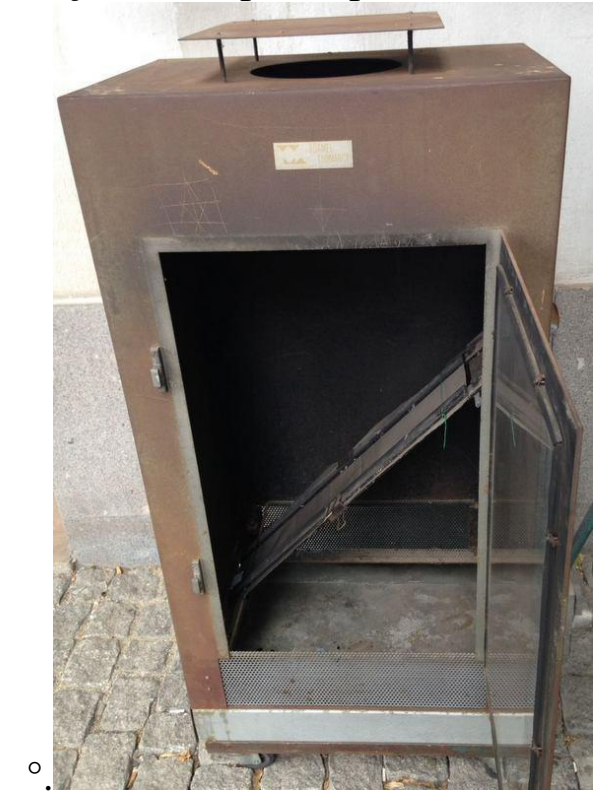

Fonte: Marcia Cristina Silva, 2017

Os corpos-de-prova foram preparados nas dimensões de 160x600 mm com os tecidos adquiridos do fornecedor de material para confecções de uniformes profissionais, Tecidos Vinatex Ltda, na cidade de São Paulo. A norma estabelece a preparação e ensaio de três corpos-de-prova, porém foram preparados dez no sentido da trama e dez no sentido do urdume dos tecidos T1 (sarja 100\% algodão), T2 (tela, 67\% poliéster e 33\% algodão) e T3 (tela 100\% poliéster). Foram submetidos ao ensaio, com o objetivo de gerar dados para comparação e validação do protótipo de cabine para teste de inflamabilidade programável desenvolvida para as atividades de ensaio de pequenas amostras, as quais caracterizam este estudo.

Não foi possível realizar este teste nos tecidos retirados dos uniformes, já que as amostras de tecidos que se podem extrair desses uniformes são de dimensões inferiores às estipuladas na norma citada.

Os corpos de prova foram acondicionados em sala climatizada com temperatura $20^{\circ} \mathrm{C}$ e umidade relativa do ar de $65 \%$ por 48 horas. A cabine foi posicionada na área externa do edifício do Departamento de Engenharia Têxtil da Universidade do Minho, Cidade de Guimarães, Portugal. O material foi retirado da sala climatizada e acondicionado em saco plástico, até a realização do ensaio.

Os testes foram realizados no período das 9:00 as 19:00 horas do dia 20 de junho de 2017 , com a temperatura acima de $30^{\circ} \mathrm{C}$ e umidade relativa abaixo de $40 \%$ (WORLD 
WEATHER, 2017). Na preparação para o teste, cada amostra foi fixada no quadro e colocada na cabine com a inclinação de $45^{\circ}$. No quadro que serve de suporte para o teste existem duas molas localizadas a uma distância de $500 \mathrm{~mm}$. As molas são fixadas com um fio, o qual tem a função de gatilho sonoro para acionamento do cronômetro manualmente. Para o início do fogo foi utilizado um isqueiro comum para acender um pavio feito de tecido misto, $67 \%$ poliéster e $33 \%$ algodão e foi fixado com grampos metálicos na base dos corpos de prova, ilustrado na Figura 25. Ao final de cada ensaio, o tempo de queima foi registrado.

Figura 25 - Montagem do corpo de prova no quadro. As linhas verdes marcam o comprimento queimado.

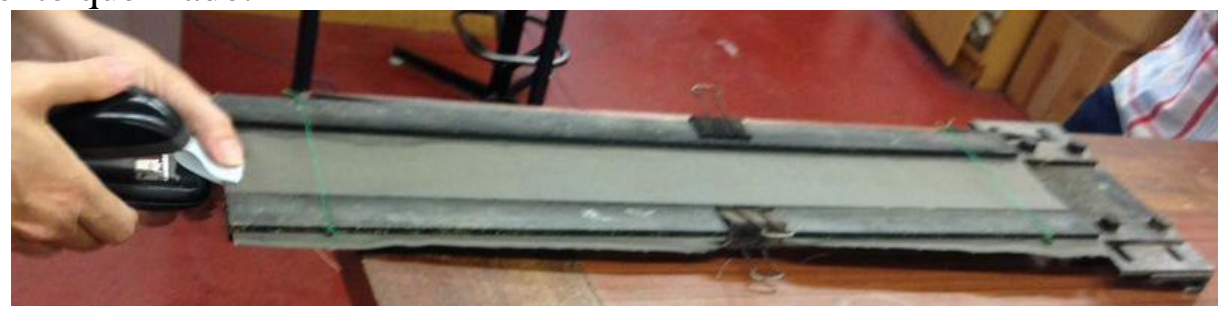

Fonte: Marcia Cristina Silva, 2017

\subsubsection{Ensaio de Inflamabilidade na Universidade de São Paulo- USP}

Os ensaios de inflamabilidade nas amostras retiradas das peças de uniforme foram realizados em equipamento protótipo desenvolvido para atender as especificidades deste projeto, com maior flexibilidade na caracterização física de materiais têxteis disponível em pequenas dimensões. Esta cabine protótipo será chamada neste estudo de "Cabine USP”. O equipamento conta com a utilização de dispositivo de ignição intercambiável e um CLP (controlador lógico programável) para determinação da rotina de ensaio e cronômetro acionados por sensores.

Esse protótipo de Cabine de Teste de inflamabilidade foi construído com as adaptações necessárias aos objetivos deste estudo e das premissas estabelecidas nas normas 16CFR Part 1610:2018 - Standard for flammability of clothing textile; ISO 6940:2004 - Textile Fabrics - Burning behaviour - Determination of ease of ignition of vertically oriented specimens; ISO 6941:2003 - Textile Fabrics - Burning behaviour Measument of flame spread properties of vertically oriented specimens e NF G07-182 Textiles - Comportement au feu - Détermination des propriétés de propagation de flamme sur éprouvettes orientées à 45 degrés - Mesurage de la vitesse de propagation de flamme. O protótipo pode ser observado na Figura 26. 
Figura 26 - Cabine USP para teste de inflamabilidade

Fonte: Marcia Cristina Silva, 2017

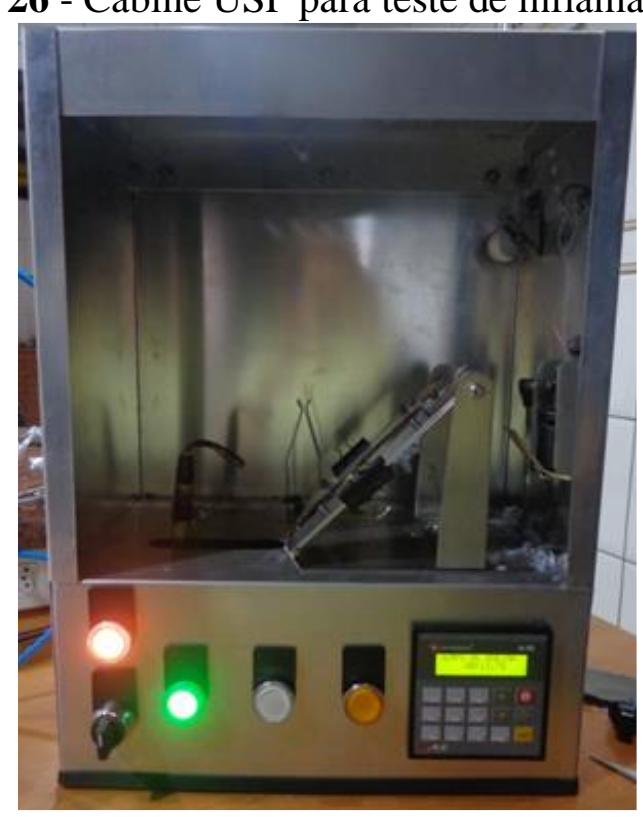

Para comparação com os ensaios realizados em Portugal na Cabine UMINHO e validação da Cabine USP, uma série de testes com dez amostras foi realizado com os tecidos T1 e T2, sentido de trama e urdume, sendo possível estabelecer o valor de velocidade de queima, calculado pela Equação 10 e proceder os ajustes desse ensaio.

Os parâmetros utilizados para os testes foram: dez corpos-de-prova de dimensão de 150 x 50mm; tempo de chama no tecido, 3 segundos; gás utilizado propano, espaço percorrido pela chama de $135 \mathrm{~mm}$.

\subsubsection{Análise do sistema de medição da Cabine USP.}

A Cabine USP foi submetida a uma análise de seu sistema de medição para dimensionamento dos erros de medição. Cada característica medida carrega um erro de medição, de modo que a variabilidade total observada pode ser dividida em duas: (i) variabilidade real da amostra (causas aleatórias, inerentes ao processo produtivo) e (ii) a variabilidade inerente à medição. A variância do erro de medição é composta por dois elementos, conforme descrito na Equação 11, a repetibilidade e a reprodutibilidade (MONTGOMERY, 2009).

A repetibilidade é a variação inerente ao equipamento, tratando-se de variação de causa comum (erro aleatório) decorrente de sucessivas medições feitas sob condições definidas. Também sinaliza o grau de concordância entre resultados de medições sucessivas de um mesmo objeto sob as mesmas condições. A repetibilidade (Equação 12) é conhecida como variação dentro do sistema. 
A reprodutibilidade (Equação 13) é definida como a variação das médias das medições feitas por diferentes avaliadores, utilizando o mesmo instrumento, na medição da mesma característica, sob as mesmas condições ambientais. Representa a variação das médias entre sistemas ou entre condições de medição e não se aplica a sistemas automatizados (MONTGOMERY, 2009).

$$
\begin{aligned}
& \sigma_{\text {med }}^{2}=\sigma_{\text {repe }}^{2}+\sigma_{\text {repro }}^{2} \\
& \text { (Equação 11) } \\
& \text { Onde: } \\
& \bar{R}=\text { média das amplitude } \\
& R \overline{\bar{x}}=\text { média das médias das amplitudes } \\
& d_{2}=\text { tabelado em função de } n \text {. } \\
& \sigma_{\text {repe }}^{2}=\frac{\bar{R}}{d_{2}} \\
& \text { (Equação 12) } \\
& \text { Onde: } \\
& \bar{R}=\text { média das amplitude } \\
& R \overline{\bar{x}}=\text { média das médias das amplitudes } \\
& d_{2}=\text { tabelado em função de } n \text {. } \\
& \sigma_{\text {repro }}^{2} \\
& =\sqrt{\left(\frac{R_{\bar{X}}}{d_{2}}\right)^{2}-\frac{\left(\sigma_{\text {repe }}\right)^{2}}{n}}
\end{aligned}
$$

No caso da Cabine USP a ação é automatizada, sendo o ensaio destrutivo e realizado pelo mesmo operador. Para trabalhar com tais condições, uma vez que a peça não pode ser reavaliada, diversas peças semelhantes (homogêneas) foram escolhidas para o estudo e foi feita a suposição de que as peças são idênticas (ou similares) (WERKEMA, 2002).

Neste estudo, os conjuntos de peças homogêneas foram denominados lotes e foram ensaiados oito lotes com três amostra cada do tecido T1, totalizando 24 amostras, as quais foram submetidas ao ensaio de velocidade de queima da Cabine USP, sendo quatro lotes (12 amostras no total) em duas ocasiões diferentes. As velocidades de queima foram calculadas pela Equação 10.

Existem dois métodos para a avaliação do sistema de medição, a saber, o método da Média e Amplitude a qual fornece uma estimativa da repetibilidade e da reprodutibilidade, sem a interação de um sobre o outro, porém não identifica a diferença entre os avaliadores. Já o método da ANOVA decompõe a variação em operador, peça, interação operador-peça e equipamento. A estimativa da capacidade do sistema de 
medição pode ser quantificada pelo índice R\&R, calculado pela Equação 14 (MONTGOMERY, 2009).

$$
R \& R=6 \sigma_{\text {med }}=6 \sqrt{\sigma_{\text {repe }}^{2}+\sigma_{\text {repro }}^{2}}
$$

Uma regra geral de aceitação é apresentada no Manual de Análise do Sistema de Medição do Quality System Requirements (QS-9000), normativa para o sistema de qualidade das indústrias automotivas.(i) Erro menor que 10\% - sistema de medição aceitável; (ii) Erro entre 10\% e 30\% - o sistema pode ser aceito com base na importância de sua aplicação, no custo do aparato de medição e nos seus custos de reparo e (iii) Erro acima de 30\% - sistema de medição inadequado necessita de melhorias (WERKEMA, 2002).

\subsubsection{Determinação da velocidade de queima dos tecidos dos uniformes dos aeronautas}

Para os tecidos retirados dos uniformes dos aeronautas P1 a P8, vinte corpos de prova foram preparados nas dimensões de 55 por $155 \mathrm{~mm}$. Na preparação para o teste, cada amostra foi fixada no quadro e colocada na cabine com a inclinação de $45^{\circ}$. $\mathrm{O}$ tamanho da chama foi ajustado em $16 \mathrm{~mm}$ foi aplicada na superfície do tecido, próxima à borda inferior por três segundos e sem exaustão forçada e o gás utilizado foi o propano. A chama percorreu o comprimento do tecido por $135 \mathrm{~mm}$ até o limite marcado com a linha de suporte do pêndulo que ao se romper aciona o sensor e encerra a contagem do tempo no cronômetro.

Como pré-teste o mesmo ensaio descrito foi realizado com amostras dos tecidos T1 e T2. O ensaio de velocidade de queima foi realizado a partir da adaptação da norma CFR 1610, a qual estabelece três classes de inflamabilidade para os tecidos (vide item 4.8). As mudanças foram efetuadas para priorizar o tempo de queima de cada material em um comprimento pré-estabelecido, possibilitando o cálculo da velocidade de queima do material têxtil retirado dos uniformes, de acordo com a Equação 10.

\subsubsection{Digital Scanning Calorimetry (DSC):}

De maneira a tentar obter informações suplementares sobre o comportamento térmico dos materiais dos tecidos, foram retiradas amostras de $2 \mathrm{~cm}^{2}$ dos tecidos comerciais T1 100\% algodão) e T2 (67\% Poliéster e 33\% Algodão). Este ensaio foi 
realizado com as amostras em temperatura ambiente, em equipamento Mettler Star SW 8.10 USA, com faixa de temperatura de ensaio de $0^{\circ} \mathrm{C}$ a $450^{\circ} \mathrm{C}$, com velocidade de aquecimento de $10^{\circ} \mathrm{C} / \mathrm{min}$.

\subsubsection{Simultaneous Thermogravimetric analysis (STA)}

De maneira a tentar obter informações suplementares sobre o comportamento térmico dos materiais dos tecidos, foram retiradas amostras de $2 \mathrm{~cm}^{2}$ dos tecidos comerciais T1 100\% algodão) e T2 (67\% Poliéster e 33\% Algodão). Deve-se esperar até que a amostra degrade por completo e, na medida em que o ensaio é realizado, o software do aparelho vai gerando o gráfico com as características da amostra. O ensaio foi realizado em equipamento STA 7000 (Hitachi) (Figura 5.14), com atmosfera de nitrogênio e faixa de temperatura de ensaio de $30^{\circ} \mathrm{C}$ a $600^{\circ} \mathrm{C}$ e com $10^{\circ} \mathrm{C} / \mathrm{min}$ de velocidade de aquecimento.

Figura 27 - Aparelho STA 7000

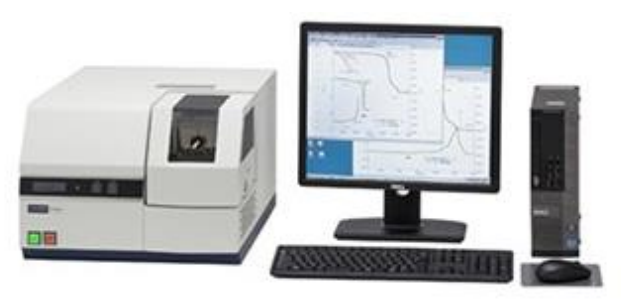

Fonte: (HITACHI, 2017)

\subsubsection{Testes Estatísticos}

\subsubsection{Cálculo de média, desvio-padrão e coeficiente de variação}

Para determinar as diferenças entre a velocidade de propagação de chamas das amostras de tecidos dos uniformes de comissários, o trabalho foi realizado comparando as médias de 10 amostras independentes extraídas de oito peças de uniforme.

Os dados são apresentados como média (Equação 15) \pm desvio padrão (Equação 16) (C.V.\%) (Equação 17).

$$
\begin{array}{r}
\bar{x}=\frac{\sum x}{n} \\
s=\sqrt{\frac{\sum(x-\bar{x})^{2}}{n-1}} \\
C V(\%)=\frac{s}{\bar{x}} 100
\end{array}
$$


Onde: "n" representa o número de amostras em cada teste e " $x$ ", o valor de cada valor determinado no teste.

\subsubsection{Análise dos Dados}

A abordagem de análise multivariada será utilizada por sua característica de usar várias técnicas estatísticas simultaneamente para construção de conhecimento e tomada de decisão utilizando todas as variáveis na interpretação teórica do conjunto de dados obtidos (HAIR, 2010; MOITA NETO, 2004; RODRIGUES; PAULO, 2011). Para identificar a melhor abordagem da Análise Multivariada e alcançar os melhores resultados, iniciam-se com os três julgamentos que devem ser feitos sobre o objetivo da pesquisa e natureza dos dados (HAIR, 2010):

1. As variáveis podem ser divididas em independentes e dependentes com base em alguma teoria?

Na teoria da inflamabilidade têxtil, a tempo de chama dependente das variáveis tais como os tipos de fibra, ligamento, fator de cobertura, gramatura e espessura.

2. Em caso positivo, quantas variáveis são tratadas como dependentes em uma análise simples?

A variável dependente é o tempo de chama.

3. Como as variáveis, independentes e dependentes são mensuradas?

A variável dependente tempo de queima é numérica, caracterizando-se por variável quantitativa contínua. As variáveis independentes fibra e ligamento são não numéricas, caracterizando-se como variáveis qualitativas nominais $\mathrm{e}$ gramatura e espessura são variáveis numéricas, caracterizando-se como variável quantitativa contínua (RODRIGUES; PAULO, 2011).

De acordo com Hair (2010), para uma relação de dependência com umas variáveis dependentes numéricas e múltiplas variáveis não numéricas, as melhores técnicas estatísticas serão a Análise de Variância e a Regressão Múltipla.

\subsubsection{Análise de variância (ANOVA) e Regressão Múltipla}

Permite explorar simultaneamente a relação entre diversas variáveis independentes com uma variável dependente métrica e analisar a variância entre os tratamentos. A análise de variância (ANOVA) baseia-se na decomposição da variação total da variável resposta em partes que podem ser atribuídas ao tratamento (variância entre) e ao erro experimental (variância dentro)(ANJOS et al., 2009).

A Regressão Múltipla analisa a relação de dependência de uma variável e outras variáveis independentes, criando condições para descrever, através de um modelo matemático a relação entre as variáveis (Equação 18). O principal objetivo para este 
projeto é estabelecer a relação causal entre as variáveis e estimar os valores das variáveis dependentes (RODRIGUES; PAULO, 2011).

$$
\begin{gathered}
Y_{i j}=\mu+\tau_{i}+\epsilon_{i j} \\
\mathrm{i}=1, \ldots, \mathrm{I} \quad \mathrm{J}=1, \ldots, \mathrm{J}
\end{gathered}
$$

Onde:

$Y_{\mathrm{ij}}$ é a observação do i-ésimo tratamento na j-ésima unidade experimental ou parcela; $\mu$ é o efeito constante (média geral); $\tau_{i}$ é o efeito do i-ésimo tratamento; $\varepsilon_{\mathrm{ij}}$ é o erro associado ao i-ésimo tratamento na j-ésima unidade experimental

\subsubsection{Análise dos dos resíduos}

A ANOVA assume que as observações são idependentes e normalmente distribuídas com a mesma variância para cada tratamento.

Para verificação da normalidade dos resíduos, foram conduzidos os seguintes testes com os resíduos (MINITAB INC., 2000):

- Teste de Anderson-Darling

- Este teste compara a função de distribuição cumulativa empírica de seus dados de amostra com a distribuição esperada se os dados estiverem normais. Se esta diferença observada for suficientemente grande, o teste rejeitará a hipótese nula de normalidade da população

- Teste de normalidade de Kolmogorov-Smirnov.

- Este teste observa a máxima diferença absoluta entre a função de distribuição acumulada assumida para os dados, no caso a Normal, e a função de distribuição empírica dos dados. Se esta diferença observada for suficientemente grande, o teste rejeitará a hipótese nula de normalidade da população. Se o valor p desses testes for menor que o nível escolhido, você pode rejeitar sua hipótese nula e concluir que a população não é normal

Para a verificação da igualdade de variância dos resíduos, além da análise gráfica, buscando a sobreposição das variâncias, os seguintes teste foram conduzidos (ESTATCAMP - CONSULTORIA ESTATÍSTICA; DIGUP - DESENVOLVIMENTO DE SISTEMAS E CONSULTORIA ESTATÍSTICA, 2018):

- Teste de Bartlet

- A estatística de teste de Bartlett calcula a média aritmética ponderada e a média geométrica ponderada de cada variância da amostra com base nos graus de liberdade. Quanto maior a diferença nas médias, maior é a probabilidade de variâncias das amostras não serem iguais. O teste segue uma distribuição $\chi^{2}$ com $\mathrm{k}-1$ graus de liberdade. Se o valor de $\mathrm{p}$ for 
menor do que o de seu nível de $\alpha$, rejeite a hipótese nula de que as variâncias são iguais.

- O teste de Bartlett é sensível em relação a hipótese de normalidade dos dados. Se rejeitarmos a hipótese de normalidade, é melhor utilizarmos o teste proposto por Levene. Porém, se a hipótese de normalidade não for violada, o teste proposto por Bartlett tem um comportamento melhor que o teste proposto por Levene.

- Teste de Levene

- O método de cálculo para o teste de Levene é uma modificação do procedimento de Levene (Levene, 1960) que foi desenvolvido por Brown e Forsythe (1974). Esse método considera as distâncias das observações da mediana da amostra em vez da média da amostra. O uso da mediana da amostra, em vez da média da amostra, torna o teste mais robusto para amostras de menor dimensão e torna o procedimento assintoticamente livre de distribuição. Se o valor de $\mathrm{p}$ for menor do que o de seu nível de $\alpha$, rejeite a hipótese nula de que as variâncias são iguais. O teste de Levene é indicado como alternativa ao teste de Bartlett, quando a distribuição dos resíduos se afastar consideralvemente da normalidade (RIBOLDI et al., 2014)

- Teste de Bonett

○ O método de Bonett é normalmente mais poderoso, quando as amostras possuírem mais de vinte observações cada.

\subsubsection{Método de comparação múltipla de Hsu}

O método foi criado para identificar níveis de fator que são o melhor, insignificantemente diferentes do melhor e aqueles que são significativamente diferentes do melhor. Você pode definir "melhor" como a média mais alta ou a média mais baixa. Este procedimento é normalmente usado após uma ANOVA para analisar mais precisamente as diferenças entre médias de níveis. O método de Hsu cria um intervalo de confiança para a diferença entre a média de cada nível e o melhor das outras médias do nível. Se um intervalo possui zero como ponto extremo, existe uma diferença estatisticamente significante entre as médias correspondentes (MINITAB INC., 2000). 


\subsubsection{Inferência estatística}

Para se estudar as generalizações sobre uma população, que neste caso são os tecidos utilizados na confecção de uniformes de comissários de bordo, torna-se necessário o uso de um conjunto de procedimentos nas amostras extraídas para a realização de uma inferência estatística. Dentre estas técnicas estão a determinação do número de observações, o esquema de seleção das unidades, o cálculo das medidas estatísticas, a determinação da confiança nas estimativas, a significância dos testes estatísticos entre outros (MAGALHÃES; LIMA, 2015).

\subsubsection{Teste de Hipóteses}

Uma hipótese estatística é uma suposição acerca da distribuição de uma variável aleatória, também definida como uma proposição sobre uma característica de uma população encontrada em ensaio experimental proveniente de uma amostra, examinada para prover evidências a favor ou contra a hipótese testada, sendo passível de aceitação ou negação. Ela só pode ser aceita depois de cientificamente testada. Para tomada de uma decisão, teste de hipóteses baseia-se em cálculos estatísticos para concluir se um valor é válido ou não no fenômeno estudado, refletindo o comportamento da população (LOPES, Luis Felipe Dias et al., 2005).

São estabelecidas duas hipóteses, a hipótese nula onde não existe diferença significativa entre as amostras e a hipótese nula, que prova a diferença entre as amostras. Tratando-se de evidências experimentais, estão sujeitas a erros amostrais e não amostrais. Por causa das flutuações amostrais, ao comparar duas hipóteses e tomar uma decisão, pode-se tomar a decisão errada. São dois tipos de erro: i) Erro Tipo I ( $\alpha$ ): Rejeitar a hipótese nula quando na realidade ela é verdadeira e o ii) Erro Tipo II ( $\beta$ ): Não rejeitar a hipótese nula quando na realidade ela é falsa (ANTONISAMY; CHRISTOPHER; SAMUEL, 2010).

Neste estudo, para um erro tipo I, com $a=5 \%$, os valores de $p(p$-value) menor que 0,05 foram considerados estatisticamente significantes para a aceitação da hipótese nula. Antes de testar a diferença entre os grupos, o teste de normalidade para a distribuição dos dados e a homogeneidade das variâncias foi verificado. Para comparação de médias entre dois grupos de dados numéricos e contínuos, foi utilizado o teste t de Student e para a comparação de mais de dois grupos foi utilizado a ANOVA. 


\subsubsection{Teste $F$}

$\mathrm{O}$ teste $\mathrm{F}$ compara as variâncias de duas populações. A estatística de $\mathrm{F}$ tem a distribuição de F de Fisher-Snedecor com k-1 e n-k graus de liberdade onde k= número de grupos e n=número de observações. Quando o valor de $\mathrm{F}$ for maior que o $\mathrm{F}$ tabelado pode-se considerar o fator significante para o modelo (ANTONISAMY; CHRISTOPHER; SAMUEL, 2010).

\subsubsection{Teste não paramétrico de Kruskal- Wallis}

O teste de Kruskal-Wallis é o análogo ao teste $\mathrm{F}$ utilizado na ANOVA 1 fator. Na análise de variância depende da hipótese de que todas as populações em confronto são independentes e normalmente distribuídas, o teste de Kruskal-Wallis não coloca nenhuma restrição sobre a comparação (MINITAB INC., 2000).

\subsubsection{Coeficiente de Correlação de Pearson}

O coeficiente de Pearson é uma medida de associação linear entre as variáveis, as quais guardam semelhanças na distribuição de seus escores. Podem se associar a partir da distribuição das frequências ou compartilhamento de variâncias (MINITAB INC., 2000). Os valores dos coeficientes de correlação estão descritos na Tabela 5.5.

Tabela 5.5 - Fator de correlação de Pearson como medida de associação linear entre as variáveis.

\begin{tabular}{lll}
\hline Coeficiente & Intensidade da correlação \\
\hline 0,10 até 0,30 & Fraco \\
0,40 até 0,60 & Moderado \\
0,70 até 1,00 & Forte \\
\hline Fonte: Adaptado Dancey; Reidy (2006) &
\end{tabular}

\subsubsection{Software}

Estes dados foram analisados estatisticamente usando o software Minitab (Minitab Inc. versão 18 - 2017), disponível para alunos de pós-graduação no Sistema de Download de Software Institucional da Superintendência de Tecnologia da Informação da USP.

Para análise dos dados, inicialmente foi empregada a função "Estat $\rightarrow$ ANOVA $\rightarrow$ Um fator" com nível de significância de 5\% bilateral, na qual a resposta é representada pelos valores de "velocidade de queima" e o fator por todas as demais variáveis determinadas neste estudo (número de fios de trama; número de fios de urdume; fator de cobertura; torção; gramatura; espessura; diâmetro do fio; densidade linear; ligamento; composição; direção trama ou urdume). 


\section{RESULTADOS E DISCUSSÃO}

\subsection{AUSÊNCIA DE RESPOSTA DAS LINHAS AÉREAS}

O estabelecimento de contato institucional com as empresas aéreas que atuam no Brasil demonstrou-se difícil e os canais de comunicação não receptivos para este tipo de abordagem. As tentativas ocorreram nos meses de agosto e setembro de 2016, quando foi solicitado por meio do canal virtual disponível no site de cada Linha Aérea, a oportunidade de expor o estudo sobre os uniformes em uma reunião, conhecer o processo de desenvolvimento dos uniformes e escolha dos materiais têxteis e também solicitar uma amostra do uniforme. Durante o processo, foi enviada uma carta institucional para uma das companhias, mais especificamente para o seu setor de Gestão de Resíduos, porém desde outubro de 2016 e após diversos telefonemas pedindo informações não se obteve resposta. Novas tentativas de contato foram realizadas por correspondência eletrônica em novembro de 2017 e abril de 2018 sem que fossem respondidas.

Foram realizadas várias tentativas por contato telefônico e correio eletrônico para as Linhas Aéreas, todas resultando infrutíferas, posto que não houve respostas.

\subsection{ENTREVISTAS.}

Realizou-se entrevista com a empresa $\operatorname{Retalhar}^{1}$ em 18 de novembro de 2016 que trabalha com a destinação final dos uniformes usados pelos aeronautas no Brasil.

Em adição foi realizada em 26 de janeiro de 2017 uma entrevista com Prof. Dr. Donizete de Andrade do Instituto Tecnológico de Aeronáutica para a abordagem da probabilidade de um acidente semelhante ao proposto neste estudo acontecer.

\section{Síntese da Entrevista com Lucas Corvacho da Empresa Retalhar.}

O relato do Sr. Lucas Corvacho em todo o momento preservou o sigilo de informações de seus clientes, sendo a sua abordagem a mais genérica possível em relação às Linhas Aéreas atendidas.

A destinação dos uniformes utilizados pelos funcionários das Linhas Aéreas difere de outras organizações e a imagem institucional representada pelo uniforme é protegida de uso indevido. Ele esclareceu que o fluxo de processos exigido pelas Linhas Aéreas atendidas pela "Retalhar" demanda soluções para a gestão do descarte de seus uniformes usados. Quando as peças chegam a "Retalhar", todas as referências que indicam a Linha Aérea a qual o uniforme representa são retiradas e inutilizadas. Os

\footnotetext{
${ }^{1}$ www.retalhar.com.br
} 
uniformes seguem para dois processos distintos: a total descaracterização dos uniformes pelo desfibramento ou a reutilização dos tecidos dos uniformes na confecção de produtos promocionais.

As peças desfibradas seguem para a produção de nãotecido destino à fabricação de cobertores ou mantas para revestimento têxtil, que podem ser vendidos no mercado sem restrição. Já a produção de itens promocionais é totalmente devolvida à Linha Aérea que fará a distribuição de acordo com as suas agendas de compromissos.

Observados os cuidados e condições impostos para a destinação dos uniformes usados, foi possível entender o sigilo requerido pela Linha Aérea nas rotinas de uso de seus uniformes e também a segurança ambiental dispensada no descarte dos uniformes usados.

\section{Síntese da Entrevista com Prof. Dr. Donizeti de Andrade do ITA.}

Algumas informações necessárias para dimensionar a probabilidade de um acidente semelhante acontecer, foram obtidas pela entrevista com o Prof. Dr. Donizete do ITA. De acordo com ele, a ocorrência de eventos com fogo a bordo na aviação civil envolvendo os aeronautas é raro e por este motivo é pouco relatado na literatura acadêmica.

Em suas palavras, confirma a excepcionalidade deste tipo de evento, sendo a causa pela qual ainda não foi levado em pauta como prioridade de segurança na aviação. Nos últimos 60 anos, várias ações foram realizadas para melhorar a segurança de voo, as quais previnem falhas antes que haja a eventualidade de que um uniforme possa ser queimado. Considerando o Global Accident Rate (número de acidentes/ milhão de voos), pode-se considerar que esse tipo de acidente é muito raro.

Dessa forma, o melhor direcionamento seria a sensibilização das pessoas envolvidas no processo, entre elas, o fabricante das aeronaves, os operadores das Linhas Aéreas e as autoridades aeronáuticas. Também cabe a exploração das questões de segurança de voo através da integridade do produto e integridade das operações, os quais representam os dois pilares de segurança segundo o FAA (Federal Aviation Administration).

\subsection{VISITA TÉCNICA AO CITEVE - FAMALICÃO, PORTUGAL.}

Para obter mais conhecimento sobre os testes de inflamabilidade, no dia 19 de junho de 2017 foi realizada a visita técnica ao laboratório de Física Têxtil do CITEVE 
localizada na cidade de Vila Nova de Famalicão. A visita foi conduzida pela Engenheira Suzana Blattman, apresentando os equipamentos e os testes realizados com objetivo de certificação de produtos inclusive as normativas ABNT NBR ISO 15025: 2016 Vestimentas de Proteção contra calor e chamas - Método de ensaio para a propagação limitada de chamas e 16CFR Part 1610 - Standards for the flammability of clothing textile, assim como outras instalações e equipamentos desse renomado centro.

Ao ser questionada sobre realizar o teste de inflamabilidade em peças já usadas, com relação a: (i) correlação entre as características físicas dos tecidos dos uniformes e a velocidade de queima; e (ii) a proporcionalidade da velocidade de queima das duas cabines (Cabine UMINHO e Cabine USP) a Engenheira Suzana sinalizou possível dificuldade em replicar os testes devido ao eventual desgaste das peças.

Foram mostrados os equipamentos de teste de chamas que atendem a mais de quinze normativas atualmente em vigência, inclusive com uma cabine para atender várias normas com as suas especificidades de tamanhos de amostras. O gás utilizado no Laboratório é o butano e foi sugerido o uso do mesmo gás no protótipo que estava sendo desenvolvido na época (Cabine USP). Sobre a exaustão da cabine, alertou que não há alteração significativa nos resultados do teste e que a velocidade do ar de exaustão não pode passar de $0,2 \mathrm{~m} / \mathrm{s}$.

\subsection{CARACTERIZAÇÃO DOS UNIFORMES DOS AERONAUTAS.}

Foram obtidas de uma confecção (a qual solicitou sigilo de sua identidade e das Linhas Aéreas para as quais trabalhava) a qual já trabalhou nos anos 1990 com produção de uniformes de aeronautas, duas camisas femininas distintas e uma masculina de serviço (todas já confeccionadas) e amostra do tecido de uma das camisas femininas. A Linha Aérea de origem desse material será designada pela letra "A".

Por meio de doação particular de um aeronauta aposentado (o qual solicitou sigilo de sua identidade e da Linha Aérea na qual operava), foi obtido o conjunto completo de uniforme constituído de: duas camisas, dois paletós e uma calça. A Linha Aérea de origem desse material será designada pela letra "B".

\subsubsection{Registro Fotográfico}

As características visuais dos uniformes de aeronautas estão apresentadas a seguir nas Figuras 28 e 29 e Tabelas 6.1 e 6.2 e serão brevemente discutidas nesta parte inicial. 
Análises mais detalhadas serão apresentadas quando necessário para relacionar tais características com a velocidade de queima do material têxtil.

Cada peça recebida esse estudo, foi fotografada para ilustrar a respectiva ficha de identificação (Apêndice A) objetivando o controle dos materiais após a desmontagem da peça. Observa-se que as cores empregadas nos uniformes são relacionadas à identidade visual da Linha Aérea. Como em todos os casos se deve preservar o sigilo da identidade das Linhas Aéreas, as peças foram fotografadas em preto e branco.

As camisas da Linha Aérea A estão ilustradas na Figura 28. Nesta etapa, foi possível observar os métodos de confecção utilizados para a produção das peças.

Figura 28 - Peças de Uniforme da Linha Aérea A. (a) Peça P1 - Camisa feminina com pregas, (b) peça P2 - Camisa Feminina Xadrez, (c) Peça P3 - Camisa Masculina de Serviço. Indicação de escala de $10 \mathrm{~cm}$

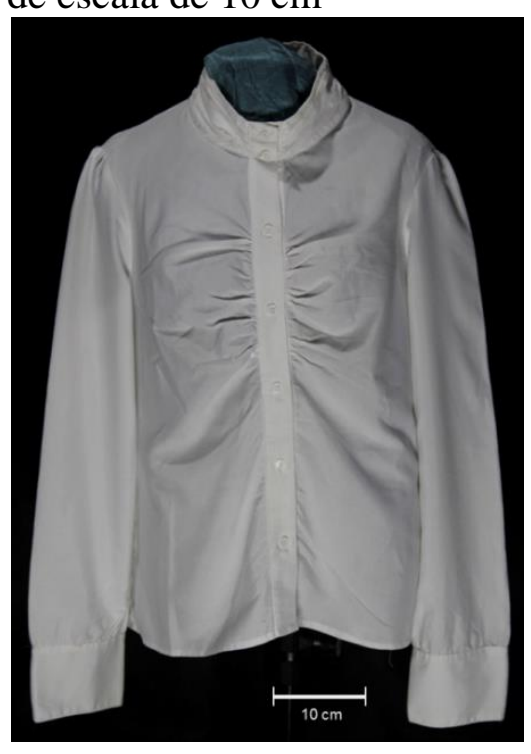

(a)

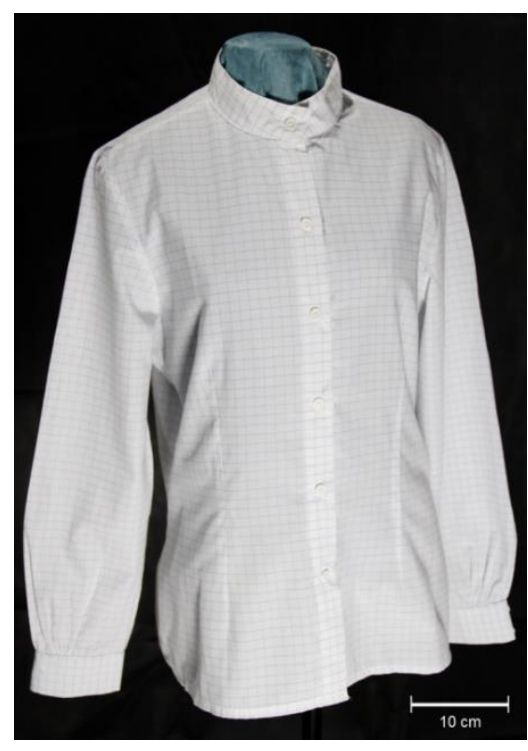

(b)

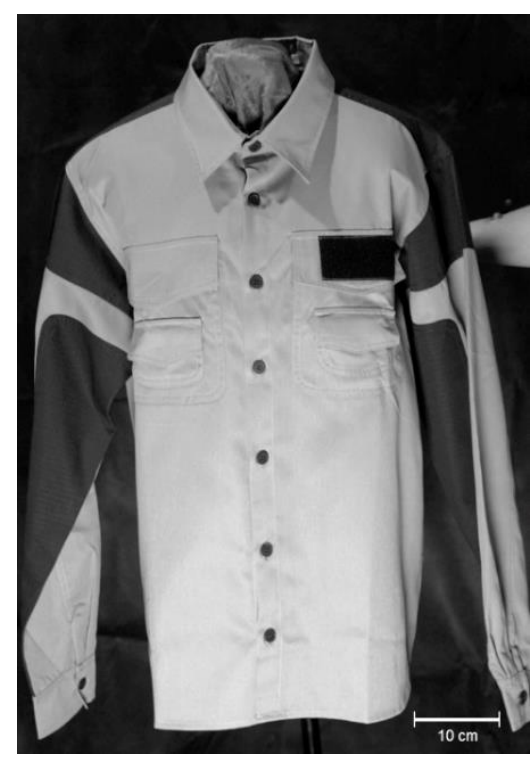

(c)

Fonte: Marcia Cristina Silva, 2017

Nota-se que os uniformes da Linha Aérea B (Figura 29) são mais elaborados, pois são peças de alfaiataria, inclusive com forro nos paletós. 
Figura 29 - Peças de Uniforme da Linha Aérea B. (a) (b) Peças P4 e P5 - Camisas masculinas, (c) Peça P6 - Paletó de 4 botões, (d) Peça P7 - Calça, formando conjunto de terno com a P6, (e) Peça P8 - Paletó de 1 botão. Indicação de escala de $10 \mathrm{~cm}$.

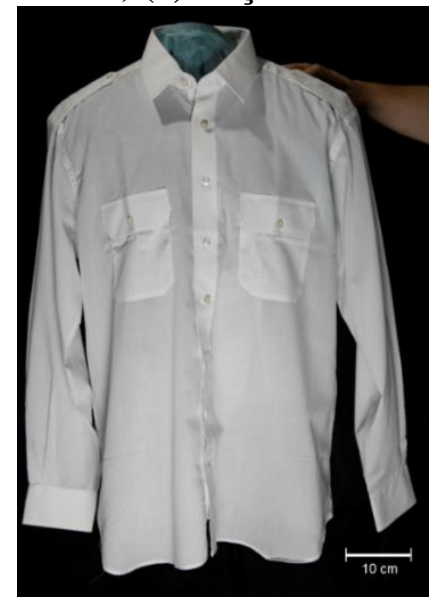

(a)

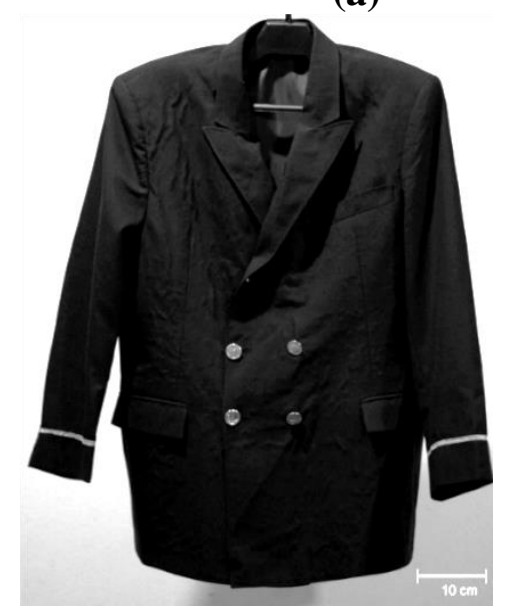

(c)

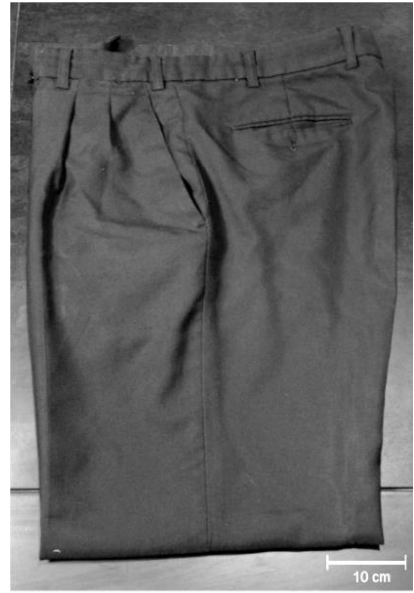

(d)

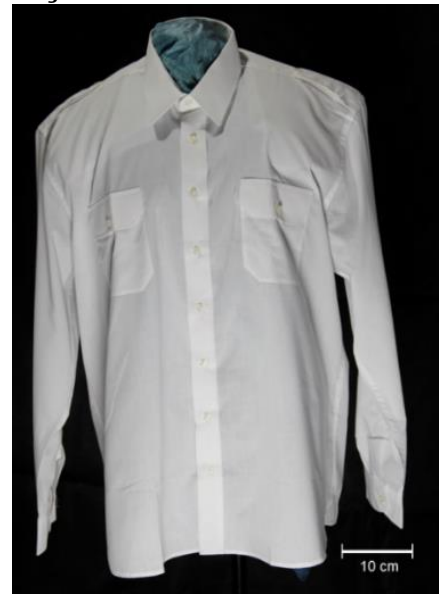

(b)

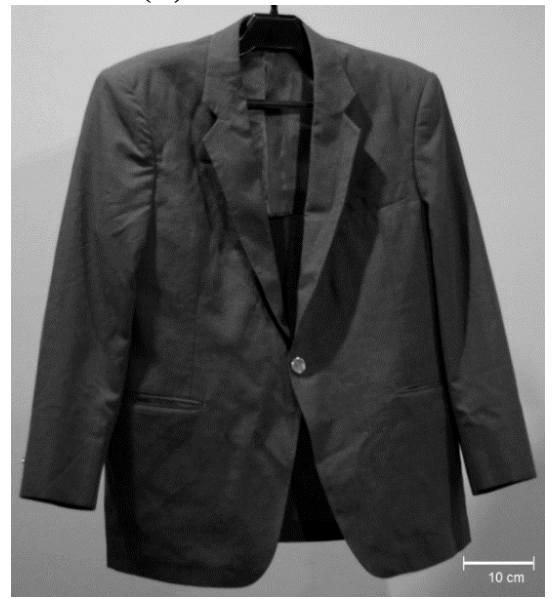

(e)

Fonte: Marcia Cristina Silva, 2017

\subsubsection{Dimensionamento das Peças de Uniforme}

O material têxtil disponível para o teste de inflamabilidade e posterior comparação de parâmetros foi retirado dos uniformes (Linha Aérea "A" e "B") e retalhos ("C"). Antes de descosturar as peças, cada uma foi medida conforme norma ABNT NBR 12071:2002Artigos Confeccionados para vestuário - Determinação das Dimensões (ASSOCIAÇÃO BRASILEIRA DE NORMAS TÉCNICAS, 2002) e foi possível estabelecer um plano de corte para obtenção das amostras.

As dimensões de cada peça de uniforme, com exceção do retalho R1 estão descritas na Tabela 6.1 com as medidas de 1 a 11 (conforme Figura 14) para as camisas e paletós e para a calça, as medidas de 1 a 9 (conforme Figura 15) são apresentadas na Tabela 6.2. 
Tabela 6.1 - Dimensões das Peças de Uniforme - Camisas e Paletós

\begin{tabular}{l|cccccccccccc}
\hline Peça & \multicolumn{11}{c}{ Medida (cm) } \\
\hline & & $\mathbf{1}$ & $\mathbf{2}$ & $\mathbf{3}$ & $\mathbf{4}$ & $\mathbf{5}$ & $\mathbf{6}$ & $\mathbf{7}$ & $\mathbf{8}$ & $\mathbf{9}$ & $\mathbf{1 0}$ & $\mathbf{1 1}$ \\
P1 & Camisa fem. A & 11,5 & 49,5 & 53,0 & 23,5 & 62,0 & 12,0 & 44,0 & 40,0 & 38,0 & 61,0 & 60,5 \\
P2 & Camisa fem. A & 13,0 & 52,0 & 56,0 & 21,0 & 60,0 & 10,5 & 42,0 & 41,5 & 40,0 & 68,5 & 64,5 \\
P3 & Camisa masc. A & 16,5 & 60,0 & 58,0 & 24,5 & 68,0 & 11,5 & 51,0 & 50,0 & 48,0 & 78,0 & 74,0 \\
P4 & Camisa masc. B & 20,5 & 64,0 & 66,0 & 26,0 & 64,0 & 11,0 & 43,0 & 51,0 & 50,0 & 82,5 & 78,0 \\
P5 & Camisa masc. B & 20,0 & 60,0 & 63,0 & 26,0 & 64,0 & 11,0 & 43,0 & 52,0 & 52,0 & 82,0 & 78,0 \\
P6 & Paletó masc. B & 16,5 & 70,0 & 70,0 & 28,0 & 59,0 & 15,5 & 44,0 & 50,0 & 49,0 & 76,5 & 76,5 \\
P8 & Paletó masc .B & 16,0 & 64,0 & 56,0 & 27,0 & 59,0 & 16,0 & 43,0 & 50,0 & 48,0 & 76,0 & 76,0 \\
\hline
\end{tabular}

(a) (1) comprimento do ombro, (2) tórax/busto, (3) cintura externa, (4) cava, (5) comprimento total manga,

(6) abertura da barra da manga - incluindo o punho - se houver, (6) abertura da barra da manga, (7) gola,

(8) largura de ombro a ombro, (9) largura das costas, (10) comprimento total traseiro, (11) comprimento total dianteiro.

Fonte: Marcia Cristina Silva, 2018.

Tabela 6.2 - Dimensões das Peças de Uniforme - Calça

\begin{tabular}{|c|c|c|c|c|c|c|c|c|c|c|}
\hline \multirow[t]{2}{*}{ Peça } & & \multicolumn{9}{|c|}{$\operatorname{Medida}^{(\mathbf{b})}(\mathrm{cm})$} \\
\hline & & 1 & 2 & 3 & 4 & 5 & 6 & 7 & 8 & 9 \\
\hline P7 & Calça masc. B & 44,0 & 58,0 & 78,0 & 23,0 & 48,0 & 30,0 & 28,0 & 22,0 & 108,0 \\
\hline
\end{tabular}

b) (1) cintura externa, (2) quadril $-7 \mathrm{~cm}$ acima da junção do gancho, (3) comprimento entre pernas, (4) comprimento do gancho dianteiro, (5) quadril alto $-3 \mathrm{~cm}$ abaixo do cós, excluindo-o, (6) comprimento do gancho traseiro, (7) coxa $-2 \mathrm{~cm}$ abaixo da junção do gancho, (8) abertura da barra, (9) comprimento total -excluindo o cós.

Fonte: Marcia Cristina Silva, 2018.

\subsection{CARACTERIZAÇÃO DOS MATERIAIS TÊXTEIS DOS UNIFORMES DOS AERONAUTAS E TECIDOS PROFISSIONAIS}

Algumas das características do material têxtil que influenciam no quadrilátero do fogo são o tipo de fibra, ligamento, densidade do fio, fator de cobertura e gramatura, consequentemente na velocidade de queima (FAN; LAO, 2009).

Uma análise preliminar das amostras obtidas de uniformes dos aeronautas, incluindo o retalho R1, indicou a utilização de: (i) tecido de algodão com gramatura pesada; (ii) tecido misto de algodão e poliéster com gramatura leve para as camisas e (iii) tecido $100 \%$ poliéster para os casacos masculinos e femininos. Assim, foram adquiridos no mercado tecidos similares, correspondentes respectivamente a T1, T2 e T3 (Tabela 5.1) para realização dos testes destrutivos e validação de protótipo para teste de chamas, preservando o material escasso dos uniformes profissionais. Os tecidos foram cortados nas dimensões de 100x100 mm e suas características básicas estão descritas a seguir: 
- T1 - Fornecedor Constâncio Vieira, Linha Profissional Sarja Work, material $100 \%$ algodão, gramatura $264 \mathrm{~g} / \mathrm{m}^{2}$, largura: $1,62 \mathrm{~m}$ e ligamento sarja $3 \times 1$;

- T2 - Fornecedor: Focus Têxtil, Linha Profissional, utilizado para confecção de jalecos de médicos, enfermeiros, roupas, saias, calças, vestidos e blazers, material100\% Poliéster, gramatura $173 \mathrm{~g} / \mathrm{m}^{2}$, largura 1,50 m e ligamento sarja $3 \times 1$;

- $\quad$ T3 - Fornecedor Toyobo do Brasil, Linha Profissional - Worker New, material: $67 \%$ poliéster $33 \%$ algodão, gramatura $112 \mathrm{~g} / \mathrm{m}^{2}$, largura: 1,60 $\mathrm{m}$, ligamento tela.

A informação sobre o material têxtil dos tecidos comprados foi retirada da descrição nos catálogos dos fornecedores e a composição têxtil das peças confeccionadas foi retirada da etiqueta.

As informações sobre a composição das fibras coletadas das etiquetas das peças de uniformes (P1 a P8) e das informações dos fornecedores dos tecidos profissionais (T1 a T3), foram realizados testes de FTIR para confirmar tais informações.

\subsubsection{Confirmação da composição das fibras dos tecidos por FTIR (Fourier Transform Infrared Spetroscopy)}

A análise qualitativa e quantitativa da estrutura química das fibras empregadas nos tecidos profissionais (T1 a T3) e das peças de uniformes de aeronautas (P1 a P8) foi confirmada através da técnica de espectroscopia na região do infravermelho médio, realizando 32 varreduras com resolução de $2 \mathrm{~cm}^{-1}$. Esta análise é possível porque os átomos que formam as moléculas vibram em frequências diferentes. A variação ocorre de acordo com a estrutura, composição e modo de vibração da amostra.

A seguir, as Figuras 30 a 32 apresentam a comparação dos espectros obtidos da

composição de fibras dos experimentos com aqueles dos padrões armazenados na biblioteca do equipamento Thermo Avatar 370 FTIR. 
Figura 30 - Resultados da determinação do FTIR da análise dos tecidos em comparação ao padrão da biblioteca do equipamento Thermo Avatar 370 FTIR: (a) padrão 100\% Algodão - CO (vermelho) e para o tecido profissional T1 (verde); (b) padrão $100 \%$ Poliéster - PES (vermelho) e para o tecido profissional T3 (lilás).

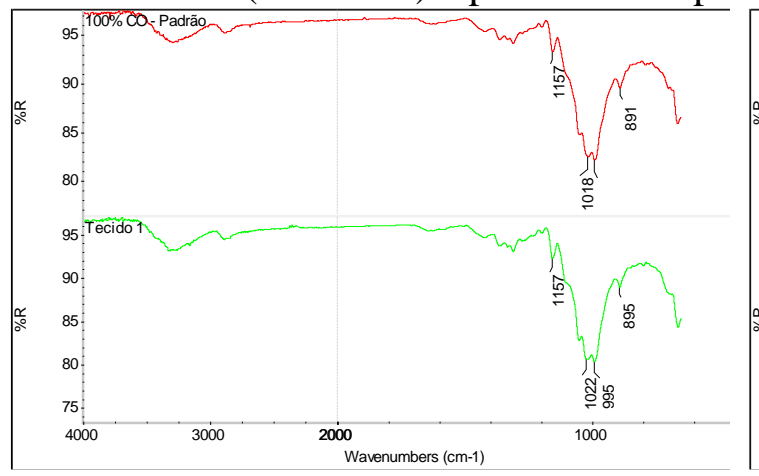

(a)

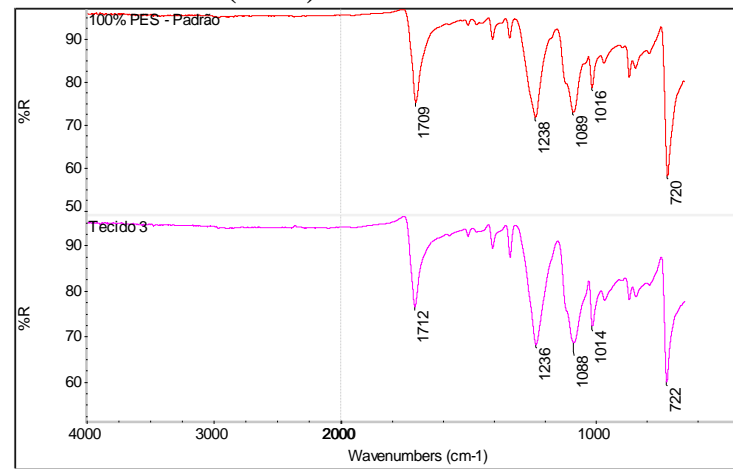

(b)

Fonte: Leonardi (2018)

Figura 31 - Resultados da determinação do FTIR da análise dos tecidos em comparação ao padrão da biblioteca do equipamento Thermo Avatar 370 FTIR: (a) padrão 50\% Algodão CO e 50\% Poliéster PES (vermelho) e para o tecido profissional T2 (azul claro); (b) padrão $50 \%$ Algodão - CO e 50\% Poliéster PES (preto) e para o tecido da peça P1 (azul), peça P2 (verde), peça P3 (vermelho).

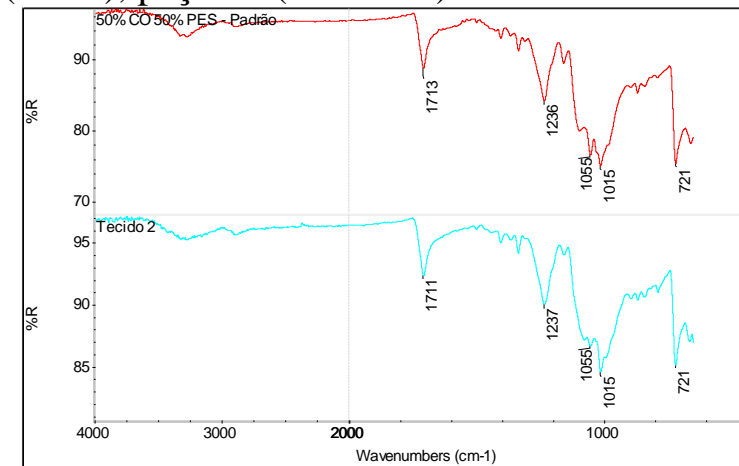

(a)

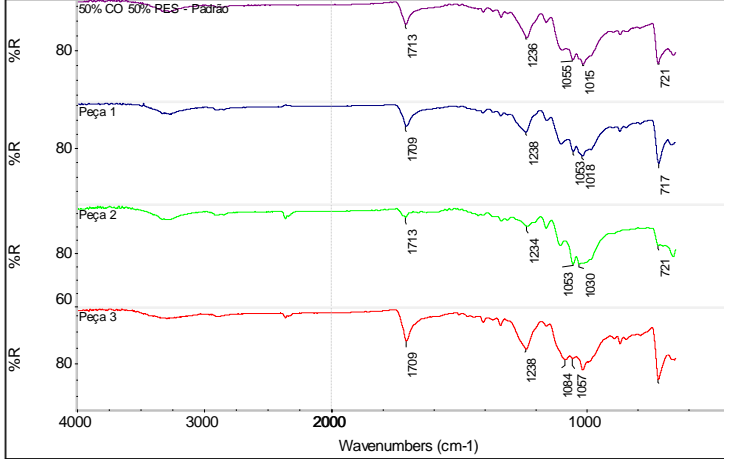

(b)

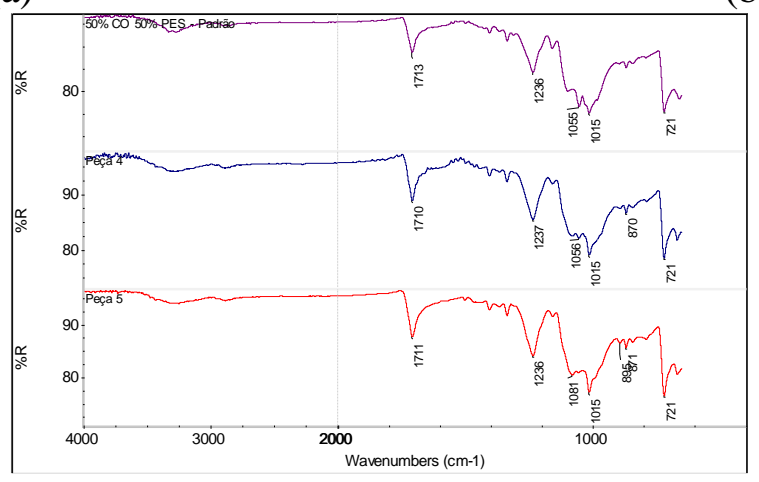

(c)

Fonte: Leonardi (2018) 
Figura 32 - Resultados da determinação do FTIR da análise dos tecidos em comparação ao padrão da biblioteca do equipamento Thermo Avatar 370 FTIR: (a) padrão 100\% Poliéster PES (vermelho) e 100\% Lã WO (verde) para o tecido da peça P6 (laranja), peça P7 (azul); (b) padrão 100\% Poliéster PES (verde escuro) e 100\% Lã WO (verde claro) para o tecido da peça P8 (vermelho).

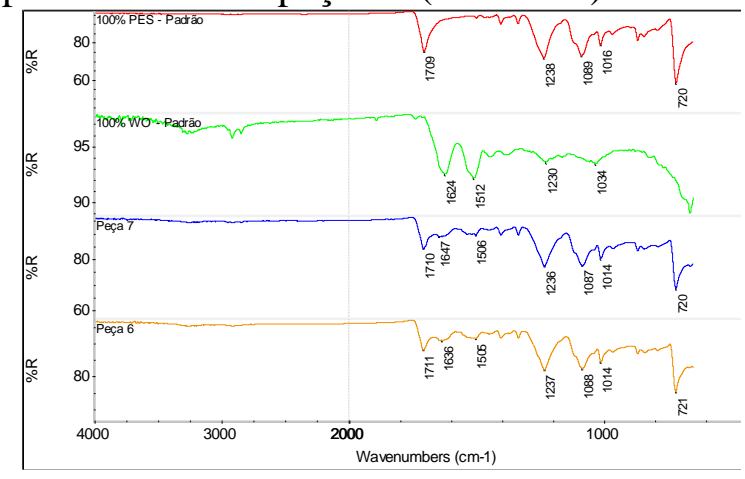

(a)

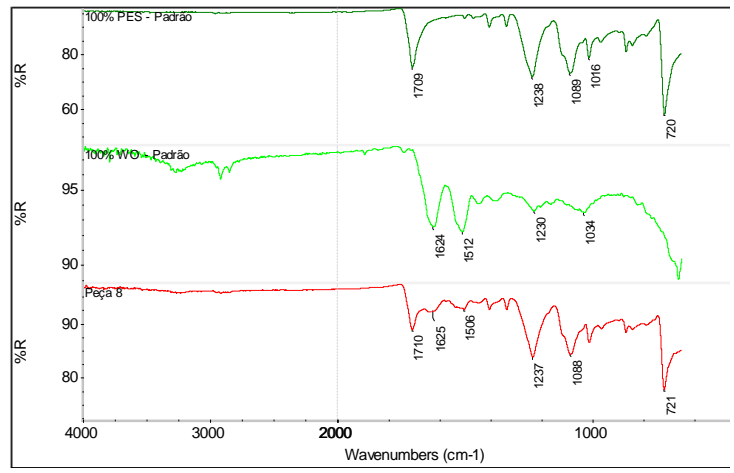

(b)

Fonte: Leonardi (2018)

Nos resultados apresentados na Figura 31, pode-se observar a similaridade de ambos os espectros (padrões e tecidos analisados). No caso 100\% Algodão e mescla Algodão/Poliéster, ainda que os valores da composição dos tecidos de mescla (67\% CO/33\% PES) não sejam os mesmos do padrão (50\% CO/50\% PES) e por ser a análise qualitativa, não se busca a definição das proporções, mas sim a presença do material. Deste modo é confirmado que os tecidos analisados neste caso são compostos de mescla Algodão/Poliéster.

Na Figura 32, a biblioteca do equipamento não possui um padrão de mescla Lã/Poliéster, desse modo se usaram os padrões separados correspondentes a $100 \%$ Poliéster e 100\% Lã. Na comparação dos espectros dos tecidos com os dos padrões é possível verificar a presença dos picos característicos dos padrões de lã e de poliéster nos espectros dos tecidos, não se encontrando nenhum pico que não se enquadre no espectro dos padrões. Isso confirma qualitativamente que os tecidos analisados são mescla de lã com poliéster.

Deste modo, as análises de FTIR confirmam as informações de etiquetas para todos os tecidos analisados neste estudo.

\subsubsection{Ligamento, fios de trama e urdume, espessura e gramatura}

Com uma lente conta fios de base graduada foi determinado o ligamento (Item 5.2.3) e estabelecida a densidade de fios na direção da trama e urdume dos tecidos comprados (T1 a T3) e dos tecidos dos uniformes (P1 a P8) (Item 5.2.4). 
Outra característica verificada nessa fase foi a espessura (item 5.2.5) que para os tecidos dos uniformes dos aeronautas, por se tratar de amostras pequenas, a medição foi feita em dez lugares diferentes sem destruí-las.

A determinação da massa por unidade de área ou gramatura foi realizada em duas etapas, sendo parte na Universidade do Minho em Portugal e concluída na Universidade de São Paulo. Para calcular a gramatura (Item 5.2.6), as peças de uniformes P1 a P8 foi descosturada e cortada em amostras de dimensões 100x100 mm, totalizando 10 amostras. Após climatizadas e pesadas, foi possível calcular a gramatura dos tecidos conforme Equação 1. As características dos tecidos profissionais (T1 a T3) e dos materiais têxteis dos uniformes (P1 a P8), ou seja, a composição, ligamento, densidade de fios, espessura e gramatura são apresentados na Tabela 6.3.

Tabela 6.3 - Características dos Tecidos dos Uniformes de Aeronautas e Tecidos adquiridos no mercado, expressos em tipo fibra (composição do material, sendo CO algodão, PES - poliéster e WO - lã), ligamento, densidade de fios (TR, número de fios por $\mathrm{cm}$ na trama e UR, número de fios por $\mathrm{cm}$ no urdume), espessura e gramatura. Estes dois últimos, expressos em termos de média e desvio padrão de 10 medições e entre parênteses é indicado o coeficiente de variação.

\begin{tabular}{|c|c|c|c|c|c|c|c|}
\hline & & Material* & Ligamento & TR & UR & Espessura (mm) & Gramatura $\left(\mathrm{g} / \mathrm{m}^{2}\right)$ \\
\hline T1 & Tecido & $100 \% \mathrm{CO}$ & Sarja $3 \times 1$ & 16 & 23 & $\begin{array}{c}\mathbf{0 , 5 0 4} \pm 0,008 \\
(1,67 \%)\end{array}$ & $\begin{array}{c}\mathbf{2 3 5 , 0 4} \pm 0,67 \\
(0,29 \%)\end{array}$ \\
\hline $\mathbf{T 2}$ & Tecido & $67 \%$ PES $33 \%$ CO & Tela & 28 & 46 & $\begin{array}{c}\mathbf{0 , 1 9 8} \pm 0,004 \\
(2,13 \%)\end{array}$ & $\begin{array}{c}\mathbf{1 0 4 , 2 0} \pm 1,28 \\
(1,23 \%)\end{array}$ \\
\hline T3 & Tecido & $100 \%$ PES & Sarja $2 \times 1$ & 28 & 46 & $\begin{array}{c}\mathbf{0 , 3 8 2} \pm 0,004 \\
(1,10 \%)\end{array}$ & $\begin{array}{c}\mathbf{1 6 0 , 9 4} \pm 1,78 \\
(1,10 \%)\end{array}$ \\
\hline P1 & Camisa fem. A & $100 \%$ PES & Sarja $2 \times 2$ & 27 & 29 & $\begin{array}{c}\mathbf{0 , 2 6 0} \pm 0,007 \\
(2,84 \%)\end{array}$ & $\begin{array}{c}\mathbf{1 0 9 , 5 2} \pm 0,75 \\
(0,69 \%)\end{array}$ \\
\hline $\mathbf{P 2}$ & Camisa fem. A & $100 \% \mathrm{PES}$ & Tela & 34 & 40 & $\begin{array}{c}\mathbf{0 , 2 1 0} \pm 0,007 \\
(3,44 \%)\end{array}$ & $\begin{array}{c}\mathbf{9 5 , 0 9} \pm 2,93 \\
(3,08 \%)\end{array}$ \\
\hline P3 & Camisa masc. A & $67 \% \mathrm{PES} / 33 \% \mathrm{CO}$ & Sarja $2 \times 1$ & 24 & 39 & $\begin{array}{c}\mathbf{0 , 3 9 0} \pm 0,012 \\
(3,06 \%)\end{array}$ & $\begin{array}{c}\mathbf{1 9 5 , 5 1} \pm 1,03 \\
(0,53 \%)\end{array}$ \\
\hline P4 & Camisa masc. B & $67 \% \mathrm{PES} / 33 \% \mathrm{CO}$ & Tela & 26 & 35 & $\begin{array}{c}\mathbf{0 , 2 2 0} \pm 0,005 \\
(2,16 \%)\end{array}$ & $\begin{array}{c}\mathbf{1 0 5 , 8 9} \pm 1,33 \\
(1,25 \%)\end{array}$ \\
\hline P5 & Camisa masc. B & $67 \% \mathrm{PES} / 33 \% \mathrm{CO}$ & Tela & 26 & 35 & $\begin{array}{c}\mathbf{0 , 2 3 0} \pm 0,007 \\
(2,90 \%)\end{array}$ & $\begin{array}{c}\mathbf{1 0 8 , 7 2} \pm 2,39 \\
(2,20 \%)\end{array}$ \\
\hline P6 & Paletó masc. B & $55 \% \mathrm{PES} / 45 \% \mathrm{WO}$ & Tela & 22 & 22 & $\begin{array}{c}\mathbf{0 , 3 6 0} \pm 0,011 \\
(2,93 \%)\end{array}$ & $\begin{array}{c}\mathbf{1 7 9 , 9 6} \pm 1,27 \\
(0,70 \%)\end{array}$ \\
\hline P7 & Calça masc. B & $50 \% \mathrm{PES} / 50 \% \mathrm{WO}$ & Tela & 20 & 22 & $\begin{array}{c}\mathbf{0 , 4 5 0} \pm 0,020 \\
(4,509 \%)\end{array}$ & $\begin{array}{c}\mathbf{2 2 5}, \mathbf{1 2} \pm 5,02 \\
(2,23 \%)\end{array}$ \\
\hline P8 & Paletó masc. B & $55 \% \mathrm{PES} / 45 \% \mathrm{WO}$ & Tela & 22 & 22 & $\begin{array}{c}\mathbf{0 , 3 5 0} \pm 0,007 \\
(1,90 \%)\end{array}$ & $\begin{array}{c}\mathbf{1 6 8 , 0 4} \pm 1,98 \\
(1,18 \%) \\
\end{array}$ \\
\hline
\end{tabular}

Etiqueta da peça ou informação do fornecedor.

Fonte: Marcia Cristina Silva, 2018

\subsubsection{Densidade Linear e Torções do Fio}

Os valores determinados de densidade linear e torções dos fios referentes aos tecidos adquiridos no mercado (T1 a T3) e dos uniformes de aeronautas (P1 a P8) estão apresentados a seguir na Tabela 6.4. 
Tabela 6.4 - Características de densidade linear e torções dos fios de trama e urdume retirados dos tecidos adquiridos no mercado e dos Uniformes de Aeronautas. Os valores estão expressos em termos de média e desvio padrão de 10 medições e entre parênteses é indicado o coeficiente de variação.

\begin{tabular}{|c|c|c|c|c|c|c|}
\hline & & \multicolumn{2}{|c|}{$\begin{array}{c}\text { Densidade linear do Fio } \\
\text { (tex) }\end{array}$} & \multicolumn{3}{|c|}{ Torções/m } \\
\hline & & Trama & Urdume & Trama & Urdume & $\begin{array}{l}\text { Sentido } \\
\text { torç̃es }\end{array}$ \\
\hline $\mathbf{T 1}$ & Tecido & $\begin{array}{c}\mathbf{5 9 , 6 2} \pm 2,68 \\
(4,48 \%)\end{array}$ & $\begin{array}{c}\mathbf{3 5}, \mathbf{3 0} \pm 1,82 \\
(5,16 \%)\end{array}$ & $\begin{array}{c}\mathbf{5 0 2}, \mathbf{2 0} \pm 34,93 \\
(6,95 \%)\end{array}$ & $\begin{array}{c}\mathbf{7 0 5}, \mathbf{4 0} \pm 13,38 \\
(1,90 \%)\end{array}$ & $\mathrm{Z}$ \\
\hline $\mathbf{T} 2$ & Tecido & $\begin{array}{c}\mathbf{1 2 , 6 7 \pm 0 , 7 5} \\
(5,90 \%)\end{array}$ & $\begin{array}{c}\mathbf{3 7 , 2 7} \pm 1,89 \\
(5,07 \%)\end{array}$ & $\begin{array}{c}\mathbf{1 0 6 9 , 5 0} \pm 56,90 \\
(5,32 \%)\end{array}$ & $\begin{array}{l}\mathbf{9 8 9 , 7 5} \pm 75,74 \\
(7,15 \%)\end{array}$ & S \\
\hline $\mathbf{T 3}$ & Tecido & $\begin{array}{c}\mathbf{1 6 , 9 6} \pm 0,24 \\
(1,41 \%)\end{array}$ & $\begin{array}{c}\mathbf{1 8 , 1 6} \pm 0,24 \\
(1,34 \%)\end{array}$ & - & - & - \\
\hline P1 & Camisa fem. A & $\begin{array}{c}\mathbf{1 6 , 8 2} \pm 0,29 \\
(1,70 \%)\end{array}$ & $\begin{array}{c}\mathbf{1 8 , 1 6} \pm 0,24 \\
(1,34 \%)\end{array}$ & - & $\begin{array}{c}\mathbf{8 9 1 , 2 5} \pm 25,33 \\
(2,84 \%)\end{array}$ & - \\
\hline P2 & Camisa fem. A & $\begin{array}{c}\mathbf{1 3 , 6 7} \pm 0,54 \\
(3,96 \%)\end{array}$ & $\begin{array}{c}\mathbf{9 , 2 7} \pm 0,43 \\
(4,60 \%)\end{array}$ & - & - & - \\
\hline P3 & $\begin{array}{c}\text { Camisa masc. } \\
\text { A }\end{array}$ & $\begin{array}{c}\mathbf{3 0 , 8 5} \pm 1,50 \\
(4,85 \%)\end{array}$ & $\begin{array}{c}\mathbf{2 5 , 4 3} \pm 1,35 \\
(5,31 \%)\end{array}$ & - & - & - \\
\hline P4 & $\begin{array}{c}\text { Camisa masc. } \\
\text { B }\end{array}$ & $\begin{array}{c}\mathbf{1 5 , 7 7 \pm 1 , 0 8} \\
(6,82 \%)\end{array}$ & $\begin{array}{c}\mathbf{1 4 , 7 6} \pm 1,29 \\
(8,74 \%)\end{array}$ & $\begin{array}{c}\mathbf{9 8 6 , 0 0} \pm 62,19 \\
(6,30 \%)\end{array}$ & $\begin{array}{c}\mathbf{8 5 7}, \mathbf{2 5} \pm 72,19 \\
(8,42 \%)\end{array}$ & $\mathrm{Z}$ \\
\hline P5 & $\begin{array}{c}\text { Camisa masc. } \\
\text { B }\end{array}$ & $\begin{array}{c}\mathbf{1 5 , 8 8} \pm 1,27 \\
(8,01 \%)\end{array}$ & $\begin{array}{c}\mathbf{1 5 , 1 9} \pm 1,33 \\
(8,73 \%)\end{array}$ & $\begin{array}{c}\mathbf{9 9 1 , 0 0} \pm 45,75 \\
(4,61 \%)\end{array}$ & $\begin{array}{c}\mathbf{9 1 0 , 0 0} \pm 79,90 \\
(8,77 \%)\end{array}$ & $\mathrm{Z}$ \\
\hline P6 & Paletó masc. B & $\begin{array}{c}\mathbf{3 6}, \mathbf{7 2} \pm 3,43 \\
(9,35 \%)\end{array}$ & $\begin{array}{c}\mathbf{3 5 , 8 8} \pm 2,31 \\
(6,43 \%)\end{array}$ & $\begin{array}{c}\mathbf{5 4 9 , 0 0} \pm 47,48 \\
(8,65 \%)\end{array}$ & $\begin{array}{c}\mathbf{5 5 6 , 0 0} \pm 34,78 \\
(6,25 \%)\end{array}$ & S \\
\hline P7 & Calça masc. B & $\begin{array}{c}\mathbf{3 6 , 6 1} \pm 1,48 \\
(4,19 \%)\end{array}$ & $\begin{array}{c}\mathbf{3 5}, \mathbf{3 1} \pm 2,25 \\
(6,36 \%)\end{array}$ & $\begin{array}{c}\mathbf{5 9 8 , 0 0} \pm 45,34 \\
(7,57 \%)\end{array}$ & $\begin{array}{l}\mathbf{5 6 2 , 0 0} \pm 58,55 \\
(10,49 \%)\end{array}$ & S \\
\hline P8 & Paletó masc. B & $\begin{array}{c}\mathbf{3 6 , 0 3} \pm 3,38 \\
(9,38 \%)\end{array}$ & $\begin{array}{c}\mathbf{3 5 , 6 8} \pm 1,99 \\
(5,58 \%)\end{array}$ & $\begin{array}{c}\mathbf{5 0 7}, \mathbf{5 0} \pm 40,91 \\
(8,06 \%)\end{array}$ & $\begin{array}{l}\mathbf{5 4 8 , 0 0} \pm 40,50 \\
(7,40 \%)\end{array}$ & S \\
\hline
\end{tabular}

Observa-se que na Tabela 6.4, não estão indicados os valores de torções para trama e urdume de T3, P2 e P3 e para a trama de P1.

No caso dos fios de T3, P2 e fios de trama de P1 (todos 100\% PES), isto é, devido a serem fios intermigled, ou seja, cujos filamentos de poliéster são agrupados por processo térmico, portanto são fios não torcidos. Possuem uma estrutura distinta de um fio com filamentos que ao invés de serem torcidos, são emaranhados em alguns pontos (mingled points). O fio intermigled aparenta estar com os filamentos agrupados de uma forma bem justa nos pontos de agrupamento e distribuídos de forma regular ao longo do fio (CHATTOPADHY, 2010).

No caso dos fios de P3 (67\%PES/33\%CO), estes são fios core-spun, cuja principal característica é aplicação de fibras (bainha) cortados em um fio existente (núcleo). A combinação permite selecionar fibras para o núcleo e a bainha com propriedades para atender a uma aplicação específica (CHATTOPADHY, 2010). 


\subsubsection{Diâmetro do fio}

Os valores determinados para diâmetro dos fios referentes aos tecidos adquiridos no mercado (T1 a T3) e dos uniformes de aeronautas (P1 a P8) foram medidos por microscopia óptica: (i) em sua vista longitudinal (determinação da largura), com aumento de 80 vezes; (ii) através de medição dos eixos perpendiculares e (iii) através da medição da circunferência, feitas na vista transversal com aumento de 128 vezes, conforme metodologia expressa no Item 5.2.4. Os valores de diâmetro, determinados para os fios de trama e urdume, nos três modos de medição, estão apresentados a seguir na Tabela

\section{5.}

Tabela 6.5 - Valores de diâmetro em mm, determinados para os fios de trama e urdume, nos três modos de medição (largura, por eixos perpendiculares e por circunferência) dos tecidos adquiridos no mercado e dos uniformes de aeronautas. Os valores estão expressos em termos de média e desvio padrão de 10 medições e entre parênteses é indicado o coeficiente de variação.

\begin{tabular}{|c|c|c|c|c|c|c|c|}
\hline & & \multicolumn{2}{|c|}{ LARGURA } & \multicolumn{2}{|c|}{$\begin{array}{c}\text { POR EIXOS } \\
\text { PERPENDICULARES }\end{array}$} & \multicolumn{2}{|c|}{ POR CIRCUNFERÊNCIA } \\
\hline & & Trama & Urdume & Trama & Urdume & Trama & Urdume \\
\hline T1 & Tecido & $\begin{array}{c}\mathbf{0 , 3 3 1 9} \pm 0,0316 \\
(9,53 \%)\end{array}$ & $(5,47 \%)$ & $\begin{array}{c}\mathbf{0 , J / 8} / \pm 0,0311 \\
(8,21 \%)\end{array}$ & $\begin{array}{c}\mathbf{0 , 2 7 1 7} \pm 0,0327 \\
(12,05 \%)\end{array}$ & $\begin{array}{c}\mathbf{0 , 4 3 5 4} \pm 0,0361 \\
(8,30 \%)\end{array}$ & $\begin{array}{c}\mathbf{0 , 2 7 6 0} \pm 0,0475 \\
(17,21 \%)\end{array}$ \\
\hline $\mathbf{T} 2$ & Tecido & $\begin{array}{c}\mathbf{0 , 3 5 4 4} \pm 0,0231 \\
(6,53 \%)\end{array}$ & & $\begin{array}{c}\mathbf{0 , 3 6 7 2} \pm 0,0441 \\
(12,02 \%)\end{array}$ & & $\begin{array}{c}\mathbf{0 , 4 3 7 6} \pm 0,0738 \\
(16,87 \%)\end{array}$ & $\begin{array}{c}\mathbf{0 , 3 1 0 6} \pm 0,0493 \\
(15,87 \%)\end{array}$ \\
\hline $\mathbf{T 3}$ & Tecido & $\begin{array}{c}\mathbf{0 , 1 5 0 3} \pm 0,0150 \\
(9,96 \%)\end{array}$ & $\begin{array}{c}\mathbf{0 , 1 9 0 2} \pm 0,0337 \\
(17,72 \%)\end{array}$ & $\begin{array}{c}\mathbf{0 , 2 1 9 2} \pm 0,0081 \\
(3,68 \%)\end{array}$ & $\begin{array}{c}\mathbf{0 , 1 7 1 1} \pm 0,0318 \\
(15,59 \%)\end{array}$ & $\begin{array}{c}\mathbf{0 , 2 1 5 1} \pm 0,0186 \\
(8,64 \%)\end{array}$ & $\begin{array}{c}\mathbf{0 , 1 6 4 9} \pm 0,0300 \\
(18,17 \%)\end{array}$ \\
\hline P1 & $\begin{array}{l}\text { Camisa } \\
\text { fem. A }\end{array}$ & $\begin{array}{c}\mathbf{0 , 4 6 8 8} \pm 0,0164 \\
(3,50 \%)\end{array}$ & & $\begin{array}{l}\mathbf{0 , 5 2 7 7} \pm 0,0537 \\
(10,19 \%)\end{array}$ & $\begin{array}{c}\mathbf{0 , 1 8 6 6} \pm 0,0111 \\
(5,94 \%)\end{array}$ & $\begin{array}{c}\mathbf{0 , 5 7 2 0} \pm 0,0565 \\
(9,88 \%)\end{array}$ & $\begin{array}{c}\mathbf{0 , 1 9 8 9} \pm 0,0056 \\
(2,83 \%)\end{array}$ \\
\hline $\mathbf{P 2}$ & $\begin{array}{l}\text { Camisa } \\
\text { fem. A }\end{array}$ & $\mathbf{0 , 1 7 3 9} \pm 0,0148$ & $\mathbf{0 , 1 9 5 8} \pm 0,0189$ & $\begin{array}{c}\mathbf{0 , 1 9 1 6} \pm 0,0154 \\
(8,06 \%)\end{array}$ & $\begin{array}{c}\mathbf{0 , 3 2 0 6} \pm 0,0453 \\
(14,13 \%)\end{array}$ & $\begin{array}{c}\mathbf{0 , 2 0 8 3} \pm 0,0104 \\
(5,01 \%)\end{array}$ & $\begin{array}{c}\mathbf{0 , 3 8 0 6} \pm 0,0867 \\
(22,80 \%)\end{array}$ \\
\hline $\mathbf{P 3}$ & $\begin{array}{c}\text { Camisa } \\
\text { masc. } \\
\text { A }\end{array}$ & $\begin{array}{r}\mathbf{0 , 3 0 1} \\
(14\end{array}$ & $\begin{array}{r}\mathbf{0 , 2 3 4 0 \pm} \\
\quad(9,28\end{array}$ & $\begin{array}{c}\mathbf{0 , 2 6 5 9} \pm 0,0272 \\
(10,25 \%)\end{array}$ & $\begin{array}{c}\mathbf{0 , 2 8 1 4} \pm 0,0277 \\
(9,86 \%)\end{array}$ & $\begin{array}{r}\mathbf{0 , 2 6 8} \\
(6,\end{array}$ & $\begin{array}{c}\mathbf{0 , 3 0 9 1} \pm 0,0416 \\
(13,46 \%)\end{array}$ \\
\hline P4 & $\begin{array}{c}\text { Camisa } \\
\text { masc. } \\
\text { B }\end{array}$ & $\begin{array}{c}\mathbf{0 , 2 0 6 0} \pm 0,0227 \\
(11,01 \%)\end{array}$ & $\begin{array}{c}\mathbf{0 , 3 2 0 0} \pm 0,0188 \\
(5,87 \%)\end{array}$ & $\begin{array}{c}\mathbf{0 , 1 9 1 0} \pm 0,0217 \\
(11,36 \%)\end{array}$ & $\begin{array}{c}\mathbf{0 , 1 8 0 6} \pm 0,0303 \\
(16,77 \%)\end{array}$ & $\begin{array}{c}\mathbf{0 , 1 8 7 7} \pm 0,0197 \\
(10,50 \%)\end{array}$ & $\begin{array}{c}\mathbf{0 , 1 8 1 3} \pm 0,0360 \\
(19,85 \%)\end{array}$ \\
\hline P5 & $\begin{array}{c}\text { Camisa } \\
\text { masc. } \\
\text { B }\end{array}$ & $\begin{array}{c}\mathbf{0 , 1 9 4 0} \pm 0,0359 \\
(18,50 \%)\end{array}$ & $\begin{array}{c}\mathbf{0 , 2 0 1 0} \pm 0,0185 \\
(9,20 \%)\end{array}$ & $\begin{array}{c}\mathbf{0 , 2 3 4 2} \pm 0,0254 \\
(10,84 \%)\end{array}$ & $\begin{array}{c}\mathbf{0 , 2 2 1 1} \pm 0,0269 \\
(12,16 \%)\end{array}$ & $\begin{array}{c}\mathbf{0 , 2 3 0 0} \pm 0,0168 \\
(7,30 \%)\end{array}$ & $\begin{array}{c}\mathbf{0 , 2 2 7 9} \pm 0,0283 \\
(12,41 \%)\end{array}$ \\
\hline P6 & $\begin{array}{c}\text { Paletó } \\
\text { masc. } \\
\text { B }\end{array}$ & $\begin{array}{c}\mathbf{0 , 3 1 3 0} \pm 0,0409 \\
(13,06 \%)\end{array}$ & $\begin{array}{c}\mathbf{0 , 3 5 6 0} \pm 0,0279 \\
(7,83 \%)\end{array}$ & $\begin{array}{c}\mathbf{0 , 3 7 4 9} \pm 0,0550 \\
(14,67 \%)\end{array}$ & $\begin{array}{c}\mathbf{0 , 3 5 8 7} \pm 0,0334 \\
(9,31 \%)\end{array}$ & $\begin{array}{c}\mathbf{0 , 4 0 3 9} \pm 0,0581 \\
(14,38 \%)\end{array}$ & $\begin{array}{c}\mathbf{0 , 4 2 6 0} \pm 0,0562 \\
(13,19 \%)\end{array}$ \\
\hline P7 & $\begin{array}{c}\text { Calça } \\
\text { masc. } \\
\text { B }\end{array}$ & $\begin{array}{c}\mathbf{0 , 2 9 2 2} \pm 0,0446 \\
(15,26 \%)\end{array}$ & $\begin{array}{c}\mathbf{0 , 3 2 4 0} \pm 0,0478 \\
(14,75 \%)\end{array}$ & $\begin{array}{c}\mathbf{0 , 3 6 5 5} \pm 0,0168 \\
(4,59 \%)\end{array}$ & $\begin{array}{c}\mathbf{0 , 3 6 5 2} \pm 0,0331 \\
(9,06 \%)\end{array}$ & $\begin{array}{c}\mathbf{0 , 3 9 8 5} \pm 0,0278 \\
(6,97 \%)\end{array}$ & $\begin{array}{c}\mathbf{0 , 4 2 4 4} \pm 0,0715 \\
(16,84 \%)\end{array}$ \\
\hline P8 & $\begin{array}{c}\text { Paletó } \\
\text { masc. } \\
\text { B } \\
\end{array}$ & $\begin{array}{c}\mathbf{0 , 2 5 1 1} \pm 0,0271 \\
(10,79 \%)\end{array}$ & $\begin{array}{c}\mathbf{0 , 2 4 0 0} \pm 0,0362 \\
(15,08 \%)\end{array}$ & $\begin{array}{c}\mathbf{0 , 2 9 5 0} \pm 0,0240 \\
(8,13 \%)\end{array}$ & $\begin{array}{c}\mathbf{0 , 3 3 5 1} \pm 0,0253 \\
(7,54 \%)\end{array}$ & $\begin{array}{c}\mathbf{0 , 3 3 5 1} \pm 0,0395 \\
(11,78 \%)\end{array}$ & $\begin{array}{c}\mathbf{0 , 3 8 8 5} \pm 0,0446 \\
(11,48 \%)\end{array}$ \\
\hline
\end{tabular}

Fonte: Marcia Cristina Silva, 2018

Com o propósito de escolher teste apropriado para a comparação entre as médias obtidas nos três modos de medição, torna-se necessário conhecer o padrão de distribuição 
dos dados e a verificação da igualdade de variância das variáveis. A hipótese nula considera uma afirmação, ou seja, para o teste de normalidade o conjunto de dados da variável diâmetro do fio apresenta distribuição normal e para o teste de igualdade de variâncias os modos de medição, apresentam a mesma variância. A decisão foi tomada no nível de significância de $5 \%$ (p-value $\geq 0,05$ ).

Para cada conjunto de 10 medidas em cada determinação foi realizado um teste de normalidade da distribuição dos dados (totalizando 66 análises).

Para as medições de largura em vista longitudinal, todas as análises apresentam pvalue maior que 0,05 caracterizando a distribuição normal dos dados. Para as medições por eixos perpendiculares, somente os grupos de medições para fios de trama de P4 $(\mathrm{p}<0,005)$ e fios de trama em P7 ( $\mathrm{p}=0,023)$, não apresentaram distribuição normal. Para as medições por circunferência, somente os grupos para fios de urdume de $\mathrm{T} 1(\mathrm{p}<0,005)$, fios de urdume de P3 ( $\mathrm{p}=0,026)$ e fios de trama de P4 $(\mathrm{p}<0,005)$, não apresentaram distribuição normal.

Em seguida foram realizados os testes de igualdade de variância, para todos os conjuntos de medidas entre os três modos de medição (totalizando 22 análises). Constatou-se que ocorreu igualdade de variâncias entre os três modos distintos de medições para todos os fios, com exceção dos fios de urdume de T2 $(\mathrm{p}=0,006)$ e fios de urdume de P2 ( $\mathrm{p}=0,002)$.

Para todos os conjuntos de medidas entre os três modos de medição nos quais houve condição de normalidade e igualdade de variâncias, foi realizado o Teste de ANOVA, para determinação de diferenças entre as médias (totalizando 16 análises). A hipótese nula confirma que as três médias são igual no nível de significância de $5 \%$. Somente foi constatada igualdade das médias entre os métodos nos casos de fios de urdume de T3 ( $\mathrm{p}=0,153)$, fios de trama de P3 $(\mathrm{p}=0,076)$, fios de trama de P5 $(\mathrm{p}=0,14)$ e fios de urdume de P5 ( $\mathrm{p}=0,063)$.

Deste modo se conclui que os três métodos de medição (largura, por eixos perpendiculares e por circunferência) fornecem valores que apresentam diferenças estatisticamente significativas, ou seja, pode se entender que os valores diferem significativamente entre si. Assim não se pode creditar a validade de um deles em detrimento dos outros.

Em virtude disso, optou-se pela determinação dos diâmetros dos fios empregando o modelo geométrico de Peirce (Figura 5.6), descrito no item 5.2.8 e Equação 7. 
Os valores de diâmetro calculados pelo modelo geométrico de Peirce para os fios dos tecidos, estão expressos na Tabela 6.6

Tabela 6.6 - Valores de diâmetro (mm), calculados para os fios de trama e urdume considerando o fio com seção circular (Equação 6) e calculados pelo modelo de Peirce (Equação 7)

\begin{tabular}{|c|crrrr}
\hline \multicolumn{5}{c}{ Seção Circular } & \multicolumn{2}{c}{ Modelo de Peirce } \\
\hline & & Trama & Urdume & Trama & Urdume \\
T1 & Tecido & 0,224 & 0,172 & 0,289 & 0,222 \\
T2 & Tecido & 0,106 & 0,182 & 0,132 & 0,226 \\
T3 & Tecido & 0,125 & 0,129 & 0,155 & 0,161 \\
P1 & Camisa fem. A & 0,125 & 0,131 & 0,155 & 0,163 \\
P2 & Camisa fem. A & 0,112 & 0,092 & 0,139 & 0,115 \\
P3 & Camisa masc. A & 0,166 & 0,151 & 0,206 & 0,187 \\
P4 & Camisa masc. B & 0,119 & 0,115 & 0,147 & 0,142 \\
P5 & Camisa masc. B & 0,119 & 0,116 & 0,148 & 0,144 \\
P6 & Paletó masc. B & 0,186 & 0,184 & 0,240 & 0,237 \\
P7 & Calça masc. B & 0,177 & 0,176 & 0,219 & 0,218 \\
P8 & Paletó masc. B & 0,184 & 0,183 & 0,228 & 0,227 \\
\hline
\end{tabular}

Fonte: Marcia Cristina Silva, 2018

Os valores calculados de diâmetro considerando o fio com seção circular são ligeiramente inferiores aos calculados com o modelo de Peirce. Levando-se em conta que muito possivelmente ocorra o achatamento do fio na construção da estrutura do tecido, prefere-se levar em conta os valores calculados pelo modelo de Peirce para a realização dos cálculos do fator de cobertura dos tecidos.

Este procedimento ameniza a dificuldade em apurar uma medida precisa de diâmetro pois em geral, os fios têxteis apresentam características de maciez acentuada, são flexíveis, deformáveis e muito irregulares, apresentando grande variação de diâmetro ao longo de sua extensão (BEHERA; HARI, 2010). Isto também foi observado no presente estudo conforme mostrado na Figura 5.9.

\subsubsection{Fator de Cobertura}

Os valores de fator de cobertura, determinados para os tecidos adquiridos no mercado e dos uniformes, estão apresentados a seguir na Tabela 6.7. 
Tabela 6.7 - Valores de fator de cobertura determinados para os tecidos profissionais adquiridos no mercado e dos uniformes de aeronautas.

\begin{tabular}{c|cc}
\hline & & $\begin{array}{c}\text { Fator de } \\
\text { Cobertura }\end{array}$ \\
\hline T1 & Tecido profissional & 0,74 \\
T2 & Tecido profissional & 1,00 \\
T3 & Tecido profissional & 0,85 \\
P1 & Camisa fem. A & 0,69 \\
P2 & Camisa fem. A & 0,72 \\
P3 & Camisa masc. A & 0,86 \\
P4 & Camisa masc. B & 0,69 \\
P5 & Camisa masc. B & 0,70 \\
P6 & Paletó masc. B & 0,77 \\
P7 & Calça masc. B & 0,71 \\
P8 & Paletó masc. B & 0,75 \\
\hline
\end{tabular}

Fonte: Marcia Cristina Silva, 2018

Observa-se que pelos resultados da Tabela 6.7, os resultados dos fatores de cobertura foram todos semelhantes (ente 0,7 e 0,9). A única exceção ocorreu para T2 (Tecido leve, 67\% Poliéster e 33\% Algodão), cujo fator de cobertura resultou em 1,00. Quando é alcançada essa condição, onde para os fios de urdume e trama, o produto do número de fios por polegada e diâmetro de fios é igual a um, então os fios tocarão uns aos outros, e o fator de cobertura se torna igual a um (KASWELL, 1963). .

Quando essa condição existe para ambos conjuntos de fios, o fator de cobertura permanece um. Frequentemente, nesse último caso, o número máximo possível de fios de urdume e trama foram empregados na tecelagem para fabricação do tecido. Qualquer aumento posterior em tramas ou urdumes poderá resultar em fios amontoados uns sobre outros resultando em camadas duplas ou múltiplas de fios. Obviamente os fios podem ser compreensíveis e deste modo mais fios do que o máximo teórico, calculado em base de fios não comprimidos, são frequentemente presentes na tecelagem do tecido. $O$ fator de cobertura tem muita importância no que diz respeito à permeabilidade ao ar, vapor d'água (umidade) e água. Na contagem de fios do tecido, o grau de abertura poderá influenciar a penetração dentro ou através do tecido e, em parte, afetará a adesão entre fios (KASWELL, 1963). 


\subsection{ENSAIO DE INFLAMABILIDADE.}

\subsubsection{Validação do Sistema de Medição - Cabine USP}

- Método da Média e Amplitude

Foram separados oito lotes com três peças cada de T1 e submetidos ao ensaio de velocidade de queima da Cabine USP em duas ocasiões diferentes, nos dias 29 e 30 abril de 2018, no período das 9:00 - 12:00 horas. A temperatura ambiente estava entre $29^{\circ} \mathrm{C}$ e $31^{\circ} \mathrm{C}$ e a umidade relativa do ar entre 30 e $38 \%$ (WORLD WEATHER, 2018). Foram calculados os valores dos erros de repetibilidade (Equação 12), de reprodutibilidade (Equação 13) e erros totais (Equação 11).

Um sistema de medição é considerado adequado para o controle de uma característica da qualidade de uma peça e do processo quando a variação de erro total $(R \& R)$ é significativamente menor que a variação do processo, a qual é estimada pelo desvio padrão entre as peças (MONTGOMERY, 2009).

Neste estudo, o valor total do erro do sistema de medição de velocidade de queima ou variação total foi de 14,006 e o valor da R\&R é de 4,076 representando 29,10\% da variação total. A maior parte da variação foi proveniente das amostras e não do sistema de medição.

De acordo com os critérios de aceitação um sistema de medição com $R \& R$ contribuindo entre 10 e $30 \%$ pode ser aceito para algumas aplicações, considerando os riscos associados (WERKEMA, 2002). Deste modo, a variação do sistema de medição para a medição da velocidade de queima realizada na Cabine USP $(29,10 \%)$ é aceitável para condução dos ensaios de queima dos tecidos.

\subsubsection{Comparação velocidade de queima - Cabine UMINHO e Cabine USP}

Para efeito de comparação da velocidade de queima para tecidos iguais (T1 e T2) realizados nos dois equipamentos de ensaio de chamas, o mesmo teste de velocidade de queima foi realizado na cabine desenvolvida para os testes de chamas deste estudo (Cabine USP) e a característica com maior diferença foi o tamanho do corpo-de-prova, que neste caso é de 55x155 mm. Os resultados podem ser observados na Tabela 6.8. 
Tabela 6.8 - Valores de velocidade de queima $(\mathrm{cm} / \mathrm{s})$, determinados para dois tecidos adquiridos no mercado (T1 e T2) na Cabine UMINHO e Cabine USP. Os valores estão expressos em termos de média e desvio padrão de 10 medições e entre parênteses é indicado o coeficiente de variação.

Fonte: Marcia Cristina Silva, 2018

\section{Velocidade de queima}

\begin{tabular}{c|ccccc}
\hline & \multicolumn{3}{|c}{ Cabine UMINHO } & \multicolumn{2}{c}{ Cabine USP } \\
& & Trama & Urdume & Trama & Urdume \\
T1 & Tecido & $\mathbf{1 , 6 4} \pm 0,09$ & $\mathbf{1 , 6 5} \pm 0,18$ & $\mathbf{0 , 8 9} \pm 0,09$ & $\mathbf{0 , 9 1} \pm 10,16$ \\
& & $(5,21 \%)$ & $(10,65 \%)$ & $(10,09 \%)$ & $(11,20 \%)$ \\
T2 & Tecido & $\mathbf{2 , 0 3} \pm 0,26$ & $\mathbf{2 , 1 8} \pm 0,29$ & $\mathbf{2 , 8 8} \pm 0,14$ & $\mathbf{2 , 9 2} \pm 0,24$ \\
& & $(2,96 \%)$ & $(13,13 \%)$ & $(4,82 \%)$ & $(8,25 \%)$ \\
\hline
\end{tabular}

O fato dos resultados para o tecido T3 não terem sido considerados, pois quando se efetuaram os experimentos, a chama percorria o corpo-de-prova de forma lenta e devido ao comportamento termoplástico do material (100\% Poliéster), este começava a gotejar e a chama se apagava sem concluir o percurso determinado de $135 \mathrm{~mm}$, não sendo possível calcular a velocidade de queima.

Para os resultados de velocidade de queima dos tecidos T1 e T2 em experimentos realizados em ambas as cabines, realizou-se o teste de hipótese para comparação entre as médias de velocidade de queima. Para efetuar o Teste t de Student, é necessário primeiramente conhecer padrão de distribuição dos dados e a verificação da igualdade de variância das variáveis. A hipótese nula considera uma afirmação, ou seja, para o teste de normalidade o conjunto de dados da variável velocidade de queima apresenta distribuição normal e para o teste de igualdade de variâncias entre os equipamentos, apresentam a mesma variância. A decisão foi tomada no nível de significância de 5\% ( $p$-value $\geq 0,05$ ).

Para cada conjunto de 10 medidas em cada determinação foi realizado um teste de normalidade da distribuição dos dados. Para as medições de velocidade de queima realizadas nas duas cabines (UMINHO e USP), dos tecidos T1 e T2 na direção de trama e urdume, todos os testes de normalidade apresentam p-value maior que 0,05 caracterizando a distribuição normal dos dados.

Em seguida foram realizados os testes de igualdade de variância, para todos os conjuntos de medidas entre as duas cabines. Constatou-se que ocorreu igualdade de variâncias $(p>0,05)$ entre as duas cabines nas medições da velocidade de queima do tecido T1 e do tecido T2, na direção da trama e do urdume.

Confirmado que para os conjuntos de medidas entre as duas cabines de ensaio, houve condição de normalidade e igualdade de variâncias, foi possível realizar o Teste t de Student, para determinação de diferenças entre as médias. A hipótese nula estabelecida 
para este teste, considera igualdade das médias para um nível de significância de 5\%. Para os tecidos T1 e T2, na direção de trama e urdume foram apresentadas médias diferentes com $(p=0,00)$ para a velocidade de queima obtidas em ensaio realizados em cabines diferentes e desta forma refutando a hipótese nula.

Uma análise visual dos resultados para as observações da velocidade de queima realizadas nas Cabines UMINHO e USP está ilustrada nos Gráficos 3 e 4.

Gráfico 3 - Valores de velocidade de queima $(\mathrm{cm} / \mathrm{s})$ do Tecido T1 na Cabine UMINHO direção trama (azul) e direção urdume (vermelho) e Cabine USP.na direção da trama (verde) e na direção do urdume (amarelo). Os valores estão expressos em velocidade de queima para cada observação.

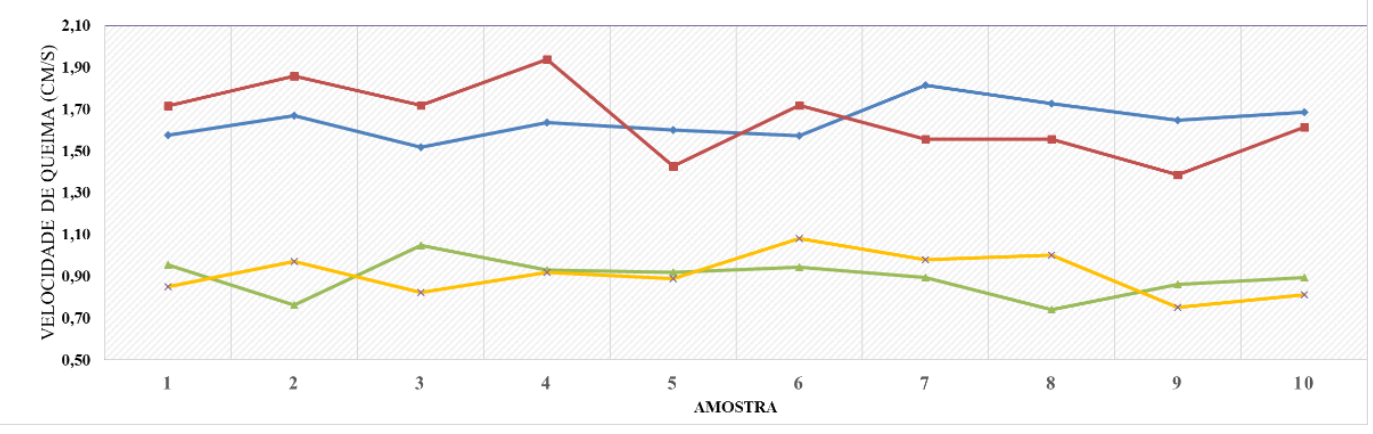

Fonte: Marcia Cristina Silva (2018)

Gráfico 4 - Valores de velocidade de queima $(\mathrm{cm} / \mathrm{s})$ do Tecido T2 na Cabine UMINHO direção trama (azul) e direção urdume (vermelho) e Cabine USP.na direção da trama (verde) e na direção do urdume (amarelo). Os valores estão expressos em velocidade de queima para cada observação.

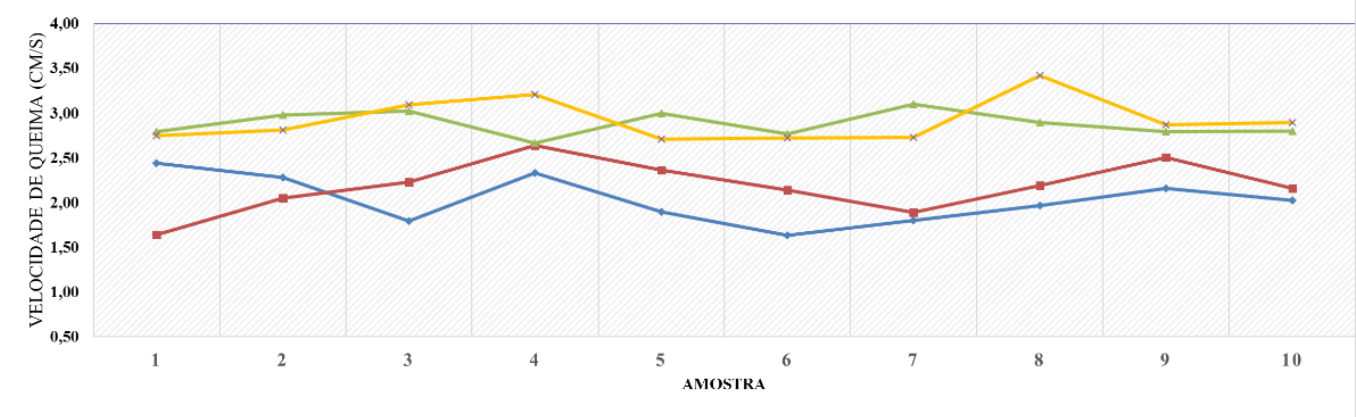

Fonte: Marcia Cristina Silva, 2018

Nos valores plotados na Gráfico 3, pode-se observar dois agrupamentos bem definidos em. Na parte inferior, as linhas verde e amarela representam a velocidade de queima do Tecido T1 na Cabine USP na direção da trama e do urdume respectivamente. Na parte superior as linhas azul e vermelha apresentam a velocidade de queima do Tecido 1 na Cabine UMINHO na direção da trama e do urdume.

Entretanto para o Tecido T2, cujos resultados são plotados na Gráfico 4 os agrupamentos dos valores de velocidade de queimas realizados nas Cabine UMINHO e 
Cabine USP não apresentam distanciamento claro de suas faixas de valores, corroborando com a norma ISO 6940:2004, para a qual a precisão do teste de chamas dependente para o tipo de material a ser testado.

As taxas de propagação de chamas não são constantes, pois após a ignição há um período de aumento de intensidade e aceleração das chamas e a precisão do teste depende muito do material a ser testado. Somente se a chama se espalhar por toda a largura útil do corpo-de-prova, a taxa de propagação torna-se ligeiramente constante. Também, as taxas calculadas de propagação da chama, não são reproduzíveis, conforme demonstrados por testes realizados entre onze laboratórios em 1993, o qual apresentou diferenças de até $20 \%$ no tempo percorrido pelas chamas até a linha no limite superior (INTERNATIONAL ORGANIZATION FOR STANDARDIZATION, 2004).

Em continuidade a comparação entre as Cabines de Teste de inflamabilidade, realizou-se a análise do coeficiente de correlação de Pearson, cuja medida representa a associação linear entre as variáveis resposta. Os coeficientes de Pearson variam de -1 a +1, ou seja, quanto mais próximo de 1, maior será a força de relação entre as variáveis.

Para o Tecido T1 direção da trama, o coeficiente de Pearson foi de 0,641 e para o urdume foi de 0,364 . Para o Tecido T2, o coeficiente de Pearson para a trama foi de 0,432 e para o urdume foi de 0,416 .

Deste modo se conclui que os equipamentos de ensaio (Cabine UMINHO e Cabine USP) fornecem valores de velocidade de queima com diferenças estatisticamente significativas, ou seja, pode se entender que os valores diferem significativamente entre si, porém existe uma correlação moderada entre eles.

As considerações sobre a diferença entre os valores de velocidade de queima obtidos nos dois equipamentos de teste apontam para as possíveis variáveis : (i)Tamanho da amostra, que para a Cabine UMINHO, o corpo de prova é maior, contribuído para a alimentação das chamas com a massa de material combustível; (ii) Volume de ar na cabine, pois existe uma diferença dimensional das cabines, podendo armazenar volume maior de oxigênio disponível dentro da Cabine UMINHO durante o ensaio, atuando como comburente e (iii) Cronometragem, pois existe uma diferença entre o início e a finalização da contagem de tempo. Na Cabine USP a atuação do cronômetro é feita de forma automática, evitando os erros pela ação humana.

Ressalta-se que para a realização dos testes de queima proposto para o presente trabalho, totalizando mais de duzentas operações, foi necessário o desenvolvimento de uma cabine de ensaio para atender as limitações dimensionais dos corpos-de-prova 
retirados de peças de uniformes e a quantidade de amostras necessária para gerar os dados para análise estatística.

\subsubsection{Velocidade de Queima dos Tecidos dos Uniformes dos Aeronautas na cabine USP.}

Cumpre recordar que não foi possível realizar os testes de inflamabilidade dos tecidos dos uniformes de aeronautas na Cabine UMINHO, em virtude da pequena disponibilidade de tecidos desses uniformes frente a grande dimensão das amostras requeridas para a realização de cada um dos testes naquela cabine.

Para a Cabine USP, os valores de velocidade de queima, determinados para os tecidos adquiridos no mercado (T1 a T3) e das peças de uniformes (P1 a P8) conforme o Item 5.3.8 e estão apresentados a seguir na Tabela 6.9.

Tabela 6.9 - Valores de velocidade de queima em $\mathrm{cm} / \mathrm{s}$, determinados para dois tecidos adquiridos no mercado (T1 e T2) e peças de uniformes (P1 a P8) na Cabine USP, nos sentidos de trama e urdume. Os valores estão expressos em termos de média e desvio padrão de 10 medições e entre parênteses é indicado o coeficiente de variação.

\begin{tabular}{|c|c|c|c|}
\hline \multicolumn{3}{|r|}{ Trama } & Urdume \\
\hline T1 & Tecido & $\begin{array}{c}\mathbf{0 , 9 7 9} \pm 0,09 \\
(10,50 \%)\end{array}$ & $\begin{array}{c}\mathbf{1 , 0 2 8} \pm 0,088 \\
(11,68 \%)\end{array}$ \\
\hline $\mathbf{T} 2$ & Tecido & $\begin{array}{c}\mathbf{2 , 8 7 8} \pm 0,138 \\
(4,82 \%)\end{array}$ & $\begin{array}{c}\mathbf{2 , 9 2 0} \pm 0,241 \\
(8,25 \%)\end{array}$ \\
\hline P1 & Camisa fem. A & $\begin{array}{c}\mathbf{2 , 6 5} \pm 0,2651 \\
(10,00 \%)\end{array}$ & $\begin{array}{c}\mathbf{1 , 6 4} \pm 0,285 \\
(17,33 \%)\end{array}$ \\
\hline P2 & Camisa fem. A & $\begin{array}{c}\mathbf{2 , 8 9 1} \pm 0,514 \\
(12,06 \%)\end{array}$ & $\begin{array}{c}\mathbf{3 , 8 2 7} \pm 0,462 \\
(17,79 \%)\end{array}$ \\
\hline P3 & Camisa masc. A & $\begin{array}{c}\mathbf{1 , 3 4 0} \pm 0,116 \\
(8,69 \%)\end{array}$ & $\begin{array}{c}\mathbf{1 , 4 1 0} \pm 0,070 \\
(5,03 \%)\end{array}$ \\
\hline P4 & Camisa masc. B & $\begin{array}{c}\mathbf{3 , 0 2 2} \pm 0,263 \\
(8,72 \%)\end{array}$ & $\begin{array}{c}\mathbf{3 , 5 1 3} \pm 0,418 \\
(11,91 \%)\end{array}$ \\
\hline P5 & Camisa masc. B & $\begin{array}{c}\mathbf{3 , 6 9 8} \pm 1,806 \\
(48,83 \%)\end{array}$ & $\begin{array}{c}\mathbf{3 , 1 3 0} \pm 0,493 \\
(15,92 \%)\end{array}$ \\
\hline P6 & Paletó masc. B & $\begin{array}{c}\mathbf{0 , 9 7 2} \pm 0,114 \\
(11,78 \%)\end{array}$ & $\begin{array}{c}\mathbf{0 , 9 7 9} \pm 0,130 \\
(10,52 \%)\end{array}$ \\
\hline P7 & Calça masc. B & $\begin{array}{c}\mathbf{0 , 7 4 2} \pm 0,140 \\
(18,92 \%)\end{array}$ & $\begin{array}{c}\mathbf{0 , 9 3 4} \pm 0,080 \\
(8,64 \%)\end{array}$ \\
\hline P8 & Paletó masc. B & $\begin{array}{c}\mathbf{0 , 9 9 4} \pm 0,121 \\
(12,19 \%)\end{array}$ & $\begin{array}{c}\mathbf{1 , 0 3 0} \pm 0,10 \\
(10,29 \%)\end{array}$ \\
\hline
\end{tabular}

Fonte: Marcia Cristina Silva, 2018

Para os tecidos avaliados no teste de inflamabilidade o menor valor encontrado foi de média de $\mathbf{0 , 7 4 2} \pm 0,140(\mathrm{~cm} / \mathrm{s})$. Este resultado trata-se da média obtida da velocidade de queima das 10 amostras ensaiadas do tecido da peça P7 (calça masculina) na direção da trama. A composição da peça é uma mistura de lã e poliéster com gramatura de 
$\mathbf{2 2 5 , 1 2 \pm 5 , 0 2}\left(\mathrm{g} / \mathrm{m}^{2}\right)$, densidade linear do fio de $\mathbf{3 6 , 6 1} \pm 1,48$ (tex) e torção de $\mathbf{5 9 8 , 0 0 \pm 4 5 , 3 4 ( t o r c ̧ o ̃ e s / m ) . ~ O ~ d i a ̂ m e t r o ~ d o ~ f i o ~ c a l c u l a d o ~ p e l o ~ m o d e l o ~ d e ~ P e i r c e ~ e ́ ~ d e ~} \mathbf{0 , 2 1 9}$ $\mathrm{mm}$.

No outro extremo menor valor encontrado foi de média de $\mathbf{3 , 6 9 8} \pm 1,806(\mathrm{~cm} / \mathrm{s})$. Este resultado trata-se da média obtida da velocidade de queima das 10 amostras ensaiadas do tecido da peça P5 (camisa masculina) na direção da trama. A composição da peça é uma mistura de poliéster e algodão com gramatura de $\mathbf{1 0 8 , 7 2 \pm 2 , 3 9}\left(\mathrm{g} / \mathrm{m}^{2}\right)$,

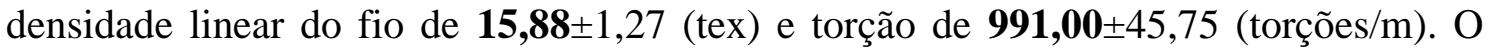
diâmetro do fio calculado pelo modelo de Peirce é de $0,148 \mathrm{~mm}$.

\subsection{ANÁLISE DE ESTATÍSTICA}

Para a análise estatísticas foram utilizados os softwares o software Minitab (Minitab Inc. versão 18 -2017), disponível para alunos de pós-graduação no Sistema de Download de Software Institucional da Superintendência de Tecnologia da Informação da USP e Software Action Stat, versão de avaliação 3.5.152.34, versão do R: 3.3 .2 (disponível publicamente no site www.portalaction.com.br).

As seguintes análises de dados foram realizadas em ambos os softwares de maneira a garantir a confiabilidade e reprodutibilidade dos resultados obtidos, sendo estas (HAIR, 2010):

- ANOVA

- Teste de Normalidade dos dados e dos resíduos (Anderson Darling- AD, Kolmogorov-Smirnov - KS, Shapiro-Wilk - SW)

- Teste de igualdade de Variâncias (Levene, Teste F, Bonnet, Bartlet)

- Teste t de student para igualdade de médias

- Teste de múltiplas comparações de Hsu

- Teste não paramétrico Kruskall Wallis

\subsubsection{Análise das variáveis}

A velocidade de queima dos tecidos representa a variável resposta.

No intuito de avaliar a importância dos fatores estudados, foi realizada inicialmente a análise de variância (ANOVA), a qual testa a hipótese de que as médias de duas ou mais populações sejam iguais. 
Para que os resultados da ANOVA sejam válidos é necessário que:

- Os desvios padrões das distribuições dos valores da variável resposta (velocidade de queima) dos grupos têm que ser iguais, configurando a homocedasticidade.

- A distribuição dos valores da variável resposta (velocidade de queima) de cada grupo deve ser normal.

O teste de hipótese para comparação entre as médias de velocidade de queima (variável resposta) em relação às variáveis explicativas (composição, ligamento, direção, gramatura, espessura, diâmetro do fio e densidade linear) foi o ANOVA one way ou análise de variância de um fator. A hipótese nula considera uma afirmação, ou seja, para a análise de variância, a média de velocidade de queima é igual para todos os fatores (variáveis explicativas). O nível de significância empregado na análise foi de 5\% (p-value $\geq 0,05)$ e os valores de $\mathrm{p}$-value calculados estão relacionados na Tabela 6.10.

Tabela 6. 10 - ANOVA - variável resposta "velocidade de queima" com relação as variáveis explicativas "fios de trama", "fios de urdume", "fator de cobertura", "torção", "gramatura", "espessura", "diâmetro do fio" e "densidade" .

\begin{tabular}{c|ccccc}
\hline Fonte & $\begin{array}{c}\text { Graus de } \\
\text { Liberdade }\end{array}$ & $\begin{array}{c}\text { Soma dos } \\
\text { Quadrados }\end{array}$ & $\begin{array}{c}\text { Quadrado } \\
\text { Médio }\end{array}$ & $\begin{array}{c}\text { Estatística } \\
\text { F }\end{array}$ & $\begin{array}{c}\text { P- } \\
\text { Value }\end{array}$ \\
\hline Variáveis & 7 & 52.140 .992 & 7.448 .713 & 420,02 & $\mathbf{0 , 0 0 0}$ \\
Erro & 1.592 & 28.232 .912 & 17.734 & & \\
Total & 1.599 & 80.373 .904 & & & \\
\hline
\end{tabular}

Fonte: Marcia Cristina Silva, 2018

$\mathrm{O}$ valor de $\mathrm{p}$ ( $\mathrm{p}$-value) menor que 0,05 a hipótese nula é rejeitada, indicando que pelo menos uma das médias é diferente.

Para validação da análise foi realizada a verificação dos resíduos da ANOVA, os quais não apresentaram distribuição normal e também não possuem igualdade de variância.

Não sendo possível possível validar a ANOVA one way com todos os fatores (variáveis explicativas) indicadas na Tabela 6.10, uma vez que os resíduos não atendem as premissas de distribuição normal e igualdade de variância, optou-se por analisar a relação de três variáveis explicativas ("direção", "material”, "ligamento”) com a variável resposta "velocidade de queima", por meio de agrupamento dos resultados originados dos testes físicos realizados nos tecidos com afinidades específicas, ou seja especificações técnicas semelhantes. 
Primeiro, os resultados foram agrupados por tipo de "material" (100\% CO, 100\% PES, 67\%PES/33\% CO e 50\% WO/50\%PES) e "ligamento" (tela e sarja) e verificada a hipótese de igualdade de médias da variável resposta "velocidade de queima" com relação à variável explicativa "direção" (trama e urdume).

Em seguida, os resultados foram agrupados por tipo de "ligamento" (tela e sarja) e direção (trama e urdume) e verificada a hipótese de igualdade de médias da variável resposta "velocidade de queima" com relação à variável explicativa "material" $(100 \%$ CO, 100\%PES e 67\%PES/33\%CO).

\subsubsection{Influência da variável "direção" (trama e urdume) na variável resposta "velocidade de queima".}

Os resultados foram agrupados por tipo de "material" (100\% CO, 100\% PES, 67\%PES/33\% CO e 50\% WO/50\%PES) e "ligamento" (tela e sarja) e verificada a hipótese de igualdade de médias da variável resposta "velocidade de queima" com relação à variável explicativa “direção" (trama e urdume).

O nível de significância para tomada de decisão é $\alpha=0,05$ ou seja, para aceitar a hipótese nula é necessário um valor de p (p-value) maior que 0,05.

Considerando que para cada grupo de resultados há somente 10 valores (amostragem considerada pequena), além da ANOVA foi realizado comparativamente o Teste t de Student nos casos onde haviam somente dois grupos a serem analisados.

\subsubsection{ANOVA - variável resposta "velocidade de queima" com relação a variável explicativa "direção" para o grupo "material algodão $(100 \% \mathrm{CO})$ e ligamento sarja”.}

Os resultados obtidos na ANOVA estão descritos na Tabela 6.11.

Tabela 6. 11 - ANOVA - variável resposta "velocidade de queima" com relação a variável explicativa "direção" entre grupos de material "algodão $(100 \% \mathrm{CO})$ e ligamento sarja"

\begin{tabular}{c|ccccc}
\hline Fonte & $\begin{array}{c}\text { Graus de } \\
\text { Liberdade }\end{array}$ & $\begin{array}{c}\text { Soma dos } \\
\text { Quadrados }\end{array}$ & $\begin{array}{c}\text { Quadrado } \\
\text { Médio }\end{array}$ & $\begin{array}{c}\text { Estatística } \\
\text { F }\end{array}$ & $\begin{array}{c}\text { P- } \\
\text { Value }\end{array}$ \\
\hline Direção & 1 & 0,000778 & 0,000778 & 0,08 & $\mathbf{0 , 7 7 5}$ \\
Erro & 18 & 0,166394 & 0,009244 & & \\
Total & 19 & 0,167172 & & & \\
\hline
\end{tabular}

Fonte: Marcia Cristina Silva, 2018 
Para valor de p (p-value) maior que 0,05 a hipótese nula é aceita, indicando que que as médias para velocidade de queima do grupo a são estatisticamente iguais.

A Figura 33(a) mostra os valores de médias para "velocidade de queima" em relação à "direção" e a Figura 33(b), esses mesmos valores de médias com seus respectivos intervalos de confiança $95 \%$.

Figura 33 - Médias da variável resposta "velocidade de queima" com relação a variável explicativa "direção" no grupo de material "algodão $(100 \% \mathrm{CO})$ e ligamento sarja":(a) Gráfico de efeitos; (b)Médias com respectivos de intervalos de confiança (95\%).

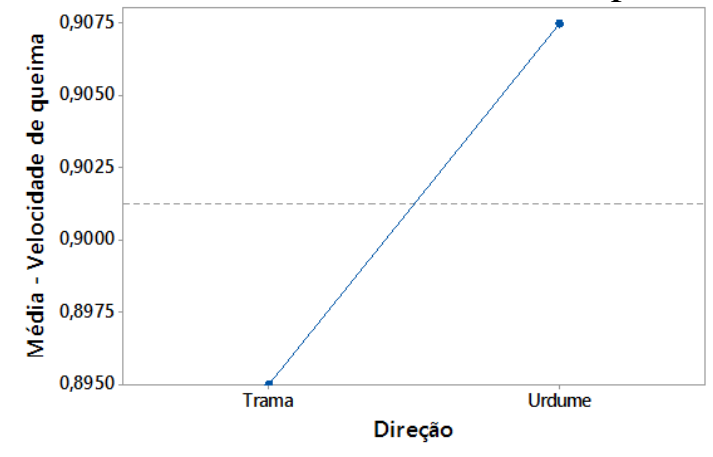

(a)

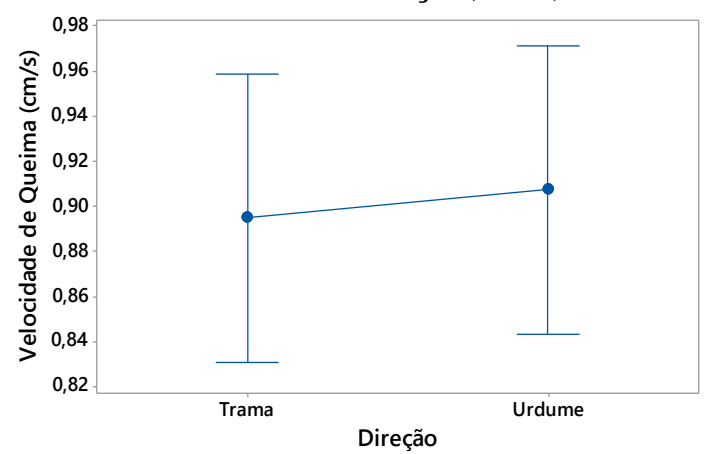

(b)

Fonte: Marcia Cristina Silva, 2018

Apesar da ANOVA demonstrar que as médias são estatisticamente iguais, na Figura 33(a), pode ser observado uma tendência, na qual velocidade de queima é ligeiramente maior na direção do urdume. Isto pode ser explicado pelo número maior de fios na direção do urdume conforme Tabela 6.3. A Figura 33(b) demonstra a sobreposição dos das faixas de médias com intervalos de confiança para trama e urdume, confirmando que as médias de velocidade de queima são estatisticamente iguais.

Para validação da análise foi realizada a verificação dos resíduos da ANOVA, conforme ilustrado na Figura 33(a) a (d). 
Figura 34 - Resultados da análise dos resíduos da ANOVA relacionando a variável resposta "velocidade de queima" com a variável explicativa "direção" para o grupo de dados relativos ao "material algodão $(100 \% \mathrm{CO})$, ligamento sarja": (a) Histograma dos resíduos; (b) Papel de probabilidade; (c) Resíduos por valores ajustados; (d) Resíduos por Ordem de coleta.

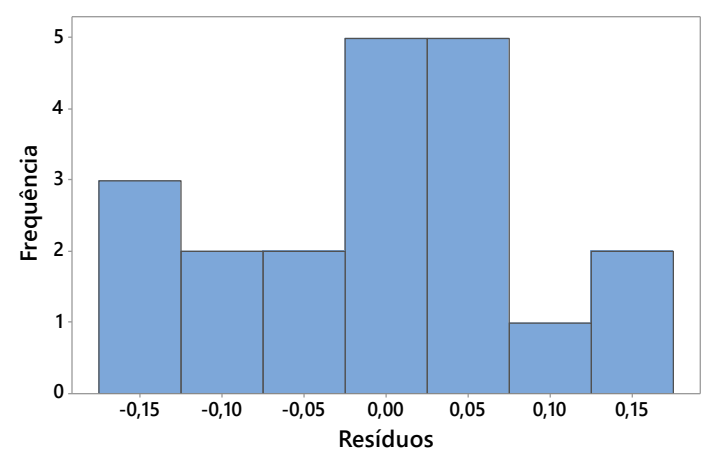

(a)

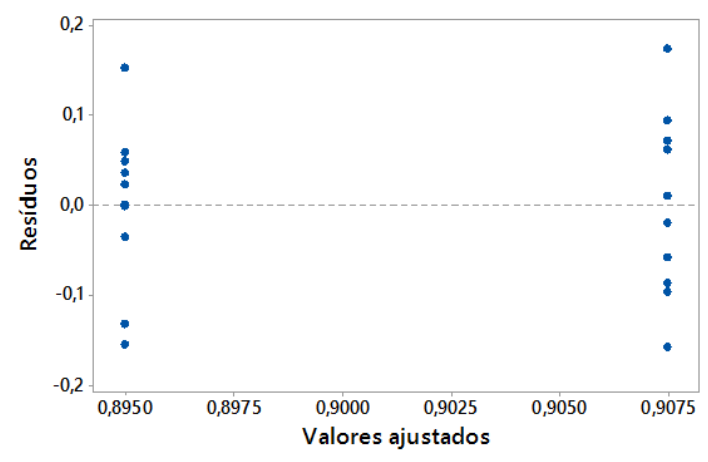

(c)

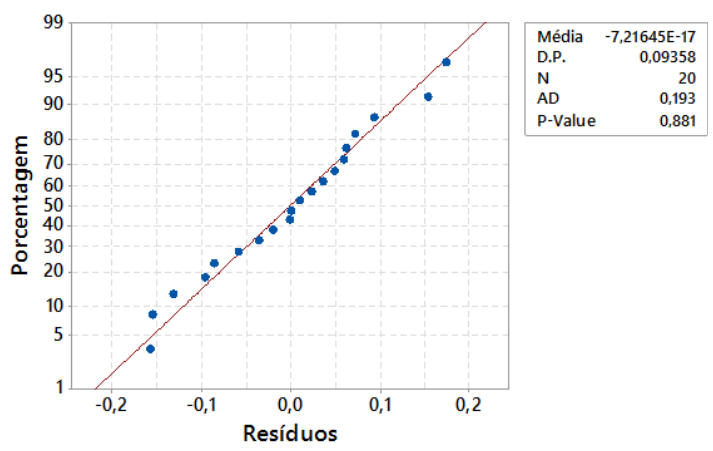

(b)

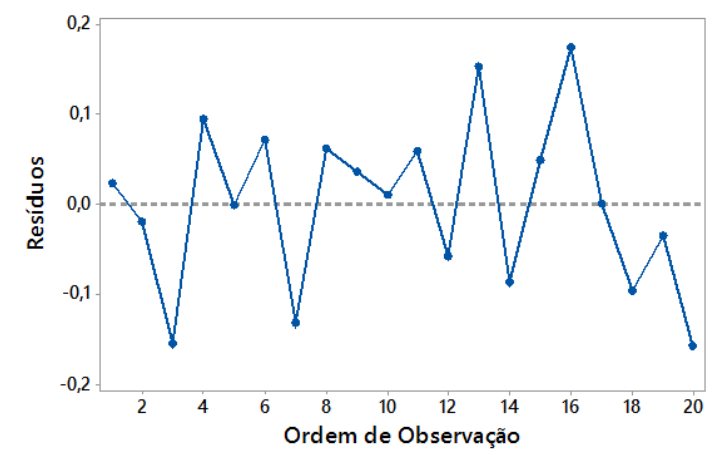

(d)

Fonte: Marcia Cristina Silva, 2018

O histograma (Figura 36(a)) e o papel de probabilidade (Figura 36(b)) demonstram a dispersão e distribuição dos resíduos e juntamente com teste de normalidade Anderson-Darling com valor de $\mathrm{p}$ ( $\mathrm{p}$-value) igual a 0,881. Para valor de $\mathrm{p}$ (p-value) maior que 0,05 a hipótese nula é aceita, indicando que os resíduos apresentam distribuição normal.

A Figura 36(c) demonstra graficamente que a variância dos resíduos apresenta igualdade. Também foi possível verificar a independência dos resíduos (Figura 36(d)), não apresentando comportamento sistemático, sem indício de influência externa ao experimento.

Para a confirmação de que os resíduos apresentam igualdade de variância foi realizado o teste de igualdade de variância Bartlet, resultando em valor de p (p-value) igual a 0,731. Para valor de p (p-value) maior que 0,05 a hipótese nula é aceita, indicando 
que os resíduos apresentam igualdade de variância. Também foi possível ilustrar tal igualdade graficamente, conforme demonstrado na Figura 35.

Figura 35 - Teste de Bartlett para Análise de Variância dos resíduos relacionando a variável resposta "velocidade de queima" com a variável explicativa "direção" no grupo de dados relativos ao "material algodão $(100 \% \mathrm{CO})$, ligamento sarja":

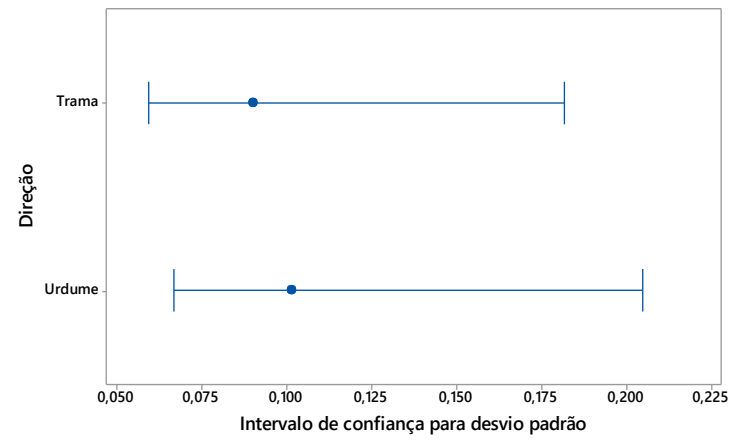

Fonte: Marcia Cristina Silva, 2018

Na Figura 35, é possível verificar a sobreposição das médias dos resíduos com os respectivos intervalos de confiança, confirmando a igualdade de variância dos resíduos.

A análise dos resíduos, juntamente com a ANOVA com valor de $\mathrm{p}$ (p-value) maior que 0,05 a hipótese nula é aceita e confirma a hipótese de igualdade das médias da variável "velocidade de queima" para o grupo de "material algodão (100\%CO), ligamento sarja" na direção de trama e urdume.

\subsubsection{ANOVA - variável resposta "velocidade de queima" com relação a variável explicativa "direção" no grupo " material poliéster (100\% PES) e ligamento sarja”.}

Os resultados obtidos na ANOVA estão descritos na Tabela 6.12.

Tabela 6. 12 - ANOVA - variável resposta "velocidade de queima" com relação a variável explicativa "direção" entre grupos de material "poliéster (100\% PES) e ligamento sarja"

\begin{tabular}{cccccc}
\hline \multicolumn{5}{c}{ Análise de Variância } \\
\hline Fonte & Graus de & Soma dos & Quadrado & Estatística F & P-Value \\
& Liberdade & Quadrados & Médio & & \\
Direção & 1 & 5,068 & 5,068 & 66,83 & $\mathbf{0 , 0 0 0}$ \\
Erro & 18 & 1,365 & 0,075 & & \\
Total & 19 & 6,434 & & & \\
\hline \multicolumn{5}{r}{ Fonte: Marcia Cristina Silva, 2018 }
\end{tabular}


Para valor de $\mathrm{p}$ (p-value) menor que 0,05 a hipótese nula é rejeitada, indicando que as médias para velocidade de queima do grupo a são estatisticamente diferentes.

$\mathrm{O}$ valor de $\mathrm{p}$ (p-value) menor que 0,05 demonstra que as médias para velocidade de queima são estatisticamente diferentes. A Figura 36(a) e (b) demostra os valores de média para velocidade de queima e o intervalo de confiança.

Figura 36 - Médias da variável resposta "velocidade de queima" com relação a variável explicativa "direção" para grupo de material "poliéster (100\% PES) e ligamento sarja": (a) Gráfico de efeitos; (b) Médias com respectivos de intervalos de confiança (95\%).

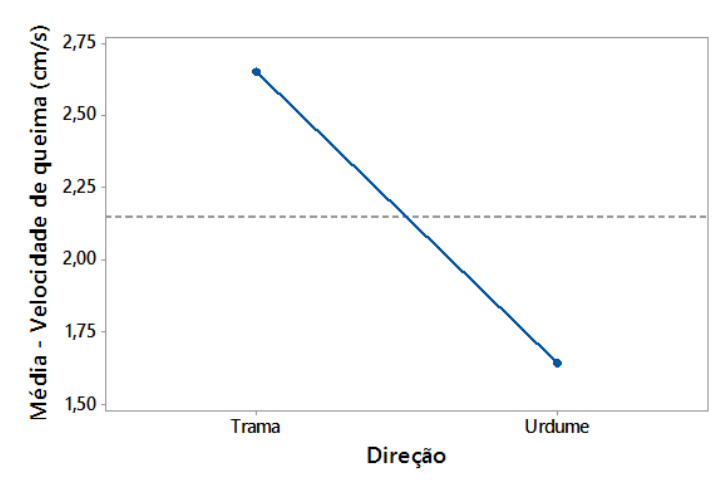

(a)

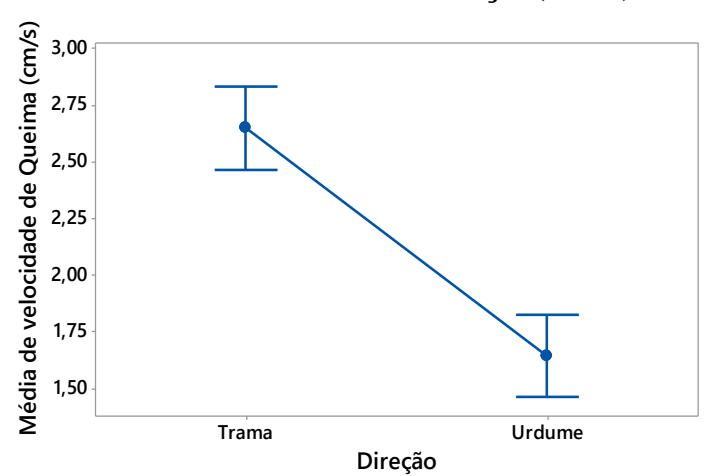

(b)

Fonte: Marcia Cristina Silva, 2018

Na Figura 36(a), pode ser observado que a velocidade de queima é maior na direção da trama. Associado a este fato, o valor de p (p-value) igual a 0,000 e a Figura 36(b) demonstra que não há sobreposição dos intervalos de confiança de trama e urdume, confirmando que as médias de velocidade de queima são estatisticamente diferentes. Para validação da análise foi realizada a verificação dos resíduos, conforme ilustrado na Figura 37(a) a (d). 
Figura 37 - Resultados da análise dos resíduos da ANOVA relacionando a variável resposta "velocidade de queima" com a variável explicativa "direção" no grupo de dados relativos ao "material poliéster (100\%PES) com ligamento sarja": (a) Histograma dos resíduos; (b) Papel de probabilidade; (c) Resíduos por valores ajustados; (d) Resíduos por Ordem de coleta.

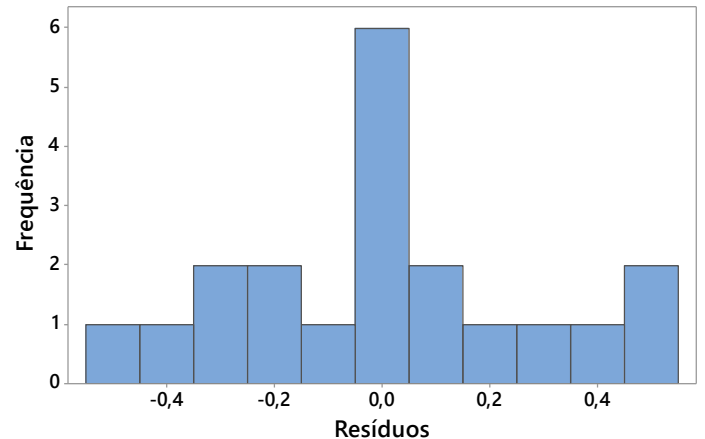

(a)

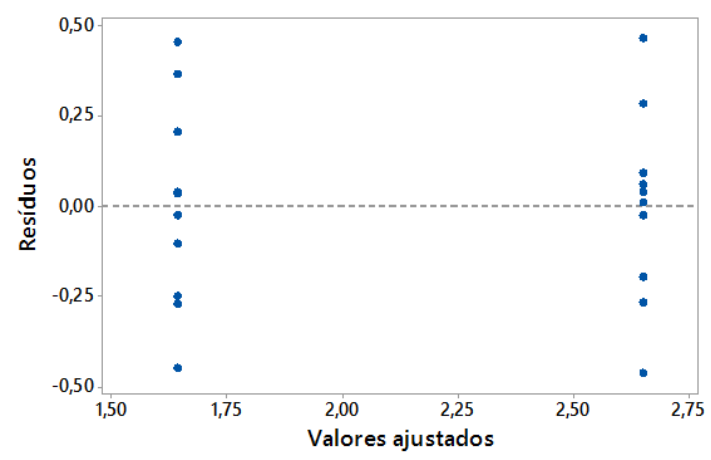

(c)

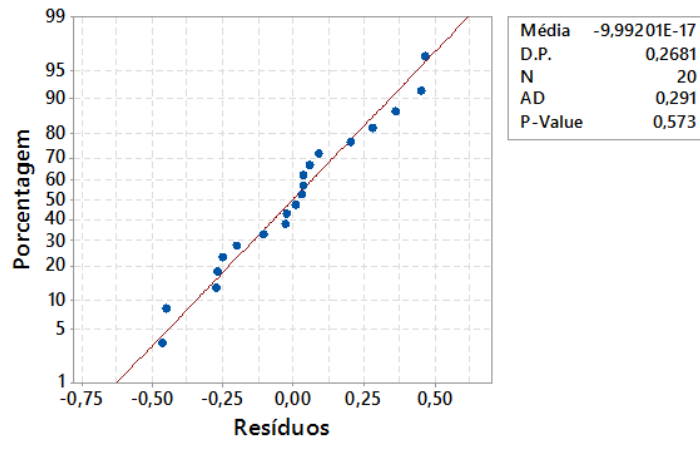

(b)

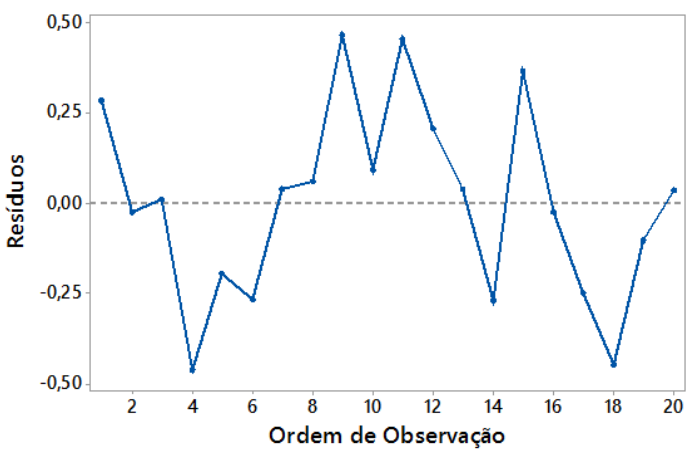

(d)

Fonte: Marcia Cristina Silva, 2018

O histograma (Figura 37(a)) e o papel de probabilidade (Figura 40(b)) demonstram a dispersão e distribuição dos resíduos e juntamente com teste de normalidade Anderson-Darling com valor de p (p-value) igual a 0,573. Para valor de $\mathrm{p}$ (p-value) maior que 0,05 a hipótese nula é aceita, indicando que os resíduos apresentam distribuição normal.

A Figura 37(c) demonstra graficamente que a variância dos resíduos apresenta igualdade. Também foi possível verificar a independência dos resíduos (Figura 37(d)), não apresentando comportamento sistemático, sem indício de influência externa ao experimento.

Para a confirmação de que os resíduos apresentam igualdade de variância foi realizado o teste de igualdade de variâncias de Bartlet valor de p (p-value) igual a 0,832. 
Para valor de p (p-value) maior que 0,05 a hipótese nula é aceita, indicando que os resíduos apresentam igualdade de variância. Também foi possível ilustrar tal igualdade graficamente, conforme demonstrado na Figura 38.

Figura 38 - Teste de Bartlett para Análise de Variância dos resíduos relacionando a variável resposta "velocidade de queima" com a variável explicativa "direção" no grupo de dados relativos ao "material poliéster (100\%PES) com ligamento sarja":

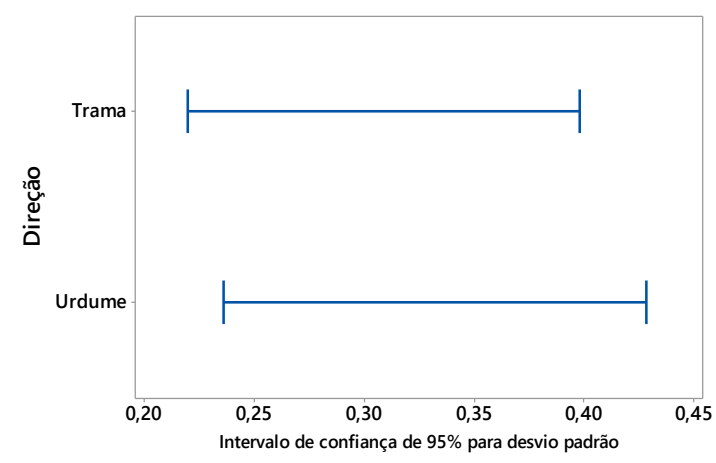

Fonte: Marcia Cristina Silva, 2018.

Na Figura 38, é possível verificar a sobreposição dos intervalos de confiança, confirmando a igualdade de variância dos resíduos. A análise dos resíduos, juntamente com a ANOVA com valor de p (p-value) menor que 0,05 a hipótese nula é rejeitada em favor da hipótese alternativa de que as médias da variável resposta "velocidade de queima" relacionada com a variável explicativa "direção" no grupo de dados relativos ao "material poliéster (100\%PES) com ligamento sarja" são estatisticamente diferentes.

Para determinação do melhor tratamento, o qual para este estudo trata-se daquele que apresenta menor média para velocidade de queima, foi realizado o teste de múltiplas comparações com o melhor, proposto por Hsu. O resultado na Figura 39.

Figura 39 - Teste de múltiplas comparações de Hsu relacionando a variável resposta "velocidade de queima" com a variável explicativa "direção" no grupo de dados relativos ao "material poliéster (100\%PES) com ligamento sarja":

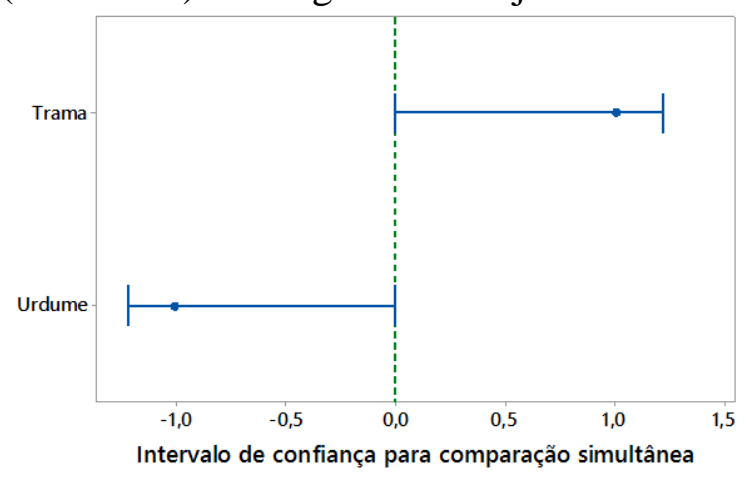

Fonte: Marcia Cristina Silva, 2018. 
O intervalo de confiança criado pelo teste de Hsu, o qual demonstra a diferença entre cada média de velocidade de queima com a melhor das médias, apresentam intervalos com zero como ponto final, evidenciando que existe uma diferença estatisticamente significativa entre as médias correspondentes. O intervalo de confiança referente ao urdume possui grande parte dos valores negativos, portanto, pode-se dizer que ele é o melhor entre os demais.

\subsubsection{ANOVA - variável resposta "velocidade de queima" com relação a variável explicativa "direção" para grupo "material poliéster (100\% PES) e ligamento tela".}

Os resultados obtidos na ANOVA estão descritos na Tabela 6.13.

Tabela 6. 13 - ANOVA - variável resposta "velocidade de queima" com relação a variável explicativa "direção" para o grupo "material poliéster (100\% PES) e ligamento tela"

\begin{tabular}{cccccc}
\hline \multicolumn{5}{c}{ Análise de Variância } \\
\hline Fonte & Graus de & Soma dos Quadrados & Quadrado & Estatística F & P-Value \\
& Liberdade & & Médio & & \\
Direção & 1 & 4,383 & 4,3829 & 18,34 & $\mathbf{0 , 0 0 0}$ \\
Erro & 18 & 4,301 & 0,2385 & & \\
Total & 19 & 8,684 & & & \\
\hline
\end{tabular}

Fonte: Marcia Cristina Silva, 2018

$\mathrm{O}$ valor de $\mathrm{p}$ ( $\mathrm{p}$-value) menor que 0,05 demonstra que as médias para velocidade de queima são estatisticamente diferentes. A Figura 40(a) e (b) demostra os valores de média para velocidade de queima e o intervalo de confiança.

Figura 40 - Médias da variável resposta "velocidade de queima" com relação a variável explicativa "direção" para o grupo de material "poliéster (100\% PES) e ligamento tela":

(a) Gráfico de efeitos; (b) Médias com respectivos de intervalos de confiança (95\%).

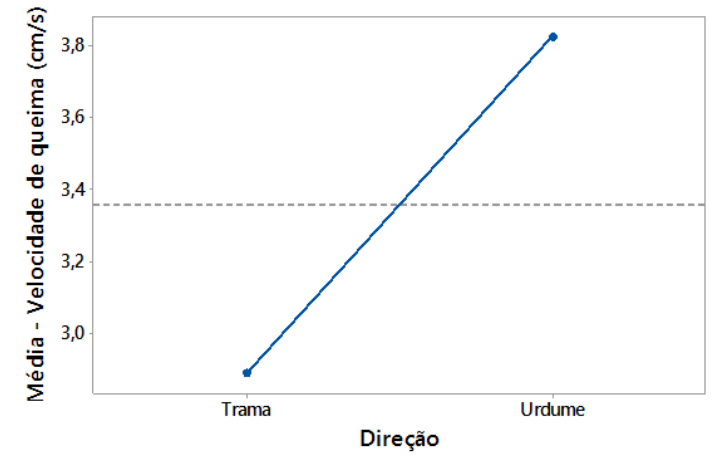

(a)

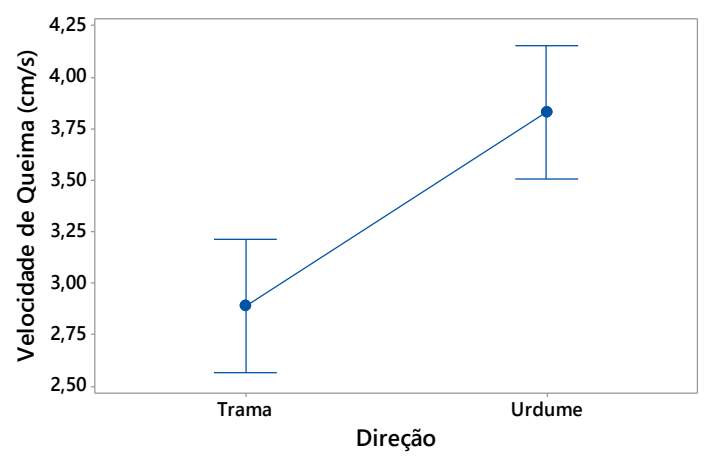

(b)

Fonte: Marcia Cristina Silva, 2018 
Na Figura 40(a), pode ser observado que a velocidade de queima é maior na direção da trama. Associado a este fato, o valor de p (p-value) igual a 0,000 e a Figura 40(b) demonstra que não há sobreposição dos intervalos de confiança de trama e urdume, confirmando que as médias de velocidade de queima são estatisticamente diferentes. Para validação da análise foi realizada a verificação dos resíduos, conforme ilustrado na Figura 41(a) a (d).

Figura 41 - Resultados da análise dos resíduos da ANOVA relacionando a variável resposta "velocidade de queima" com a variável explicativa "direção" no grupo de dados relativos ao "material poliéster (100\%PES) com ligamento tela": (a) Histograma dos resíduos; (b) Papel de probabilidade; (c) Resíduos por valores ajustados; (d) Resíduos por Ordem de coleta.

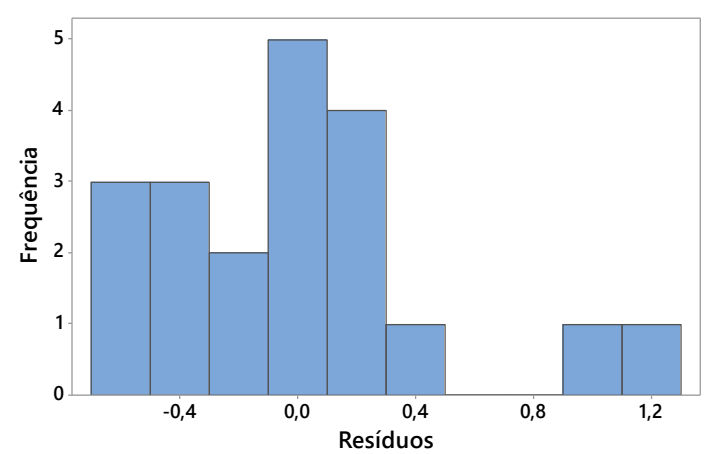

(a)

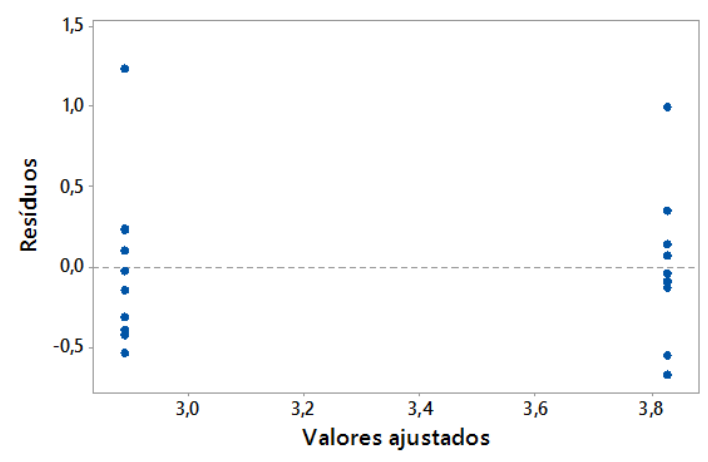

(c)

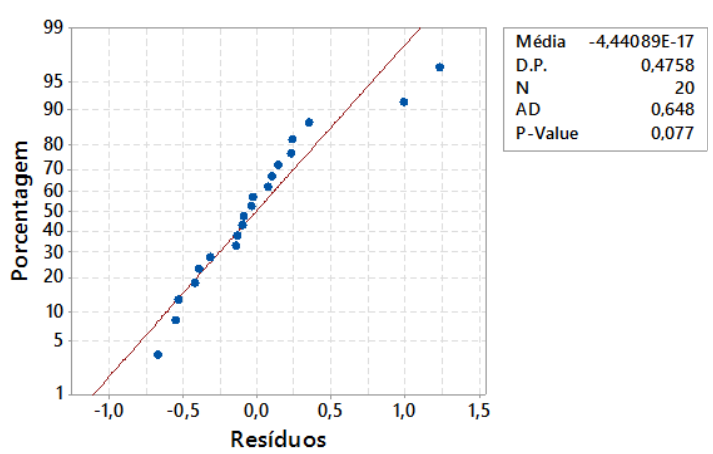

(b)

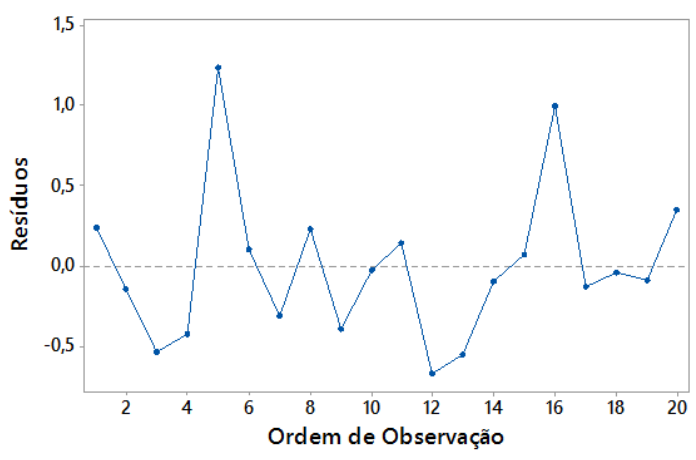

(d)

Fonte: Marcia Cristina Silva, 2018

O histograma (Figura 41(a)) e o papel de probabilidade (Figura 41(b)) demonstram a dispersão e distribuição dos resíduos e juntamente com teste de normalidade Anderson-Darling com valor de $\mathrm{p}$ ( $\mathrm{p}$-value) igual a 0,077. Para valor de $\mathrm{p}$ (p-value) maior que 0,05 a hipótese nula é aceita, indicando que os resíduos apresentam distribuição normal. 
A Figura 41(c) demonstra graficamente que a variância dos resíduos apresenta igualdade. Também foi possível verificar a independência dos resíduos (Figura 41(d)), não apresentando comportamento sistemático, sem indício de influência externa ao experimento.

Para a confirmação de que os resíduos apresentam igualdade de variância foi realizado o teste de igualdade de variância Bartlet, resultando em valor de p (p-value) igual a 0,753. Para valor de p (p-value) maior que 0,05 a hipótese nula é aceita, indicando que os resíduos apresentam igualdade de variância. Também foi possível ilustrar tal igualdade graficamente, conforme demonstrado na Figura 46.

Figura 42 - Teste de Bartlet para Análise de Variância dos resíduos relacionando a variável resposta "velocidade de queima" com a variável explicativa "direção" no grupo de dados relativos ao "material poliéster (100\%PES) com ligamento tela":

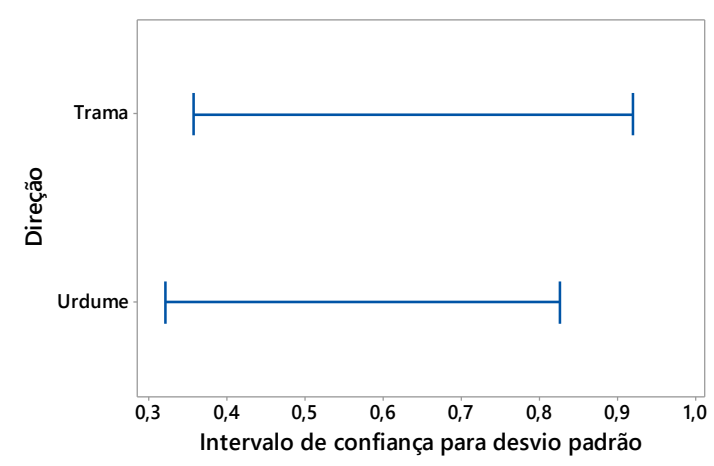

Fonte: Marcia Cristina Silva, 2018.

Na Figura 46, é possível verificar a sobreposição dos intervalos de confiança, confirmando a igualdade de variância dos resíduos.

A análise dos resíduos, juntamente com a ANOVA com valor de $\mathrm{p}$ ( $\mathrm{p}$-value) menor que 0,05 a hipótese nula é rejeitada em favor da hipótese alternativa de que as médias da variável resposta "velocidade de queima" relacionada com a variável explicativa "direção" no grupo de dados relativos ao "material poliéster (100\%PES), ligamento tela" são estatisticamente diferentes.

Para determinação do melhor tratamento, o qual para este estudo trata-se daquele que apresenta menor média para velocidade de queima, foi realizado o teste de múltiplas comparações com o melhor, proposto por Hsu. O resultado pode ser observado na Figura 43. 
Figura 43 - Teste de múltiplas comparações de HSU relacionando a variável resposta "velocidade de queima" com a variável explicativa "direção" no grupo de dados relativos ao "material poliéster (100\%PES) com ligamento tela":

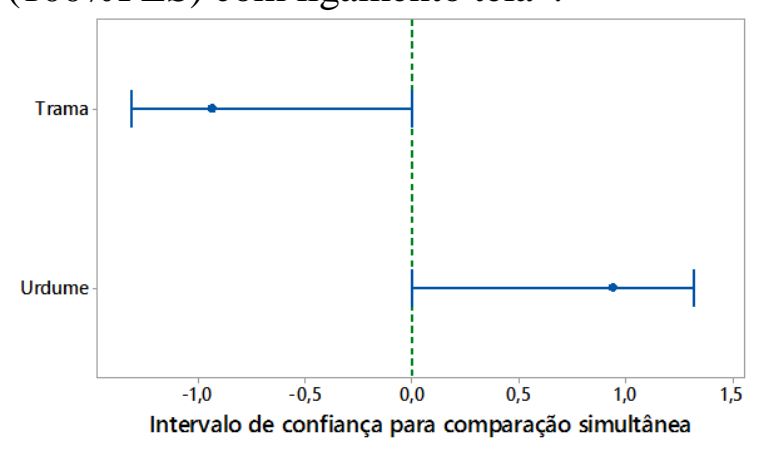

Fonte: Marcia Cristina Silva, 2018.

O intervalo de confiança criado pelo teste de Hsu, o qual demonstra a diferença entre cada média de velocidade de queima com a melhor das médias, apresentam intervalos com zero como ponto final, evidenciando que existe uma diferença estatisticamente significativa entre as médias correspondentes. $\mathrm{O}$ intervalo de confiança referente à trama possui grande parte dos valores negativos, portanto, pode-se dizer que ele é o melhor entre os demais.

\subsubsection{ANOVA - variável resposta "velocidade de queima" com relação a variável explicativa "direção" para grupo "material 67\%poliéster/33\% algodão $e$ ligamento sarja”.}

Os resultados obtidos na ANOVA estão descritos na Tabela 6.14.

Tabela 6. 14 - ANOVA - variável resposta "velocidade de queima" com relação a variável explicativa "direção" para o grupo "material $67 \%$ poliéster $33 \%$ algodão e ligamento sarja"

\begin{tabular}{cccccc}
\hline \multicolumn{5}{c}{ Análise de Variância } \\
\hline Fonte & Graus de & Soma dos & Quadrado & Estatística F & P-Value \\
& Liberdade & Quadrados & Médio & & \\
Direção & 1 & 0,02464 & 0,024643 & 2,65 & $\mathbf{0 , 1 2 1}$ \\
Erro & 18 & 0,16743 & 0,009301 & & \\
Total & 19 & 0,19207 & & & \\
\hline
\end{tabular}

Fonte: Marcia Cristina Silva, 2018

Para valor de p (p-value) maior que 0,05 a hipótese nula é aceita, indicando que que as médias para velocidade de queima do grupo a são estatisticamente iguais.

A Figura 44(a) e (b) demostra os valores de média para velocidade de queima e o intervalo de confiança. 
Figura 44 - Médias da variável resposta "velocidade de queima" para "67\%poliéster/33\% algodão e ligamento sarja" (a) Gráfico de efeitos; (b) Médias com respectivos de intervalos de confiança $(95 \%)$.

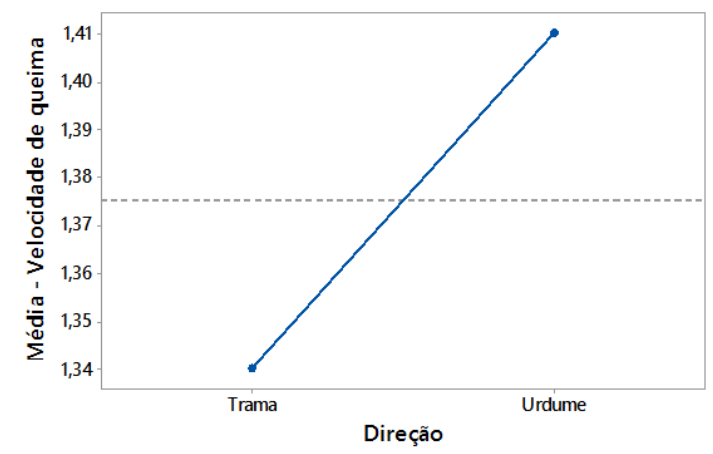

(a)

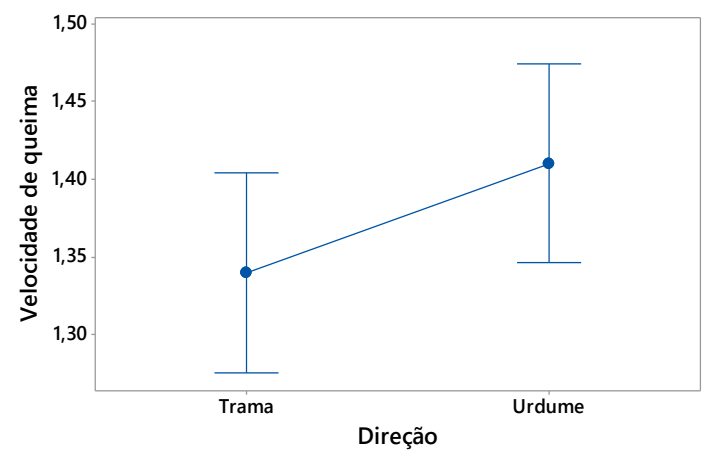

(b)

Fonte: Marcia Cristina Silva, 2018

Apesar da ANOVA demonstrar que as médias são estatisticamente iguais, na Figura 44(a), pode ser observado uma tendência, na qual velocidade de queima é ligeiramente maior na direção do urdume. Isto pode ser explicado pelo número maior de fios na direção do urdume conforme Tabela 6.3. A Figura 44(b) demonstra a sobreposição dos das faixas de médias com intervalos de confiança para trama e urdume, confirmando que as médias de velocidade de queima são estatisticamente iguais.

Para validação da análise foi realizada a verificação dos resíduos, conforme ilustrado na Figura 45(a) a (d). 
Figura 45 - Resultados da análise dos resíduos da ANOVA relacionando a variável resposta "velocidade de queima" com a variável explicativa "direção" no grupo de dados relativos ao "material 67\% poliéster/33\% algodão e ligamento sarja": (a) Histograma dos resíduos; (b) Papel de probabilidade; (c) Resíduos por valores ajustados; (d) Resíduos por Ordem de coleta.

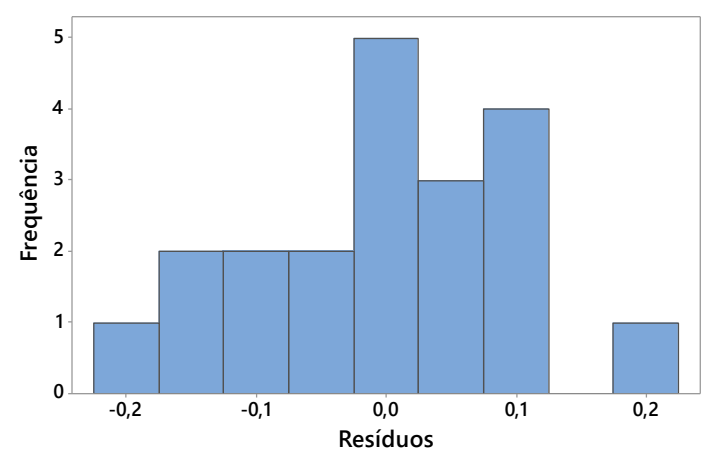

(a)

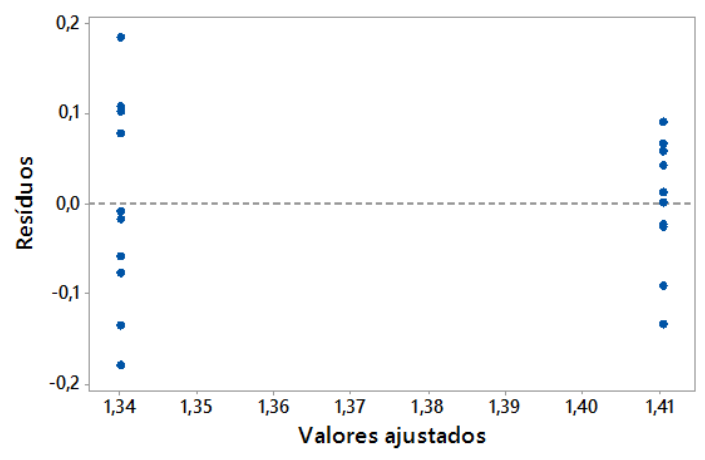

(c)

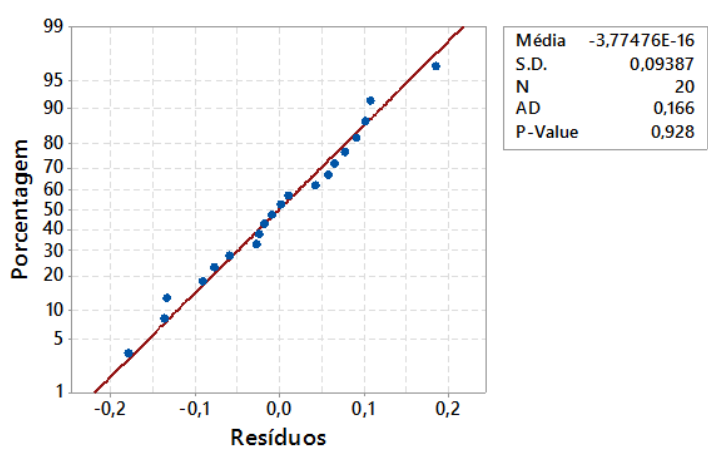

(b)

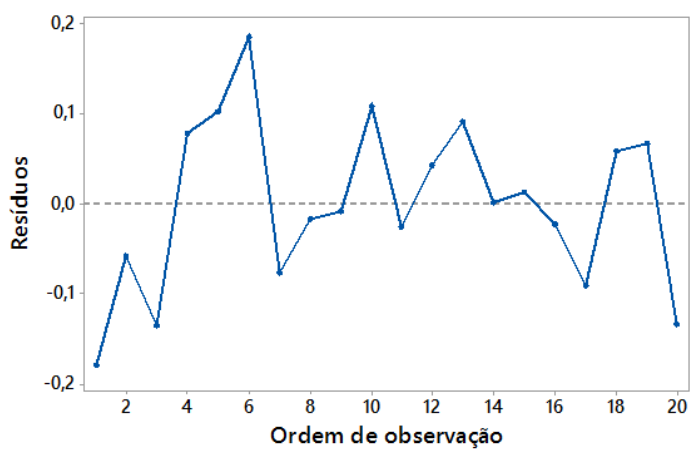

(d)

Fonte: Marcia Cristina Silva, 2018

O histograma (Figura 45(a)) e o papel de probabilidade (Figura 45(b)) demonstram a dispersão e distribuição dos resíduos e juntamente com teste de normalidade Anderson-Darling com valor de $\mathrm{p}$ ( $\mathrm{p}$-value) igual a 0,928. Para valor de $\mathrm{p}$ (p-value) maior que 0,05 a hipótese nula é aceita, indicando que os resíduos apresentam distribuição normal.

A Figura 45(c) demonstra graficamente que a variância dos resíduos apresenta igualdade. Também foi possível verificar a independência dos resíduos (Figura 45(d)), não apresentando comportamento sistemático, sem indício de influência externa ao experimento.

Para a confirmação de que os resíduos apresentam igualdade de variância foi realizado o teste de igualdade de variância Bartlet, resultando em valor de p ( $\mathrm{p}$-value) igual a 0,156 . 
Para valor de p (p-value) maior que 0,05 a hipótese nula é aceita, indicando que os resíduos apresentam igualdade de variância. Também foi possível ilustrar tal igualdade graficamente, conforme demonstrado na Figura 46.

Figura 46 - Teste de Levene para Análise de Variância dos resíduos relacionando a variável resposta "velocidade de queima" com a variável explicativa "direção" no grupo de dados relativos ao "material $67 \%$ poliéster/33\% algodão e ligamento sarja":

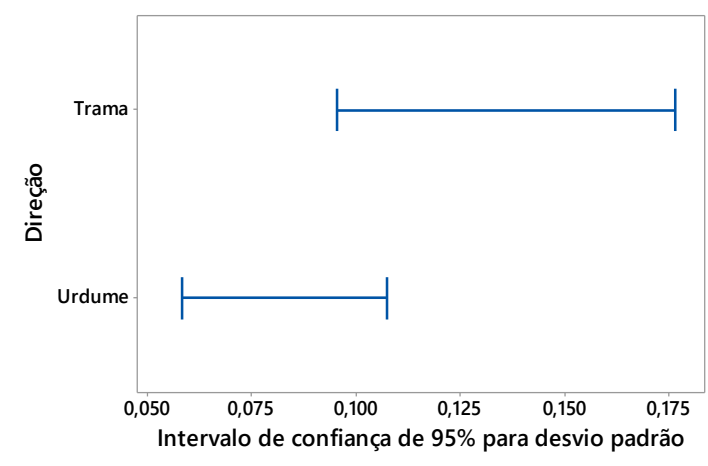

Fonte: Marcia Cristina Silva, 2018.

Na Figura 51, é possível verificar a sobreposição das médias dos resíduos com os respectivos intervalos de confiança, confirmando a igualdade de variância dos resíduos.

A análise dos resíduos, juntamente com a ANOVA com valor de $\mathrm{p}$ (p-value) maior que 0,05 a hipótese nula é aceita e confirma a hipótese de igualdade, confirma a hipótese de que as médias da variável resposta "velocidade de queima" relacionada com a variável explicativa "direção" no grupo de dados relativos ao "material 67\% poliéster/33\% algodão e ligamento sarja" são estatisticamente iguais.

\subsubsection{ANOVA - variável resposta "velocidade de queima" com relação a variável explicativa "direção" entre grupos de "material 67\%poliéster/33\% algodão e ligamento tela".}

Os resultados obtidos na ANOVA estão descritos na Tabela 6.15. 
Tabela 6. 15 - ANOVA - variável resposta "velocidade de queima" com relação a variável explicativa "direção" entre grupos de material " $67 \%$ poliéster $/ 33 \%$ algodão e ligamento tela"

\begin{tabular}{cccccc}
\hline \multicolumn{5}{c}{ Análise de Variância } \\
\hline Fonte & Graus de & Soma dos & Quadrado & Estatística F & P-Value \\
& Liberdade & Quadrados & Médio & & \\
Direção & 1 & 0,2222 & 0,2222 & 1,17 & $\mathbf{0 , 2 8 5}$ \\
Erro & 58 & 11,0516 & 0,1905 & & \\
Total & 59 & 11,2738 & & & \\
\hline
\end{tabular}

Fonte: Marcia Cristina Silva, 2018

$\mathrm{O}$ valor de $\mathrm{p}$ (p-value) maior que 0,05 demonstra que as médias para velocidade de queima são estatisticamente iguais. A Figura 47(a) e (b) demostra os valores de média para velocidade de queima e o intervalo de confiança.

Figura 47 - Médias da variável resposta "velocidade de queima" com relação a variável explicativa "direção" para o grupo de "material 67\%poliéster $33 \%$ algodão e ligamento tela" (a) Gráfico de efeitos; (b) Médias com respectivos de intervalos de confiança (95\%).

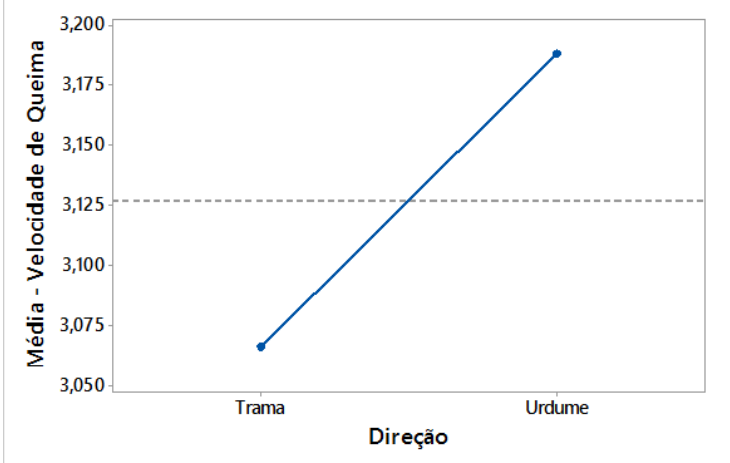

(a)

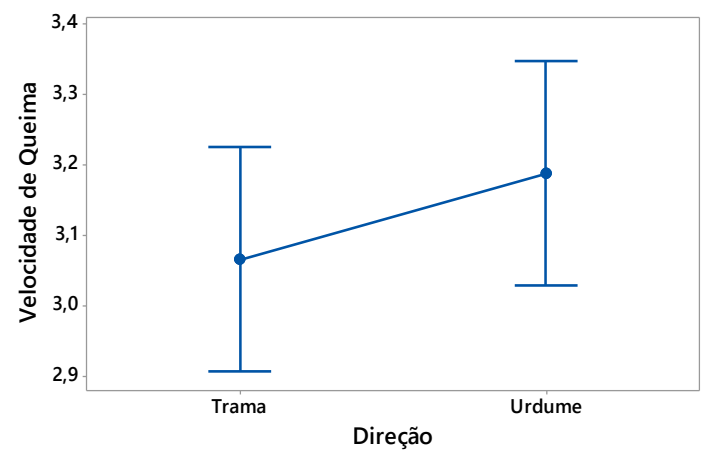

(b)

Fonte: Marcia Cristina Silva, 2018

Apesar da ANOVA demonstrar que as médias são estatisticamente iguais, na Figura 47(a), pode ser observado uma tendência, na qual velocidade de queima é ligeiramente maior na direção do urdume. Isto pode ser explicado pelo número maior de fios na direção do urdume conforme Tabela 6.3. A Figura 47(b) demonstra a sobreposição das faixas de médias com intervalos de confiança para trama e urdume, confirmando que as médias de velocidade de queima são estatisticamente iguais.

Para validação da análise foi realizada a verificação dos resíduos, conforme ilustrado na Figura 48(a) a (d). 
Figura 48 - Resultados da análise dos resíduos da ANOVA relacionando a variável resposta "velocidade de queima" com a variável explicativa "direção" no grupo de dados relativos ao "material 67\% poliéster/33\% algodão e ligamento tela" (a) Histograma dos resíduos; (b) Papel de probabilidade; (c) Resíduos por valores ajustados; (d) Resíduos por Ordem de coleta.

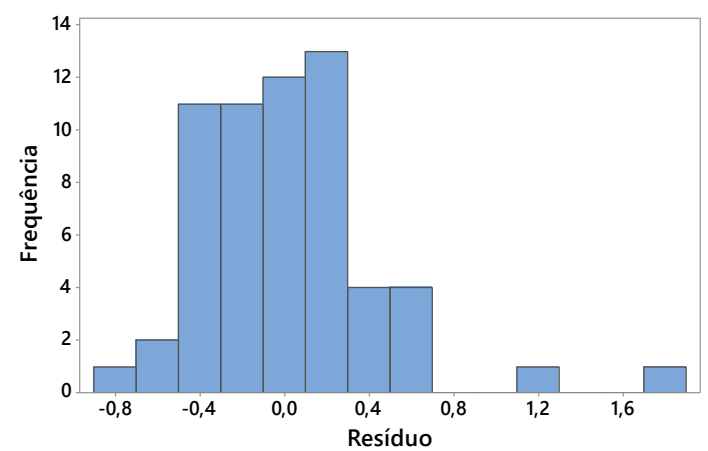

(a)

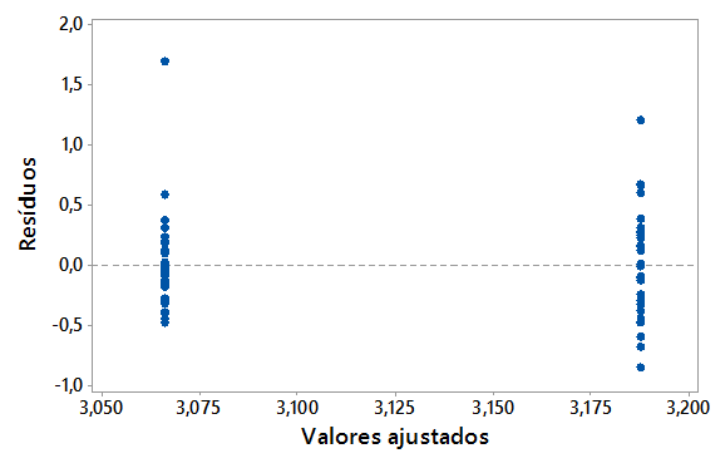

(c)

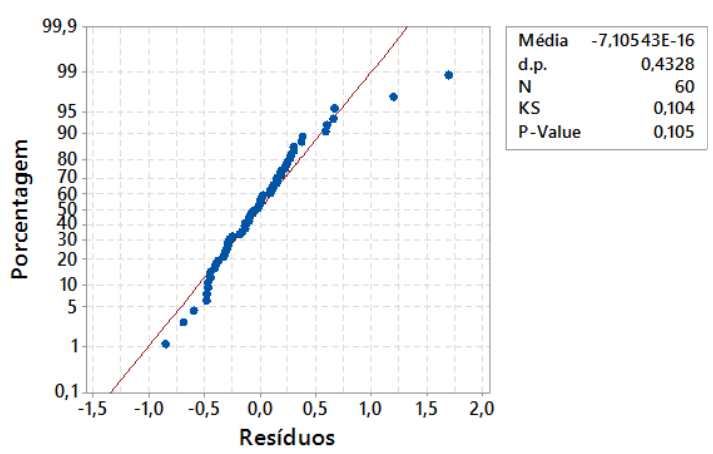

(b)

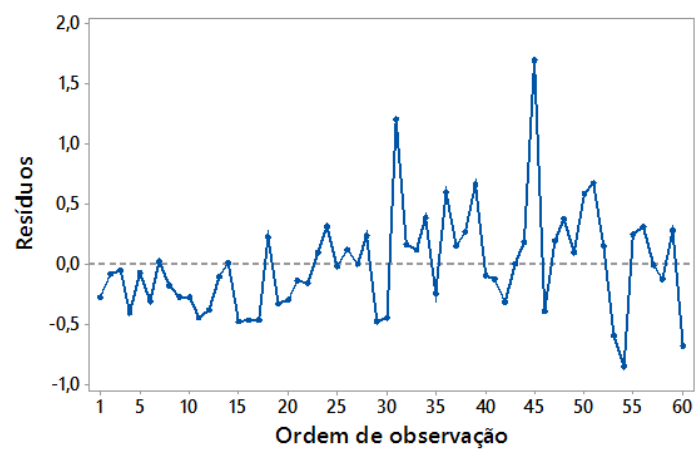

(d)

Fonte: Marcia Cristina Silva, 2018

O histograma (Figura 48(a)) e o papel de probabilidade (Figura 48(b)) demonstram a dispersão e distribuição dos resíduos e juntamente com teste de normalidade Kolmogorov-Smirnov com valor de $\mathrm{p}$ ( $\mathrm{p}$-value) igual a 0,105. Para valor de $\mathrm{p}$ (p-value) maior que 0,05 a hipótese nula é aceita, indicando que os resíduos apresentam distribuição normal.

A Figura 48(c) demonstra graficamente que a variância dos resíduos apresenta igualdade. Também foi possível verificar a independência dos resíduos (Figura 48(d)), não apresentando comportamento sistemático, sem indício de influência externa ao experimento.

Para a confirmação de que os resíduos apresentam igualdade de variância foi realizado o teste de igualdade de variância Bartlet, resultando em valor de p (p-value) igual a 0,156 . Para valor de $\mathrm{p}$ (p-value) maior que 0,05 a hipótese nula é aceita, indicando 
que os resíduos apresentam igualdade de variância. Também foi possível ilustrar tal igualdade graficamente, conforme demonstrado na Figura 49.

Figura 49 - Teste de Bartlett para Análise de Variância dos resíduos relacionando a variável resposta "velocidade de queima" com a variável explicativa "direção" no grupo de dados relativos ao "material $67 \%$ poliéster $33 \%$ algodão e ligamento tela":

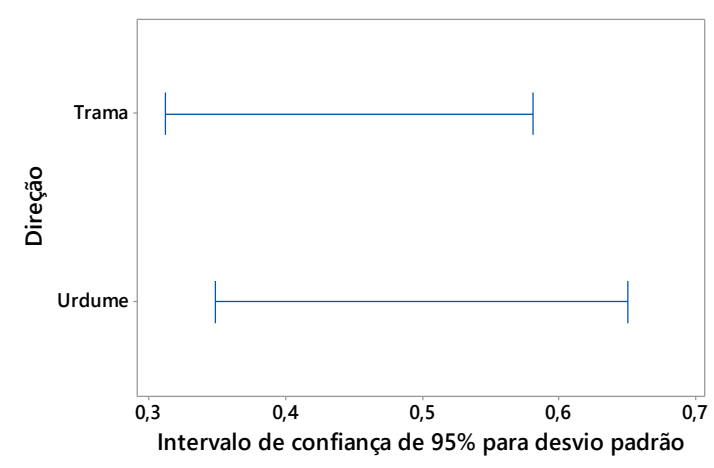

Fonte: Marcia Cristina Silva, 2018.

Na Figura 55, é possível verificar a sobreposição das médias dos resíduos com os respectivos intervalos de confiança, confirmando a igualdade de variância.

A análise dos resíduos, juntamente com a ANOVA com valor de $\mathrm{p}$ ( $\mathrm{p}$-value) maior que 0,05 a hipótese nula é aceita e confirma a hipótese de igualdade das médias da variável resposta "velocidade de queima" relacionada com a variável explicativa "direção" no grupo de dados relativos ao "material 67\% poliéster/33\% algodão e ligamento tela".

\subsubsection{ANOVA - variável resposta "velocidade de queima” com relação a variável explicativa "direção" entre grupos de "material 50\% lãa(WO)/ $50 \%$ poliéster(PES) e ligamento tela".}

Os resultados obtidos na ANOVA estão descritos na Tabela 6.16.

Tabela 6. 16 - ANOVA - variável resposta "velocidade de queima" com relação a variável explicativa "direção" entre grupos de "material $50 \%$ lã(WO)/ $50 \%$ poliéster(PES) e ligamento tela".

\begin{tabular}{cccccc}
\hline \multicolumn{5}{c}{ Análise de Variância } \\
\hline Fonte & Graus de & Soma dos & Quadrado & Estatística F & P-Value \\
& Liberdade & Quadrados & Médio & & \\
Direção & 1 & 0,000243 & 0,000243 & 0,02 & $\mathbf{0 , 8 8 8}$ \\
Erro & 18 & 0,213999 & 0,011889 & & \\
Total & 19 & 0,214241 & & & \\
\hline
\end{tabular}


Para valor de $\mathrm{p}$ (p-value) maior que 0,05 a hipótese nula é aceita, indicando que que as médias para velocidade de queima do grupo a são estatisticamente iguais.

A Figura 50(a) e (b) demostra os valores de média para velocidade de queima e o intervalo de confiança.

Figura 50 - Médias da variável resposta "velocidade de queima" com relação a variável explicativa "direção" para o grupo de "material 50\% lã(WO)/ 50\% poliéster(PES) e ligamento tela": (a) Gráfico de efeitos; (b) Médias com respectivos de intervalos de confiança $(95 \%)$.

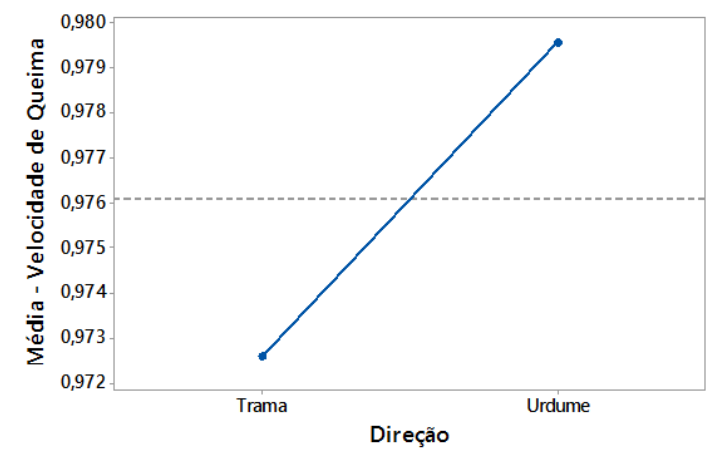

(a)

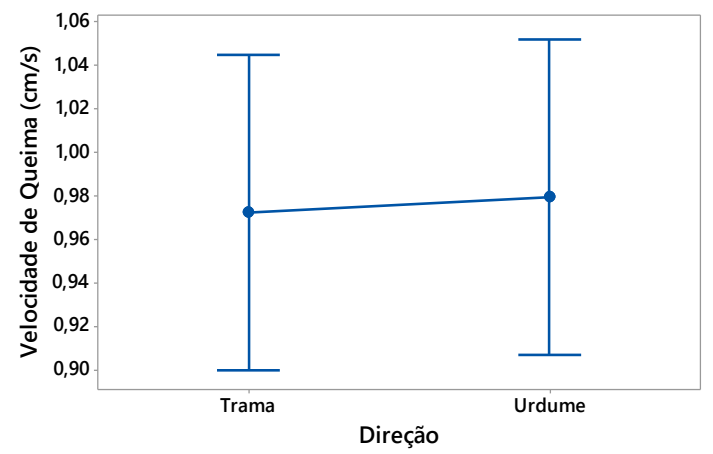

(b)

Fonte: Marcia Cristina Silva, 2018

Apesar da ANOVA demonstrar que as médias são estatisticamente iguais, na Figura 50(a), pode ser observado uma tendência, na qual velocidade de queima é ligeiramente maior na direção do urdume. A Figura 50(b) demonstra a sobreposição das faixas de médias com intervalos de confiança para trama e urdume, confirmando que as médias de velocidade de queima são estatisticamente iguais.

Para validação da análise foi realizada a verificação dos resíduos, conforme ilustrado na Figura 51(a) a (d). 
Figura 51 - Resultados da análise dos resíduos da ANOVA relacionando a variável resposta "velocidade de queima" com a variável explicativa "direção" no grupo de dados relativos ao "material 50\% lã(WO)/ 50\% poliéster(PES) e ligamento tela": (a) Histograma dos resíduos; (b) Papel de probabilidade; (c) Resíduos por valores ajustados; (d) Resíduos por Ordem de coleta.

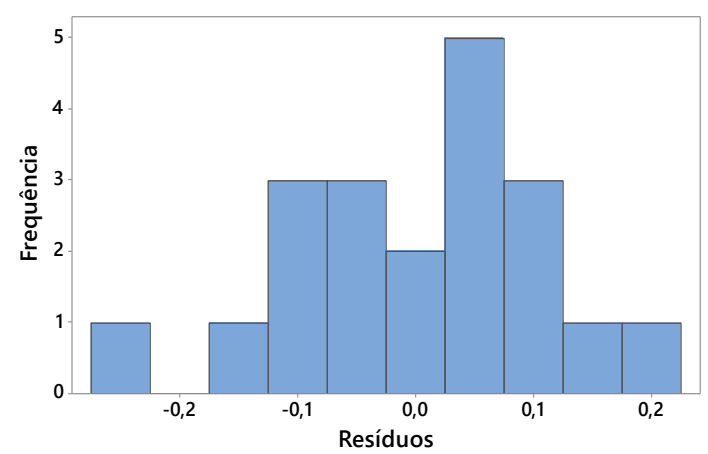

(a)

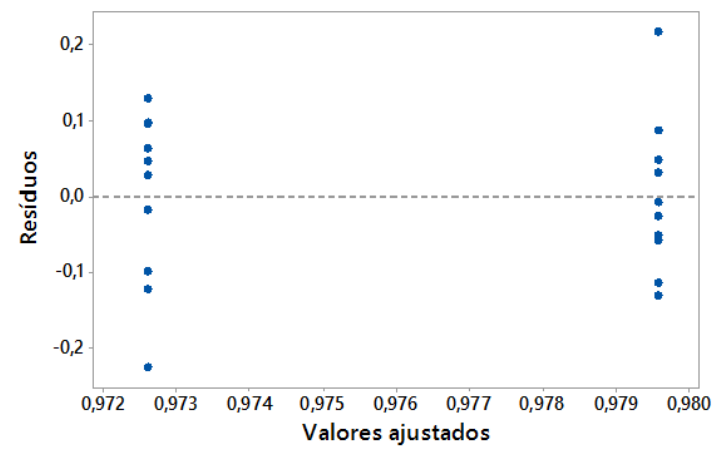

(c)

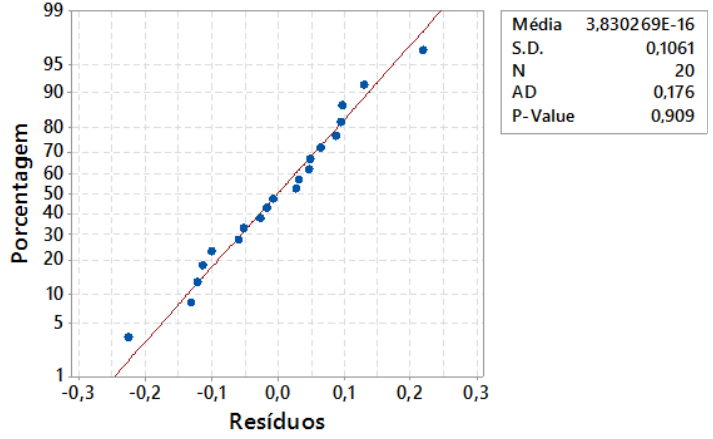

(b)

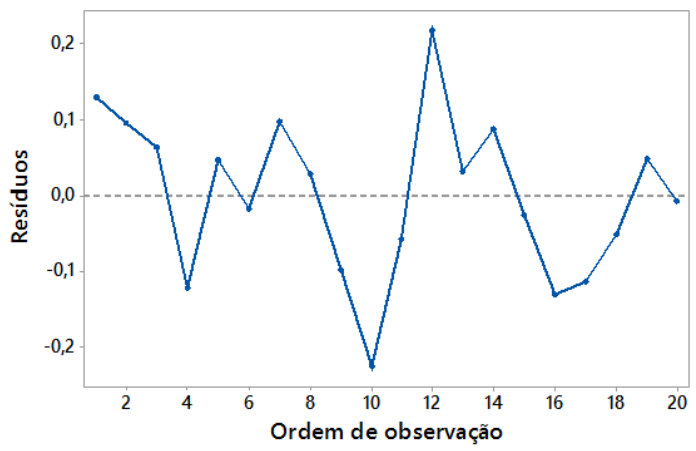

(d)

Fonte: Marcia Cristina Silva, 2018

O histograma (Figura 51(a)) e o papel de probabilidade (Figura 51(b)) demonstram a dispersão e distribuição dos resíduos e juntamente com teste de normalidade Anderson-Darling com valor de $\mathrm{p}$ ( $\mathrm{p}$-value) igual a 0,909. Para valor de $\mathrm{p}$ (p-value) maior que 0,05 a hipótese nula é aceita, indicando que os resíduos apresentam distribuição normal.

A Figura 51(c) demonstra graficamente que a variância dos resíduos apresenta igualdade. Também foi possível verificar a independência dos resíduos (Figura 51(d)), não apresentando comportamento sistemático, sem indício de influência externa ao experimento.

Para a confirmação de que os resíduos apresentam igualdade de foi realizado o teste de igualdade de variância Bartlet, resultando em valor $\mathrm{p}$ (p-value) igual a 0,757. Para valor de $\mathrm{p}$ (p-value) maior que 0,05 a hipótese nula é aceita, indicando que os resíduos 
apresentam igualdade de variância. Também foi possível ilustrar tal igualdade graficamente com o Teste de Levene, conforme demonstrado na Figura 52.

Figura 52 - Teste de Levene para Análise de Variância dos resíduos relacionando a variável resposta "velocidade de queima" com a variável explicativa "direção" no grupo de dados relativos ao "material 50\% lã(WO)/ 50\% poliéster(PES) e ligamento tela":

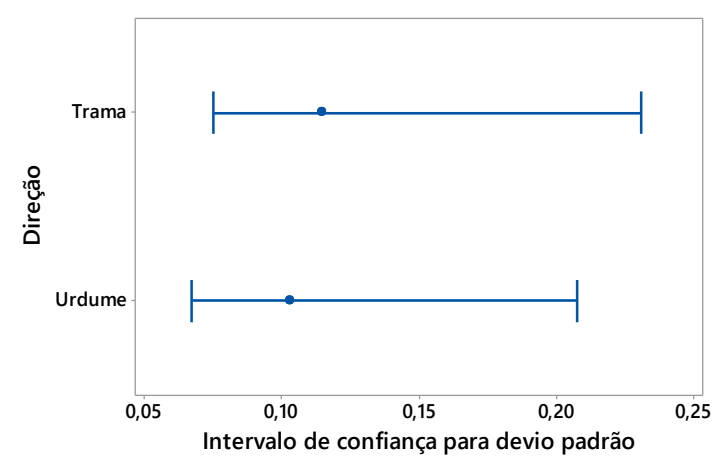

Fonte: Marcia Cristina Silva, 2018.

Na Figura 59, é possível verificar a sobreposição das médias dos resíduos com os respectivos intervalos de confiança, confirmando a igualdade de variância.

A análise dos resíduos, juntamente com a ANOVA com valor de $\mathrm{p}$ ( $\mathrm{p}$-value) maior que 0,05 a hipótese nula é aceita e confirma a hipótese de igualdade das médias da variável resposta "velocidade de queima" relacionada com a variável explicativa "direção" no grupo de dados relativos ao "material 50\% lã (WO) / 50\% poliéster (PES) e ligamento tela".

\subsubsection{Influência do material dos tecidos na velocidade de queima}

Os resultados foram agrupados por tipo de "ligamento" (tela e sarja) e "direção" (trama e urdume) e verificada a hipótese de igualdade de médias da variável resposta "velocidade de queima" com relação à variável explicativa "material” (100\% CO, 100\% PES e $67 \% \mathrm{PES} / 33 \% \mathrm{CO})$.

O nível de significância para tomada de decisão é $\alpha=0,05$ ou seja, para aceitar a hipótese nula é necessário um valor de $\mathrm{p}$ (p-value) maior que 0,05 . 


\subsubsection{ANOVA - variável resposta "velocidade de queima" com relação a variável explicativa "material" para o grupo "ligamento sarja, direção trama".}

Os resultados obtidos na ANOVA estão descritos na Tabela 6.17.

Tabela 6. 17 - ANOVA - variável resposta "velocidade de queima" com relação a variável explicativa "material" para o grupo "ligamento sarja, direção trama.

\begin{tabular}{cccccc}
\hline \multicolumn{5}{c}{ Análise de Variância } \\
\hline Fonte & Graus de & Soma dos & Quadrado & Estatística F & P-Value \\
& Liberdade & Quadrados & Médio & & \\
Material & 2 & 16,6807 & 8,34033 & 271,74 & $\mathbf{0 , 0 0 0}$ \\
Erro & 27 & 0,8287 & 0,03069 & & \\
Total & 29 & 17,5093 & & & \\
\hline
\end{tabular}

Fonte: Marcia Cristina Silva, 2018

O valor de $\mathrm{p}$ (p-value) menor que 0,05 a hipótese nula é rejeitada, indicando que pelo menos uma das médias é diferente. A Figura 53(a) e (b) demonstra os valores de média para velocidade de queima e o intervalo de confiança para velocidade de queima do grupo ligamento sarja, direção trama.

Figura 53 - Médias da variável resposta "velocidade de queima" com relação a variável explicativa "material" para o grupo para "ligamento sarja, direção trama": (a) Gráfico de efeitos; (b) Médias com respectivos de intervalos de confiança (95\%).

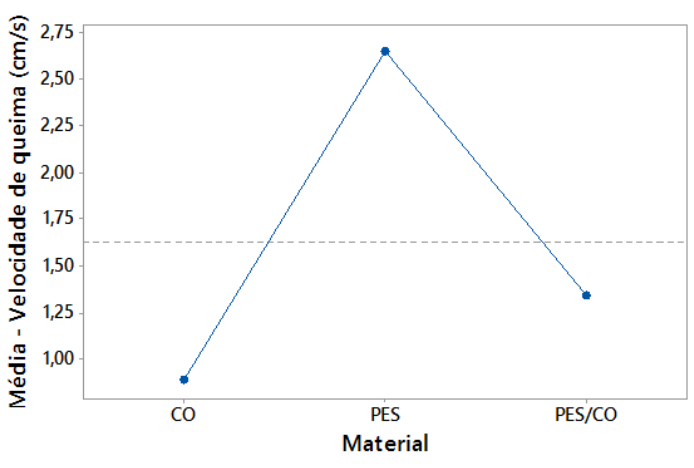

(a)

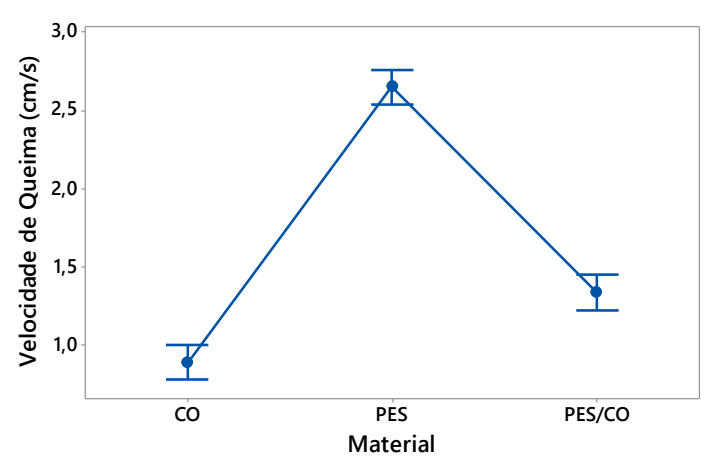

(b)

Fonte: Marcia Cristina Silva, 2018

A ANOVA demonstra que as médias são estatisticamente diferentes e na Figura 53 (a), pode ser observado que a velocidade de queima é maior para o material $100 \%$ PES. A Figura 53(b) não apresenta sobreposição das faixas de médias com intervalos de confiança para trama e urdume, confirmando que as médias de velocidade de queima não são estatisticamente iguais.

Para validação da análise foi realizada a verificação dos resíduos, conforme ilustrado na Figura 54(a) a (d). 
Figura 54 - Resultados da análise dos resíduos da ANOVA relacionando a variável resposta "velocidade de queima" com a variável explicativa "material" no grupo de dados relativos ao "ligamento sarja, direção trama":(a) Histograma dos resíduos; (b) Papel de probabilidade; (c) Resíduos por valores ajustados; (d) Resíduos por Ordem de coleta.

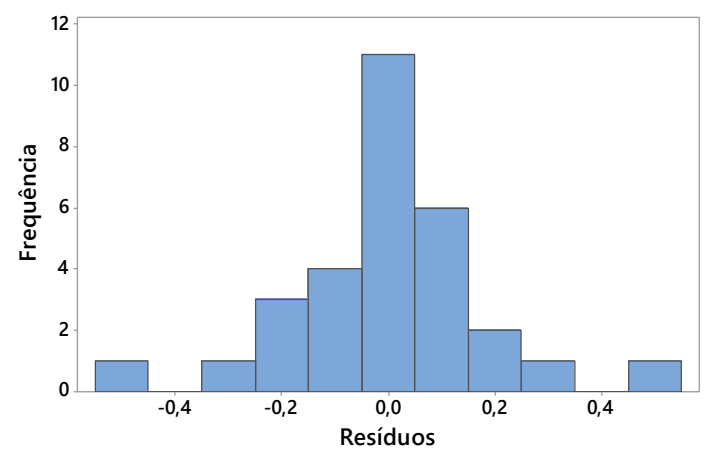

(a)

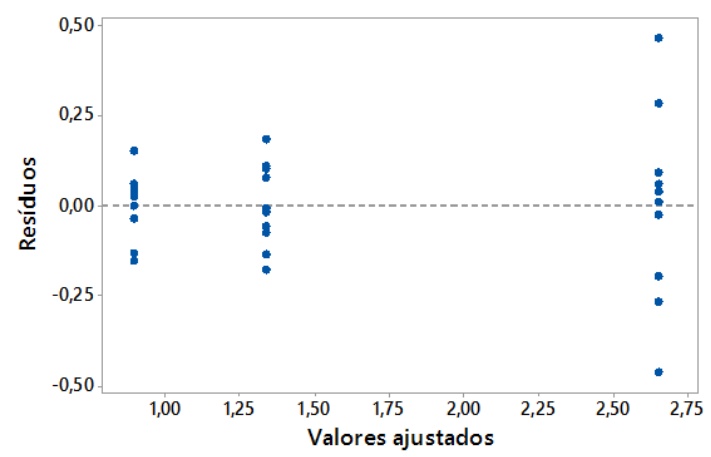

(c)

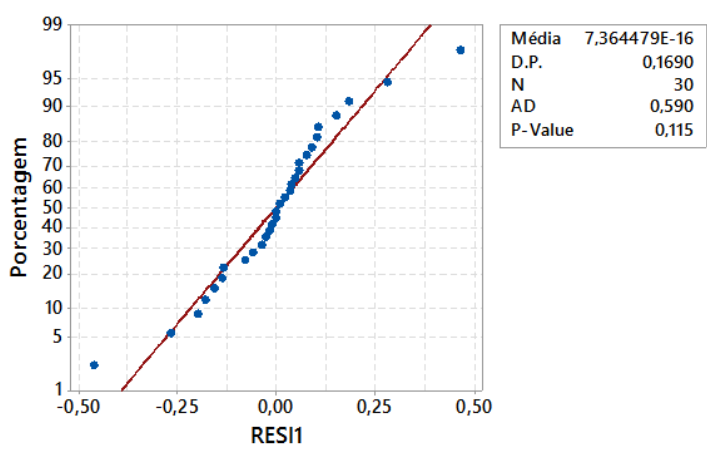

(b)

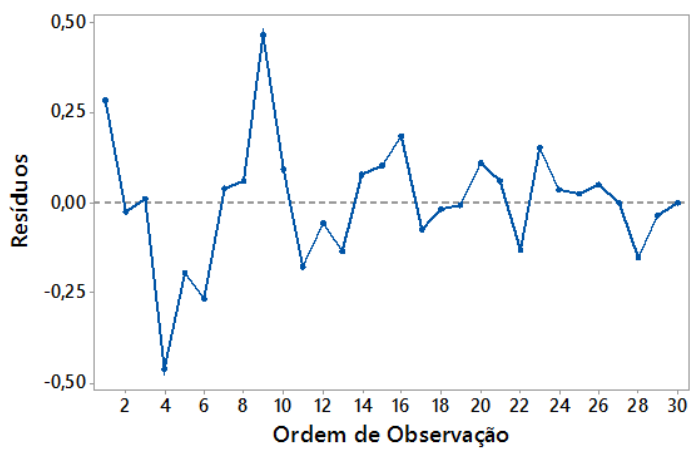

(d)

Fonte: Marcia Cristina Silva, 2018

O histograma (Figura 54(a)) e o papel de probabilidade (Figura 54 (b)) demonstram a dispersão e distribuição dos resíduos e juntamente com teste de normalidade Anderson-Darling com valor de $\mathrm{p}$ (p-value) igual a 0,115. confirmam que os resíduos apresentam distribuição normal. Para valor de $\mathrm{p}$ ( $\mathrm{p}$-value) maior que $0,05 \mathrm{a}$ hipótese nula é aceita, indicando que os resíduos apresentam distribuição normal.

A Figura 54(c) demonstra graficamente que a variância dos resíduos apresenta igualdade. Também foi possível verificar a independência dos resíduos (Figura 54(d)), não apresentando comportamento sistemático, sem indício de influência externa ao experimento.

Para a confirmação de que os resíduos apresentam igualdade de variância foram realizados o teste de igualdade de variâncias de Bartlet, valor p (p-value) igual a 0,004; e o teste de Levene, com p-value de 0,059. Para valor de p (p-value) maior que 0,05 a hipótese nula é aceita, indicando que os resíduos apresentam igualdade de variância. 
Também foi possível ilustrar tal igualdade graficamente, conforme demonstrado na

\section{Figura 55.}

Figura 55 - Teste de Levene para Análise de Variância dos resíduos relacionando a variável resposta "velocidade de queima" com a variável explicativa "material" no grupo de dados relativos ao "ligamento sarja, direção trama"

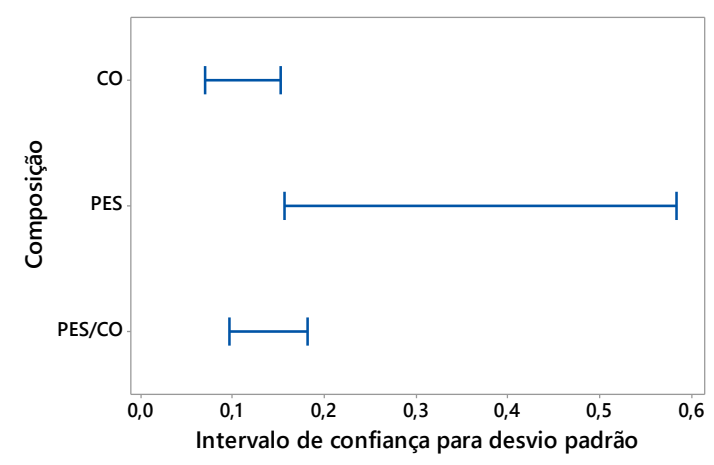

Fonte: Marcia Cristina Silva, 2018.

Na Figura 55, é possível verificar a sobreposição das médias dos resíduos com os respectivos intervalos de confiança, confirmando a igualdade de variância.

A análise dos resíduos, juntamente com a ANOVA com valor de p (p-value) menor que 0,05 a hipótese nula é rejeitada em favor da hipótese alternativa de que para as médias da variável resposta "velocidade de queima" relacionada com a variável explicativa "material" no grupo de dados relativos à "ligamento sarja, direção trama", pelo menos uma média é diferente.

Para determinação do melhor tratamento, o qual para este estudo trata-se daquele que apresenta menor média para velocidade de queima, foi realizado o teste de múltiplas comparações com o melhor, proposto por Hsu. O resultado pode ser observado na Figura 56. 
Figura 56 - Teste de múltiplas comparações de HSU relacionando a variável resposta "velocidade de queima" com a variável explicativa "material" no grupo de dados relativos ao "ligamento sarja, direção trama".

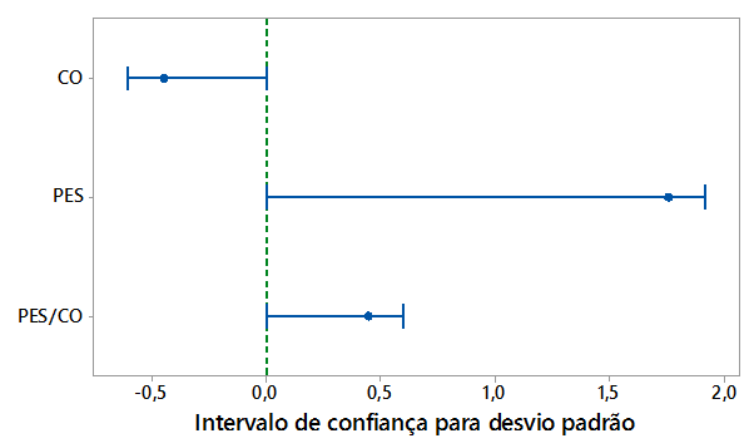

Fonte: Marcia Cristina Silva, 2018.

O intervalo de confiança criado pelo teste de Hsu, o qual demonstra a diferença entre cada média de velocidade de queima com a melhor das médias, apresentam intervalos com zero como ponto final, evidenciando que existe uma diferença estatisticamente significativa entre as médias correspondentes. O intervalo de confiança referente ao material $100 \% \mathrm{CO}$ possui grande parte dos valores negativos, portanto, podese dizer que ele é o melhor entre os demais.

\subsubsection{ANOVA - variável resposta "velocidade de queima" com relação a variável explicativa "material" entre grupos de "ligamento sarja, direção urdume".}

Os resultados obtidos na ANOVA estão descritos na Tabela 6.18.

Tabela 6. 18 - ANOVA - variável resposta "velocidade de queima" com relação a variável explicativa "material" entre grupos de "ligamento sarja, direção urdume".

\begin{tabular}{c|ccccc}
\hline \multicolumn{5}{c}{ Análise de Variância } \\
\hline Fonte & Graus de & Soma dos & Quadrado & Estatística F & P-Value \\
& Liberdade & Quadrados & Médio & & \\
Material & 2 & 2,8391 & 1,41957 & 44,04 & $\mathbf{0 , 0 0 0}$ \\
Erro & 27 & 0,8703 & 0,03224 & & \\
Total & 29 & 3,7095 & & & \\
\hline
\end{tabular}

Fonte: Marcia Cristina Silva, 2018

$\mathrm{O}$ valor de $\mathrm{p}$ (p-value) menor que 0,05 demonstra que as médias para velocidade de queima são estatisticamente diferentes.

A Figura 57(a) e (b) demonstra os valores de média para velocidade de queima e o intervalo de confiança para velocidade de queima do grupo ligamento sarja, direção trama. 
Figura 57 - Médias da variável resposta "velocidade de queima" para "ligamento sarja, direção urdume": (a) Gráfico de efeitos; (b) Médias com respectivos de intervalos de confiança $(95 \%)$.

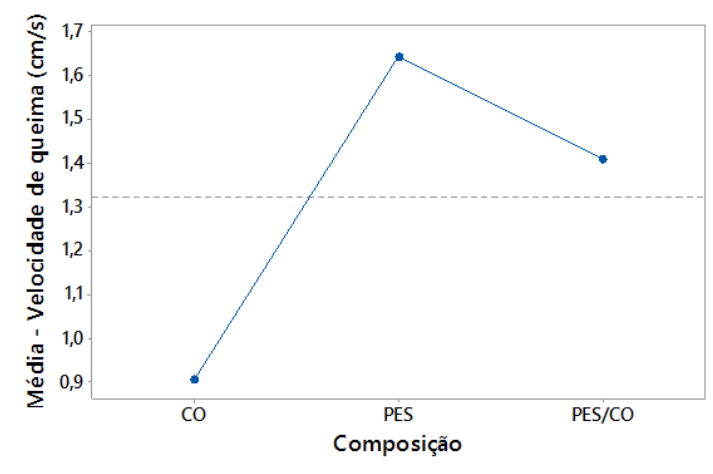

(a)

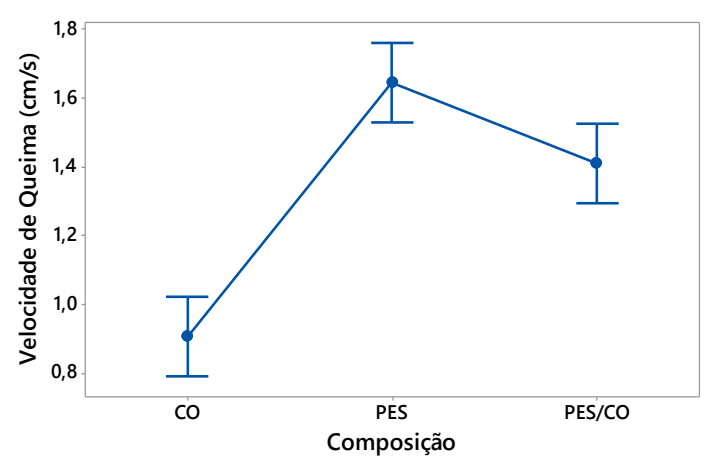

(b)

Fonte: Marcia Cristina Silva, 2018

A ANOVA demonstra que as médias são estatisticamente diferentes e na Figura 57(a), pode ser observado que a velocidade de queima é maior para o material 100\% PES. A Figura 57(b) não apresenta sobreposição de todas as faixas de médias com intervalos de confiança para trama e urdume, confirmando que pelo menos uma das médias de velocidade de queima é diferente.

Para validação da análise foi realizada a verificação dos resíduos, conforme ilustrado na Figura 58(a) a (d). 
Figura 58 - Resultados da análise dos resíduos da ANOVA relacionando a variável resposta "velocidade de queima" com a variável explicativa "material" no grupo de dados relativos ao "ligamento sarja, direção urdume":(a) Histograma dos resíduos; (b) Papel de probabilidade; (c) Resíduos por valores ajustados; (d) Resíduos por Ordem de coleta.

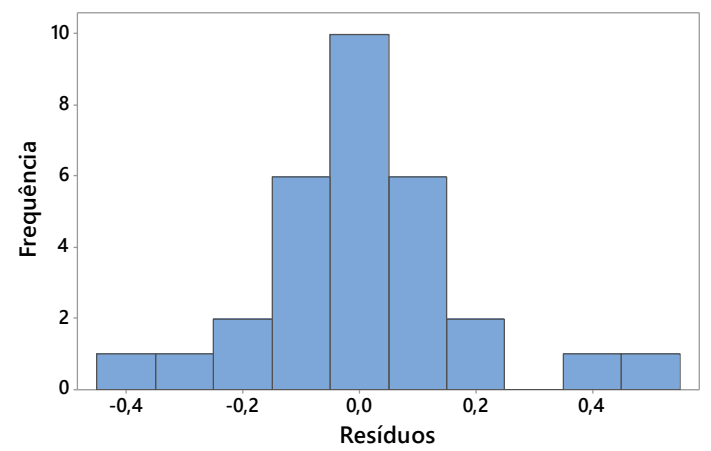

(a)

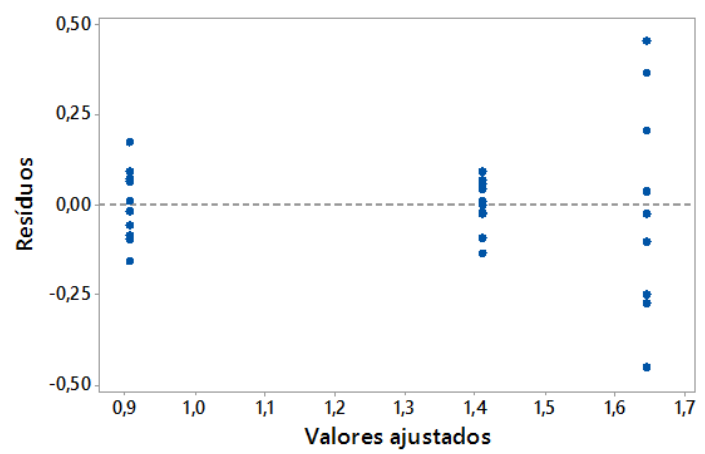

(c)

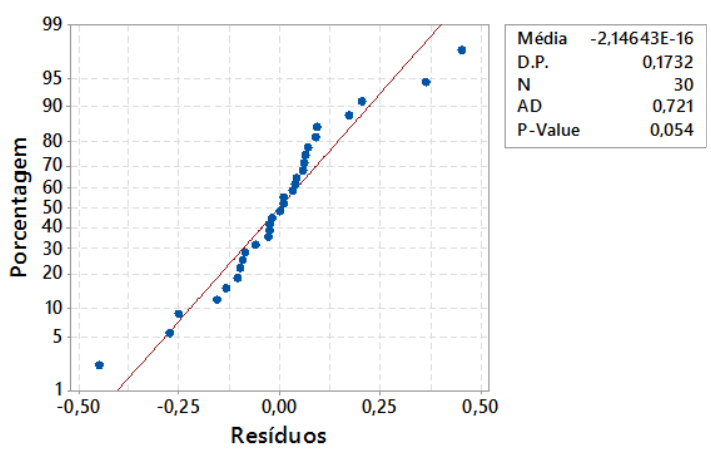

(b)

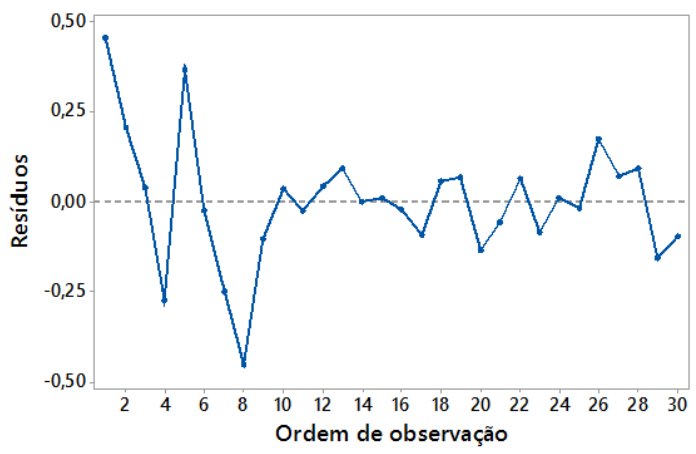

(d)

Fonte: Marcia Cristina Silva, 2018

O histograma (Figura 58(a)) e o papel de probabilidade (Figura 58(b)) demonstram a dispersão e distribuição dos resíduos e juntamente com teste de normalidade Anderson-Darling com valor de $\mathrm{p}$ ( $\mathrm{p}$-value) igual a 0,054. Para valor de $\mathrm{p}$ (p-value) maior que 0,05 a hipótese nula é aceita, indicando que os resíduos apresentam distribuição normal.

A Figura 58(c), demonstra graficamente que a variância dos resíduos não apresenta igualdade, testes de Bartlet, $\mathrm{p}$ (p-value) igual a 1,41E-04. Para valor de $\mathrm{p}$ (pvalue) menor que 0,05 a hipótese nula é rejeitada, indicando que os resíduos não apresentam igualdade de variância.

Não sendo possível validar a ANOVA, uma vez que os resíduos não apresentam igualdade de variância, o teste não paramétrico de Kruskal- Wallis (Tabela 6.19) foi conduzido para verificação da igualdade das médias da variável resposta "velocidade de 
queima" relacionada com a variável explicativa "material" no grupo de dados relativos ao "ligamento sarja, direção urdume"

Tabela 6. 19 - Teste Kruskal-Wallis para a variável resposta "velocidade de queima" com a variável explicativa "material" no grupo de dados relativos ao "ligamento sarja, direção urdume".

\begin{tabular}{lr}
\multicolumn{1}{c}{ Informação } & \multicolumn{1}{c}{ Valor } \\
Kruskal-Wallis qui-quadrado & 21,10 \\
Graus de Liberdade & 2 \\
P-valor & $2,62 \mathrm{E}-05$ \\
\hline
\end{tabular}

Marcia Cristina Silva, 2018

Com valor de $\mathrm{p}$ (p-value) igual a 2,62E-05 (Tabela 6.19) a hipótese nula de igualdade foi rejeitada em um nível de significância $\alpha=0,05$ em favor da hipótese alternativa considerando-se que pelo menos uma diferença entre o grupo de materiais.

Para determinação do melhor tratamento, o qual para este estudo trata-se daquele que apresenta menor média para velocidade de queima, foi realizado o teste de múltiplas comparações com o melhor, proposto por Hsu. O resultado pode ser observado na Figura 59.

Figura 59 - Teste de múltiplas comparações de HSU variável resposta "velocidade de queima" com a variável explicativa "material" no grupo de dados relativos ao "ligamento sarja, direção urdume

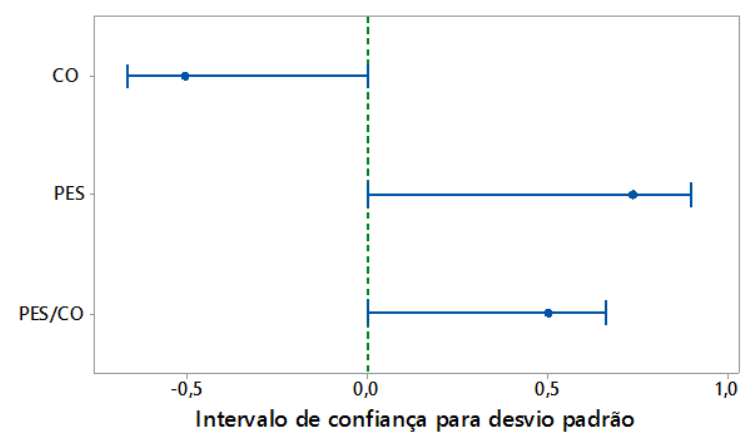

Fonte: Marcia Cristina Silva, 2018

O intervalo de confiança criado pelo teste de Hsu, o qual demonstra a diferença entre cada média de velocidade de queima com a melhor das médias, apresentam intervalos com zero como ponto final, evidenciando que existe uma diferença estatisticamente significativa entre as médias correspondentes. O intervalo de confiança referente a $100 \% \mathrm{CO}$ possui grande parte dos valores negativos, portanto, pode-se dizer que ele é o melhor entre os demais. 


\subsubsection{ANOVA - variável resposta "velocidade de queima" com relação a variável explicativa "material" entre grupos de "ligamento tela, direção trama".}

Os resultados obtidos na ANOVA estão descritos na Tabela 6.20.

Tabela 6. 20 - ANOVA - variável resposta "velocidade de queima" com relação a variável explicativa "material" entre grupos de "ligamento tela, direção trama".

\begin{tabular}{c|ccccc}
\hline \multicolumn{5}{c}{ Análise de Variância } \\
\hline Fonte & Graus de & Soma dos & Quadrado & Estatística F & P-Value \\
& Liberdade & Quadrados & Médio & & \\
Material & 1 & 0,2529 & 0,2529 & 1,26 & $\mathbf{0 , 2 7 0}$ \\
Erro & 36 & 7,2447 & 0,2012 & & \\
Total & 37 & 7,4976 & & & \\
\hline
\end{tabular}

Fonte: Marcia Cristina Silva, 2018

Para valor de p (p-value) maior que 0,05 a hipótese nula é aceita, indicando que que as médias para velocidade de queima do grupo são estatisticamente iguais.

A Figura 60(a) e (b) demostra os valores de média para velocidade de queima e o intervalo de confiança para "velocidade de queima" relacionado ao "material" do grupo "ligamento tela, direção trama".

Figura 60 - Médias da variável resposta "velocidade de queima" por "material" para grupo "ligamento tela, direção trama": (a) Gráfico de efeitos; (b) Médias com respectivos de intervalos de confiança (95\%).

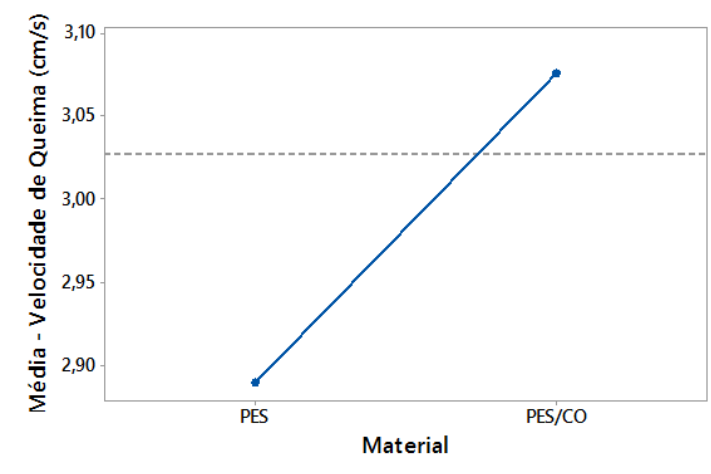

(a)

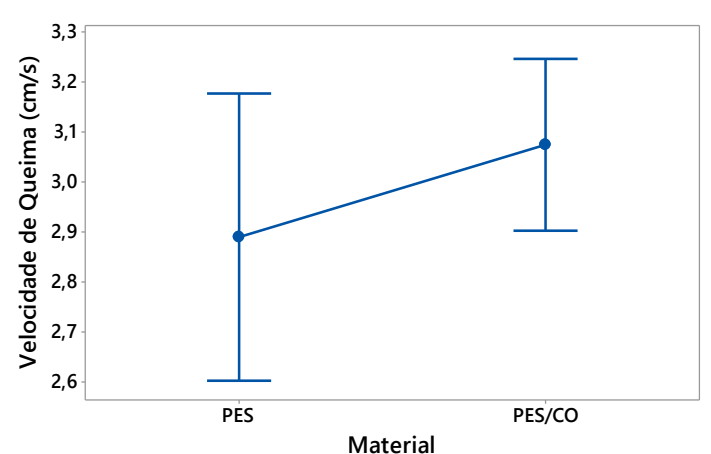

(b)

Fonte: Marcia Cristina Silva, 2018

Apesar da ANOVA demonstrar que as médias são estatisticamente iguais, na Figura 60(a), pode ser observado uma tendência, na qual velocidade de queima é ligeiramente maior para o material $67 \% \mathrm{PES} / 33 \% \mathrm{CO}$. Isto pode ser pela porcentagem de cada fibra no tecido misto. A Figura 60(b) demonstra a sobreposição das faixas de médias com intervalos de confiança para trama e urdume, confirmando que as médias de velocidade de queima são estatisticamente iguais. 
Para validação da análise foi realizada a verificação dos resíduos, conforme ilustrado na Figura 61(a) a (d).

Figura 61 - Resultados da análise dos resíduos da ANOVA relacionando a variável resposta "velocidade de queima" com a variável explicativa "material" no grupo de dados relativos ao "ligamento tela, direção trama":(a) Histograma dos resíduos; (b) Papel de probabilidade; (c) Resíduos por valores ajustados; (d) Resíduos por Ordem de coleta.

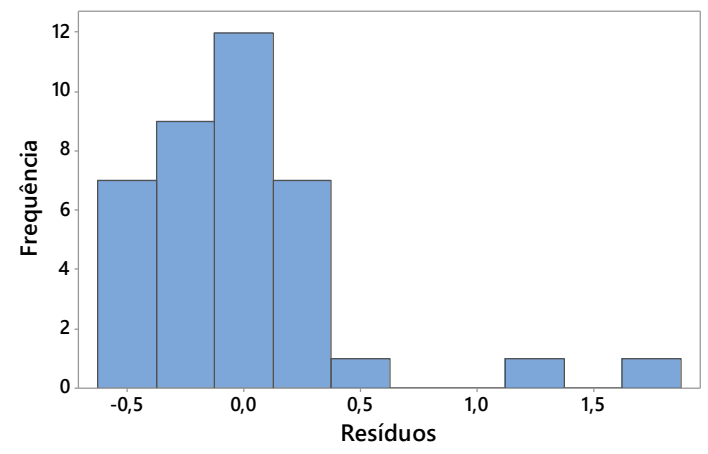

(a)

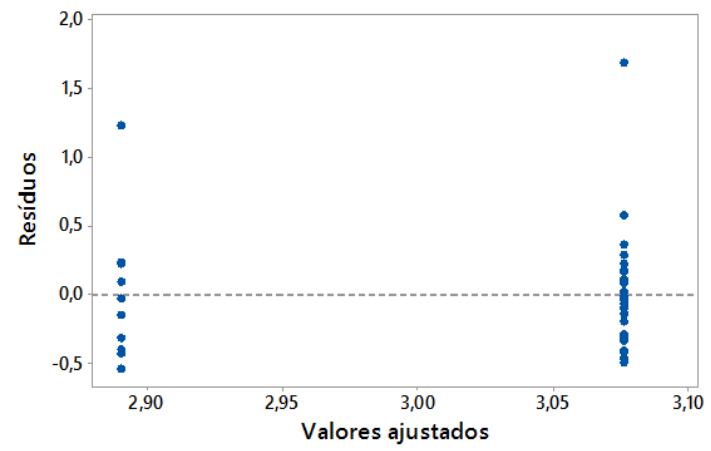

(c)

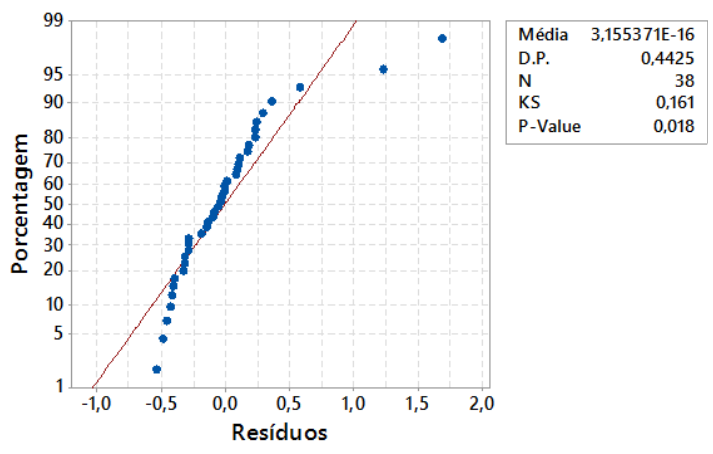

(b)

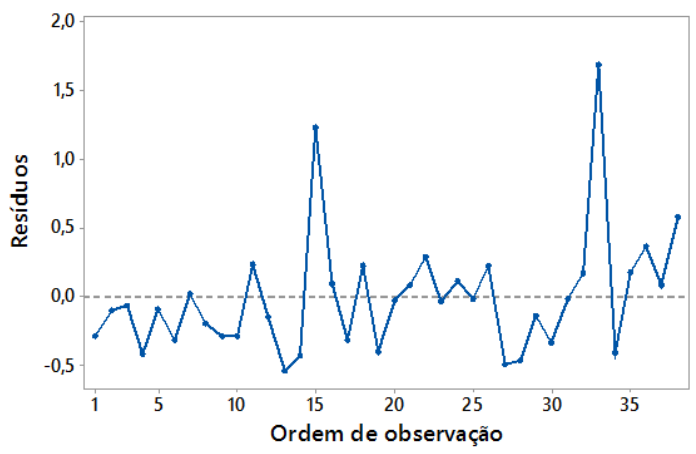

(d)

Fonte: Marcia Cristina Silva, 2018

O histograma dos resíduos (Figura 61(a)) demonstra a sua dispersão e distribuição e juntamente com o papel da probabilidade (Figura 61(b)) e teste de normalidade Kolmogorov-Smirnov com valor de p (p-value) igual a 0,018 confirmam que os dados não apresentam distribuição normal.

A Figura 61 (c), demonstra graficamente que a variância dos resíduos apresenta igualdade. Também foi possível verificar a independência dos resíduos, pois a Figura 61(d), não apresenta comportamento sistemático, sem indício de influencia externa ao experimento.

Para a confirmação de que os resíduos apresentam igualdade de variância foi realizado o teste de igualdade de variância de Levene resultando em valore de $\mathrm{p}$ ( $\mathrm{p}$-value) igual a 0,486. Para valor de $\mathrm{p}$ (p-value) maior que 0,05 a hipótese nula é aceita, indicando que os resíduos apresentam igualdade de variância. 
Não sendo possível validar a ANOVA, uma vez que os resíduos não apresentam distribuição normal, o teste não paramétrico de Kruskal- Wallis (Tabela 6.21) foi conduzido para verificação da igualdade da variável resposta "velocidade de queima" relacionada com a variável explicativa "material" no grupo de dados relativos ao "ligamento tela, direção trama"

Tabela 6. 21 - Teste Kruskal-Wallis para a variável resposta "velocidade de queima" com a variável explicativa "material" no grupo de dados relativos ao "ligamento tela, direção trama".

\begin{tabular}{lr}
\hline \multicolumn{1}{c}{ Informação } & Valor \\
Kruskal-Wallis qui-quadrado & 2,8594 \\
Graus de Liberdade & 1 \\
P-valor & 0,091 \\
\hline
\end{tabular}

Marcia Cristina Silva, 2018

Com valor de p (p-value) igual a 0,091 (Tabela 6.21) a hipótese nula de igualdade foi aceita em um nível de significância $\alpha=0,05$ considerando-se que as médias para a variável resposta "velocidade de queima" com a variável explicativa "material" no grupo de dados relativos ao "ligamento tela, direção trama" são estatisticamente iguais.

\subsubsection{ANOVA - variável resposta "velocidade de queima" com relação a variável explicativa "material" entre grupos de "ligamento tela, direção urdume.}

Os resultados obtidos na ANOVA estão descritos na Tabela 6.22.

Tabela 6. 22 - ANOVA - variável resposta "velocidade de queima" com relação a variável explicativa "material" entre grupos de "ligamento tela, direção urdume".

\section{Análise de Variância}

\begin{tabular}{|c|c|c|c|c|c|}
\hline Fonte & $\begin{array}{l}\text { Graus de } \\
\text { Liberdade }\end{array}$ & $\begin{array}{l}\text { Soma dos } \\
\text { Quadrados }\end{array}$ & $\begin{array}{l}\text { Quadrado } \\
\text { Médio }\end{array}$ & Estatística F & P-Value \\
\hline Material & 1 & 3,065 & 3,0655 & 14,44 & 0,001 \\
\hline Erro & 38 & 8,065 & 0,2122 & & \\
\hline Total & 39 & 11,131 & & & \\
\hline
\end{tabular}

Fonte: Marcia Cristina Silva, 2018

$\mathrm{O}$ valor de $\mathrm{p}$ ( $\mathrm{p}$-value) menor que 0,05 demonstra que as médias para velocidade de queima são estatisticamente diferentes. 
A Figura 62(a) e (b) demonstra os valores de média para velocidade de queima e o intervalo de confiança para velocidade de queima do grupo ligamento tela, direção urdume.

Figura 62 - Médias da variável resposta "velocidade de queima" para "ligamento tela, direção urdume": (a) Gráfico de efeitos; (b) Médias com respectivos de intervalos de confiança (95\%).

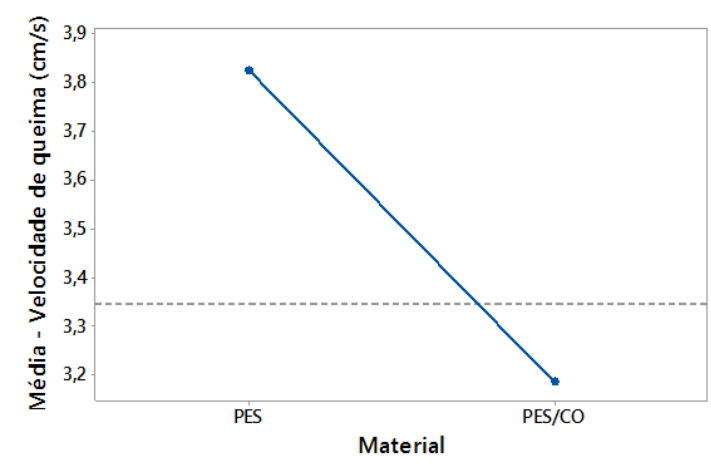

(a)

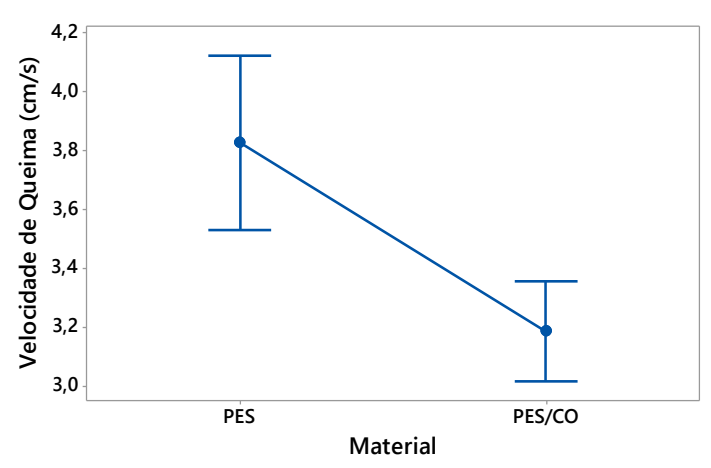

(b)

Fonte: Marcia Cristina Silva, 2018

A ANOVA demonstrar que as médias são estatisticamente diferentes e na Figura 62(a), pode ser observado que a velocidade de queima é maior para o material 100\% PES. A Figura 62(b) não apresenta sobreposição das faixas de médias com intervalos de confiança para $100 \%$ PES e $67 \% \mathrm{PES} / 33 \% \mathrm{CO}$, confirmando que as médias de velocidade de queima não são estatisticamente iguais.

Para validação da análise foi realizada a verificação dos resíduos, conforme ilustrado na Figura 63(a) a (d). 
Figura 63 - Resultados da análise dos resíduos da ANOVA relacionando a variável resposta "velocidade de queima" com a variável explicativa "material" no grupo de dados relativos ao "ligamento tela, direção urdume":(a) Histograma dos resíduos; (b) Papel de probabilidade; (c) Resíduos por valores ajustados; (d) Resíduos por Ordem de coleta.

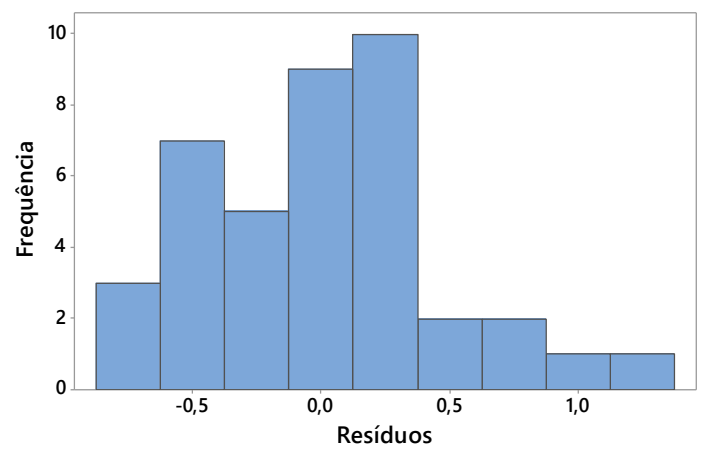

(a)

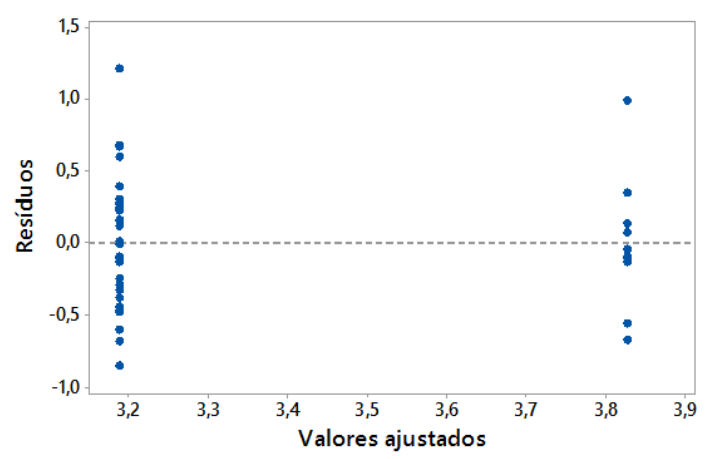

(c)

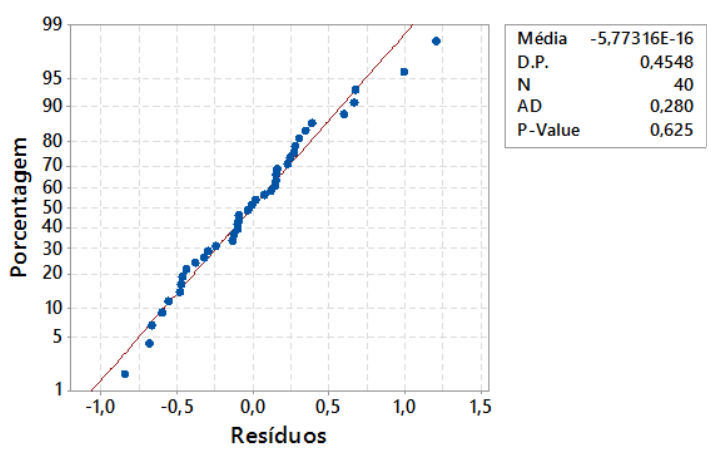

(b)

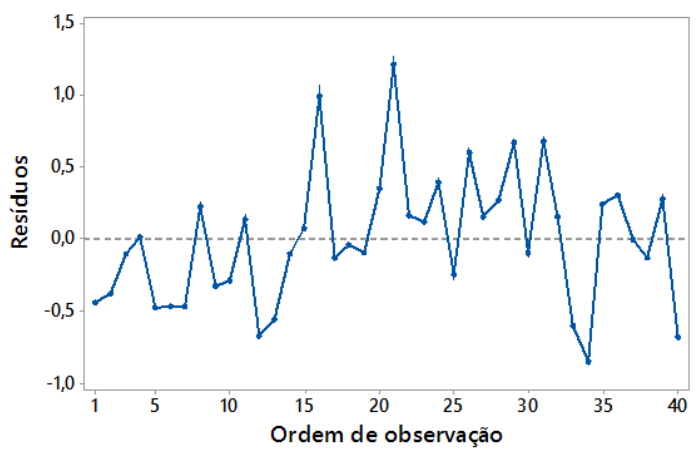

(d)

Fonte: Marcia Cristina Silva, 2018

O histograma (Figura 63(a)) e o papel de probabilidade (Figura 63(b)) demonstram a dispersão e distribuição dos resíduos e juntamente com teste de normalidade Anderson-Darling com valor de p (p-value) igual a 0,625. Para valor de $p$ (p-value) maior que 0,05 a hipótese nula é aceita, indicando que os resíduos apresentam distribuição normal.

A Figura 63(c) demonstra graficamente que a variância dos resíduos apresenta igualdade. Também foi possível verificar a independência dos resíduos (Figura 63(d)), não apresentando comportamento sistemático, sem indício de influência externa ao experimento.

Para a confirmação de que os resíduos apresentam igualdade de foi realizado o teste de igualdade de variância Bartlet, resultando em valor de p (p-value) igual a 0,990. Para valor de $\mathrm{p}$ (p-value) maior que 0,05 a hipótese nula é aceita, indicando que os resíduos apresentam igualdade de variância. Também foi possível ilustrar tal igualdade graficamente, conforme demonstrado na Figura 64. 
Figura 64 - Teste de Bartlett para Análise de Variância dos resíduos relacionando a variável resposta "velocidade de queima" com a variável explicativa "material" no grupo de dados relativos ao "ligamento tela, direção urdume"

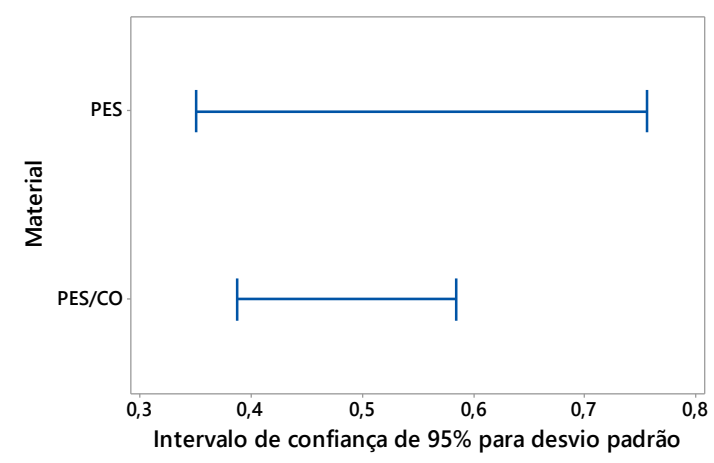

Fonte: Marcia Cristina Silva, 2018.

Na Figura 64, é possível verificar a sobreposição das médias dos resíduos com os respectivos intervalos de confiança, confirmando a igualdade de variância.

A análise dos resíduos, juntamente com a ANOVA com valor de $\mathrm{p}$ ( $\mathrm{p}$-value) menor que 0,05 a hipótese nula é rejeitada em favor da hipótese alternativa de que as médias da variável resposta "velocidade de queima" relacionada com a variável explicativa "material" no grupo de dados relativos à "ligamento tela, direção urdume".

Para determinação do melhor tratamento, o qual para este estudo trata-se daquele que apresenta menor média para velocidade de queima, foi realizado o teste de múltiplas comparações com o melhor, proposto por Hsu. O resultado pode ser observado na Figura 65.

Figura 65 - Teste de múltiplas comparações de HSU relacionando a variável resposta "velocidade de queima" com a variável explicativa "material" no grupo de dados relativos ao "ligamento tela, direção urdume".

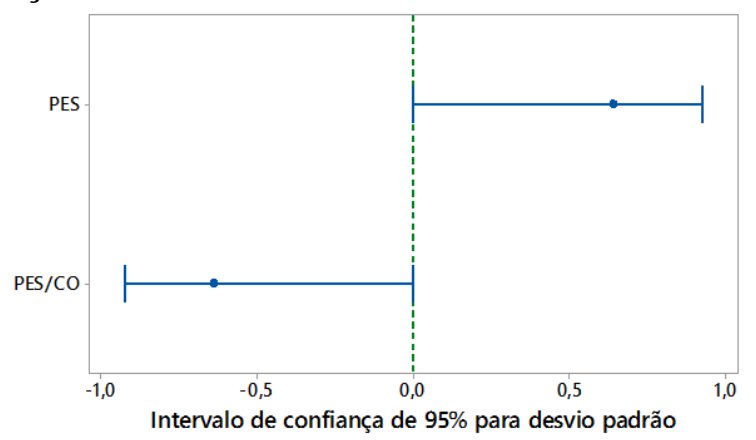

Fonte: Marcia Cristina Silva, 2018.

O intervalo de confiança criado pelo teste de Hsu, o qual demonstra a diferença entre cada média de velocidade de queima com a melhor das médias, apresentam 
intervalos com zero como ponto final, evidenciando que existe uma diferença estatisticamente significativa entre as médias correspondentes. O intervalo de confiança referente ao material $67 \% \mathrm{PES} / 33 \% \mathrm{CO}$ possui grande parte dos valores negativos, portanto, pode-se dizer que ele é o melhor entre os demais.

Com este valor menor que $\alpha$ de 0,05 a hipótese nula é rejeitada e as médias da variável resposta "velocidade de queima" com relação a variável explicativa "material" entre grupo de "ligamento tela, direção urdume" são consideradas estatisticamente diferente para os materiais 100\% PES e $67 \% \mathrm{PES} / 33 \% \mathrm{CO}$.

\subsubsection{Síntese da Análise Estatística}

Com o objetivo de facilitar a visualização das diversas análises das três variáveis explicativas (“direção", "material”, "ligamento") com a variável resposta "velocidade de queima”, por meio de agrupamento dos resultados originados dos testes físicos realizados nos tecidos com afinidades específicas, ou seja especificações técnicas semelhantes, os valores sumarizados encontram-se na Tabela 6.23. 
Tabela 6. 23 - Resumo da análise estatística para variável resposta "velocidade de queima” com relação as três variáveis explicativas ("direção", "material”, "ligamento").

\begin{tabular}{|c|c|c|c|c|c|c|c|c|c|c|c|}
\hline \multirow{2}{*}{\multicolumn{4}{|c|}{ Grupo de variáveis explicativas }} & \multirow{3}{*}{ ANOVA } & \multicolumn{4}{|c|}{ Validação } & \multirow{3}{*}{$\begin{array}{c}\text { Kruskal- } \\
\text { Wallis }\end{array}$} & \multirow{3}{*}{$\begin{array}{l}\text { Variável } \\
\text { explicativa }\end{array}$} & \multirow{3}{*}{$\begin{array}{c}\text { Resultado } \\
\text { (menor velocidade de } \\
\text { queima) }\end{array}$} \\
\hline & & & & & \multicolumn{4}{|c|}{$\mathrm{p}$-value } & & & \\
\hline & & & & & A.D & Bartlet & Levene & Bonett & & & \\
\hline \multirow{7}{*}{ 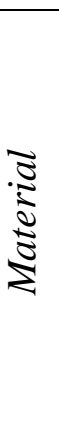 } & $100 \% \mathrm{CO}$ & & Sarja & 0,775 & 0,881 & 0,7308 & 0,474 & 0,706 & & \multirow{7}{*}{ Direção } & Iguais \\
\hline & $100 \% \mathrm{PES}$ & & Sarja & 0,000 & 0,573 & 0,832 & 0,688 & 0,811 & & & Urdume \\
\hline & $100 \%$ PES & & Tela & 0,000 & 0,077 & 0,753 & 0,742 & 0,823 & & & Trama \\
\hline & $67 \%$ PES & $\stackrel{2}{5}$ & Sarja & 0,121 & 0,928 & 0,156 & 0,131 & 0,114 & & & Iguais \\
\hline & $133 \% \mathrm{CO}$ & है & & & & & & & & & \\
\hline & $67 \%$ PES & $\stackrel{\infty}{*}$ & Tela & 0,285 & 0,105 & 0,548 & 0,165 & 0,723 & & & Iguais \\
\hline & $\begin{array}{l}50 \% \mathrm{WO} / \\
50 \% \mathrm{PES}\end{array}$ & & Tela & 0,888 & 0,909 & 0,757 & 0,747 & 0,782 & & & Iguais \\
\hline \multirow{4}{*}{ 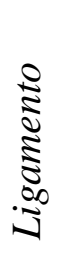 } & Sarja & & Trama & 0,000 & 0,115 & 0,004 & 0,059 & 0,041 & - & \multirow{4}{*}{ Material } & $100 \% \mathrm{CO}$ \\
\hline & Sarja & 8 & Urdume & 0,000 & 0,054 & 0,000 & 0,003 & 0,002 & 0,000 & & $100 \% \mathrm{CO}$ \\
\hline & Tela & $\stackrel{\bar{\pi}}{2}$ & Trama & 0,270 & 0,018 & 0,475 & 0,486 & 0,717 & 0,090 & & Iguais \\
\hline & Tela & & Urdume & 0,001 & 0,625 & 0,990 & 0,561 & 0,990 & - & & $67 \% \mathrm{PES} / 33 \% \mathrm{CO}$ \\
\hline
\end{tabular}

Fonte: Marcia Cristina Silva, 2018 
A variável explicativa "direção" apresenta dois níveis: trama e urdume. O comportamento da variável explicativa "direção" sobre a variável resposta "velocidade de queima" resultou em valores estatísticamente iguais para trama e urdume para os grupos de "material 100\% CO, ligamento sarja", "67\%PES/33\%CO, ligamento sarja", "67\%PES/33\% CO, ligamento tela" e "50\%WO/50\%PES, ligamento tela" (Tabela 6.25).

Já para os grupos correspondentes ao material poliéster (100\% PES), para o ligamento sarja, o valor para "velocidade de queima" foi menor na direção do urdume e para o ligamento tela, a menor velocidade foi observada na direção da trama. Este resultado pode ser explicado pela maior densidade linear do fio de trama $(13,67 \pm 0,54$ tex $)$ , gramatura ligeiramente menor e maior número de fios do grupo "material 100\% PES, ligamento tela".

Os resultados para a variável explicativa "material" sobre a variável resposta "velocidade de queima" resultou em valores estatísticamente iguais para trama e urdume para os grupos de "material 100\% CO, ligamento sarja", "67\% $\mathrm{PES} / 33 \% \mathrm{CO}$, ligamento sarja", "67\%PES/33\% CO, ligamento tela" e "50\%WO/50\%PES, ligamento tela".

Após os agrupamentos, a variável explicativa "material" apresentou três níveis: $100 \%$ CO, 100\%PES, 67\%PES/33\%CO. Para o grupo "ligamento tela,direção trama" a média de velocidade de queima apresentou igualdade para os materiais 100\% PES e $67 \% \mathrm{PES} / 33 \% \mathrm{CO}$.

Os resultados para os grupos "ligamento sarja, direção trama" e "ligamento sarja, direção urdume" apresentou diferentes resultados para médias de "velocidade de queima" para os materiais $100 \% \mathrm{CO}, 100 \% \mathrm{PES}, 67 \% \mathrm{PES} / 33 \% \mathrm{CO}$. O material com menor valor de "velocidade de queima" foi o 100\%CO e em seguida o 67\%PES/33\%CO. Tal comportamento pode ser explicado pela mistura das fibras de algodão com fibras de poliéster.

\subsubsection{Digital Scanning Calorimetry (DSC):}

Por fim, o ensaio DSC foi realizado, com temperatura de ensaio de $0^{\circ} \mathrm{C}$ a $450^{\circ} \mathrm{C}$, com velocidade de aquecimento de $10^{\circ} \mathrm{C} / \mathrm{min}$, o que resultou nos gráficos apresentados na Figura 77 e visualizar o comportamento do material 100\% CO e 67\%/33\% CO, quando submetido ao quecimento. 
Figura 66 - Curvas DSC para (a) T1(100\%CO) e (b) T2 (67\%PES/33\%CO).Velocidade de aquecimento $10^{\circ} \mathrm{C} / \mathrm{min}$.

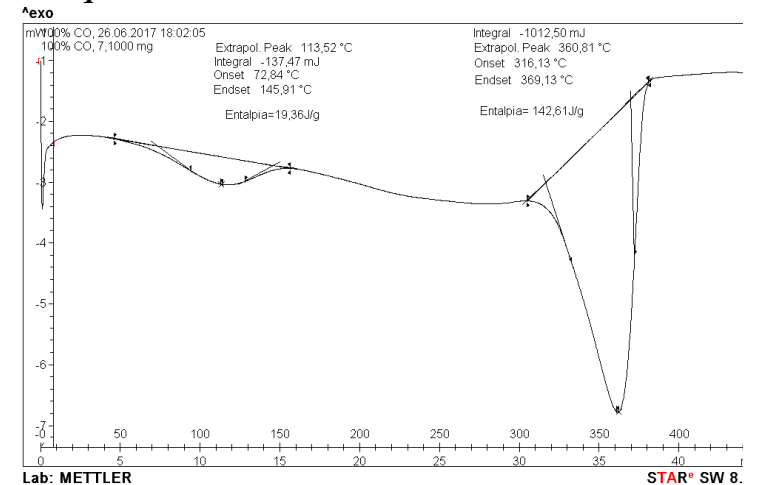

(a)

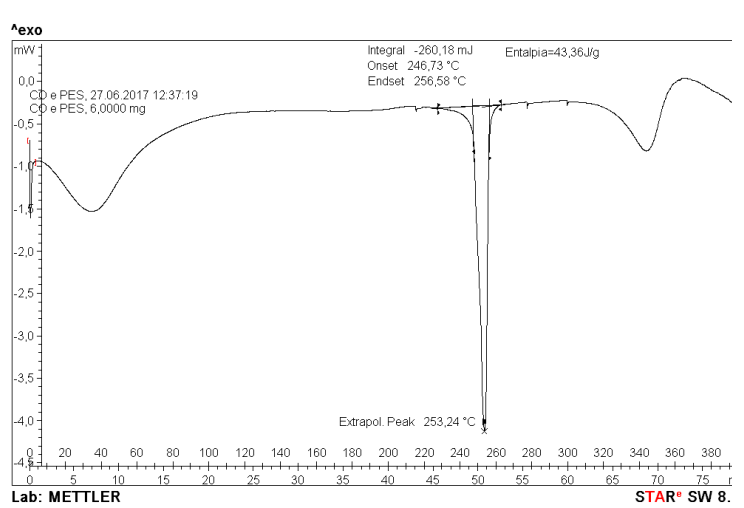

(b)

Fonte:Departamento de Engenharia Têxtil, UMINHO(2017)

A calorimetria exploratória diferencial (DSC) é utilizada para medir a diferença de energia entre uma amostra e um material de referência em função de um programa de aquecimento ou resfriamento sob atmosfera controlada.

Para T1(a) a primeira variação de entalpia endotérmica (19,36 J/g) ocorre com a perda de massa devido a vaporização da água, formando o pico de $113,52^{\circ} \mathrm{C}$ com temperatura inicial (on set) de $72,84^{\circ} \mathrm{C}$ e temperatura final (end set) de $145,91^{\circ} \mathrm{C}$. Prosseguindo com o programa de aquecimento a última variação de entalpia endotérmica $(142,61 \mathrm{~J} / \mathrm{g})$ da amostra ocorre degradação da celulose, formando o pico de $360,81^{\circ} \mathrm{C}$ com temperatura inicial (on set) de $316,13^{\circ} \mathrm{C}$ e temperatura final (end set) de $369,13^{\circ} \mathrm{C}$.

Para T2(b) a variação de entalpia endotérmica (43,36 J/g) ocorre a degradação do poliéster, formando o pico de $253,24^{\circ} \mathrm{C}$ com temperatura inicial (on set) de $246,73^{\circ} \mathrm{C}$ e temperatura final (end set) de $256,58^{\circ} \mathrm{C}$. A pequena fração de algodão nos tecidos, não foi suficiente para apresentar os seus picos característicos.

\subsubsection{STA (Simultaneous Thermogravimetric analysis)}

O ensaio foi realizado em equipamento STA 7000 (Hitachi) com Nitrogênio a temperatura de ensaio de $30^{\circ} \mathrm{C}$ a $600^{\circ} \mathrm{C}$ e com $10^{\circ} \mathrm{C} / \mathrm{min}$ de velocidade de aquecimento, o que resultou nos gráficos apresentados na Figura 78 . 
Figura 67 - Curvas STA para (a) T1(100\%CO) e (b) T2 (67\%PES/33\%CO).Temperatura de $30^{\circ} \mathrm{C}$ a $600^{\circ} \mathrm{C}$ e velocidade de aquecimento $10^{\circ} \mathrm{C} / \mathrm{min}$.

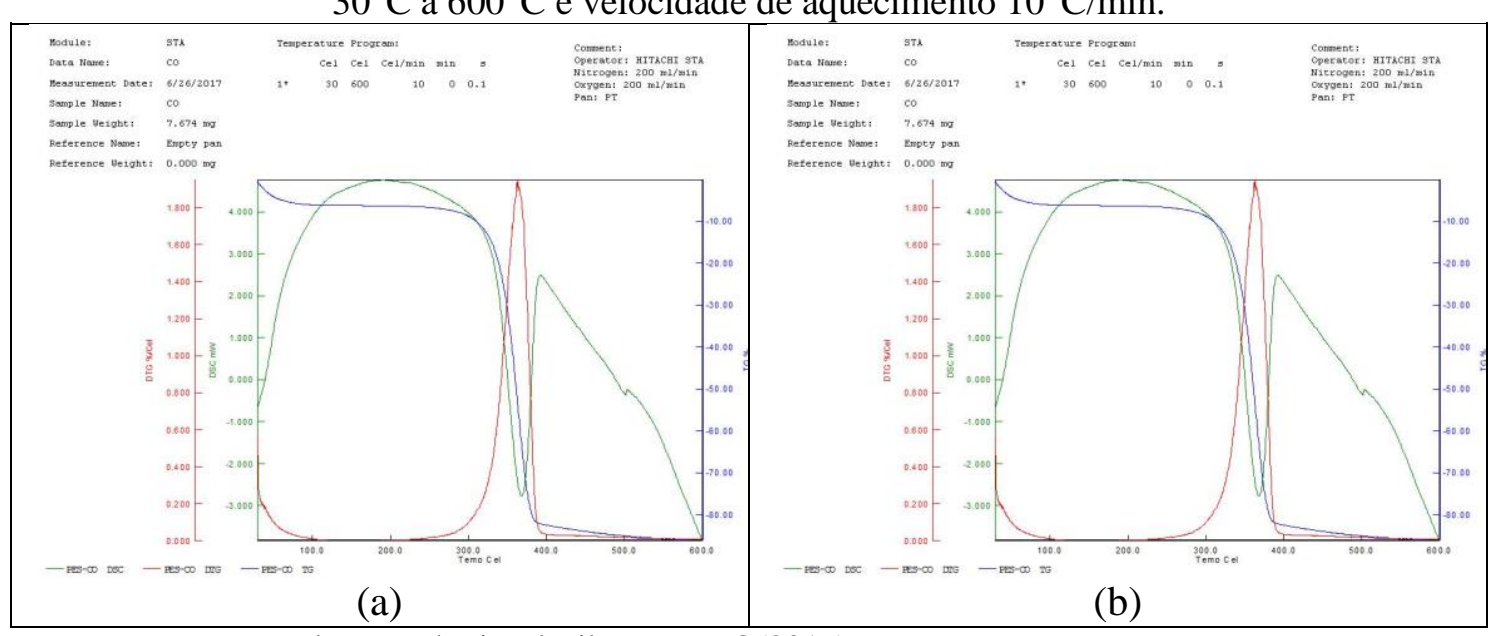

Fonte:Departamento de Engenharia Têxtil, UMINHO(2017)

Dada curva termogravimétrica de T1(100\% CO) (a), é possível observar pequenas mudanças de massa na faixa de $100^{\circ} \mathrm{C}$, mantendo-se até a temperatura de $360^{\circ} \mathrm{C}$, quando se inicia a degradação do material e a redução acelerada da massa até restar os resíduos.

Dada curva termogravimétrica de T2 (67\%PES/33\%CO) (b), é possível observar pequenas mudanças de massa na faixa de $300^{\circ} \mathrm{C}$, mantendo-se até a temperatura de $400^{\circ} \mathrm{C}$, quando se inicia a degradação do material e a redução acelerada da massa até restar os resíduos.

Tais apresentações corroboram com a análise de que material com menor valor de "velocidade de queima" foi o $100 \% \mathrm{CO}$ e em seguida o $67 \% \mathrm{PES} / 33 \% \mathrm{CO}$. A mudança de massa no material $100 \% \mathrm{CO}$ ocorre na faixa de $100^{\circ} \mathrm{C}$ a $360^{\circ} \mathrm{C}$ 


\section{CONSIDERAÇÕES FINAIS}

As aplicações de materiais têxteis são amplas em diversos setores, incluindo na indústria aeronáutica. Nesta área, todo o uso do material têxtil em cabine de aeronaves é regulamentado para minimizar os riscos inerentes às operações de voo, incluindo a resistência á chamas.

O uniforme evoluiu de instrumento de padronização para uma forma de comunicação visual dos valores das organizações. É ideal que proporcione conforto e facilite a adequação ao ambiente de trabalho. As Linhas Aéreas valorizam a importância do uso de uniforme fazendo com que a imagem dos funcionários seja aderente ao negócio, pois o uniforme traduz os valores que a empresa deseja expressar. Tais informações visam a apresentação da empresa junto ao público, a imagem corporativa e seus objetivos comerciais.

Para os materiais têxteis utilizados na cabine de passageiros das aeronaves tais como revestimento do piso, tecidos das cortinas, cobertura de assentos entre outros, é requerido que o material seja auto extinguível, aprovado no teste de chama vertical de acordo com a normativa FAR 25.

A qualificação do material consiste em submeter o corpo de prova a uma chama controlada por 10 segundos. Após a remoção da chama, é medido o tempo em que o material continua queimando e observados eventuais gotejamentos. O material somente é qualificado para utilização na cabine de passageiros de uma aeronave, se o comprimento de tecido queimado após retirada a chama não exceder $200 \mathrm{~mm}$ em até no máximo 15 segundos. Também não pode apresentar gotejamento por mais de 3 segundo após retirada a chama. No presente estudo, foi observado que nenhum dos materiais têxteis utilizados em uniformes de aeronautas se enquadram nesses critérios.

Apesar de ocorrer com frequência muito baixa, os eventos com fogo a bordo são combatidos pelos Comissários de Voo, profissionais que recebem o treinamento adequado para sua ação como agentes de segurança durantes os voos, vestidos em seus uniformes, cuja escolha do material não segue a mesma qualificação do têxtil utilizados nas cabines das aeronaves.

Um material com menor velocidade de queima, para estes profissionais treinados para o combate de fogo a bordo, a diferença no tempo para a retirada de uma vestimenta em chamas pode significar a manutenção de sua integridade física e o cumprimento de suas atribuições como agentes de segurança a bordo ao final da ocorrência. 
As roupas profissionais são geralmente feitas de poliéster ou com suas misturas com algodão, por se tratarem de materiais relativamente baratos para a indústria de vestuário e proporcionam o conforto e respirabilidade do algodão com a força e durabilidade do poliéster. No entanto estas fibras e misturas apresentam baixa estabilidade térmica e alta velocidade de queima.

Outro conceito importante para o entendimento desta abordagem é a inflamabilidade, ou a capacidade de um tecido para inflamar e manter a chama, e como se torna uma constante preocupação com a segurança, a ponto de alguns países emitirem leis para reduzir o risco de ferimentos tecidos inflamáveis.

A redução da inflamabilidade pode ser obtida com o uso de tecidos inerentemente retardantes de chamas, tecidos com retardantes de chamas incorporados em suas fibras e acabamentos com os diversos tipos de retardantes de chamas disponíveis no mercado.

Os tecidos constituídos de fibras inerentemente retardantes de chamas mais conhecidos são o Nomex ${ }^{\circledR}$ e o Kevlar ${ }^{\circledR}$, aplicados em uniformes de bombeiros e até peças do uniforme de pilotos da Fórmula I. As cortinas das galleys da cabine das aeronaves são confeccionadas com o tecido produzidos com a fibra Trevira CS, com retardante de chamas aplicado em sua estrutura, proporcionando ao produto final a retardância de chamas permanente. Ambos tecidos com gramatura pesada, característica maior que as encontras nas peças de uniforme atualmente utilizadas pelos aeronautas.

A outra alternativa se apresenta com o uso de tecidos com gramatura adequada à confecção de camisas, calças ou casacos como exemplo de peças de uniforme, com a aplicação de retardantes de chamas, na etapa de acabamento. Esta é uma opção que necessita de cuidado com os produtos químicos que serão aplicados, pois alguns retardantes de chamas liberam substâncias tóxicas prejudiciais à saúde durante o uso (BEEN; BASTIAENSEN; LAI; LIBOUSI; THOMAIDIS; BENAGLIA; ESSEIVA; DELE; NUIJS; COVACI, 2018; BEEN; BASTIAENSEN; LAI; LIBOUSI; THOMAIDIS; BENAGLIA; ESSEIVA; DELE; NUIJS; COVACI; et al., 2018; KHAIRY; LOHMANN, 2018).

Este tipo de tratamento é chamado não durável. A cada lavagem da peça, o produto se desprende e retorna à condição original. Também é necessário verificar as características de toque e caimento do tecido, podendo torna-se mais rígido e não atender as necessidades para a confecção de peças de alfaiataria para uniformes. 
Fan e Lau (2009) consideram a influência do material têxtil no mecanismo de queima participando como duas componentes do quadrilátero do fogo: o combustível e o comburente (oxigênio). O tipo de fibra, tal como a sua composição química e a possível aplicação de acabamentos retardantes de chamas desempenham papéis importantes como combustível. Já a estrutura do tecido, representada por seu ligamento, densidade de fios, fator de cobertura e gramatura sinalizam a razão do ar/oxigênio na superfície do tecido e sua ação como comburente.

Desta forma, os tecidos usados na confecção de uniformes de aeronautas foram caracterizados em suas propriedades físicas e submetido à teste de inflamabilidade para verificação da velocidade de queima.

Para a realização dos teste de inflamabilidade, foi desenvolvida a Cabine USP, para atender os requisitos das normas 16CFR Part 1610:2018 - Standard for flammability of clothing textile; ISO 6940:2004 - Textile Fabrics - Burning behaviour Determination of ease of ignition of vertically oriented specimens; ISO 6941:2003 Textile Fabrics - Burning behaviour-Measument of flame spread properties of vertically oriented specimens e NF G07-182 - Textiles - Comportement au feu - Détermination des propriétés de propagation de flamme sur éprouvettes orientées à 45 degrés - Mesurage de la vitesse de propagation de flamme.

A construção de uma cabine de teste própria se fez pela especificidade das amostras de pequenas dimensões, a priorização na medição da velocidade de queima e a quantidade de amostras testadas, totalizando a duzentos ensaios.

Com uma grande quantidade de dados obtidas, foi conduzida as análises estatísticas e foi possível estabelecer as correlações entre as variáveis dos tecidos e a velocidade de queima.

A melhor combinação representa a menor velocidade de queima. Este marco foi

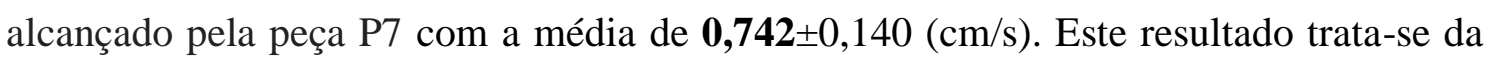
média obtida da velocidade de queima das 10 amostras ensaiadas do tecido de calça masculina, na direção da trama. A composição da peça é uma mistura de $55 \% \mathrm{PES} / 45 \%$ WO com gramatura de $\mathbf{2 2 5 , 1 2} \pm 5,02\left(\mathrm{~g} / \mathrm{m}^{2}\right)$, densidade linear do fio de $\mathbf{3 6 , 6 1} \pm 1,48$ (tex) e torção de $\mathbf{5 9 8 , 0 0 \pm 4 5 , 3 4 ( t o r c ̧ o ̃ e s ~} / \mathrm{m}$ ). O diâmetro do fio calculado pelo modelo de Peirce é de $\mathbf{0 , 2 1 9} \mathrm{mm}$.

A análise de variância com todos os fatores, não foi validada pela análise dos resíduos., entretanto a verificação da relação entre as variáveis explicativas "direção", "material" e "ligamento" com a variável resposta "velocidade de queima" realizada com 
o agrupamento por características físicas específicas, resultou em análises validadas por seus resíduos.

(i) Influência da "direção" na "velocidade de queima" :

a. Grupo "material 100\% CO, ligamento tela", a velocidade de queima é estatisticamente igual na direção de trama e urdume.

b. Grupo "material 100\% PES, ligamento sarja", a velocidade de queima é estatisticamente diferente, sendo menor na direção da trama.

c. Grupo "material 100\% PES, ligamento tela", a velocidade de queima é estatisticamente diferente, sendo menor na direção do urdume.

d. Grupo "material 67\% PES/33\% CO, ligamento sarja" e "material 67\% PES/33\% CO, ligamento tela", a velocidade de queima é estatisticamente igual na direção de trama e urdume.

e. Grupo "material 50\% WO/50\% PES, ligamento tela", a velocidade de queima é igual na direção de trama e urdume.

(ii) Influência da "composição" na "velocidade de queima":

a. Grupo "ligamento sarja, direção trama" a velocidade de queima é estatisticamente diferente, sendo menor para a composição algodão (100\% CO).

b. Grupo " ligamento sarja, direção urdume" a velocidade de queima é estatisticamente diferente, sendo menor para a composição algodão (100\% CO).

c. Grupo "ligamento tela, direção trama" a velocidade de queima é estatisticamente igual para composição 100\%CO, 100\%PES, $67 \% \mathrm{PES} / 33 \% \mathrm{CO}$ e $50 \% \mathrm{WO} / 50 \% \mathrm{PES}$.

d. Grupo " ligamento tela, direção urdume a velocidade de queima é estatisticamente igual para composição $67 \% \mathrm{PES} / 33 \% \mathrm{CO}$.

Portanto, ainda que ainda com resultados encontrados no presente estudo estarem abaixo dos preconizados pela FAR25, é possível pensar em futuros experimentos em sentido de diminuir a inflamabilidade dos tecidos dos uniformes dos aeronautas e outros uniformes de uso profissional levando em conta a combinação de características físicas do material têxtil, tais como: 
(i) construções mais fechadas de tecidos, com distância mínima entre os fios, aumentando o fator de cobertura e diminuindo o oxigênio que circula nos interstícios do tecido;

(ii) construção de tecidos de fibras naturais de origem vegetal ou animal ou misturas com fibras sintéticas para agregar funcionalidade, sendo que tais fibras sintéticas podem ter alguma aditivação retardante de chamas. Os ensaios demonstraram que a resposta de velocidade de queima não é proporcional às quantidades de diferentes de fibras;

(iii) Mudança da direção do tecido empregado na confecção dos uniformes, uma vez que a velocidade de queima é menor na direção da trama. Deste modo, variações na modelagem das roupas (por exemplo, corte reto ou de viés) poderia estar relacionada a alguma alteração na inflamabilidade (velocidade de queima) do uniforme. Ainda uma modelagem melhor estudada (além da questão estética) poderia ajudar a proteger o corpo dos aeronautas de eventuais acidentes envolvendo inflamabilidade;

(iv). Estudar alterações na gramatura e torção dos seus fios constituintes, já que a composição dos tecidos tem dependência com essas variáveis, as quais contribuem para a massa de combustível disponível para queima. 


\section{CONCLUSÕES}

O presente estudo analisou as características têxteis que influenciaram a velocidade de queima dos tecidos usados na confecção de uniformes de aeronautas (número de fios de trama; número de fios de urdume; fator de cobertura; torção; gramatura; espessura; diâmetro do fio; densidade linear; ligamento; composição; direção trama ou urdume).

Desta forma, experimentos de queima de material têxtil, retirados de peças de uniformes de aeronautas doadas, foram realizados em cabine customizada para as características dos ensaios, os quais empregaram amostras de tecidos de pequenas dimensões.

Os resultados encontrados no presente estudo não se enquadram nos limites preconizados pela FAR25 para que o material seja qualificado auto extinguível.

Para os tecidos avaliados no teste de inflamabilidade o menor valor encontrado foi de média de $\mathbf{0 , 7 4 2} \pm 0,140(\mathrm{~cm} / \mathrm{s})$. Este resultado trata-se da média obtida da velocidade de queima das 10 amostras ensaiadas do tecido da peça P7 (calça masculina) na direção da trama. A composição da peça é uma mistura de $50 \%$ lã e 50\% poliéster com gramatura de $\mathbf{2 2 5 , 1 2} \pm 5,02\left(\mathrm{~g} / \mathrm{m}^{2}\right)$, densidade linear do fio de $\mathbf{3 6 , 6 1} \pm 1,48$ (tex) e torção de $\mathbf{5 9 8 , 0 0 \pm 4 5 , 3 4 ( t o r c ̧ o ̃ e s ~} / \mathrm{m}$ ). O diâmetro do fio calculado pelo modelo de Peirce foi de $\mathbf{0 , 2 1 9}$ $\mathrm{mm}$.

No outro extremo, o maior valor encontrado foi $\mathbf{3 , 6 9 8} \pm 1,806(\mathrm{~cm} / \mathrm{s})$. Este resultado trata-se da média obtida da velocidade de queima das 10 amostras ensaiadas do tecido da peça P5 (camisa masculina) na direção da trama. A composição da peça é uma mistura de $67 \%$ poliéster e $33 \%$ algodão com gramatura de $\mathbf{1 0 8 , 7 2} \pm 2,39\left(\mathrm{~g} / \mathrm{m}^{2}\right)$,

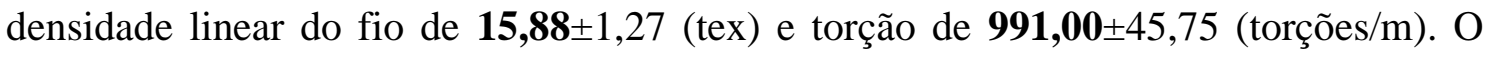
diâmetro do fio calculado pelo modelo de Peirce foi de $\mathbf{0 , 1 4 8} \mathrm{mm}$.

A análise de variância com todos os fatores, não foi validada pela análise dos resíduos., entretanto a verificação da relação entre as variáveis explicativas "direção", "material" e "ligamento" com a variável resposta "velocidade de queima" realizada com o agrupamento por características físicas específicas, resultou em análises validadas por seus resíduos.

(iii) Influência da "direção" na "velocidade de queima":

a. Grupo "material 100\% CO, ligamento tela", a velocidade de queima é estatisticamente igual na direção de trama e urdume. 
b. Grupo "material 100\% PES, ligamento sarja", a velocidade de queima é estatisticamente diferente, sendo menor na direção da trama.

c. Grupo "material 100\% PES, ligamento tela", a velocidade de queima é estatisticamente diferente, sendo menor na direção do urdume.

d. Grupo "material 67\% PES/33\% CO, ligamento sarja" e "material 67\% $\mathrm{PES} / 33 \% \mathrm{CO}$, ligamento tela", a velocidade de queima é estatisticamente igual na direção de trama e urdume.

e. Grupo "material 50\% WO /50\% PES, ligamento tela", a velocidade de queima é igual na direção de trama e urdume.

(iv) Influência do "material" na "velocidade de queima":

a. Grupo "ligamento sarja, direção trama" a velocidade de queima é estatisticamente diferente, sendo menor para a composição algodão (100\%CO).

b. Grupo " ligamento sarja, direção urdume" a velocidade de queima é estatisticamente diferente, sendo menor para a composição algodão (100\%CO).

c. Grupo "ligamento tela, direção trama" a velocidade de queima é estatisticamente igual para composição 100\%CO, 100\%PES, 67\%PES/33\% CO e 50\%WO/50\%PES.

d. Grupo " ligamento tela, direção urdume a velocidade de queima é estatisticamente igual para composição 67\% PES/33\% CO.

Assim sugestões para estudos futuros podem levar em conta construções mais fechadas de tecidos; construção de tecidos com fibras de origem vegetal ou animal ou misturas com fibras sintéticas (com ou sem aditivação de retardantes de chamas) para agregação de funcionalidade; mudanças na modelagem das peças; e estudar alteração na gramatura dos tecidos e da torção dos seus fios constituintes. 


\section{REFERENCIAS 2}

AGÊNCIA NACIONAL DE AVIAÇÃO - ANAC. Anuário de Transporte Aéreo. . Brasilia: ANAC, Agência Nacional de Aviação Civil. , 2016a

RBAC - 121 - Requisitos Operacionais: Operações domésticas de Bandeira

e suplementares. . Brasília: [s.n.]. , 2010

RBHA - 141 - Escolas de Aviação civil. . Brasília: ANAC. , 2016b

RBHA 63 - Requisitos para concessão de licenças de mecânico de vôo e

comissário de vôo. . Brasília: [s.n.]. , 2006

AIRPORTS COUNCIL INTERNATIONAL. WATR 2017 - Annual World Airport Traffic Report. Disponível em: <file:///C:/Users/Marcia Cristina/Downloads/WorldAnnual-Traffic-Report-2017-edition-LowRes.pdf>. Acesso em: 23 jul. 2018.

ALFIERI, Paulo. Tecnologia das Fibras Têxteis III - Apostila. . São Bernardo do Campo: FEI - Departamento de Engenharia Têxtil. , 2011

ALMEIDA, Adilson José. Uniformes da Guarda Nacional (1831- 1852): a indumentária na organização e funcionamento de uma associação armada. Anais do Museu Paulista. São Paulo. N. Sér. v. 8/9. p. 77-147, p. 77-147, 2003.

ANJOS, A. dos et al. Estatística. p. 146, 2009.

ANTONISAMY, B; CHRISTOPHER, Solomon; SAMUEL, P. Prasanna. Biostatistics Principles and Pratice. Nova Delhi: Tata McGraw Hill Education Private Limited, 2010.

ASSOCIAÇÃO BRASILEIRA DA INDUSTRIA TÊXTIL E DE CONFECÇÃO. Perfil do Setor. Disponível em: <http://www.abit.org.br/cont/perfil-do-setor>. Acesso em: 7 jul. 2018a.

Relatório de Atividades 2016. . São Paulo: ABIT, Associação Brasileira da Indústria Têxtil. , 2017b

ASSOCIAÇÃO BRASILEIRA DE NORMAS TÉCNICAS. ABNT NBR ISO 139 Têxteis - Atmosfera padrão para condicionamento e ensaios. . Rio de Janeiro: ABNT. , 2008

ABNT NBR NM ISO 3758:2013 - Têxteis - Códigos de cuidado usando símbolos. . Rio de Janeiro: ABNT. , 2013

NBR 10588:2015 - Tecidos planos - Determinação da densidade de fios. Rio de Janeiro: ABNT, 2015.

NBR 12071:2002 - Artigos Confeccionados para vestuário - Determinação das dimensões. Rio de Janeiro, Brasil: ABNT, 2002.

NBR 12331 - Fibras têxteis - Taxa convencional de condicionamento. . Rio de Janeiro: ABNT. , 1991

NBR 12996:1993 - Materiais têxteis - Determinação dos ligamentos

\footnotetext{
${ }^{2}$ De acordo com a Associação Brasileira de Normas Técnica. NBR 6023 (2002).
} 
fundamentais de tecidos planos. Rio de Janeiro, Brasil: ABNT, 1993.

NBR 13371:2005 - Materiais têxteis - Determinação da espessura. Rio de Janeiro: ABNT, 2005.

ASSOCIATION FRANÇAISE DE NORMALISATION - AFNOR. NF G07-182 Textiles - Comportement au feu - Détermination des propriétés de propagation de flamme sur éprouvettes orientées à 45 degrés - Mesurage de la vitesse de propagation de flamme. . [S.l: s.n.]. , 1985

ATREYA, Arvind. Convection Heat Transfer. SFPE - Handb. Fire Prot. Eng. [S.1.]: National Fire Protection Association, 2002. p. 1604.

ATTIA, Nour F.; MORSY, Mahmoud S. Facile synthesis of novel nanocomposite as antibacterial and flame retardant material for textile fabrics. Materials Chemistry and Physics, v. 180, p. 364-372, 2016.

B FONSECA, Priscila Fleming. A DISCIPLINA JURÍDICA DA UTILIZAÇÃO DE INDUMENTÁRIA NO AMBIENTE DE TRABALHO E A IMAGEM DO EMPREGADO. Direito UNIFACS-Debate Virtual, v. 164, 2014.

BAJAJ, Pushpa. Heat and Flame Protection. In: HARROCKS, A.R.; ANAND, Subhash C. (Org.). . Handb. Tech. Text. Cambridge: Woodhead Publishing Limited Abington Hall, 2000. p. 559.

BARRETI, Bozzo; PRETO, Dinho Ouro. Fogo. Você Precisa Entender. Rio de Janeiro: [s.n.]. , 1988

BASTIAN, Elza Y. Onishi; ROCCO, Jorge Luiz Silva. Guia Técnico Ambiental da Indústria Têxtil. São Bernardo do Campo: CETESB/ SINDITÊXTIL, 2009.

BEEN, Frederic; BASTIAENSEN, Michiel; LAI, Foon Yin; LIBOUSI, Katerina; THOMAIDIS, Nikolaos S; BENAGLIA, Lisa; ESSEIVA, Pierre; DELE, Olivier; NUIJS, Alexander L N Van; COVACI, Adrian; et al. Chemosphere Legacy and emerging brominated $\mathrm{fl}$ ame retardants in China : A review on food and human milk contamination, human dietary exposure and risk assessment. Chemosphere, v. 198, p. 1536-1548, 2018.

. Mining the Chemical Information on Urban Wastewater: Monitoring Human Exposure to Phosphorus Flame Retardants and Plasticizers. Environ. Sci. Technol., v. 52, p. 6996-7005, 2018.

BEHERA, B.K.; HARI, P.K. Woven Textile Structure - Theory and Applications. Cambridge: Woodhead Publishing, 2010.

BEYLER, Craig L.; HIRSCHLER, Marcelo M. Thermal Decomposition of Polymer. SFPE - Handb. Fire Prot. Eng. Quincy: National Fire Protection Association, 2002. p. 110.

BOURBIGOT, S. Flame retardancy of textile: new aproaches. In: HORROCKS, a.R.; PRICE, D. (Org.). . Adv. fire Retard. Mater. Cambridge: Woodhead Publishing Limited Abington Hall, 2008. p. 625.

BRASIL, Ministério Do Trabalho E Emprego. Norma Regulamentadora - NR 6 EQUIPAMENTO DE PROTEÇÃO INDIVIDUAL - EPI. . Brasília: [s.n.]. , 2015 
INSTALAÇÕES E SERVIÇOS EM ELETRICIDADE. . Brasília: [s.n.]. , 2016a NORMA REGULAMENTADORA NR 9 - PROGRAMA DE PREVENÇÃO DE RISCOS AMBIENTAIS. . Brasília: [s.n.]. , 2016b

BYRNE, Chris. Technical textiles market - an overview. In: HORROCKS, A.Richard; ANAND, Subhash C. (Org.). . Handb. Tech. Text. Cambridge: Woodhead Publishing Limited Abington Hall, 2000. p. 559.

CAI, Guangming et al. A new apparatus to measure the effect of temperature and light on the bending fatigue properties of Kevlar 49 and PBO fibers. Polymer Testing, v. 40, p. 143-148, 2014.

CANAL, C.; GINEBRA, M. P. Fibre-reinforced calcium phosphate cements: A review. Journal of the Mechanical Behavior of Biomedical Materials, v. 4, n. 8, p. 16581671, 2011.

CASTELLITTI, Carolina. Corpo e disciplina na carreira de comissária de bordo na Varig. 2014, [S.1: s.n.], 2014. p. 1-16.

CHAE, Han Gi; KUMAR, Satish. Rigid-rod polymeric fibers. Journal of Applied Polymer Science, v. 100, n. 1, p. 791-802, 2006.

CINTRA, Natália Manso; MACHADO, Humberto Cesar. A representação social dos aspectos comportamentais e legais na Aviação Geral. Revista Conexão SIPAER, p. 412, 2016.

COOK, J.Gordon. Handbook of Textile Fibres - Vol I - Natural Fibres. 5. ed. Cambridge: Woodhead Publishing Limited Abington Hall, 2001.

COSTA, Joaquim Nunes da et al. Padrões Universais para Classificação do Algodão 1. . Campina Grande, PB: Empresa Brasileira de Pesquisa Agropecuária, Centro Nacional de Pesquisa de Algodão. , 2006

CRAIK, Jennifer. Uniforms Exposed: The proliferation of uniforms in popular culture as markers of change and identity. In: MENTGES, Gabriele; NEULAND-KITZEROW, Dagmar; RICHARD, Birgit (Org.). . Uniformierrungen Bewegung Vestim. Prakt. zwischen. Vereinheitlichung, Kostumierung makerade. Munster: Waxmann Verlog, 2007. p. 37-55.

DANCEY, Christiane P.; REIDY, John. Estatística sem matemática para psicologia: usando o SPSS para windows. 3. ed. Porto Alegre: Artmed, 2006.

DAVIES, P.; BUNSELL, A. R.; CHAILLEUX, E. Tensile fatigue behaviour of PBO fibres. Journal of Materials Science, v. 45, n. 23, p. 6395-6400, 2010.

DEPAOLI, Marco_Aurélio. Degradação e estabilização de polímeros. [S.1.]:

Chemkeys, 2008.

DOCHIA, M. et al. Cotton Fibres. In: KOZLOWSKI, R.M. (Org.). . Handb. Nat. fibres. Vol. 1 Types, Prop. factors Affect. Breed. Cultiv. Cambridge: Woodhead Publishing Limited Abington Hall, 2012. .

DRYSDALE, Dougal. An introduction to fire dynamics. Chichester, Sussex: John Wiley \& Son LTD, 2011.

DUBOIS, Arthur B. et al. FIRE AND SMOKE : UNDERSTANDING Committee on 
Fire Toxicology. 1986.

DZIUK, Peter; CHAYKA, Katy. Minnesota Wildflowers: a field guide to the flora of Minnesota. Disponível em: <https://www.minnesotawildflowers.info/flower/commonflax>. Acesso em: 28 dez. 2016.

EBEWELE, R O. Polymer Science and Technology. Boca Raton: CRC Press LLC, 2000.

EL MOGAHZY, Y.E. Development of traditional textile fiber products. Eng. Text. Integr. Des. Manuf. Text. Prod. Cambridge: Woodhead Publishing Limited Abington Hall, 2009a. p. 326-397.

Structure, characteristics and types of fiber for textile product design. Eng.

Text. Integr. Des. Manuf. Text. Prod. Cambridge: Woodhead Publishing Limited Abington Hall, 2009b. p. 548.

EL SARRAF, Robert Assad. Aspectos Ergonômicos em Uniformes de Trabalho. 2004. 148 f. Universidade Federal do Rio Grande do Sul, 2004.

ELETRONIC CODE OF FEDERAL REGULATIONS. PART 1610-STANDARD

FOR THE FLAMMABILITY OF CLOTHING TEXTILES. Disponível em:

$<$ https://www.ecfr.gov/cgi-bin/text-

idx?SID=f985415bb8cd50d19a4ea9a104db9d20\&mc=true \&node=pt16.2.1610\&rgn=di v5>. Acesso em: 10 jul. 2018.

EMPRESA BRASILEIRA DE PESQUISA AGROPECUÁRIA - EMBRAPA. Algodão Colorido - BRS Rubi. Disponível em: <https://www.embrapa.br/busca-de-solucoestecnologicas/-/produto-servico/826/algodao-colorido---brs-rubi>. Acesso em: 18 jul. 2018.

ESTATCAMP - CONSULTORIA ESTATÍSTICA; DIGUP - DESENVOLVIMENTO DE SISTEMAS E CONSULTORIA ESTATÍSTICA. Portal Action. Disponível em: <http://www.portalaction.com.br/ambiente-virtual-de-aprendizado>. Acesso em: 31 out. 2018.

FAN, J.; LAU, L. Flammability of Fabrics and Garments. In: FAN, J.; HUNTER, L. (Org.). . Eng. Appar. Fabr. garments. Cambridge: Woodhead Publishing Limited Abington Hall, 2009. p. 413.

FARIAS, Rita de Cássia Pereira. Entre a igualdade e a distinção: A trama social de uma grande empresa corporificada no uniforme. 2010. UNICAMP - Universidade Estadual de Campinas, 2010.

FEDERAÇÃO DAS INDÚSTRIAS ESTADO MINAS GERAIS. GUIA TÉCNICO AMBIENTAL DA INDÚSTRIA TÊXTIL. Belo Horizonte: FIEMG, 2014.

FEDERAL AVIATION ADMINISTRATION. PART 25-AIRWORTHINESS

STANDARDS: TRANSPORT CATEGORY AIRPLANES. Disponível em:

$<$ http://www.ecfr.gov/cgi-bin/text-

idx?SID=1ec3da2a99539ae184e322ac6c4538a8\&mc=true \&node=pt14.1.25\&rgn=div5

>. Acesso em: 9 maio 2016.

FINK, U.; TROITZSCH, J. The market situation. In: TROITZSCH, Dr. Jurgen (Org.). . Plast. Flammabl. Handbook. Princ. Regul. Test. Approv. 3rd Ed. 3rd. ed.

Cincinnati: Hanser Gardener Publications, Inc., 2004. p. 8-32. 
FOOD AND AGRICULTURE ORGANIZATION OF THE UNITED NATIONS FAO. Compare Data. Disponível em: <http://www.fao.org/faostat/en/\#compare>. Acesso em: 18 jul. 2018.

GALLO, Ricardo. Gol cria novos uniformes para tripulação; comessários usarão gravatas. Disponível em:

$<$ https://senhorespassageiros.blogfolha.uol.com.br/2014/03/21/gol-cria-novosuniformes-para-tripulacao-comissarios-usarao-gravata/\#_=_>. Acesso em: 18 jul. 2018.

GAO, Guoxin et al. An excellent ablative composite based on PBO reinforced EPDM. Polymer Bulletin, v. 64, n. 6, p. 607-622, 2010.

GARCÍA, José M. et al. High-performance aromatic polyamides. Progress in Polymer Science (Oxford), v. 35, n. 5, p. 623-686, 2010.

GIL, Antonio Carlos. Como elaborar projetos de Pesquisa. São Paulo: Editora Atlas, 2002.

Métodos e técnicas de pesquisa social. 6. ed. São Paulo: Editora Globo, 2008.

GOMES, Alexandre Castro Leiras. Refino de Petróleo. In: ANTUNES, Adelaide (Org.). . Setores da Indústria Química Orgânica. Rio de Janeiro: E-Papers Serviços Gráficos Ltda, 2007. .

GONG, R.H.; CHEN, X. Technical Yarns. In: HORROCKS, A.Richard; ANAND, Subhash C. (Org.). . Handb. Tech. Text. Cambridge: Woodhead Publishing Limited Abington Hall, 2000. p. 559.

GOUDENHOOFT, Camille; BOURMAUD, Alain; BALEY, Christophe. Conventional or greenhouse cultivation of flax: What influence on the number and quality of flax fibers? Industrial Crops and Products, v. 123, n. November, p. 111-117, 2018.

GRU AIRPORT. RMA: Resumo de Movimentação Aeroportuária. Disponível em: <https://www.gru.com.br/pt/institucional/informacoes-operacionais>. Acesso em: 23 jul. 2018.

GRU AIRPORT CARGO. Estatística. Disponível em:

<http://www.grucargo.com.br/media/30148/Dezembro-2017.pdf>. Acesso em: 23 jul. 2018.

HAIR, J. Cap.1 - Overview of Multivariate Methods.pdf. Multivar. Data Anal. [S.1: s.n.], 2010. .

HALL, Michael. Finishing of technical textile. In: HARROCKS, A.R; ANAND, Subhash C. (Org.). . Handb. Tech. Text. Cambridge: Woodhead Publishing Limited Abington Hall, 2000. p. 559.

HARGRAVE, Harriet. From Fiber to Fabric: The essential guide to Quiltmaking Textiles. Lafayette, CA: C\&T Publishing, INC, 1997.

HARROCKS, A.R.; ANAND, Subhash C. Handbook of Techical Textile. Cambridge: Woodhead Publishing Limited Abington Hall, 2000.

HEARLE, J.W.S. Fibre structure: Its formation and relaton to performance. In:

EICHHORN, S.J. et al. (Org.). . Handb. Text. fibre Struct. Vol. 1 Fundam. Manuf.

Polym. fibres. Cambridge: Woodhead Publishing Limited Abington Hall, 2009. p. 502. 
HORROCKS, A.Richard. Textiles. In: HORROCKS, A.Richard; PRICE, D. (Org.). . Fire Retard. Mater. Cambridge: Woodhead Publishing Limited Abington Hall, 2001. p. 429.

IATA, International Air Transport. Cabin Operations Safety - Best Practices Guide 2015. . Montreal: IATA. , 2015

INFRAERO. Estatísticas. Disponível em: <http://www4.infraero.gov.br/acesso-ainformacao/institucional/estatisticas/>. Acesso em: 23 jul. 2018.

INSTITUTO PORTUGUÊS DA QUALIDADE. IPQ-NP-4114:1991 - Têxteis: tecidos. Construção. Métodos de Análise. Representação do debuxo, da remissa do picado do pente e do comando dos liços. . Lisboa: IPQ. , 1991

INTERNATIONAL ORGANIZATION FOR STANDARDIZATION. ISO 6940 Textile fabrics - Burning behaviour - Determination of ease of ignition of vertically orinted specimens. . Genebra: International Organization for Standardization. , 2004

ISO 7211/1 - Textiles - Woven fabrics - Construction - Methods of analysis - Part 1: Methods for the presentation of a weave diagram and plans for drafting, denting and lifting. . Genebra: International Organization for Standardization. , 1984a

ISO 7211/2 - Textiles - Woven fabrics - Construction - Methods of analysis

- Part 2: Determination of number of threads per unit lenght. . Genebra: International Organization for Standardization. , 1984b

ISO 7211/3 - Textiles - Woven fabrics - Construction - Methods of analysis - Part 3: Determination of crimp of yarn in fabric. . Genebra: International Organization for Standardization. , 1984c

ISO 7211/4 - Textiles - Woven fabrics - Construction - Methods of analysis - Part 4: Determination of twist in yarm removed from fabric. . Genebra: International Organization for Standardization. , 1984d

ISO 7211/5 - Textiles - Woven fabrics - Construction - Methods of analysis - Part 5: Determination of linear density of yarn removed from fabric. . Genebra: International Organization for Standardization. , 1984e

JANSSENS, Marc L. Handbook of Environmental Degradation of Materials. Handbook of Environmental Degradation of Materials, p. 207-225, 2005.

JERÔNIMO, Jeane F et al. Qualidade da semente e fibra de algodão na caracterização do descaroçador de 25 serras 1 . Revista Brasileira de Engenharia Agrícola e Ambiental., v. 18, n. 6, p. 664-671, 2014.

JUNIAC, Alexandre de. Annual Review 2017. Disponível em: <https://www.iata.org/publications/Documents/iata-annual-review-2017.pdf>. Acesso em: 23 jul. 2018.

KASWELL, Ernest R. Wellington Sears Handbook of Industrial Textile. Cambridge: Massachusetts Institute of Technology(MIT) e Wellington Sears Company, 1963.

KHAIRY, Mohammed A; LOHMANN, Rainer. Science of the Total Environment Selected organohalogenated fl ame retardants in Egyptian indoor and outdoor environments : Levels, sources and implications for human exposure. Science of the Total Environment, v. 633, p. 1536-1548, 2018. 
KOZLOWSKI, R.M.; MACKIEWICZ-TALARCZYK, M. Bast Fibres: Flax. In: KOZLOWSKI, R.M. (Org.). . Handb. Nat. fibres. Vol. 1 Types, Prop. factors Affect. Breed. Cultiv. Cambridge: Woodhead Publishing Limited Abington Hall, 2012a. p. 620.

Introduction to Natural textile fibres. In: KOZLOWSKI, R.M. (Org.). . Handb. Nat. fibres. Vol. 1 Types, Prop. factors Affect. Breed. Cultiv. Cambridge:

Woodhead Publishing Limited Abington Hall, 2012b. p. 620.

KOZLOWSKI, R.M.; MUZYCZEK, M. Improving the flame retardancy of natural fibres. In: KOZLOWSKI, Ryszard M. (Org.). . Handb. Nat. fibres. Vol. 2 Process. Appl. Cambridge: Woodhead Publishing Limited Abington Hall, 2012. p. 516.

KREITSCHITZ, Agnieszka; KOVALEV, Alexander; GORB, Stanislav N. Slipping vs sticking: Water-dependent adhesive and frictional properties of Linum usitatissimum L. seed mucilaginous envelope and its biological significance. Acta Biomaterialia, v. 17, p. 152-159, 2015.

KUFFNER, H.; POPESCU, C. Wool Fibres. In: KOZLOWSKI, Ryszard (Org.). . Handb. Nat. fibres. Vol. 1 Types, Prop. factors Affect. Breed. Cultiv. Cambridge: Woodhead Publishing Limited Abington Hall, 2012. p. 620.

LE BRAS, M.; BOURBIGOT, S. Flame Retardants. In: TROITZSCH, Dr. Jurgen (Org.). . Plast. Flammabl. Handbook. Princ. Regul. Test. Approv. 3rd Ed. 3rd. ed. Cincinnati: [s.n.], 2004. p. 740.

LEISTNER, Marcus et al. Water-based chitosan/melamine polyphosphate multilayer nanocoating that extinguishes fire on polyester-cotton fabric. Carbohydrate Polymers, v. 130 , p. 227-232, 2015.

LI, Lishuai et al. Anomaly detection via a Gaussian Mixture Model for flight operation and safety monitoring. v. 64, p. 45-57, 2016.

LOPES, Guilherme Bretz; FREIRE, Estevão. Implicações da Política Nacional de Resíduos Sólidos para as práticas de gestão de resíduos no setor de confecção. Redige Revista de Design, Inovação e Gestão Estratégica, 2013.

LOPES, Luis Felipe Dias et al. Estatística Geral. [S.1.]: Editora UFSM, 2005.

LORD, Peter R. Handbook of yarn production: Technology, science and economics. [S.1.]: Woodhead Publishing Limited Abington Hall, 2003.

MADRZYKOWSKI, Daniel; STROUP, David W. Flammability Hazard of Materials. Fire Protection Handbook, v. 11, n. 2, p. 2/31-48, 2008.

MAGALHÃES, Marcos Nascimento; LIMA, Antônio Carlos Pedroso de. Noções de Probabilidade e Estatística. São Paulo: Editora da Universidade de São Paulo EDUSP, 2015.

MALAGUTTI, Antônio Osller. Evolução da Aviação Civil, no Brasil. . Brasília: [s.n.], 2001.

MALUF, Eraldo; KOLBE, Wolfgang. Dados técnicos para a indústria têxtil. 2ed. ed. São Paulo: IPT - Instituto de Pesquisas Tecnológicas do Estado de São Paulo : ABIT Associação Brasileira da Indústria Têxtil e de Confecção, 2003.

MANSOOR, Shahid; PATERSON, Andrew H. Genomes for jeans : cotton genomics for 
engineering superior fiber. Trends in Biotechnology, v. 30, n. 10, p. 521-527, 2012.

MAO, N. High performance textile for protective clothing. In: LAWRENCE, Carl A. (Org.). . High Perform. Text. Their Appl. Cambridge: Woodhead Publishing Limited Abington Hall, 2014. p. 437.

MARCHENKOV, Anatoly et al. Cultivation of Flax. In: MUIR, Alister D.;

WESTCOTT, Neil D. (Org.). . Flax genus Linum. New York: Taylor and Francis Ltd., 2003. p. 296.

MARTIN, Nicolas et al. Influence of the degree of retting of flax fibers on the tensile properties of single fibers and short fiber/polypropylene composites. Industrial Crops and Products, v. 49, p. 755-767, 2013.

MCDONALDS, Fiona. Textile : A History. South Yorkshire: Pen \& Sword Books Limited, 2011.

MINITAB INC. Minitab User's Guide 2. [S.1: s.n.], 2000.

MOITA NETO, J.M. Estatística Multivariada - Uma visão didática-pedagógica. Disponível em: <http://143.54.226.61/ viali/cursos/ceea/multi/textos/Moita_Neto.pdf>. Acesso em: 20 jul. 2012.

MONTGOMERY, Douglas C. Introduction to Statistical Quality Control. [S.l: s.n.], 2009.

MORTON, W.E.; HEARLE, J.W.S. Equilibrium absorption of water. Phys. Prop.

Text. fibres. Cambridge: Woodhead Publishing Limited Abington Hall, 2009a. p. 765.

Fiber Density. Phys. Prop. Text. fibres. 4. ed. Cambridge: Woodhead Publishing Limited Abington Hall, 2009b. p. 765.

MUSSIG, Jorg; SLOOTMAKER, Tanja. Types of Fibres. In: MUSSIG, Jorg (Org.). . Ind. Appl. Nat. Fibres Struct. Prop. Tech. Appl. West Sussex: John Wiley \& Son LTD, 2010. p. 677.

NAYAK, R.K.; PADHYE, R.; FERGUSSON, S. Identification of natural textile fibres. In: KOSLOWSKI, Ryszard (Org.). . Handb. Nat. fibres. Vol. 1 Types, Prop. factors Affect. Breed. Cultiv. Cambridge: Woodhead Publishing Limited Abington Hall, 2012. p. 620.

NERY, Maria Luiza Costa. Frequência e prevalência de diagnósticos psiquiátricos determinantes do afastamento de comissários de bordo da atividade aérea. . São Paulo: Universidade de São Paulo. , 2009

OLIVEIRA, Sandra Regina. Rota de colisão. A história, a crise e o fim da Varig. Rio de Janeiro: E-Papers Serviços Gráficos Ltda, 2011.

PERINI, Alvaro Belotto et al. Anuário Estatístico Operacional 2016. Brasília: INFRAERO Aeroportos, 2017.

POSSI JÚNIOR, Rogério; PASSOS, Renato Crucello; OLIVEIRA FILHO, Oswaldo. Um novo Modelo para submissão de ocorrências aeronáuticas. Revista Conexão SIPAER, p. 163-180, nov. 2010.

QUATAR, Quatar Airways Standards and Procedures Office. Cabin Crew Grooming \& Uniform Regulation. . [S.l: s.n.]. , 2007 
RIBOLDI, João et al. PRECISÃO E PODER DE TESTES DE HOMOCEDASTICIDADE PARAMÉTRICOS E NÃO-PARAMÉTRICOS AVALIADOS POR 1 Introdução.

REVISTA BRASILEIRA DE BIOMETRIA, v. 32, n. 3, p. 1-11, 2014.

ROCKETT, John A.; MILKE, James. Conduction of heat in solids. SFPE - Handb. Fire Prot. Eng. 3. ed. Quincy: National Fire Protection Association, 2002. p. 1604.

RODRIGUES, Adriano; PAULO, Edilson. Introdução à Análise Multivatiada. Análise Multivariada para cursos Adm. Ciências Contábeis e Econ. 1 ed. ed. São Paulo: Editora Atlas, 2011. p. 1-72.

RUBBO, Roberto. Uniforme: Moda, conceitos, história e tendências. Disponível em: <http://www.audaces.com/br/educacao/falando-de-educacao/2012/12/28/uniforme-modaconceito-historia-e-tendencias>. Acesso em: 8 jan. 2016.

SANTOS, L.C.B.; ALMEIDA, C.A.; FARIAS, J.L. Aviões: Sumário Estatístico - 2008 a 2017. Disponível em:

<http://sistema.cenipa.aer.mil.br/cenipa/paginas/arquivos/avioes_sumario_estatistico.pdf>. Acesso em: 23 jul. 2018.

SAVILE, B.P. Strength and Elongation tests. Phys. Test. Text. Reprinted ed. Cambridge: Woodhead Publishing Limited Abington Hall, 2002. p. 344.

SILVEIRA, S. Manual da Matérias Primas Têxteis. Covilhã - Portugal: CILAN - Centro de Formação Profissional para a Indústria de Lanifícios, 2011.

SINCLAIR, Rose. Understanding Textile Fibres and Their properties : What is a Textile F ibre? Text. Fash. Mater. Des. Technol. Cambridge: Woodhead Publishing Limited Abington Hall, 2015. p. 845.

SOUZA, Marcelo Botelho. Combate a incêndio, teoria do fogo, conceito de fogo, elementos que compõem o fogo, classe de incêndio. Disponível em:

<http://segurancadotrabalho01.blogspot.com.br/2012/04/combate-incendioteoria-dofogoconceito.html>. Acesso em: 5 abr. 2017.

SPEECE, Jane. EC74-492 Fabric Flammability and Clothing. 1974.

STEVENSON, Todd. A. Consumer product safety. Federal Register, v. 73, n. 2015-08-19, p. 15636-15661, 2008.

THERMO ELECTRO CO. Nicolet FT-IR User's Guide. Disponível em:

<https://instrumentalanalysis.community.uaf.edu/files/2013/01/FT-IR_manual.pdf>. Acesso em: 19 jul. 2018.

TIEN, C.L.; LEE, K.Y.; STRETTON, A.J. Radiation Heat Transfer. SFPE - Handb. Fire Prot. Eng. Quincy: National Fire Protection Association, 2002. p. 1604.

TRIDICO, S.R. Natutal animal textile fibres: structure, characteristics and identification. In: HOUCK, Max M. (Org.). . Identif. Text. Fibres. Cambridge: Woodhead Publishing Limited Abington Hall, 2009. p. 375.

TYLER, Tony. IATA Annual Review 2015. p. 62, 2015.

U.S. DEPARTMENT OF TRANSPORTATION; FEDERAL AVIATION

ADMINISTRATION. Advisory Circular AC-2517-A:2016. Disponível em:

$<$ https://www.faa.gov/documentLibrary/media/Advisory_Circular/AC_25-17A_CHG-

1.pdf>. Acesso em: 23 jul. 2018.

UNITED, United Inflight Service. Your image is the United brand : Flight Attendant 
Uniform Appearance Standards. Disponível em:

$<$ https://unitedafa.org/docs/uniforms/appearance_standards.pdf >. Acesso em: 25 mar. 2017.

VAISEY-GENSER, Marion; MORRIS, Diane H. History of the cultivation and uses of flaxseed. In: MUIR, Alister D.; WESTCOTT, Neil D. (Org.). . Flax genus Linum. New York: Taylor and Francis Ltd., 2003. p. 296.

VANTOCH, Victoria. The Jet Sex: Airline Stewardesses and making of an American Icon. Philadelfia: University of Pensilvania, 2013.

VIRACOPOS AEROPORTOS BRASIL. RMA - Resumo de Movimentação

Aeroportuária. Disponível em: <http://www.viracopos.com/institucional/estatisticas-epublicacoes/>. Acesso em: 23 jul. 2018.

WAKELYN, P.J. Environmentally friendly flame resistant textile. In: HORROCKS, A.Richard; PRICE, D. (Org.). . Adv. fire Retard. Mater. Cambridge: Woodhead Publishing Limited Abington Hall, 2008. p. 625.

WALTON, William D.; THOMAS, Philip H. Estimating Temperatures in Compartments Fires. SFPE - Handb. Fire Prot. Eng. Quincy: National Fire Protection Association, 2002. p. 3-171.

WANG, Z. Halogen-free flame retardant. In: HORROCKS, A.Richard; PRICE, D. (Org.). . Adv. fire Retard. Mater. Cambridge: Woodhead Publishing Limited Abington Hall, 2008. p. 616.

WEIL, Edward D.; LEVCHIK, Sergei V. Flame Retard. Plast. Text. Cincinnati: Hanser Publishers, 2009.

WERKEMA, Maria Cristina Catarino. Criando a Cultura Seis Sigma. Rio de Janeiro: Qualitymark, 2002.

WHITLEGG, Drew. Working The Skies : The fast-paced, disorienting world of the flight attendant. New York: New York University Press, 2007.

WILKE, Sabine; MAJUMDAR, Arnab; OCHIENG, Washington Y. Airport surface operations : A holistic framework for operations modeling and risk management. Safety Science, v. 63, p. 18-33, 2014.

WORLD WEATHER, Online. Guimaraes Weather online. Disponível em:

$<$ https://www.worldweatheronline.com/guimaraes-

weather/braga/pt.aspx?wwo_r=srch>.

YOUNIS, A A. Evaluation of the flammability and thermal properties of a new flame retardant coating applied on polyester fabric. Egyptian Journal of Petroleum, v. 25, n. 2, p. 161-169, 2016.

ZHANG, Xia et al. ScienceDirect Morphological, cytological and molecular analyses of a synthetic hexaploid derived from an interspecific hybrid between Gossypium hirsutum and Gossypium anomalum. CJ, v. 2, n. 5, p. 272-277, 2014.

ZONATTI, Welton Fernando. Estudo interdisciplinar entre reciclagem têxtil e o design: avaliação de compósito produzidos com fibras de algodão. $2013.178 \mathrm{f}$. Universidade de São Paulo, 2013. 


\section{APÊNDICE A - FICHA DE IDENTIFICAÇÃO DAS PEÇAS DE UNIFORMES DE AERONAUTAS}

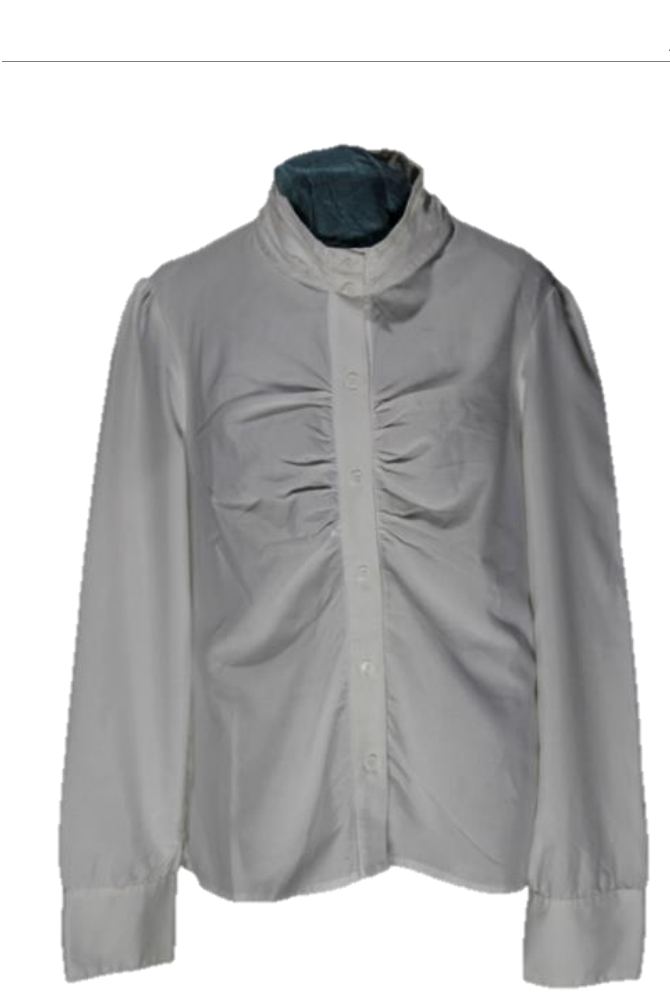

\section{Peça P1}

Descrição da peça

Camisa Feminina Branca com pregas no busto e mangas compridas

\begin{tabular}{r|lc} 
Origem & Linha Aérea A \\
Tamanho & 42 & \\
Material na Etiqueta & $100 \%$ Poliéster & \\
Estado & Usada & Urdume \\
Velocidade de Queima $(\mathrm{cm} / \mathrm{s})$ & $\mathbf{2 , 6 5} \pm 0,2651$ & $\mathbf{1 , 6 4} \pm 0,285$ \\
de trama e urdume $($ fios $/ \mathrm{cm})$ & 27 & 29 \\
Densidade Linear $($ tex $)$ & $\mathbf{1 6 , 8 2} \pm 0,29$ & $\mathbf{1 8 , 1 6} \pm 0,24$ \\
Torção (torções $/ \mathrm{m})$ & - & $\mathbf{8 9 1 , 2 5} \pm 25,33$ \\
Diâmetro do fio $(\mathrm{mm})$ & 0,155 & 0,163 \\
Gramatura $\left(\mathrm{g} / \mathrm{m}^{2}\right)$ & $\mathbf{1 0 9 , 5 2 \pm 0 , 7 5}$ & \\
Espessura $(\mathrm{mm})$ & $\mathbf{0 , 2 6 0} \pm 0,007$ & \\
Fator de Cobertura & 0,69 & \\
Ligamento & Sarja $2 \times 2$ &
\end{tabular}




\section{Peça P2}

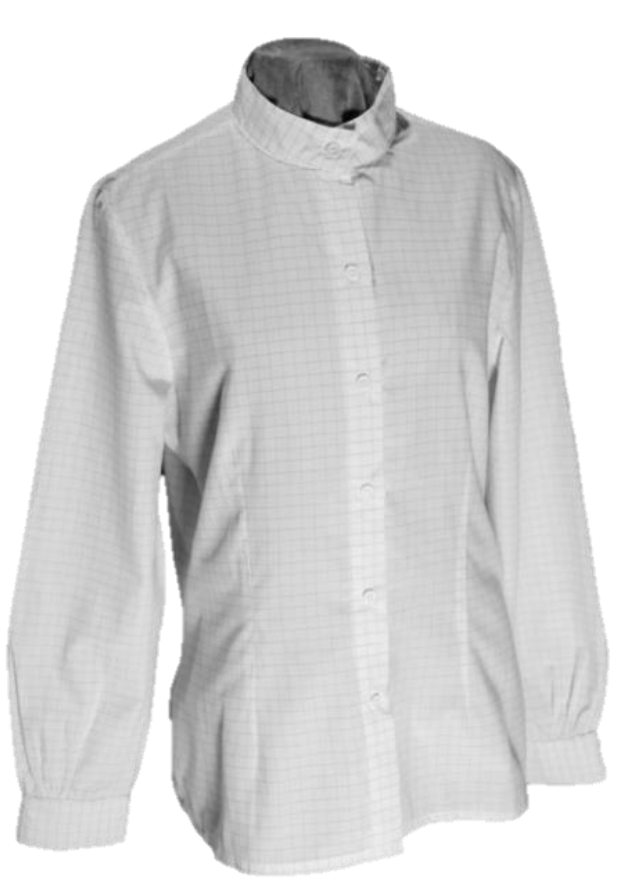

Descrição da peça

\begin{tabular}{|c|c|c|}
\hline & mangas compridas & \\
\hline Origem & Linha Aérea A & \\
\hline Tamanho & 42 & \\
\hline Material na Etiqueta & 100\% Poliéster & \\
\hline Estado & Nova & \\
\hline & Trama & Urdume \\
\hline Velocidade de queima $(\mathrm{cm} / \mathrm{s})$ & $\mathbf{2 , 8 9 1} \pm 0,514$ & $\mathbf{3 , 8 2 7} \pm 0,462$ \\
\hline de trama e urdume (fios/cm) & 34 & 40 \\
\hline Densidade Linear (tex) & $13,67 \pm 0,54$ & $\mathbf{9 , 2 7} \pm 0,43$ \\
\hline Torção $($ torções/m) & - & - \\
\hline Diâmetro do fio (mm) & 0,139 & 0,115 \\
\hline Gramatura $\left(\mathrm{g} / \mathrm{m}^{2}\right)$ & $\mathbf{9 5 , 0 9} \pm 2,93$ & \\
\hline Espessura $(\mathrm{mm})$ & $\mathbf{0 , 2 1 0} \pm 0,007$ & \\
\hline Fator de Cobertura & 0,72 & \\
\hline Ligamento & Tela & \\
\hline
\end{tabular}




\section{Peça P3}

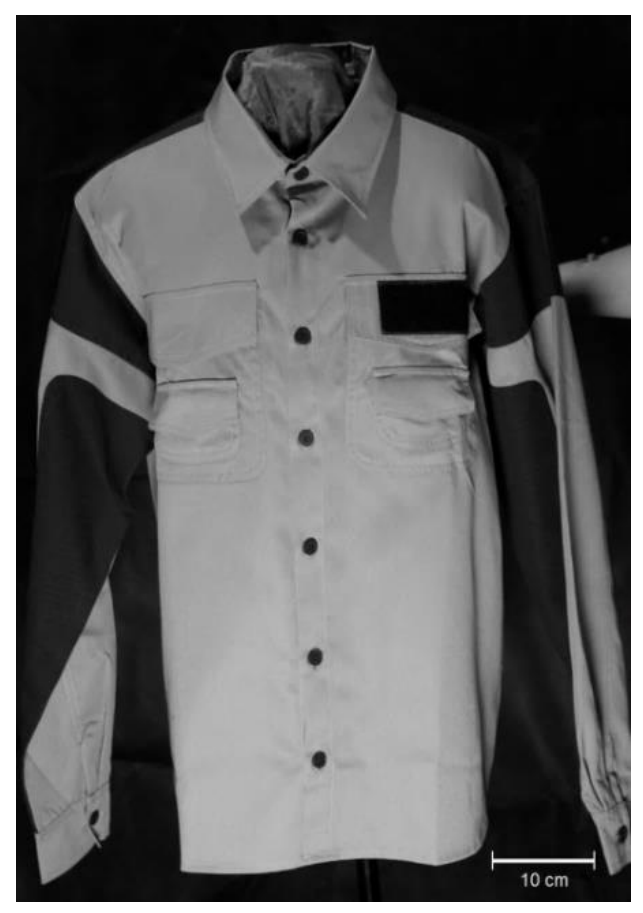

Descrição da peça

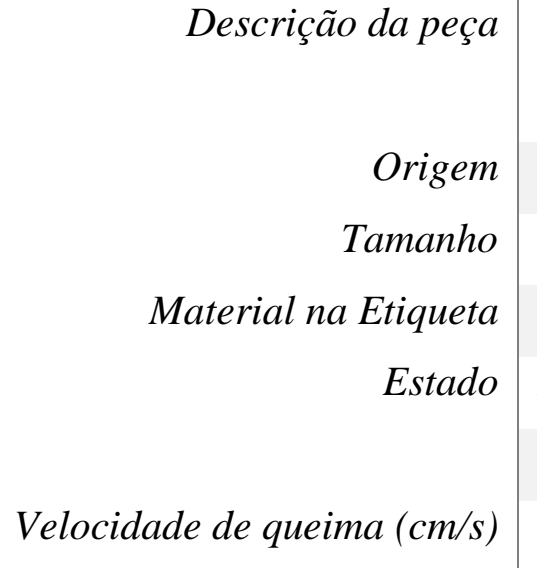

Fios de trama e urdume (fios/cm)

Densidade Linear (tex)

Torção (torções $/ m$ )

Diâmetro do fio ( $\mathrm{mm})$

Gramatura $\left(\mathrm{g} / \mathrm{m}^{2}\right)$

Espessura (mm)

Fator de Cobertura

Ligamento
Camisa masculina de serviço mangas compridas

\section{Linha Aérea A}

$\mathrm{G}$

67\% Poliéster/33\% Algodão

Nova

$$
\text { Trama Urdume }
$$

$$
\mathbf{1 , 3 4 0} \pm 0,116 \quad \mathbf{1 , 4 1 0} \pm 0,070
$$

24

39

$\mathbf{3 0 , 8 5} \pm 1,50$

$\mathbf{2 5 , 4 3} \pm 1,35$
0,206
0,187

$195,51 \pm 1,03$

$\mathbf{0 , 3 9 0} \pm 0,012$

0,86

Sarja 2 x 1 


\section{Peça P4}

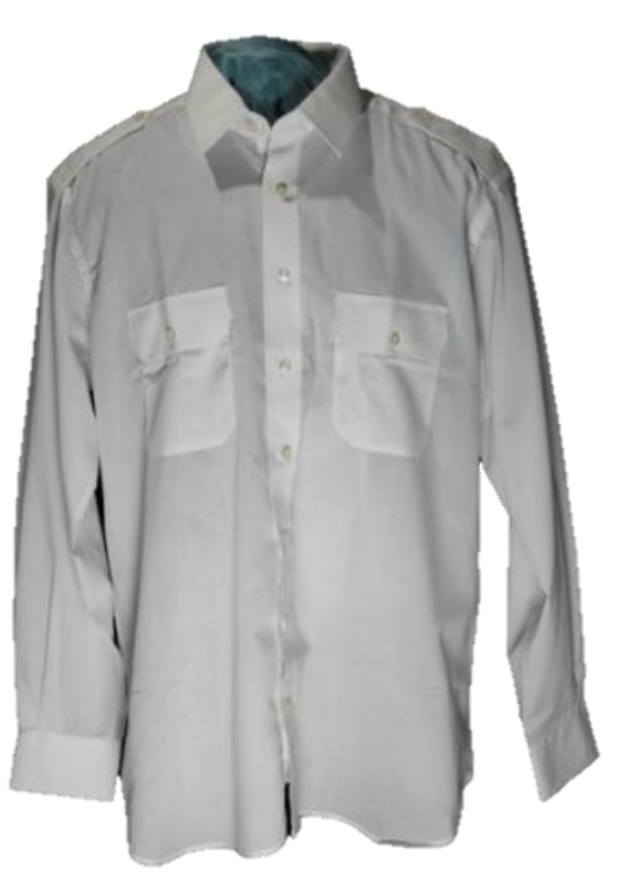

Descrição da peça

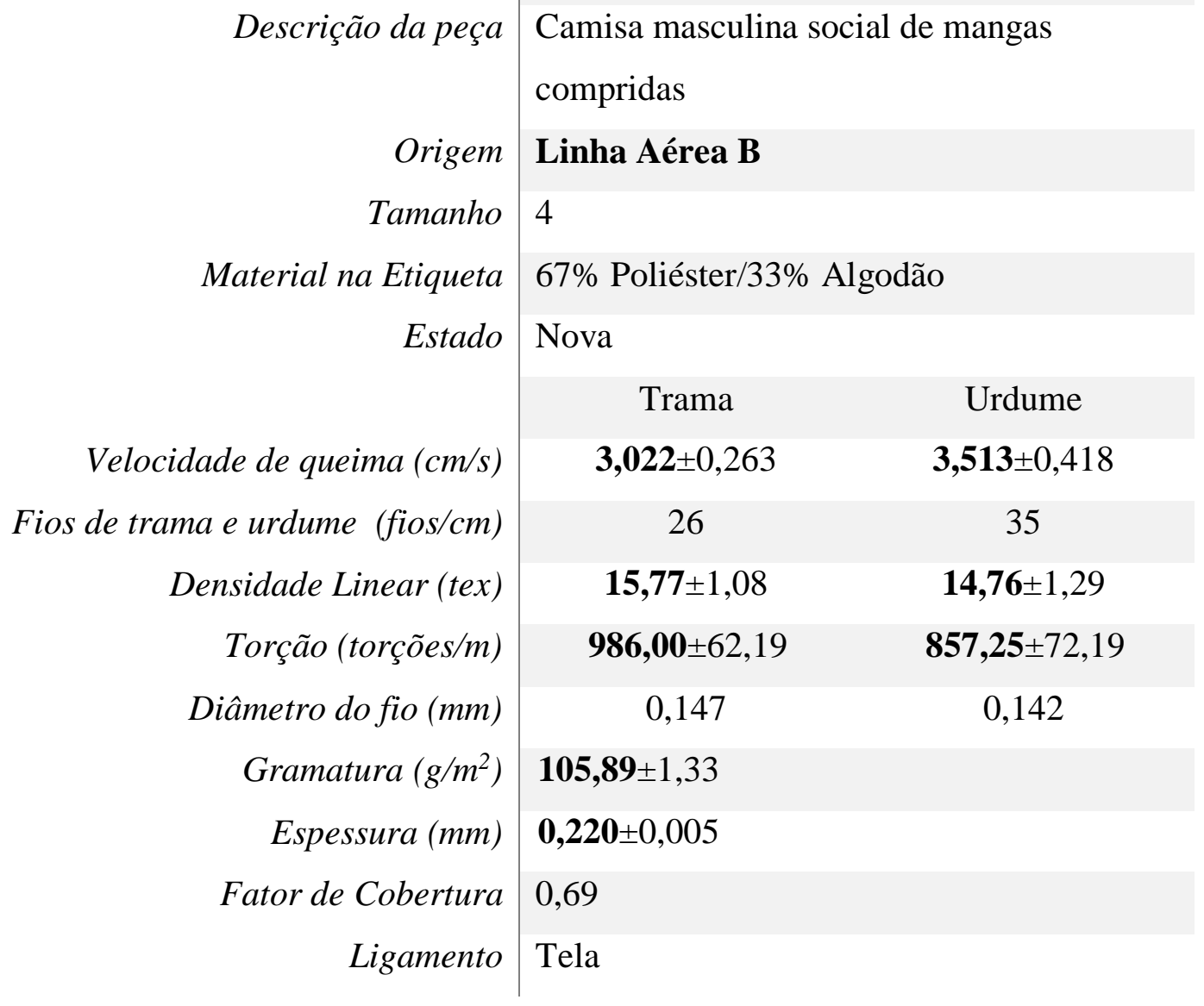




\section{Peça P5}

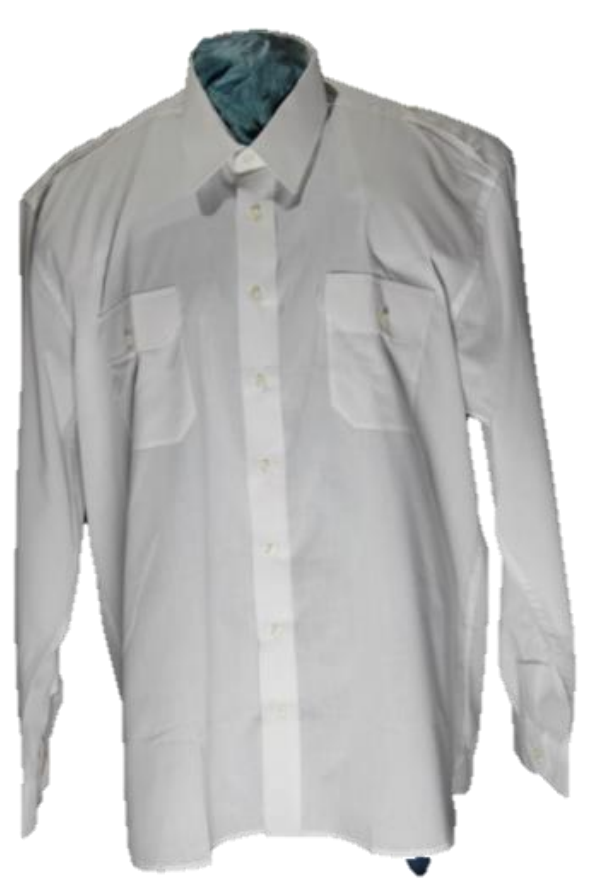

Descrição da peça

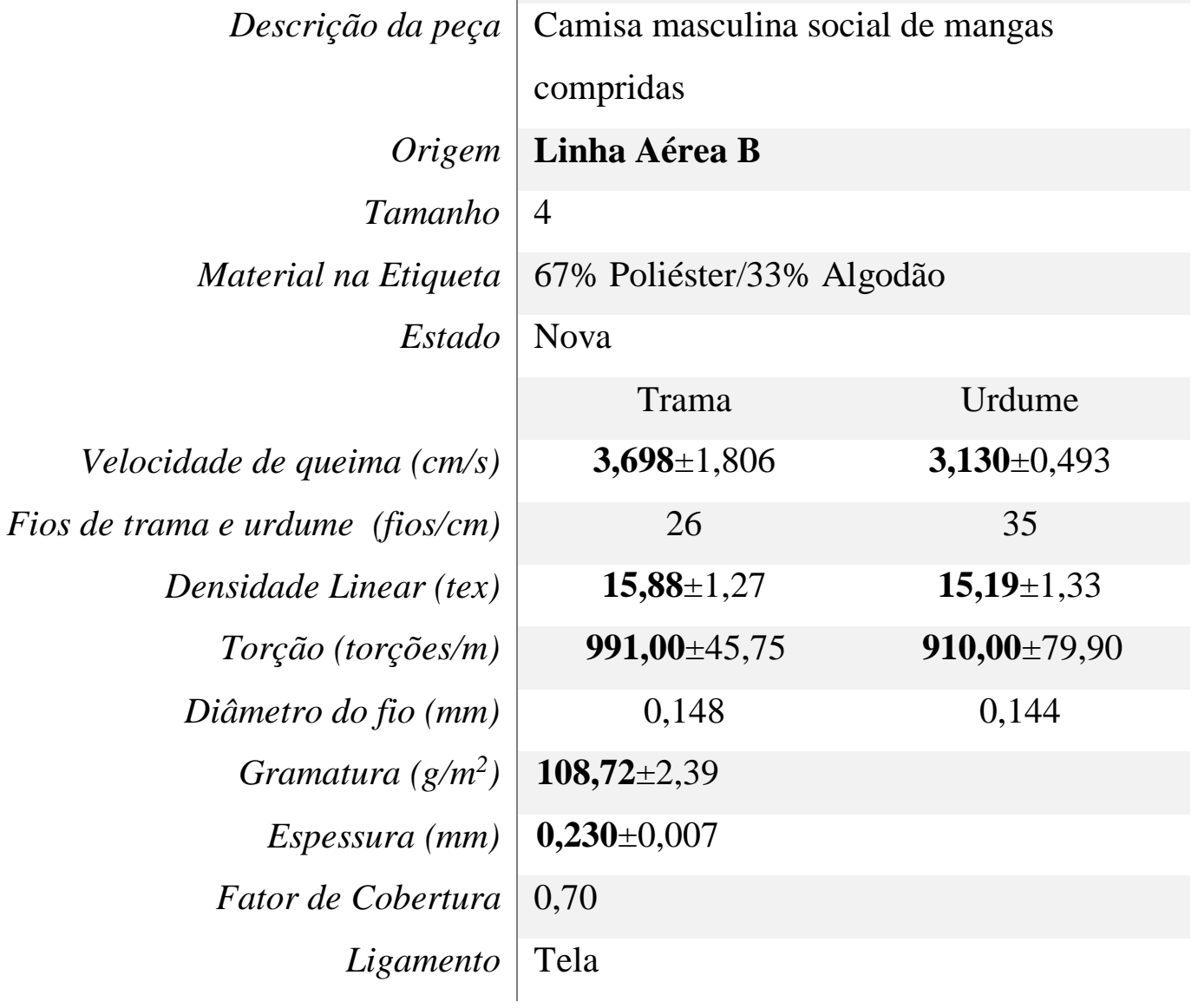




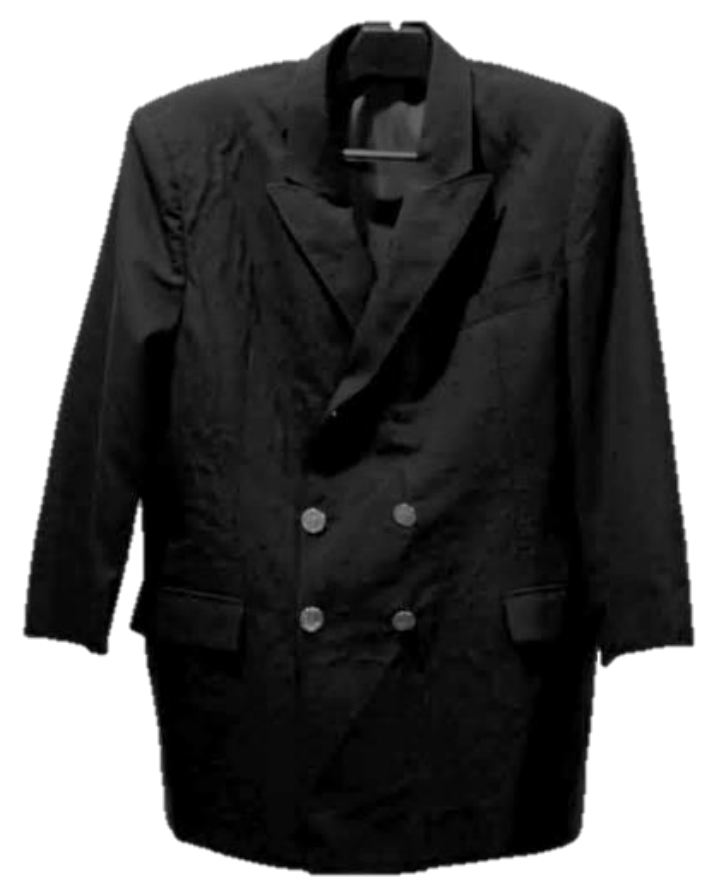

Descrição da peça

Origem

Tamanho

Material na Etiqueta

Estado

Velocidade de queima $(\mathrm{cm} / \mathrm{s})$

Fios de trama e urdume (fios/cm)

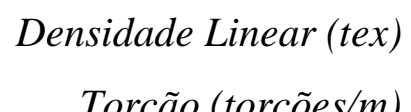

Torção (torções $/ m)$

Diâmetro do fio $(\mathrm{mm})$

Gramatura $\left(\mathrm{g} / \mathrm{m}^{2}\right)$

Espessura (mm)

Fator de Cobertura

Ligamento
Paletó masculino de 4 botões

\section{Linha Aérea B}

54

$55 \%$ poliéster / $45 \%$ lã

Usado

$$
\text { Trama }
$$

Urdume

$$
\text { 0,972 } \pm 0,114
$$

$\mathbf{0 , 9 7 9} \pm 0,130$

22

22

36,72 $\pm 3,43$

$\mathbf{3 5 , 8 8} \pm 2,31$

$\mathbf{5 4 9 , 0 0 \pm 4 7 , 4 8}$

$\mathbf{5 5 6 , 0 0} \pm 34,78$

0,240

0,237

$179,96 \pm 1,27$

$\mathbf{0 , 3 6 0} \pm 0,011$

0,77

Tela 


\section{Peça P7}

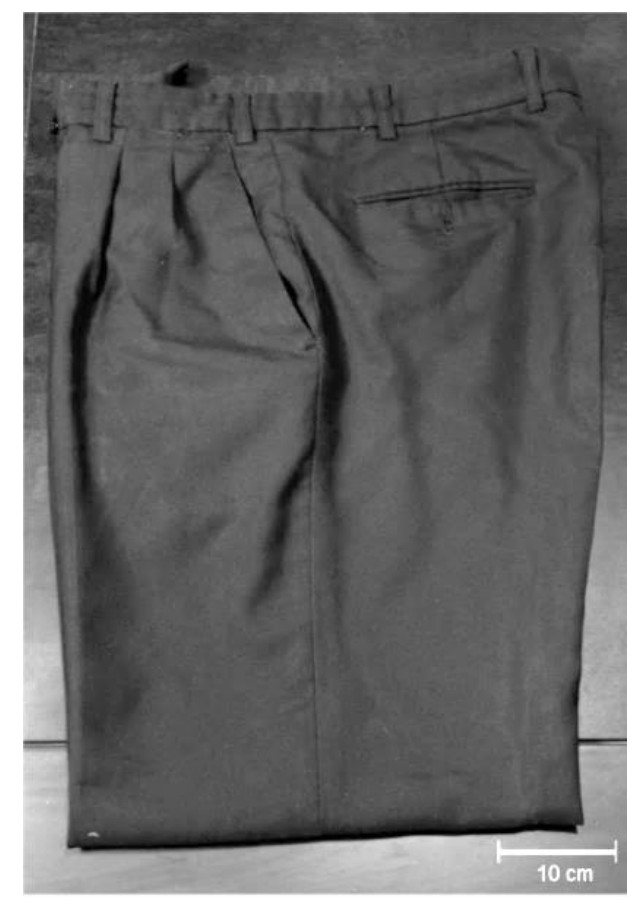

Descrição da peça

Origem

Tamanho

Material na Etiqueta

Estado

Velocidade de queima $(\mathrm{cm} / \mathrm{s})$

Fios de trama e urdume (fios/cm)

$$
\begin{array}{r}
\text { Densidade Linear (tex) } \\
\text { Torção (torções } / m \text { ) }
\end{array}
$$

Diâmetro do fio $(\mathrm{mm})$

Gramatura $\left(\mathrm{g} / \mathrm{m}^{2}\right)$

Espessura (mm)

Fator de Cobertura

Ligamento
Pea

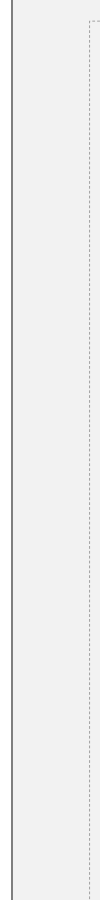

Calça comprida masculina

\section{Linha Aérea B}

46

$50 \%$ lã / 50\% poliéster

Usada

Trama

Urdume
$\mathbf{0 , 7 4 2} \pm 0,140$
0,934 $\pm 0,080$

20

22

$\mathbf{3 5 , 3 1} \pm 2,25$

$\mathbf{5 9 8 , 0 0 \pm 4 5 , 3 4}$

$\mathbf{5 6 2 , 0 0} \pm 58,55$

0,219

0,218

$\mathbf{2 2 5 , 1 2 \pm 5 , 0 2}$

$\mathbf{0 , 4 5 0} \pm 0,020$

0,71

tela 


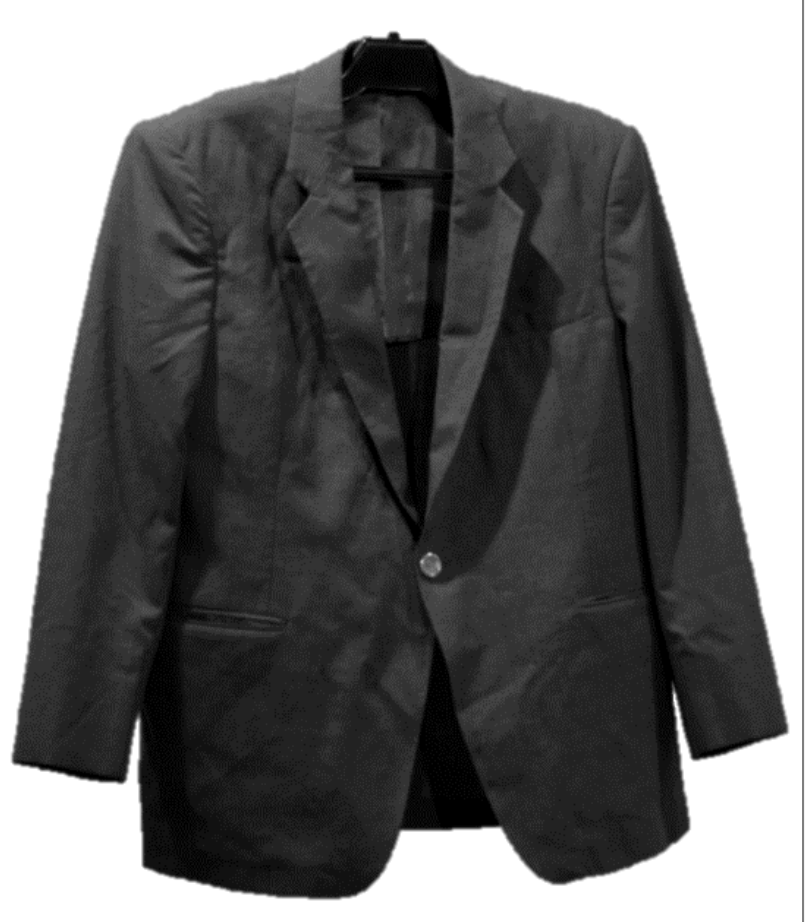

Descrição da peça Origem

Tamanho

Material na Etiqueta

Estado

Velocidade de queima $(\mathrm{cm} / \mathrm{s})$

Fios de trama e urdume (fios/cm)

$$
\begin{array}{r}
\text { Densidade Linear (tex) } \\
\text { Torção (torções } / m \text { ) }
\end{array}
$$

Diâmetro do fio $(\mathrm{mm})$

Gramatura $\left(\mathrm{g} / \mathrm{m}^{2}\right)$

Espessura (mm)

Fator de Cobertura

Ligamento
Paletó masculino de 1 botão

\section{Linha Aérea B}

54

$55 \%$ poliéster/ $45 \%$ lã

Usada

$\begin{array}{cc}\text { Trama } & \text { Urdume } \\ \mathbf{0 , 9 9 4} \pm 0,121 & \mathbf{1 , 0 3 0} \pm 0,10\end{array}$

22

22

$\mathbf{3 5 , 6 8} \pm 1,99$

$\mathbf{3 6 , 0 3} \pm 3,38$

$\mathbf{5 0 7 , 5 0} \pm 40,91 \quad \mathbf{5 4 8 , 0 0} \pm 40,50$

$0,228 \quad 0,227$

$168,04 \pm 1,98$

$\mathbf{0 , 3 5 0} \pm 0,007$

0,75

Tela 
APÊNDICE B - CARACTERÍSTICAS DO MATERIAL TÊXTIL DOS UNIFORMES DOS AERONAUTAS (P1 A P8) E TECIDOS PROFISSIONAIS (T1 A T3)

\begin{tabular}{|c|c|c|c|c|c|c|c|c|c|c|c|c|}
\hline$P e c ̧ a$ & $T R$ & $U R$ & $\begin{array}{l}\text { Fator de } \\
\text { Cobertura }\end{array}$ & Ligamento & Composição & Direção & $\begin{array}{c}\text { Torção } \\
\text { (torções } / m)\end{array}$ & $\begin{array}{l}\text { Gramatura } \\
(\mathrm{g} / \mathrm{m} 2)\end{array}$ & $\begin{array}{l}\text { Espessura } \\
(\mathrm{mm})\end{array}$ & $\begin{array}{c}\text { Diâmetro } \\
\text { do Fio } \\
(\mathrm{mm})\end{array}$ & $\begin{array}{l}\text { Densidade } \\
\text { Linear } \\
\text { (tex) }\end{array}$ & $\begin{array}{c}\text { Velocidade } \\
\text { de Queima } \\
(\mathrm{cm} / \mathrm{s})\end{array}$ \\
\hline$P 1$ & 27 & 29 & 0,67 & Sarja & PES & Trama & 0,00 & 109,17 & 0,26 & 0,1503 & 17,51 & 2,66 \\
\hline$P 1$ & 27 & 29 & 0,67 & Sarja & PES & Urdume & 892,50 & 109,17 & 0,26 & 0,1560 & 18,89 & 1,68 \\
\hline$P 1$ & 27 & 29 & 0,67 & Sarja & PES & Trama & 0,00 & 109,97 & 0,26 & 0,1462 & 16,57 & 2,45 \\
\hline$P 1$ & 27 & 29 & 0,67 & Sarja & PES & Urdume & 872,50 & 109,97 & 0,26 & 0,1582 & 19,41 & 2,01 \\
\hline$P 1$ & 27 & 29 & 0,67 & Sarja & PES & Trama & 0,00 & 107,90 & 0,25 & 0,1473 & 16,82 & 2,93 \\
\hline$P 1$ & 27 & 29 & 0,67 & Sarja & PES & Urdume & 885,00 & 107,90 & 0,25 & 0,1560 & 18,89 & 2,10 \\
\hline$P 1$ & 27 & 29 & 0,67 & Sarja & PES & Trama & 0,00 & 109,63 & 0,26 & 0,1481 & 17,01 & 2,71 \\
\hline$P 1$ & 27 & 29 & 0,67 & Sarja & PES & Urdume & 882,50 & 109,63 & 0,26 & 0,1544 & 18,48 & 1,20 \\
\hline$P 1$ & 27 & 29 & 0,67 & Sarja & PES & Trama & 0,00 & 110,22 & 0,26 & 0,1456 & 16,45 & 2,39 \\
\hline$P 1$ & 27 & 29 & 0,67 & Sarja & PES & Urdume & 937,50 & 110,22 & 0,26 & 0,1562 & 18,92 & 1,62 \\
\hline$P 1$ & 27 & 29 & 0,67 & Sarja & PES & Trama & 0,00 & 110,37 & 0,27 & 0,1473 & 16,82 & 2,74 \\
\hline$P 1$ & 27 & 29 & 0,67 & Sarja & PES & Urdume & 920,00 & 110,37 & 0,27 & 0,1547 & 18,55 & 1,68 \\
\hline$P 1$ & 27 & 29 & 0,67 & Sarja & PES & Trama & 0,00 & 109,61 & 0,26 & 0,1480 & 16,98 & 2,19 \\
\hline$P 1$ & 27 & 29 & 0,67 & Sarja & PES & Urdume & 917,50 & 109,61 & 0,26 & 0,1530 & 18,15 & 1,37 \\
\hline$P 1$ & 27 & 29 & 0,67 & Sarja & PES & Trama & 0,00 & 108,96 & 0,25 & 0,1464 & 16,64 & 2,63 \\
\hline$P 1$ & 27 & 29 & 0,67 & Sarja & PES & Urdume & 875,00 & 108,96 & 0,25 & 0,1541 & 18,42 & 1,85 \\
\hline$P 1$ & 27 & 29 & 0,66 & Sarja & PES & Trama & 0,00 & 110,20 & 0,25 & 0,1464 & 16,64 & 3,12 \\
\hline$P 1$ & 27 & 29 & 0,66 & Sarja & PES & Urdume & 867,50 & 110,20 & 0,25 & 0,1527 & 18,08 & 1,54 \\
\hline$P 1$ & 27 & 29 & 0,66 & Sarja & PES & Trama & 0,00 & 109,15 & 0,27 & 0,1470 & 16,76 & 2,69 \\
\hline$P 1$ & 27 & 29 & 0,66 & Sarja & PES & Urdume & 862,50 & 109,15 & 0,27 & 0,1514 & 17,78 & 1,40 \\
\hline
\end{tabular}




\begin{tabular}{|c|c|c|c|c|c|c|c|c|c|c|c|c|}
\hline$P 2$ & 34 & 40 & 0,70 & Tela & PES & Trama & 0,00 & 91,58 & 0,21 & 0,1345 & 14,02 & 2,47 \\
\hline$P 2$ & 34 & 40 & 0,70 & Tela & PES & Urdume & 0,00 & 91,58 & 0,21 & 0,1130 & 9,91 & 3,73 \\
\hline$P 2$ & 34 & 40 & 0,70 & Tela & PES & Trama & 0,00 & 92,51 & 0,20 & 0,1378 & 14,72 & 2,75 \\
\hline$P 2$ & 34 & 40 & 0,70 & Tela & PES & Urdume & 0,00 & 92,51 & 0,20 & 0,1078 & 9,01 & 3,16 \\
\hline$P 2$ & 34 & 40 & 0,70 & Tela & PES & Trama & 0,00 & 94,46 & 0,20 & 0,1311 & 13,33 & 2,50 \\
\hline$P 2$ & 34 & 40 & 0,70 & Tela & PES & Urdume & 0,00 & 94,46 & 0,20 & 0,1132 & 9,94 & 3,74 \\
\hline$P 2$ & 34 & 40 & 0,70 & Tela & PES & Trama & 0,00 & 100,09 & 0,21 & 0,1324 & 13,60 & 4,13 \\
\hline$P 2$ & 34 & 40 & 0,70 & Tela & PES & Urdume & 0,00 & 100,09 & 0,21 & 0,1118 & 9,69 & 3,90 \\
\hline$P 2$ & 34 & 40 & 0,69 & Tela & PES & Trama & 0,00 & 94,94 & 0,20 & 0,1343 & 13,98 & 3,13 \\
\hline$P 2$ & 34 & 40 & 0,69 & Tela & PES & Urdume & 0,00 & 94,94 & 0,20 & 0,1096 & 9,32 & 3,79 \\
\hline$P 2$ & 34 & 40 & 0,69 & Tela & PES & Trama & 0,00 & 98,32 & 0,20 & 0,1355 & 14,24 & 2,99 \\
\hline$P 2$ & 34 & 40 & 0,69 & Tela & PES & Urdume & 0,00 & 98,32 & 0,20 & 0,1076 & 8,98 & 4,82 \\
\hline$P 2$ & 34 & 40 & 0,69 & Tela & PES & Trama & 0,00 & 98,73 & 0,22 & 0,1338 & 13,90 & 2,58 \\
\hline$P 2$ & 34 & 40 & 0,69 & Tela & PES & Urdume & 0,00 & 98,73 & 0,22 & 0,1079 & 9,03 & 3,70 \\
\hline$P 2$ & 34 & 40 & 0,69 & Tela & PES & Trama & 0,00 & 92,66 & 0,20 & 0,1311 & 13,33 & 3,13 \\
\hline$P 2$ & 34 & 40 & 0,69 & Tela & PES & Urdume & 0,00 & 92,66 & 0,20 & 0,1094 & 9,29 & 3,97 \\
\hline$P 2$ & 34 & 40 & 0,69 & Tela & PES & Trama & 0,00 & 93,70 & 0,21 & 0,1298 & 13,07 & 2,36 \\
\hline$P 2$ & 34 & 40 & 0,69 & Tela & PES & Urdume & 0,00 & 93,70 & 0,21 & 0,1096 & 9,32 & 3,28 \\
\hline$P 2$ & 34 & 40 & 0,68 & Tela & PES & Trama & 0,00 & 93,89 & 0,20 & 0,1298 & 13,07 & 2,87 \\
\hline$P 2$ & 34 & 40 & 0,68 & Tela & PES & Urdume & 0,00 & 93,89 & 0,20 & 0,1076 & 8,98 & 4,18 \\
\hline$P 3$ & 24 & 39 & 0,86 & Sarja & $\mathrm{PES} / \mathrm{CO}$ & Trama & 0,00 & 195,66 & 0,38 & 0,2047 & 32,49 & 1,45 \\
\hline$P 3$ & 24 & 39 & 0,86 & Sarja & $\mathrm{PES} / \mathrm{CO}$ & Urdume & 0,00 & 195,66 & 0,38 & 0,1880 & 27,41 & 1,28 \\
\hline$P 3$ & 24 & 39 & 0,86 & Sarja & PES/CO & Trama & 0,00 & 197,02 & 0,37 & 0,2037 & 32,18 & 1,44 \\
\hline$P 3$ & 24 & 39 & 0,86 & Sarja & $\mathrm{PES} / \mathrm{CO}$ & Urdume & 0,00 & 197,02 & 0,37 & 0,1869 & 27,10 & 1,42 \\
\hline$P 3$ & 24 & 39 & 0,85 & Sarja & PES/CO & Trama & 0,00 & 195,94 & 0,38 & 0,2003 & 31,11 & 1,21 \\
\hline$P 3$ & 24 & 39 & 0,85 & Sarja & $\mathrm{PES} / \mathrm{CO}$ & Urdume & 0,00 & 195,94 & 0,38 & 0,1848 & 26,48 & 1,50 \\
\hline$P 3$ & 24 & 39 & 0,85 & Sarja & $\mathrm{PES} / \mathrm{CO}$ & Trama & 0,00 & 195,32 & 0,37 & 0,2060 & 32,92 & 1,16 \\
\hline$P 3$ & 24 & 39 & 0,85 & Sarja & $\mathrm{PES} / \mathrm{CO}$ & Urdume & 0,00 & 195,32 & 0,37 & 0,1804 & 25,23 & 1,38 \\
\hline
\end{tabular}




\begin{tabular}{|c|c|c|c|c|c|c|c|c|c|c|c|}
\hline P3 & $24 \quad 39$ & 0,85 & Sarja & PES/CO & Trama & 0,00 & 194,20 & 0,38 & 0,1969 & 30,06 & 1,28 \\
\hline P3 & 39 & 0,85 & Sarja & $\mathrm{PES} / \mathrm{CO}$ & Urdume & 0,00 & 194,20 & 0,38 & 0,1826 & 25,86 & 1,45 \\
\hline$P 3$ & 39 & 0,85 & Sarja & $\mathrm{PES} / \mathrm{CO}$ & Trama & 0,00 & 195,73 & 0,39 & 0,1940 & 29,19 & 1,53 \\
\hline$P 3$ & 39 & 0,85 & Sarja & $\mathrm{PES} / \mathrm{CO}$ & Urdume & 0,00 & 195,73 & 0,39 & 0,1831 & 26,01 & 1,39 \\
\hline$P 3$ & 39 & 0,84 & Sarja & $\mathrm{PES} / \mathrm{CO}$ & Trama & 0,00 & 193,53 & 0,39 & 0,1998 & 30,96 & 1,32 \\
\hline P3 & 39 & 0,84 & Sarja & $\mathrm{PES} / \mathrm{CO}$ & Urdume & 0,00 & 193,53 & 0,39 & 0,1792 & 24,92 & 1,47 \\
\hline P3 & 39 & 0,84 & Sarja & $\mathrm{PES} / \mathrm{CO}$ & Trama & 0,00 & 196,08 & 0,41 & 0,1927 & 28,80 & 1,42 \\
\hline$P 3$ & 39 & 0,84 & Sarja & $\mathrm{PES} / \mathrm{CO}$ & Urdume & 0,00 & 196,08 & 0,41 & 0,1795 & 25,00 & 1,41 \\
\hline$P 3$ & 39 & 0,84 & Sarja & $\mathrm{PES} / \mathrm{CO}$ & Trama & 0,00 & 196,47 & 0,39 & 0,2047 & 32,49 & 1,33 \\
\hline P3 & 39 & 0,84 & Sarja & $\mathrm{PES} / \mathrm{CO}$ & Urdume & 0,00 & 196,47 & 0,39 & 0,1744 & 23,60 & 1,48 \\
\hline P3 & 39 & 0,83 & Sarja & $\mathrm{PES} / \mathrm{CO}$ & Trama & 0,00 & 195,10 & 0,39 & 0,1955 & 29,65 & 1,26 \\
\hline P3 & 39 & 0,83 & Sarja & $\mathrm{PES} / \mathrm{CO}$ & Urdume & 0,00 & 195,10 & 0,39 & 0,1721 & 22,98 & 1,32 \\
\hline P4 & 35 & 0,69 & Tela & $\mathrm{PES} / \mathrm{CO}$ & Trama & 1045,00 & 105,42 & 0,22 & 0,1509 & 17,66 & 2,92 \\
\hline$P 4$ & 35 & 0,69 & Tela & $\mathrm{PES} / \mathrm{CO}$ & Urdume & 722,50 & 105,42 & 0,22 & 0,1415 & 15,53 & 3,35 \\
\hline P4 & 35 & 0,69 & Tela & $\mathrm{PES} / \mathrm{CO}$ & Trama & 1012,50 & 103,94 & 0,22 & 0,1375 & 14,67 & 3,17 \\
\hline P4 & 35 & 0,69 & Tela & $\mathrm{PES} / \mathrm{CO}$ & Urdume & 922,50 & 103,94 & 0,22 & 0,1471 & 16,77 & 3,31 \\
\hline P4 & 35 & 0,69 & Tela & $\mathrm{PES} / \mathrm{CO}$ & Trama & 1005,00 & 104,14 & 0,23 & 0,1387 & 14,93 & 2,93 \\
\hline P4 & 35 & 0,69 & Tela & $\mathrm{PES} / \mathrm{CO}$ & Urdume & 860,00 & 104,14 & 0,23 & 0,1456 & 16,45 & 4,40 \\
\hline P4 & 35 & 0,69 & Tela & PES/CO & Trama & 995,00 & 105,82 & 0,23 & 0,1426 & 15,77 & 3,31 \\
\hline P4 & 35 & 0,69 & Tela & $\mathrm{PES} / \mathrm{CO}$ & Urdume & 817,50 & 105,82 & 0,23 & 0,1430 & 15,86 & 3,46 \\
\hline P4 & 35 & 0,67 & Tela & $\mathrm{PES} / \mathrm{CO}$ & Trama & 962,50 & 106,02 & 0,22 & 0,1355 & 14,24 & 3,38 \\
\hline$P 4$ & 35 & 0,67 & Tela & PES/CO & Urdume & 917,50 & 106,02 & 0,22 & 0,1403 & 15,26 & 3,58 \\
\hline$P 4$ & 35 & 0,67 & Tela & $\mathrm{PES} / \mathrm{CO}$ & Trama & 1030,00 & 107,41 & 0,22 & 0,1428 & 15,82 & 3,05 \\
\hline$P 4$ & 35 & 0,67 & Tela & $\mathrm{PES} / \mathrm{CO}$ & Urdume & 912,50 & 107,41 & 0,22 & 0,1351 & 14,15 & 2,95 \\
\hline$P 4$ & 35 & 0,67 & Tela & $\mathrm{PES} / \mathrm{CO}$ & Trama & 917,50 & 105,10 & 0,22 & 0,1494 & 17,31 & 3,07 \\
\hline$P 4$ & 35 & 0,67 & Tela & $\mathrm{PES} / \mathrm{CO}$ & Urdume & 825,00 & 105,10 & 0,22 & 0,1308 & 13,27 & 3,34 \\
\hline$P 4$ & 35 & 0,67 & Tela & PES/CO & Trama & 1065,00 & 108,11 & 0,22 & 0,1395 & 15,09 & 2,62 \\
\hline$P 4$ & 35 & 0,67 & Tela & $\mathrm{PES} / \mathrm{CO}$ & Urdume & 965,00 & 108,11 & 0,22 & 0,1370 & 14,56 & 3,10 \\
\hline
\end{tabular}




\begin{tabular}{|c|c|c|c|c|c|c|c|c|c|c|c|c|}
\hline P4 & 26 & 35 & 0,67 & Tela & $\mathrm{PES} / \mathrm{CO}$ & Trama & 857,50 & 106,18 & 0,23 & 0,1464 & 16,62 & 3,19 \\
\hline P4 & 26 & 35 & 0,67 & Tela & $\mathrm{PES} / \mathrm{CO}$ & Urdume & 815,00 & 106,18 & 0,23 & 0,1322 & 13,55 & 3,79 \\
\hline P4 & 26 & 35 & 0,66 & Tela & $\mathrm{PES} / \mathrm{CO}$ & Trama & 970,00 & 106,78 & 0,22 & 0,1408 & 15,38 & 2,59 \\
\hline P4 & 26 & 35 & 0,66 & Tela & $\mathrm{PES} / \mathrm{CO}$ & Urdume & 815,00 & 106,78 & 0,22 & 0,1333 & 13,78 & 3,86 \\
\hline P5 & 26 & 35 & 0,71 & Tela & PES/CO & Trama & 1000,00 & 106,83 & 0,22 & 0,1479 & 16,96 & 3,25 \\
\hline P5 & 26 & 35 & 0,71 & Tela & $\mathrm{PES} / \mathrm{CO}$ & Urdume & 985,00 & 106,83 & 0,22 & 0,1519 & 17,89 & 2,34 \\
\hline P5 & 26 & 35 & 0,70 & Tela & PES/CO & Trama & 1027,50 & 109,94 & 0,24 & 0,1477 & 16,91 & 3,16 \\
\hline P5 & 26 & 35 & 0,70 & Tela & $\mathrm{PES} / \mathrm{CO}$ & Urdume & 962,50 & 109,94 & 0,24 & 0,1461 & 16,56 & 3,47 \\
\hline P5 & 26 & 35 & 0,69 & Tela & $\mathrm{PES} / \mathrm{CO}$ & Trama & 922,50 & 112,82 & 0,23 & 0,1509 & 17,66 & 3,44 \\
\hline P5 & 26 & 35 & 0,69 & Tela & $\mathrm{PES} / \mathrm{CO}$ & Urdume & 782,50 & 112,82 & 0,23 & 0,1418 & 15,61 & 3,06 \\
\hline P5 & 26 & 35 & 0,69 & Tela & $\mathrm{PES} / \mathrm{CO}$ & Trama & 945,00 & 111,59 & 0,24 & 0,1457 & 16,47 & 3,66 \\
\hline P5 & 26 & 35 & 0,69 & Tela & $\mathrm{PES} / \mathrm{CO}$ & Urdume & 927,50 & 111,59 & 0,24 & 0,1421 & 15,65 & 2,51 \\
\hline P5 & 26 & 35 & 0,68 & Tela & PES/CO & Trama & 935,00 & 108,27 & 0,24 & 0,1487 & 17,16 & 3,26 \\
\hline P5 & 26 & 35 & 0,68 & Tela & $\mathrm{PES} / \mathrm{CO}$ & Urdume & 830,00 & 108,27 & 0,24 & 0,1374 & 14,65 & 3,18 \\
\hline P5 & 26 & 35 & 0,68 & Tela & PES/CO & Trama & 1000,00 & 106,33 & 0,23 & 0,1369 & 14,54 & 2,75 \\
\hline P5 & 26 & 35 & 0,68 & Tela & $\mathrm{PES} / \mathrm{CO}$ & Urdume & 860,00 & 106,33 & 0,23 & 0,1436 & 15,99 & 3,34 \\
\hline P5 & 26 & 35 & 0,66 & Tela & $\mathrm{PES} / \mathrm{CO}$ & Trama & 995,00 & 107,79 & 0,24 & 0,1355 & 14,24 & 4,77 \\
\hline P5 & 26 & 35 & 0,66 & Tela & PES/CO & Urdume & 1017,50 & 107,79 & 0,24 & 0,1376 & 14,70 & 3,44 \\
\hline P5 & 26 & 35 & 0,66 & Tela & $\mathrm{PES} / \mathrm{CO}$ & Trama & 1067,50 & 110,35 & 0,23 & 0,1355 & 14,24 & 2,94 \\
\hline P5 & 26 & 35 & 0,66 & Tela & $\mathrm{PES} / \mathrm{CO}$ & Urdume & 1000,00 & 110,35 & 0,23 & 0,1374 & 14,65 & 3,87 \\
\hline P5 & 26 & 35 & 0,66 & Tela & $\mathrm{PES} / \mathrm{CO}$ & Trama & 987,50 & 107,92 & 0,23 & 0,1428 & 15,82 & 2,67 \\
\hline$P 5$ & 26 & 35 & 0,66 & Tela & $\mathrm{PES} / \mathrm{CO}$ & Urdume & 855,00 & 107,92 & 0,23 & 0,1327 & 13,65 & 3,50 \\
\hline P5 & 26 & 35 & 0,66 & Tela & PES/CO & Trama & 1030,00 & 105,39 & 0,23 & 0,1439 & 16,07 & 3,07 \\
\hline P5 & 26 & 35 & 0,66 & Tela & $\mathrm{PES} / \mathrm{CO}$ & Urdume & 880,00 & 105,39 & 0,23 & 0,1307 & 13,25 & 2,59 \\
\hline P6 & 22 & 22 & 0,75 & Tela & WO/PES & Trama & 615,00 & 179,99 & 0,34 & 0,2412 & 45,11 & 1,10 \\
\hline P6 & 22 & 22 & 0,75 & Tela & WO/PES & Urdume & 570,00 & 179,99 & 0,34 & 0,2142 & 35,58 & 0,92 \\
\hline P6 & 22 & 22 & 0,73 & Tela & WO/PES & Trama & 555,00 & 179,42 & 0,35 & 0,2181 & 36,91 & 0,85 \\
\hline P6 & 22 & 22 & 0,73 & Tela & WO/PES & Urdume & 590,00 & 179,42 & 0,35 & 0,2191 & 37,23 & 1,07 \\
\hline
\end{tabular}




\begin{tabular}{|c|c|c|c|c|c|c|c|c|c|c|c|c|}
\hline P6 & 22 & 22 & 0,73 & Tela & WO/PES & Trama & 580,00 & 179,99 & 0,37 & 0,2239 & 38,87 & 1,04 \\
\hline P6 & 22 & 22 & 0,73 & Tela & WO/PES & Urdume & 605,00 & 179,99 & 0,37 & 0,2092 & 33,95 & 1,01 \\
\hline P6 & 22 & 22 & 0,72 & Tela & WO/PES & Trama & 530,00 & 181,53 & 0,37 & 0,2092 & 33,96 & 1,00 \\
\hline P6 & 22 & 22 & 0,72 & Tela & WO/PES & Urdume & 595,00 & 181,53 & 0,37 & 0,2200 & 37,54 & 0,93 \\
\hline P6 & 22 & 22 & 0,72 & Tela & WO/PES & Trama & 515,00 & 178,22 & 0,35 & 0,2183 & 36,96 & 1,07 \\
\hline P6 & 22 & 22 & 0,72 & Tela & WO/PES & Urdume & 535,00 & 178,22 & 0,35 & 0,2101 & 34,25 & 1,20 \\
\hline P6 & 22 & 22 & 0,72 & Tela & WO/PES & Trama & 605,00 & 179,59 & 0,37 & 0,2086 & 33,75 & 1,07 \\
\hline P6 & 22 & 22 & 0,72 & Tela & WO/PES & Urdume & 540,00 & 179,59 & 0,37 & 0,2191 & 37,23 & 0,87 \\
\hline P6 & 22 & 22 & 0,72 & Tela & WO/PES & Trama & 455,00 & 181,83 & 0,36 & 0,2099 & 34,17 & 0,75 \\
\hline P6 & 22 & 22 & 0,72 & Tela & WO/PES & Urdume & 535,00 & 181,83 & 0,36 & 0,2174 & 36,65 & 0,97 \\
\hline$P 6$ & 22 & 22 & 0,71 & Tela & WO/PES & Trama & 535,00 & 180,79 & 0,36 & 0,2209 & 37,85 & 1,02 \\
\hline$P 6$ & 22 & 22 & 0,71 & Tela & WO/PES & Urdume & 530,00 & 180,79 & 0,36 & 0,2025 & 31,80 & 0,95 \\
\hline P6 & 22 & 22 & 0,71 & Tela & WO/PES & Trama & 525,00 & 180,35 & 0,36 & 0,2079 & 33,54 & 0,87 \\
\hline P6 & 22 & 22 & 0,71 & Tela & WO/PES & Urdume & 565,00 & 180,35 & 0,36 & 0,2148 & 35,80 & 1,03 \\
\hline P6 & 22 & 22 & 0,71 & Tela & WO/PES & Trama & 575,00 & 177,91 & 0,37 & 0,2105 & 34,38 & 0,96 \\
\hline$P 6$ & 22 & 22 & 0,71 & Tela & WO/PES & Urdume & 495,00 & 177,91 & 0,37 & 0,2101 & 34,25 & 0,85 \\
\hline$P 7$ & 22 & 22 & 0,73 & Tela & WO/PES & Trama & 625,00 & 218,18 & 0,45 & 0,2191 & 37,23 & 0,84 \\
\hline$P 7$ & 22 & 22 & 0,73 & Tela & WO/PES & Urdume & 645,00 & 218,18 & 0,45 & 0,2168 & 36,45 & 1,05 \\
\hline$P 7$ & 22 & 22 & 0,73 & Tela & WO/PES & Trama & 645,00 & 223,15 & 0,44 & 0,2163 & 36,31 & 0,90 \\
\hline$P 7$ & 22 & 22 & 0,73 & Tela & WO/PES & Urdume & 635,00 & 223,15 & 0,44 & 0,2183 & 36,96 & 0,86 \\
\hline$P 7$ & 22 & 22 & 0,73 & Tela & WO/PES & Trama & 590,00 & 231,76 & 0,44 & 0,2173 & 36,62 & 0,67 \\
\hline P7 & 22 & 22 & 0,73 & Tela & WO/PES & Urdume & 590,00 & 231,76 & 0,44 & 0,2152 & 35,94 & 1,01 \\
\hline$P 7$ & 22 & 22 & 0,72 & Tela & WO/PES & Trama & 615,00 & 221,20 & 0,45 & 0,2191 & 37,23 & 0,52 \\
\hline$P 7$ & 22 & 22 & 0,72 & Tela & WO/PES & Urdume & 440,00 & 221,20 & 0,45 & 0,2118 & 34,78 & 0,86 \\
\hline$P 7$ & 22 & 22 & 0,72 & Tela & WO/PES & Trama & 640,00 & 233,21 & 0,47 & 0,2105 & 34,36 & 0,84 \\
\hline$P 7$ & 22 & 22 & 0,72 & Tela & WO/PES & Urdume & 525,00 & 233,21 & 0,47 & 0,2158 & 36,14 & 0,78 \\
\hline P7 & 22 & 22 & 0,72 & Tela & WO/PES & Trama & 570,00 & 223,48 & 0,43 & 0,2183 & 36,96 & 0,86 \\
\hline$P 7$ & 22 & 22 & 0,72 & Tela & WO/PES & Urdume & 555,00 & 223,48 & 0,43 & 0,2076 & 33,44 & 0,96 \\
\hline
\end{tabular}




\begin{tabular}{|c|c|c|c|c|c|c|c|c|c|c|c|c|}
\hline$P 7$ & 22 & 22 & 0,71 & Tela & WO/PES & Trama & 650,00 & 220,53 & 0,43 & 0,2079 & 33,54 & 0,53 \\
\hline$P 7$ & 22 & 22 & 0,71 & Tela & WO/PES & Urdume & 545,00 & 220,53 & 0,43 & 0,2134 & 35,31 & 0,98 \\
\hline$P 7$ & 22 & 22 & 0,71 & Tela & WO/PES & Trama & 505,00 & 230,06 & 0,43 & 0,2129 & 35,17 & 0,69 \\
\hline$P 7$ & 22 & 22 & 0,71 & Tela & WO/PES & Urdume & 535,00 & 230,06 & 0,43 & 0,2053 & 32,70 & 0,94 \\
\hline P7 & 22 & 22 & 0,71 & Tela & WO/PES & Trama & 570,00 & 223,87 & 0,43 & 0,2067 & 33,13 & 0,72 \\
\hline$P 7$ & 22 & 22 & 0,71 & Tela & WO/PES & Urdume & 585,00 & 223,87 & 0,43 & 0,2111 & 34,58 & 0,98 \\
\hline$P 7$ & 22 & 22 & 0,70 & Tela & WO/PES & Trama & 575,00 & 225,77 & 0,49 & 0,2120 & 34,86 & 0,87 \\
\hline P7 & 22 & 22 & 0,70 & Tela & WO/PES & Urdume & 565,00 & 225,77 & 0,49 & 0,2030 & 31,97 & 0,92 \\
\hline$P 8$ & 22 & 22 & 0,74 & Tela & WO/PES & Trama & 540,00 & 168,67 & 0,35 & 0,2351 & 42,86 & 1,05 \\
\hline$P 8$ & 22 & 22 & 0,74 & Tela & WO/PES & Urdume & 555,00 & 168,67 & 0,35 & 0,2127 & 35,09 & 1,04 \\
\hline$P 8$ & 22 & 22 & 0,74 & Tela & WO/PES & Trama & 520,00 & 170,20 & 0,35 & 0,2267 & 39,85 & 0,91 \\
\hline$P 8$ & 22 & 22 & 0,74 & Tela & WO/PES & Urdume & 570,00 & 170,20 & 0,35 & 0,2176 & 36,74 & 1,07 \\
\hline$P 8$ & 22 & 22 & 0,73 & Tela & WO/PES & Trama & 520,00 & 168,33 & 0,35 & 0,2138 & 35,45 & 0,96 \\
\hline$P 8$ & 22 & 22 & 0,73 & Tela & WO/PES & Urdume & 490,00 & 168,33 & 0,35 & 0,2269 & 39,92 & 1,03 \\
\hline$P 8$ & 22 & 22 & 0,73 & Tela & WO/PES & Trama & 460,00 & 171,93 & 0,35 & 0,2157 & 36,09 & 1,06 \\
\hline$P 8$ & 22 & 22 & 0,73 & Tela & WO/PES & Urdume & 580,00 & 171,93 & 0,35 & 0,2192 & 37,26 & 0,90 \\
\hline$P 8$ & 22 & 22 & 0,73 & Tela & WO/PES & Trama & 500,00 & 165,07 & 0,35 & 0,2208 & 37,83 & 0,90 \\
\hline$P 8$ & 22 & 22 & 0,73 & Tela & WO/PES & Urdume & 555,00 & 165,07 & 0,35 & 0,2138 & 35,47 & 1,06 \\
\hline$P 8$ & 22 & 22 & 0,72 & Tela & WO/PES & Trama & 460,00 & 166,43 & 0,36 & 0,2197 & 37,45 & 1,13 \\
\hline$P 8$ & 22 & 22 & 0,72 & Tela & WO/PES & Urdume & 535,00 & 166,43 & 0,36 & 0,2073 & 33,33 & 1,08 \\
\hline$P 8$ & 22 & 22 & 0,72 & Tela & WO/PES & Trama & 515,00 & 167,08 & 0,35 & 0,2108 & 34,46 & 0,83 \\
\hline$P 8$ & 22 & 22 & 0,72 & Tela & WO/PES & Urdume & 485,00 & 167,08 & 0,35 & 0,2142 & 35,61 & 1,12 \\
\hline$P 8$ & 22 & 22 & 0,71 & Tela & WO/PES & Trama & 580,00 & 167,09 & 0,34 & 0,2050 & 32,58 & 1,23 \\
\hline$P 8$ & 22 & 22 & 0,71 & Tela & WO/PES & Urdume & 580,00 & 167,09 & 0,34 & 0,2142 & 35,61 & 1,07 \\
\hline$P 8$ & 22 & 22 & 0,71 & Tela & WO/PES & Trama & 450,00 & 166,88 & 0,36 & 0,2073 & 33,33 & 0,94 \\
\hline$P 8$ & 22 & 22 & 0,71 & Tela & WO/PES & Urdume & 520,00 & 166,88 & 0,36 & 0,2120 & 34,85 & 1,14 \\
\hline$P 8$ & 22 & 22 & 0,71 & Tela & WO/PES & Trama & 530,00 & 168,75 & 0,34 & 0,1998 & 30,97 & 0,93 \\
\hline$P 8$ & 22 & 22 & 0,71 & Tela & WO/PES & Urdume & 610,00 & 168,75 & 0,34 & 0,2161 & 36,23 & 0,79 \\
\hline
\end{tabular}




\begin{tabular}{|c|c|c|c|c|c|c|c|c|c|c|c|c|}
\hline$T 1$ & 16 & 23 & 0,73 & Sarja & $\mathrm{CO}$ & Trama & 531,00 & 235,97 & 0,49 & 0,2761 & 59,13 & 0,92 \\
\hline$T 1$ & 16 & 23 & 0,73 & Sarja & $\mathrm{CO}$ & Urdume & 703,00 & 235,97 & 0,49 & 0,2236 & 38,79 & 0,89 \\
\hline$T 1$ & 16 & 23 & 0,73 & Sarja & $\mathrm{CO}$ & Trama & 464,00 & 235,09 & 0,50 & 0,2846 & 62,81 & 0,74 \\
\hline$T 1$ & 16 & 23 & 0,73 & Sarja & $\mathrm{CO}$ & Urdume & 710,00 & 235,09 & 0,50 & 0,2170 & 36,53 & 1,00 \\
\hline$T 1$ & 16 & 23 & 0,72 & Sarja & $\mathrm{CO}$ & Trama & 503,00 & 235,09 & 0,51 & 0,2797 & 60,69 & 0,89 \\
\hline$T 1$ & 16 & 23 & 0,72 & Sarja & $\mathrm{CO}$ & Urdume & 719,00 & 235,09 & 0,51 & 0,2142 & 35,60 & 0,98 \\
\hline$T 1$ & 16 & 23 & 0,72 & Sarja & $\mathrm{CO}$ & Trama & 518,00 & 235,09 & 0,50 & 0,2749 & 58,63 & 0,76 \\
\hline$T 1$ & 16 & 23 & 0,72 & Sarja & $\mathrm{CO}$ & Urdume & 690,00 & 235,09 & 0,50 & 0,2172 & 36,58 & 0,97 \\
\hline$T 1$ & 16 & 23 & 0,72 & Sarja & $\mathrm{CO}$ & Trama & 528,00 & 234,98 & 0,51 & 0,2788 & 60,31 & 0,93 \\
\hline$T 1$ & 16 & 23 & 0,72 & Sarja & $\mathrm{CO}$ & Urdume & 720,00 & 234,98 & 0,51 & 0,2126 & 35,06 & 0,92 \\
\hline$T 1$ & 16 & 23 & 0,72 & Sarja & $\mathrm{CO}$ & Trama & 509,00 & 234,08 & 0,49 & 0,2752 & 58,76 & 0,95 \\
\hline$T 1$ & 16 & 23 & 0,72 & Sarja & $\mathrm{CO}$ & Urdume & 699,00 & 234,08 & 0,49 & 0,2146 & 35,71 & 0,85 \\
\hline$T 1$ & 16 & 23 & 0,72 & Sarja & $\mathrm{CO}$ & Trama & 534,00 & 235,09 & 0,51 & 0,2802 & 60,91 & 1,05 \\
\hline$T 1$ & 16 & 23 & 0,72 & Sarja & $\mathrm{CO}$ & Urdume & 698,00 & 235,09 & 0,51 & 0,2107 & 34,44 & 0,82 \\
\hline$T 1$ & 16 & 23 & 0,71 & Sarja & $\mathrm{CO}$ & Trama & 536,00 & 234,08 & 0,51 & 0,2845 & 62,79 & 0,94 \\
\hline$T 1$ & 16 & 23 & 0,71 & Sarja & $\mathrm{CO}$ & Urdume & 683,00 & 234,08 & 0,51 & 0,2039 & 32,23 & 1,08 \\
\hline$T 1$ & 16 & 23 & 0,71 & Sarja & $\mathrm{CO}$ & Trama & 446,00 & 235,97 & 0,51 & 0,2793 & 60,49 & 0,90 \\
\hline$T 1$ & 16 & 23 & 0,71 & Sarja & $\mathrm{CO}$ & Urdume & 724,00 & 235,97 & 0,51 & 0,2058 & 32,84 & 0,81 \\
\hline$T 1$ & 16 & 23 & 0,71 & Sarja & $\mathrm{CO}$ & Trama & 453,00 & 234,98 & 0,51 & 0,2614 & 53,02 & 0,86 \\
\hline$T 1$ & 16 & 23 & 0,71 & Sarja & $\mathrm{CO}$ & Urdume & 708,00 & 234,98 & 0,51 & 0,2157 & 36,10 & 0,75 \\
\hline$T 2$ & 28 & 46 & 1,00 & Tela & $\mathrm{PES} / \mathrm{CO}$ & Urdume & 1070,00 & 103,04 & 0,20 & 0,2298 & 40,97 & 3,21 \\
\hline$T 2$ & 28 & 46 & 1,00 & Tela & $\mathrm{PES} / \mathrm{CO}$ & Trama & 1060,00 & 106,30 & 0,20 & 0,1252 & 12,16 & 2,79 \\
\hline$T 2$ & 28 & 46 & 1,00 & Tela & $\mathrm{PES} / \mathrm{CO}$ & Urdume & 1097,50 & 106,30 & 0,20 & 0,2225 & 38,42 & 2,75 \\
\hline$T 2$ & 28 & 46 & 1,00 & Tela & $\mathrm{PES} / \mathrm{CO}$ & Trama & 1082,50 & 104,46 & 0,20 & 0,1301 & 13,14 & 3,10 \\
\hline$T 2$ & 28 & 46 & 1,00 & Tela & $\mathrm{PES} / \mathrm{CO}$ & Urdume & 932,50 & 104,46 & 0,20 & 0,2224 & 38,37 & 2,73 \\
\hline$T 2$ & 28 & 46 & 1,00 & Tela & $\mathrm{PES} / \mathrm{CO}$ & Trama & 1007,50 & 103,55 & 0,20 & 0,1315 & 13,42 & 2,89 \\
\hline$T 2$ & 28 & 46 & 1,00 & Tela & $\mathrm{PES} / \mathrm{CO}$ & Urdume & 912,50 & 103,55 & 0,20 & 0,2217 & 38,13 & 3,42 \\
\hline$T 2$ & 28 & 46 & 1,00 & Tela & $\mathrm{PES} / \mathrm{CO}$ & Trama & 1027,50 & 106,30 & 0,20 & 0,1305 & 13,21 & 2,77 \\
\hline
\end{tabular}




\begin{tabular}{|c|c|c|c|c|c|c|c|c|c|c|c|c|}
\hline$T 2$ & 28 & 46 & 1,00 & Tela & $\mathrm{PES} / \mathrm{CO}$ & Urdume & 1065,00 & 106,30 & 0,20 & 0,2202 & 37,60 & 2,72 \\
\hline$T 2$ & 28 & 46 & 1,00 & Tela & $\mathrm{PES} / \mathrm{CO}$ & Trama & 1142,50 & 103,55 & 0,19 & 0,1256 & 12,24 & 3,02 \\
\hline$T 2$ & 28 & 46 & 1,00 & Tela & $\mathrm{PES} / \mathrm{CO}$ & Urdume & 910,00 & 103,55 & 0,19 & 0,2185 & 37,04 & 3,09 \\
\hline$T 2$ & 28 & 46 & 1,00 & Tela & $\mathrm{PES} / \mathrm{CO}$ & Trama & 1062,50 & 103,04 & 0,20 & 0,1305 & 13,21 & 2,66 \\
\hline$T 2$ & 28 & 46 & 1,00 & Tela & $\mathrm{PES} / \mathrm{CO}$ & Trama & 1042,50 & 103,66 & 0,20 & 0,1248 & 12,07 & 2,80 \\
\hline$T 2$ & 28 & 46 & 1,00 & Tela & $\mathrm{PES} / \mathrm{CO}$ & Urdume & 1020,00 & 103,66 & 0,20 & 0,2168 & 36,45 & 2,90 \\
\hline$T 2$ & 28 & 46 & 1,00 & Tela & $\mathrm{PES} / \mathrm{CO}$ & Trama & 1187,50 & 104,46 & 0,20 & 0,1245 & 12,02 & 2,98 \\
\hline$T 2$ & 28 & 46 & 1,00 & Tela & $\mathrm{PES} / \mathrm{CO}$ & Urdume & 1005,00 & 104,46 & 0,20 & 0,2164 & 36,31 & 2,81 \\
\hline$T 2$ & 28 & 46 & 0,98 & Tela & PES/CO & Trama & 1012,50 & 103,04 & 0,20 & 0,1307 & 13,26 & 2,79 \\
\hline$T 2$ & 28 & 46 & 0,98 & Tela & $\mathrm{PES} / \mathrm{CO}$ & Urdume & 950,00 & 103,04 & 0,20 & 0,2117 & 34,76 & 2,87 \\
\hline$T 2$ & 28 & 46 & 0,98 & Tela & PES/CO & Trama & 1070,00 & 103,66 & 0,19 & 0,1203 & 11,23 & 2,99 \\
\hline$T 2$ & 28 & 46 & 0,98 & Tela & $\mathrm{PES} / \mathrm{CO}$ & Urdume & 935,00 & 103,66 & 0,19 & 0,2095 & 34,04 & 2,71 \\
\hline
\end{tabular}

